\title{
ZOOTAXA
}

3660

\section{Revision of Nearctic Dasysyrphus Enderlein (Diptera: Syrphidae)}

\author{
MICHELLE M. LOCKE ${ }^{1,2,3} \&$ JEFFREY H. SKEVINGTON ${ }^{1,2}$
}

${ }^{I}$ Canadian National Collection of Insects, Arachnids and Nematodes, Agriculture and Agri-Food Canada, 960 Carling Avenue, Ottawa, ON K1A 0C6, Canada

Email:michellemlocke@gmail.com; jhskevington@gmail.com

${ }^{2}$ Department of Biology, 209 Nesbitt Building, Carleton University, 1125 Colonel By Drive, Ottawa, Ont., Canada K1S 5 B6

${ }^{3}$ Corresponding author

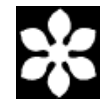

Magnolia Press

Auckland, New Zealand 
MICHELLE M. LOCKE \& JEFFREY H. SKEVINGTON

Revision of Nearctic Dasysyrphus Enderlein (Diptera: Syrphidae)

(Zootaxa 3660)

80 pp.; $30 \mathrm{~cm}$.

22 May 2013

ISBN 978-1-77557-174-2 (paperback)

ISBN 978-1-77557-175-9 (Online edition)

FIRST PUBLISHED IN 2013 BY

Magnolia Press

P.O. Box 41-383

Auckland 1346

New Zealand

e-mail: zootaxa@mapress.com

http://www.mapress.com/zootaxa/

(C) 2013 Magnolia Press
ISSN 1175-5326
(Print edition)
ISSN 1175-5334
(Online edition) 


\title{
Table of contents
}

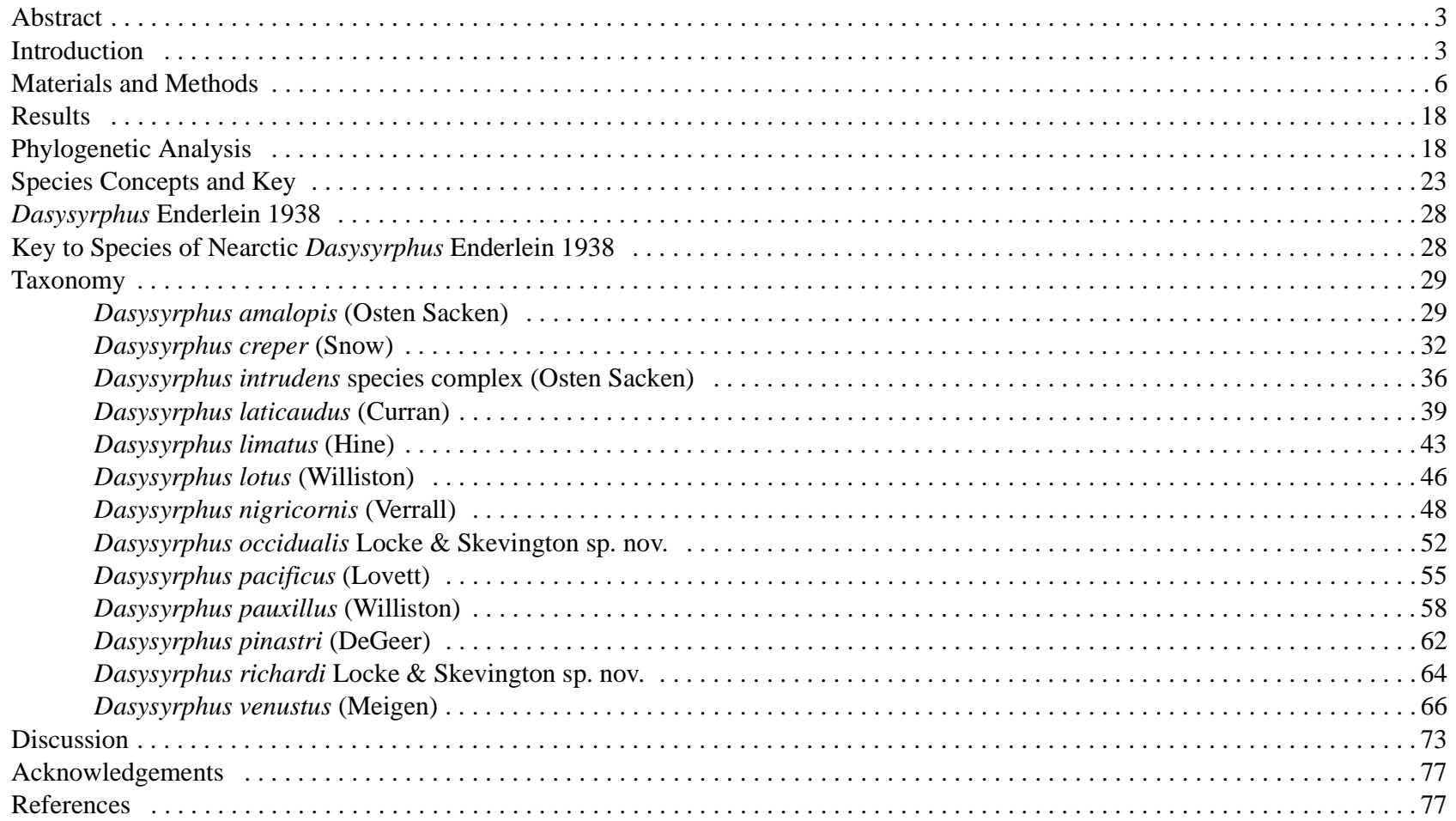

\begin{abstract}
Dasysyrphus Enderlein (Diptera: Syrphidae) has posed taxonomic challenges to researchers in the past, primarily due to their lack of interspecific diagnostic characters. In the present study, DNA data (mitochondrial cytochrome c oxidase subunit I-COI) were combined with morphology to help delimit species. This led to two species being resurrected from synonymy (D. laticaudus and D. pacificus) and the discovery of one new species (D. occidualis sp. nov.). An additional new species was described based on morphology alone (D. richardi sp. nov.), as the specimens were too old to obtain COI. Part of the taxonomic challenge presented by this group arises from missing type specimens. Neotypes are designated here for $D$. pauxillus and $D$. pinastri to bring stability to these names. An illustrated key to 13 Nearctic species is presented, along with descriptions, maps and supplementary data. A phylogeny based on COI is also presented and discussed.
\end{abstract}

Key words: Diptera, Syrphidae, Dasysyrphus, revision, flower flies, hover flies, key, new species, Nearctic Region

\section{Introduction}

Dasysyrphus Enderlein 1938 is mainly a Holarctic genus. Thirty-six of the 43 currently recognized species are known to occur in North America, Europe and Asia, with eight species recorded from the Oriental region and one species recorded from the Neotropical region (some species occur in more than one region; Pape \& Thompson 2010a). This is not an unusual distribution for a syrphine genus (Vockeroth 1969).

Little is known about the biology of Dasysyrphus. The majority of biological information we have comes from studies done in Europe. No larvae are known from endemic Nearctic species and as a result only adult ecology can be discussed. Much of what is known from the Nearctic and what will be discussed has been gathered from specimen label data.

Larvae are mottled, resemble bark and are easily recognized by a pair of long tapering projections on the anal segment, which help them to blend into their surroundings (Fig. 1A; Rotheray \& Gilbert 2011; Rotheray 1993). They are known to be arboreal in both coniferous and deciduous trees (Rotheray 1993). Larvae are predatory and feed mainly on homopterans, but records of them feeding on other insects have been noted. Rojo et al. (2003) provide a catalogue to Dasysyrphus species and their larval prey. Their review of the literature suggests that the 
larvae feed mainly on Aphididae, but have been found feeding on Adelgidae, Diptera larvae, Neuroptera, Lepidoptera, Hymenoptera and Coleoptera. Rojo et al. (2003) also recorded the plant associations of these Dasysyrphus larvae and their prey. Most studies found these larvae associated with trees of the families Pinaceae, Aceraceae, Ulmaceae, Fagaceae and Rosaceae. Some studies reported finding Dasysyrphus larvae on woody shrubs in the families Fabaceae, Rosaceae and Celastraceae and a few other studies reported finding them on herbaceous plants in the families Brassicaceae and Chenopodiaceae (Rojo et al. 2003). Goeldlin de Tiefenau (1974) reported that larvae he reared in the lab wrapped themselves around a stem and remained in one position to feed until ready to pupate. This position allowed them to block the path and intercept prey as they passed by.

Adults (Fig. 1B) are believed to be important pollinators. Their specific pollination habits are unknown but they are commonly found on flowers on sunny days. Most of the museum specimens observed have pollen grains stuck to their body hairs and in their gut. Adults have been recorded as visiting flowers of deciduous trees and smaller herbaceous plants (see Speight 2011). In the Nearctic region, specimens have been recorded as being collected from flowers of Prunus virginiana Linnaeus (Williston 1887) and Geranium Linnaeus (Snow 1895). While Dasysyrphus has been an understudied genus, a review of pollination in syrphids by Rotheray and Gilbert (2011) shows that the genera that have been studied are effective generalist pollinators. New data on flower visitation (from labels) is included in the species accounts below.

Dasysyrphus are imperfect mimics, not exactly resembling any specific hymenopteran, but having the black and yellow colouration common to many Hymenoptera. Rotheray and Gilbert (2011) and Penney et al. (2012) provide overviews and discuss some hypotheses as to why this imperfect mimicry may exist in syrphids. Since Dasysyrphus larvae tend to be arboreal, the adults are typically found in or near forests. Speight (2011) reports in his European species accounts that the following species are found in mainly coniferous, but sometimes deciduous forests: D. albostriatus (Fallen 1817), D. eggeri (Schiner 1861), D. friuliensis (Goot 1960), D. hilaris (Zetterstedt 1843), D. lenensis Bagatshanova 1980, D. pauxillus (Williston 1887), D. pinastri (De Geer 1776), D. postclaviger (Stys \& Moucha 1962), D. tricinctus (Fallen 1817) and D. venustus (Meigen 1822). Dasysyrphus nigricornis (Verrall 1873) is reported as being found in taiga (Neilsen 1998) and dwarf-shrub tundra, although much confusion exists over the name, so the full extent of its range and habitat are not known (Speight 2011).

Fluke (1933) was the first author to define what would later be called Dasysyrphus and he provided higher level and species keys with descriptions of all Nearctic species. He defined this group as the amalopis group under the genus Metasyrphus Matsumura (in Matsumura and Adachi) 1917. He stated that he was not prepared to associate his four distinct groups of Metasyrphus with existing genera due to the confusion of some of the generic concepts in the Old World and lack of material from the Old World to compare his specimens to.

Dasysyrphus was erected as a subgenus of Syrphus Fabricius 1775 in 1938 by Enderlein. The type species is $D$. albostriatus. Enderlein distinguished Dasysyrphus from the rest of the Syrphus group by the conspicuously dense hair on its eyes (a character now known to be shared with other syrphine genera). Dasysyrphus has a similar habitus to many other genera in the subfamily Syrphinae, having yellow spots or stripes on a black abdomen. Enderlein included 16 species in his new genus and described two more from the Palaearctic, Oriental and Afrotropical regions, although all seven species from the Oriental and Afrotropical regions and three from the Palaearctic have now been placed in other genera. Enderlein did not include any Nearctic species in Dasysyrphus. The Nearctic species were first placed in Dasysyrphus in 1965 when Stone et al. published "A Catalog of the Diptera of America North of Mexico". They referenced the Metasyrphus amalopis group of Fluke (1933) for the species that they included in Dasysyrphus. Vockeroth (1992) provided two keys to the seven Canadian, Alaskan and Greenlandic species of Dasysyrphus and species descriptions. No other recent revisionary work has been done. The first species of Dasysyrphus to be described was Musca pinastri De Geer 1776, from Europe. De Geer provided a description of the larvae and adults of this species and provided some ecological observations as well. De Geer was also one of the few authors to provide illustrations of the specimens he was describing. Forty-one additional species were described before Enderlein defined Dasysyrphus in 1938 and twenty-eight species have been erected since (including current synonyms; Pape \& Thompson 2010a). Previous to Dasysyrphus being erected, species of this genus were included in Syrphus, Musca Linnaeus 1758 and Scaeva Fabricius 1805 (Pape \& Thompson 2010a). Of the species found to occur in the Nearctic, Musca pinastri was the first to be described. In the Nearctic it is known to exist only in Greenland (Vockeroth 1992). Next, Syrphus venustus Meigen 1822 was described from Europe. In 1875, Osten Sacken described S. amalopis from the White Mountains in New Hampshire, making it the first species of what is now Dasysyrphus to be described from a specimen originating in 
continental North America. In 1877, Osten Sacken described S. intrudens from California and Williston described S. lotus and S. pauxillus from Arizona and New Mexico, respectively. Williston also included a key to the species of Syrphus in his paper. In 1895 Snow described two additional species, S. creper from Colorado and New Mexico, and $S$. disgregus, which is currently considered a synonym of D. venustus, from New Mexico. Lovett then described S. pacifica (in Cole \& Lovett 1919), presently a synonym of D. pauxillus, from Oregon. The species $S$. reflectipennis Curran 1921, was then described from Ontario. Syrphus limatus Hine 1922 was next described from Alaska. Curran (1925) later provided descriptions for three more species: S. laticaudus, S. osburni and S. laticaudatus. The former two species were described from Ontario, the latter from British Columbia.

Dasysyrphus is a poorly understood group taxonomically. Like many other genera in the tribe Syrphini it shows a narrow range of variation in characters among species but has a very distinctive habitus, so that Dasysyrphus is easily recognizable from other genera (Vockeroth 1969). This similarity in appearance among species has made defining species based on morphology difficult. There is no consensus as to which characters are variable and which are important in species characterization, which has led to very different species concepts. For the Nearctic, Fluke (1933) created his key to America north of Mexico (Canada and the USA), which treated 11 species. Vockeroth (1992) then created a key for his monograph on the Syrphinae of Canada, Alaska and Greenland. He synonymized some of the species Fluke had treated, leaving a total of seven species (six that Fluke had treated, plus pinastri, which was not included by Fluke). While Vockeroth's key does not formally treat the USA he does discuss the full extent of all of the species ranges, and he does discuss species occurring in the contiguous USA, not found in Canada. Keys to species in other regions include: Bartsch et al. (2009) for Nordic countries, Barkalov (2007) for the Asian region of Russia, Huo et al. (2005) for China, van Veen (2004) for Northwestern Europe, Stubbs \& Falk (2002) for Britain, Ghorpade (1994) for India and Peck (1974) for the Palaearctic. A manuscript for the Neotropical region is currently being written by Thompson (pers. comm.), which is why only Nearctic taxa, as opposed to all New World taxa, are revised here.

The majority of the problems with Dasysyrphus lie within the venustus and pauxillus groups. Taxa have been repeatedly split and lumped depending upon the criteria various authors considered important for species definition. Many of the species concepts do not include an in-depth description of characters or illustrations. As well, no in-depth studies have been conducted to compare Nearctic and Palaearctic specimens of hypothesized Holarctic taxa.

In the Nearctic, the most recent concept of D. venustus (Vockeroth 1992) included all of the specimens with abdominal maculae crossing the abdominal margin, excluding the well-defined D. limatus (based on the distinctive abdominal maculation pattern). Within this broad D. venustus concept there is extremely high variation in the pattern of the maculae, much more so than in any other species of Dasysyrphus. These maculae range from almost straight, with little medial constriction to lunulate and deeply constricted. With this much variation it is likely that multiple species exist.

Within the pauxillus group in the Nearctic there have been two other species described (D. laticaudus and $D$. pacificus), but currently they are both synonymized under pauxillus. Furthermore, the name pauxillus has been used throughout the Palaearctic to describe species occurring there. There are many Palaearctic species that have a similar habitus to pauxillus and their concepts are even more confused. This group needs to be carefully examined on a worldwide scale to fully understand the species boundaries.

As an independent source of information, molecular data may help to solve some of these issues. Molecular data have not been used before to attempt to untangle the species concepts of Nearctic Dasysyrphus. It has the potential to shed new light on these concepts and provide a new set of information to lend support to species concepts within Dasysyrphus. These data should also help to bridge the gap between Old World and New World research. Ongoing and unpublished morphological work by Doczkal (pers. comm.) and genetic work by Ståhls (pers. comm.) on the Palaearctic venustus group has illustrated new characters, and some new species. Doczkal has discovered subtle new characters and character systems that have never been applied to Dasysyrphus species before. His research was corroborated by Ståhls who sequenced COI (mitochondrial cytochrome c oxidase subunit I) and ITS2 (nuclear internal transcribed spacer region 2) for all of his putative species. Despite being unpublished, this Palaearctic research has helped form a ground plan for tackling the Nearctic species. Molecular data will also give us our first picture of the evolutionary relationships within Dasysyrphus.

With much uncertainty surrounding Nearctic Dasysyrphus, a species level revision is needed to sort out species boundaries in this genus. In the past, the interpretation of morphology has produced incongruent species concepts, 
largely due to perceived intraspecific variation and low interspecific variation. The following revision attempts to bring more data to bear on the problem and to describe each species in detail while painting a clearer picture of the boundaries of each species.

\section{Materials and Methods}

Specimens for this project were obtained from the following collections (arranged in alphabetical order by codon): Biodiversity Institute of Ontario, (BIOUG), Guelph, ON; California Academy of Sciences (CAS), San Francisco, CA; Canadian National Collection of Insects, Arachnids and Nematodes (CNC), Ottawa, ON; California State Collection of Arthropods (CSCA), Sacramento, CA; C.P. Gillette Museum of Arthropod Diversity, Colorado State University (CSUC), Fort Collins, CO; University of Guelph Insect Collection (DEBU), Guelph, ON; Essig Museum of Entomology, University of California Berkeley (EMEC), Berkeley, CA; Utah State University Insect Collection (EMUS), Logan, UT; Field Museum of Natural History (FMNH), Chicago, IL; Instituto Nacional de Biodiversidad (INBio), Santo Domingo de Heredia, Costa Rica; J.B. Wallis Museum of Entomology, University of Manitoba (JBWM), Winnipeg, MB; Lyman Entomological Museum, McGill University (LEMQ), Ste. Anne de Bellevue, QC; Museum of Comparative Zoology, Harvard University (MCZ), Cambridge, MA; Martin Hauser personal collection (MHPC); Albert J. Cook Arthropod Research Collection, Michigan State University (MSUC), East Lansing, MI; Oregon State University (OSAC), Corvallis, OR; C.A. Triplehorn Insect Collection, Ohio State University (OSU), Columbus, OH; Royal British Columbia Museum (RBCM), Victoria, BC; Royal Ontario Museum (ROME), Toronto, ON; Snow Entomological Museum, University of Kansas (SEMC), Lawrence, KS; Simon Fraser University (SFUC), Burnaby, BC; E.H. Strickland Entomological Museum, University of Alberta (UASM), Edmonton, AB; Spencer Museum, University of British Columbia (UBCZ), Vancouver, BC; United States National Museum of Natural History (USNM), Washington, DC; Eleanor Proctor personal collection (donated to CNC). Abbreviations for the collections are taken from Evenhuis (2012). Each specimen was given a unique identifying number (if one was not present from its home institution) and the label information was entered into the $\mathrm{CNC}$ specimen database. Most geocodes were inferred from label data.

To obtain DNA barcodes (658 base pairs from the $5^{\prime}$ end of COI), single legs were removed from selected specimens and were sent to the Biodiversity Institute of Ontario in Guelph, ON. There they extracted, amplified, purified and sequenced the DNA following protocols given by Hajibabaei et al. (2005). Some COI sequences were obtained at the Agriculture \& Agri-Food Canada, Eastern Cereal and Oilseed Research Centre Core Sequencing Facility (Ottawa, ON, Canada) (protocols below). DNA was extracted using a DNeasy® Tissue kit (Qiagen Inc., Santa Clara, CA, USA), using their Animal Tissue Spin-Column Protocol. Originally whole legs were used, however better results were obtained when the leg was ground up using the TissurRuptor (Qiagen Inc., Santa Clara, CA, USA).

COI was amplified in $25 \mathrm{~mL}$ reactions with $2.5 \mathrm{~mL} 10 \mathrm{X}$ ExTaq PCR buffer, $0.65 \mathrm{~mL} 25 \mathrm{mM} \mathrm{MgCl} 21 \mathrm{~mL}$ of each $10 \mathrm{mM}$ primer (one forward and one reverse), $2 \mathrm{~mL} 10 \mathrm{mM}$ dNTPs, $13.7 \mathrm{~mL} \mathrm{H}_{2} \mathrm{O}, 0.15 \mathrm{~mL}$ ExTaq HS DNA polymerase (Takara Bio USA, Madison, WI, USA), and $4 \mathrm{~mL}$ genomic DNA template. Different primers were used in an ongoing attempt to yield better results. The primers used were: LCO1490 (hebF; LCO1490 5'GGTCAACAAATCATAAAGATATTGG-3' (Folmer et al. 1994)), COI-Dipt-1858F (5'-GGNTGRCANGTNTAY CC-3' (Gibson et al. 2011)), HCO2198 (hebR; 5'-TAAACTTCAGGGTGACCAAAAAATCA-3' (Folmer $e t$ al. 1994)), K699R (5'-GGGGGTAAACTGTTCATCC-3' Wahlberg 2010) and COI-Dipt-2183R (5'-CCAAAAAATC ARAATARRTGYTG-3' (Gibson et al. 2011)). PCR amplification was performed on an Eppendorf ep Gradient S Mastercycler (Eppendorf AG, Hamburg, Germany). The amplification cycle used was $94^{\circ} \mathrm{C}$ for $3 \mathrm{~min}$.; $40 \mathrm{x}\left(94^{\circ} \mathrm{C}\right.$ for $1 \mathrm{~min}$.; $52^{\circ} \mathrm{C}$ for $1 \mathrm{~min}$.; $72^{\circ} \mathrm{C}$ for $1.5 \mathrm{~min}$.); $72^{\circ} \mathrm{C}$ for $5 \mathrm{~min}$. The PCR amplification products were run through $1 \%$ agarose electrophoresis gels for visual confirmation of PCR success. The PCR products were then purified in preparation for sequencing using ExoSAP-IT® protocol (USB Corp., Cleveland, OH, USA) or an E-Gel® Agarose Gel Electrophoresis System (Invitrogen ${ }^{\mathrm{TM}}$, Carlsbad, CA, USA) according to the protocol described in Gibson et al. (2010). Sequencing reactions were conducted using an ABI BigDye ${ }^{\circledR}$ Terminator v3.1 Cycle Sequencing kit (PE Applied Biosystems, Foster City, CA, USA). The reactions took place in a volume of $10 \mathrm{~mL}$, consisting of $1.5 \mathrm{~mL}$ BigDye ${ }^{\circledR}$ Terminator v1.1/3.1 Sequencing Buffer $(5 \mathrm{X}), 1 \mathrm{~mL}$ of Ready Reaction Mix (2.5X), $0.5 \mathrm{~mL} 10 \mathrm{mM}$ primer, $2 \mathrm{~mL} \mathrm{H}_{2} \mathrm{O}$ and $5 \mathrm{~mL}$ purified PCR product. Sequencing of the COI purified PCR product was performed at the 
Agriculture \& Agri-Food Canada, Eastern Cereal and Oilseed Research Centre Core Sequencing Facility (Ottawa, ON, Canada). Sequencing reactions were purified using the ABI ethanol/EDTA/sodium acetate precipitation protocol and analysed on an ABI 3130xl Genetic Analyzer (PE Applied Biosystems, Foster City, CA, USA). The resulting sequence chromatograms were edited and formed into contigs using Sequencher 4.7 (Gene Codes Corp., Ann Arbor, MI, USA). The contigs were examined in Mesquite version 2.73 (build 544; Maddison \& Maddison 2010) and aligned manually by the translated amino acid codons. The resultant sequences, as well as images and related data, can be accessed through the Barcode of Life Data Systems (BOLD; http://www.barcodinglife.org/) in the public project 'New World Dasysyrphus (NWDA)'. In addition, all sequences were deposited in GenBank (Table 1).

TABLE 1. Voucher information for Dasysyrphus species, including the geographc origin of the specimen, the institution storing the specimen, its unique voucher number and its GenBank number.

\begin{tabular}{|c|c|c|c|c|c|}
\hline Species & Country & State/Province & $\begin{array}{l}\text { Institution } \\
\text { Storing }\end{array}$ & Voucher Number & $\begin{array}{l}\text { GenBank } \\
\text { Number }\end{array}$ \\
\hline Dasysyrphus albostriatus & Germany & & FMNH & JSS 20734 & HQ974800 \\
\hline Dasysyrphus amalopis & Canada & Manitoba & BIOUG & 10PROBE-13673 & JF877350 \\
\hline Dasysyrphus amalopis & Canada & Manitoba & BIOUG & 10PROBE-13805 & JX827993 \\
\hline Dasysyrphus amalopis & Canada & Manitoba & BIOUG & 10PROBE-10909 & JF875437 \\
\hline Dasysyrphus amalopis & Canada & Manitoba & $\mathrm{CNC}$ & CNCD 9607 & JX828112 \\
\hline Dasysyrphus amalopis & Canada & Manitoba & BIOUG & 07PROBE-04723 & JX828010 \\
\hline Dasysyrphus amalopis & Canada & Yukon Territory & $\mathrm{CNC}$ & CNCD 13587 & JX828120 \\
\hline Dasysyrphus amalopis & Canada & Manitoba & BIOUG & 09PROBE-JW0176 & HM861391 \\
\hline Dasysyrphus amalopis & Canada & Manitoba & BIOUG & PROBE-TW0025 & JX828017 \\
\hline Dasysyrphus amalopis & Canada & Manitoba & BIOUG & 10PROBE-15042 & JX828085 \\
\hline Dasysyrphus amalopis & Canada & Manitoba & BIOUG & 10PROBE-14269 & JF877604 \\
\hline Dasysyrphus amalopis & Canada & Manitoba & BIOUG & 10PROBE-15283 & JX828041 \\
\hline Dasysyrphus bilineatus & South Korea & Kangwon-do & MHPC & JSS 20995 & HQ577441 \\
\hline Dasysyrphus bilineatus & South Korea & & MHPC & JSS 20997 & JX828021 \\
\hline Dasysyrphus bilineatus & Russia & Primorye & MHPC & JSS 21000 & HQ577443 \\
\hline Dasysyrphus bilineatus & South Korea & Kangwon-do & MHPC & JSS 20996 & HQ577442 \\
\hline Dasysyrphus creper & United States & California & MHPC & JSS 20950 & HQ577408 \\
\hline Dasysyrphus creper & Canada & British Columbia & $\mathrm{CNC}$ & JSS 18368 & GU708471 \\
\hline Dasysyrphus creper & United States & Wyoming & USNM & CNCD 5444 & JX828004 \\
\hline Dasysyrphus creper & Canada & Alberta & $\mathrm{CNC}$ & JSS 18293 & GU708511 \\
\hline Dasysyrphus creper & United States & California & MHPC & JSS 20956 & HQ577413 \\
\hline Dasysyrphus creper & United States & Arizona & USNM & USNM ENT 00258093 & JX828053 \\
\hline Dasysyrphus creper & United States & Arizona & CSUC & JSS 20683 & HQ974810 \\
\hline Dasysyrphus creper & United States & Colorado & CSUC & JSS 20684 & HQ974811 \\
\hline Dasysyrphus creper & United States & Colorado & CSUC & JSS 20685 & HQ974812 \\
\hline Dasysyrphus creper & United States & Wyoming & CSUC & JSS 20686 & HQ974813 \\
\hline Dasysyrphus creper & Canada & British Columbia & $\mathrm{RBCM}$ & RBCM ENT 988-5672 & JX828094 \\
\hline Dasysyrphus creper & United States & California & MHPC & JSS 20951 & HQ577409 \\
\hline Dasysyrphus creper & United States & Colorado & $\mathrm{CNC}$ & JSS 24626 & JX828011 \\
\hline Dasysyrphus creper & United States & California & MHPC & JSS 20962 & JX828042 \\
\hline Dasysyrphus creper & United States & California & MHPC & JSS 20955 & HQ577412 \\
\hline Dasysyrphus creper & United States & California & MHPC & JSS 20954 & HQ577411 \\
\hline
\end{tabular}

..... continued on the next page 
TABLE 1. (Continued)

\begin{tabular}{|c|c|c|c|c|c|}
\hline Species & Country & State/Province & $\begin{array}{l}\text { Institution } \\
\text { Storing }\end{array}$ & Voucher Number & $\begin{array}{l}\text { GenBank } \\
\text { Number }\end{array}$ \\
\hline Dasysyrphus creper & United States & Colorado & CSUC & JSS 20809 & JX828023 \\
\hline Dasysyrphus creper & United States & Utah & EMUS & JSS 24611 & JX828101 \\
\hline Dasysyrphus creper & Canada & British Columbia & $\mathrm{CNC}$ & CNCD 13631 & GU708512 \\
\hline Dasysyrphus creper & United States & Colorado & CSUC & JSS 20806 & HQ974824 \\
\hline Dasysyrphus creper & United States & Colorado & CSUC & JSS 20805 & JX828116 \\
\hline Dasysyrphus creper & United States & Colorado & CSUC & JSS 20682 & HQ974809 \\
\hline Dasysyrphus eggeri & Spain & Granada & USNM & USNM ENT 00258107 & HQ974714 \\
\hline Dasysyrphus intrudens sp. complex & United States & Alaska & $\mathrm{CNC}$ & JSS 18329 & GU708483 \\
\hline Dasysyrphus intrudens sp. complex & United States & Oregon & $\mathrm{CNC}$ & JSS 18330 & GU708484 \\
\hline Dasysyrphus intrudens sp. complex & Canada & Ontario & ROME & ROMEnt Spec. No. 98537 & JX827994 \\
\hline Dasysyrphus intrudens sp. complex & Canada & Quebec & $\mathrm{CNC}$ & JSS 18343 & GU708480 \\
\hline Dasysyrphus intrudens sp. complex & Canada & $\begin{array}{l}\text { Newfoundland and } \\
\text { Labrador }\end{array}$ & $\mathrm{CNC}$ & JSS 18344 & GU708481 \\
\hline Dasysyrphus intrudens sp. complex & Canada & Ontario & ROME & ROMEnt Spec. No. 98520 & JX828089 \\
\hline Dasysyrphus intrudens sp. complex & Canada & Alberta & $\mathrm{CNC}$ & JSS 18347 & GU708476 \\
\hline Dasysyrphus intrudens sp. complex & Canada & Ontario & ROME & ROMEnt Spec. No. 57891 & JX828095 \\
\hline Dasysyrphus intrudens sp. complex & Canada & Ontario & ROME & ROMEnt Spec. No. 74269 & JX828034 \\
\hline Dasysyrphus intrudens sp. complex & Canada & British Columbia & $\mathrm{CNC}$ & JSS 18372 & GU708472 \\
\hline Dasysyrphus intrudens sp. complex & Canada & Ontario & ROME & ROMEnt Spec. No. 98517 & JX828000 \\
\hline Dasysyrphus intrudens sp. complex & United States & Washington & USNM & USNM ENT 00258094 & GU708435 \\
\hline Dasysyrphus intrudens sp. complex & Canada & Ontario & ROME & ROMEnt Spec. No. 98529 & HQ577403 \\
\hline Dasysyrphus intrudens sp. complex & Canada & Ontario & ROME & ROMEnt Spec. No. 98538 & JX828113 \\
\hline Dasysyrphus intrudens sp. complex & Canada & Quebec & $\mathrm{CNC}$ & JSS 20800 & HQ577388 \\
\hline Dasysyrphus intrudens sp. complex & United States & Tennessee & $\mathrm{CNC}$ & JSS 20799 & HQ577387 \\
\hline Dasysyrphus intrudens sp. complex & United States & Tennessee & $\mathrm{CNC}$ & JSS 20798 & HQ577386 \\
\hline Dasysyrphus intrudens sp. complex & Canada & Quebec & CNC & JSS 20796 & HQ967233 \\
\hline Dasysyrphus intrudens sp. complex & Canada & Quebec & $\mathrm{CNC}$ & JSS 20794 & HQ577385 \\
\hline Dasysyrphus intrudens sp. complex & Canada & Quebec & $\mathrm{CNC}$ & JSS 20792 & JX828062 \\
\hline Dasysyrphus intrudens sp. complex & United States & California & $\mathrm{CNC}$ & JSS 20791 & HQ577384 \\
\hline Dasysyrphus intrudens sp. complex & Canada & British Columbia & SFUC & SFU 720561 & HQ577383 \\
\hline Dasysyrphus intrudens sp. complex & Canada & British Columbia & SFUC & SFU 717487 & HQ577382 \\
\hline Dasysyrphus intrudens sp. complex & Canada & British Columbia & SFUC & SFU 717389 & HQ577381 \\
\hline Dasysyrphus intrudens sp. complex & Canada & British Columbia & SFUC & SFU 717383 & HQ577380 \\
\hline Dasysyrphus intrudens sp. complex & United States & Arizona & USNM & CNCD 5461 & JX828110 \\
\hline Dasysyrphus intrudens sp. complex & United States & Washington & USNM & CNCD 5462 & JX828124 \\
\hline Dasysyrphus intrudens sp. complex & Canada & Yukon Territory & $\mathrm{CNC}$ & CNCD 5814 & JX828087 \\
\hline Dasysyrphus intrudens sp. complex & Canada & Yukon Territory & $\mathrm{CNC}$ & CNCD 5815 & JX827995 \\
\hline Dasysyrphus intrudens sp. complex & Canada & British Columbia & $\mathrm{CNC}$ & CNCD 5816 & JX828046 \\
\hline Dasysyrphus intrudens sp. complex & Canada & Alberta & $\mathrm{CNC}$ & CNCD 5818 & JX828050 \\
\hline Dasysyrphus intrudens sp. complex & Germany & $\begin{array}{l}\text { Baden- } \\
\text { Wuerttemberg }\end{array}$ & $\mathrm{CNC}$ & JSS 18299 & JX828088 \\
\hline Dasysyrphus intrudens sp. complex & Austria & Steiermark & $\mathrm{CNC}$ & JSS 18301 & JX828024 \\
\hline
\end{tabular}


TABLE 1. (Continued)

\begin{tabular}{|c|c|c|c|c|c|}
\hline Species & Country & State/Province & $\begin{array}{l}\text { Institution } \\
\text { Storing }\end{array}$ & Voucher Number & $\begin{array}{l}\text { GenBank } \\
\text { Number }\end{array}$ \\
\hline Dasysyrphus intrudens sp. complex & Canada & British Columbia & SFUC & SFU 717335 & HQ577379 \\
\hline Dasysyrphus intrudens sp. complex & Canada & British Columbia & SFUC & SFU 716998 & HQ577378 \\
\hline Dasysyrphus intrudens sp. complex & Canada & British Columbia & SFUC & SFU 716995 & HQ577377 \\
\hline Dasysyrphus intrudens sp. complex & United States & California & MHPC & JSS 20994 & HQ577440 \\
\hline Dasysyrphus intrudens sp. complex & United States & New Mexico & MHPC & JSS 20993 & JX828076 \\
\hline Dasysyrphus intrudens sp. complex & United States & California & MHPC & JSS 20991 & HQ967235 \\
\hline Dasysyrphus intrudens sp. complex & Canada & British Columbia & SFUC & SFU 716919 & HQ577376 \\
\hline Dasysyrphus intrudens sp. complex & Canada & British Columbia & SFUC & SFU 716878 & HQ577375 \\
\hline Dasysyrphus intrudens sp. complex & Canada & British Columbia & SFUC & SFU 716763 & HQ577374 \\
\hline Dasysyrphus intrudens sp. complex & Canada & Yukon Territory & $\mathrm{CNC}$ & CNCD 14030 & GU708504 \\
\hline Dasysyrphus intrudens sp. complex & Canada & Yukon Territory & $\mathrm{CNC}$ & CNCD 14033 & GU708499 \\
\hline Dasysyrphus intrudens sp. complex & Canada & Yukon Territory & $\mathrm{CNC}$ & CNCD 14034 & GU708500 \\
\hline Dasysyrphus intrudens sp. complex & Canada & British Columbia & $\mathrm{CNC}$ & CNCD 14312 & GU708497 \\
\hline Dasysyrphus intrudens sp. complex & Canada & British Columbia & SFUC & SFU 716544 & HQ577373 \\
\hline Dasysyrphus intrudens sp. complex & Canada & Ontario & $\mathrm{CNC}$ & CNCD 14568 & GU708498 \\
\hline Dasysyrphus intrudens sp. complex & Canada & Ontario & $\mathrm{CNC}$ & CNCD 14602 & GU708493 \\
\hline Dasysyrphus intrudens sp. complex & Canada & British Columbia & SFUC & SFU 716481 & HQ577372 \\
\hline Dasysyrphus intrudens sp. complex & Canada & British Columbia & SFUC & SFU 716181 & HQ577371 \\
\hline Dasysyrphus intrudens sp. complex & Canada & Quebec & $\mathrm{CNC}$ & CNCD 14633 & GU708496 \\
\hline Dasysyrphus intrudens sp. complex & Canada & Quebec & $\mathrm{CNC}$ & CNCD 14634 & GU708489 \\
\hline Dasysyrphus intrudens sp. complex & Canada & British Columbia & SFUC & SFU 716133 & HQ577370 \\
\hline Dasysyrphus intrudens sp. complex & Canada & Nova Scotia & $\mathrm{CNC}$ & CNCD 14772 & GU708491 \\
\hline Dasysyrphus intrudens sp. complex & Canada & British Columbia & SFUC & SFU 715931 & HQ577369 \\
\hline Dasysyrphus intrudens sp. complex & & & $\mathrm{RBCM}$ & JSS 20830 & JX828064 \\
\hline Dasysyrphus intrudens sp. complex & Russia & & $\mathrm{RBCM}$ & JSS 20829 & JN285982 \\
\hline Dasysyrphus intrudens sp. complex & Canada & British Columbia & $\mathrm{RBCM}$ & JSS 20826 & HQ974835 \\
\hline Dasysyrphus intrudens sp. complex & Canada & Alberta & $\mathrm{RBCM}$ & RBCM ENT 006-006034 & HQ974834 \\
\hline Dasysyrphus intrudens sp. complex & Canada & British Columbia & $\mathrm{RBCM}$ & JSS 20823 & HQ974833 \\
\hline Dasysyrphus intrudens sp. complex & Canada & Yukon Territory & $\mathrm{RBCM}$ & JSS 20821 & HQ974832 \\
\hline Dasysyrphus intrudens sp. complex & Canada & British Columbia & SFUC & SFU 715868 & HQ577368 \\
\hline Dasysyrphus intrudens sp. complex & Canada & British Columbia & SFUC & SFU 715565 & HQ577367 \\
\hline Dasysyrphus intrudens sp. complex & Canada & Yukon Territory & $\mathrm{RBCM}$ & JSS 20818 & HQ974830 \\
\hline Dasysyrphus intrudens sp. complex & Canada & Yukon Territory & $\mathrm{RBCM}$ & JSS 20817 & HQ974829 \\
\hline Dasysyrphus intrudens sp. complex & Canada & British Columbia & SFUC & SFU 715497 & HQ577366 \\
\hline Dasysyrphus intrudens sp. complex & Canada & Quebec & $\mathrm{CNC}$ & CNCD 30878 & HQ577365 \\
\hline Dasysyrphus intrudens sp. complex & Canada & Quebec & $\mathrm{CNC}$ & CNCD 30877 & HQ577364 \\
\hline Dasysyrphus intrudens sp. complex & Canada & British Columbia & $\mathrm{CNC}$ & CNCD 30911 & HQ577363 \\
\hline Dasysyrphus intrudens sp. complex & Canada & British Columbia & $\mathrm{CNC}$ & CNCD 30910 & HQ577362 \\
\hline Dasysyrphus intrudens sp. complex & United States & Washington & CSUC & JSS 20803 & HQ974822 \\
\hline Dasysyrphus intrudens sp. complex & Canada & British Columbia & $\mathrm{CNC}$ & CNCD 30907 & HQ577359 \\
\hline Dasysyrphus intrudens sp. complex & Canada & British Columbia & $\mathrm{CNC}$ & CNCD 30905 & HQ577357 \\
\hline
\end{tabular}


TABLE 1. (Continued)

\begin{tabular}{|c|c|c|c|c|c|}
\hline Species & Country & State/Province & $\begin{array}{l}\text { Institution } \\
\text { Storing }\end{array}$ & Voucher Number & $\begin{array}{l}\text { GenBank } \\
\text { Number }\end{array}$ \\
\hline Dasysyrphus intrudens sp. complex & Canada & British Columbia & $\mathrm{CNC}$ & CNCD 30904 & HQ577356 \\
\hline Dasysyrphus intrudens sp. complex & United States & Alaska & $\mathrm{CNC}$ & CNCD 30901 & HQ577353 \\
\hline Dasysyrphus intrudens sp. complex & United States & Colorado & CSUC & JSS 20691 & HQ974817 \\
\hline Dasysyrphus intrudens sp. complex & United States & Washington & CSUC & JSS 20690 & HQ974816 \\
\hline Dasysyrphus intrudens sp. complex & United States & Washington & CSUC & JSS 20689 & JN285981 \\
\hline Dasysyrphus intrudens sp. complex & United States & Colorado & CSUC & JSS 20688 & HQ974815 \\
\hline Dasysyrphus intrudens sp. complex & United States & Colorado & CSUC & JSS 20687 & HQ974814 \\
\hline Dasysyrphus intrudens sp. complex & United States & Alaska & $\mathrm{CNC}$ & CNCD 30900 & HQ577352 \\
\hline Dasysyrphus intrudens sp. complex & Canada & British Columbia & UBCZ & JSS 20744 & HQ974807 \\
\hline Dasysyrphus intrudens sp. complex & United States & Alaska & $\mathrm{CNC}$ & CNCD 30894 & HQ577349 \\
\hline Dasysyrphus intrudens sp. complex & United States & Alaska & $\mathrm{CNC}$ & CNCD 30892 & HQ577347 \\
\hline Dasysyrphus intrudens sp. complex & United States & Alaska & $\mathrm{CNC}$ & CNCD 30891 & HQ577346 \\
\hline Dasysyrphus intrudens sp. complex & United States & Alaska & $\mathrm{CNC}$ & CNCD 30880 & HQ577338 \\
\hline Dasysyrphus intrudens sp. complex & Canada & Manitoba & BIOUG & 09PROBE-JW0140 & HM861356 \\
\hline Dasysyrphus intrudens sp. complex & United States & Alaska & $\mathrm{CNC}$ & CNCD 30879 & HQ577337 \\
\hline Dasysyrphus intrudens sp. complex & Canada & Yukon Territory & $\mathrm{CNC}$ & CNC DIPTERA 14028 & JX828106 \\
\hline Dasysyrphus intrudens sp. complex & Canada & Yukon Territory & $\mathrm{CNC}$ & CNC DIPTERA 14027 & JX828122 \\
\hline Dasysyrphus intrudens sp. complex & Canada & Yukon Territory & $\mathrm{CNC}$ & CNC DIPTERA 14035 & JX828091 \\
\hline Dasysyrphus intrudens sp. complex & United States & Colorado & $\mathrm{CNC}$ & CNCD 5441 & JX828057 \\
\hline Dasysyrphus intrudens sp. complex & Canada & Quebec & $\mathrm{CNC}$ & JSS 19738 & HQ974843 \\
\hline Dasysyrphus intrudens sp. complex & Norway & & $\mathrm{CNC}$ & CNCD 35316 & JX828047 \\
\hline Dasysyrphus intrudens sp. complex & United States & California & $\mathrm{CNC}$ & JSS 19706 & HQ974859 \\
\hline Dasysyrphus intrudens sp. complex & Canada & British Columbia & UASM & UASM 141937 & HQ974799 \\
\hline Dasysyrphus intrudens sp. complex & United States & Washington & LEMQ & JSS 20738 & JX828014 \\
\hline Dasysyrphus intrudens sp. complex & Canada & Yukon Territory & LEMQ & LEM 0014304 & HQ974802 \\
\hline Dasysyrphus intrudens sp. complex & United States & Washington & DEBU & JSS 24638 & JX828069 \\
\hline Dasysyrphus intrudens sp. complex & United States & Washington & LEMQ & JSS 20740 & HQ974803 \\
\hline Dasysyrphus intrudens sp. complex & Canada & Yukon Territory & LEMQ & LEM 0014302 & HQ974804 \\
\hline Dasysyrphus intrudens sp. complex & Canada & Yukon Territory & LEMQ & LEM 0014466 & HQ974805 \\
\hline Dasysyrphus intrudens sp. complex & Canada & Yukon Territory & LEMQ & LEM 0014469 & HQ974806 \\
\hline Dasysyrphus intrudens sp. complex & United States & Oregon & DEBU & JSS 24641 & JX828040 \\
\hline Dasysyrphus intrudens sp. complex & United States & Washington & $\mathrm{CNC}$ & JSS 24640 & JX828099 \\
\hline Dasysyrphus intrudens sp. complex & United States & Colorado & $\mathrm{CNC}$ & JSS 24637 & JX828092 \\
\hline Dasysyrphus intrudens sp. complex & Canada & Ontario & $\mathrm{CNC}$ & JSS 24634 & JX828019 \\
\hline Dasysyrphus intrudens sp. complex & United States & Utah & EMUS & JSS 24633 & JX828107 \\
\hline Dasysyrphus intrudens sp. complex & United States & Utah & EMUS & JSS 24632 & JX828079 \\
\hline Dasysyrphus intrudens sp. complex & United States & Utah & EMUS & JSS 24631 & JX828016 \\
\hline Dasysyrphus intrudens sp. complex & United States & Washington & $\mathrm{CNC}$ & JSS 24627 & JX828074 \\
\hline Dasysyrphus intrudens sp. complex & United States & California & MHPC & JSS 20990 & HQ577438 \\
\hline Dasysyrphus intrudens sp. complex & Canada & Ontario & $\mathrm{CNC}$ & JSS 24624 & JX828103 \\
\hline Dasysyrphus intrudens sp. complex & United States & Washington & DEBU & JSS 24623 & JX828082 \\
\hline
\end{tabular}


TABLE 1. (Continued)

\begin{tabular}{|c|c|c|c|c|c|}
\hline Species & Country & State/Province & $\begin{array}{l}\text { Institution } \\
\text { Storing }\end{array}$ & Voucher Number & $\begin{array}{l}\text { GenBank } \\
\text { Number }\end{array}$ \\
\hline Dasysyrphus intrudens sp. complex & United States & Washington & $\mathrm{CNC}$ & JSS 24622 & JX828015 \\
\hline Dasysyrphus intrudens sp. complex & United States & Colorado & DEBU & JSS 24621 & JX828104 \\
\hline Dasysyrphus intrudens sp. complex & Canada & Quebec & $\mathrm{CNC}$ & JSS 24620 & JX828118 \\
\hline Dasysyrphus intrudens sp. complex & United States & Utah & EMUS & JSS 24619 & JX828002 \\
\hline Dasysyrphus intrudens sp. complex & United States & New Mexico & MHPC & JSS 20989 & JX828084 \\
\hline Dasysyrphus intrudens sp. complex & United States & California & MHPC & JSS 20973 & HQ577429 \\
\hline Dasysyrphus intrudens sp. complex & United States & California & MHPC & JSS 20965 & HQ577421 \\
\hline Dasysyrphus intrudens sp. complex & United States & California & MHPC & JSS 20964 & HQ577420 \\
\hline Dasysyrphus intrudens sp. complex & Canada & Alberta & UASM & JSS 21072 & HQ577451 \\
\hline Dasysyrphus intrudens sp. complex & United States & California & MHPC & JSS 20961 & HQ577418 \\
\hline Dasysyrphus intrudens sp. complex & United States & Washington & $\mathrm{CNC}$ & JSS 23707 & JX828081 \\
\hline Dasysyrphus intrudens sp. complex & United States & California & MHPC & JSS 20960 & HQ577417 \\
\hline Dasysyrphus intrudens sp. complex & United States & Colorado & DEBU & JSS 23704 & JX828065 \\
\hline Dasysyrphus intrudens sp. complex & United States & Colorado & $\mathrm{CNC}$ & JSS 23702 & JX828008 \\
\hline Dasysyrphus intrudens sp. complex & United States & California & MHPC & JSS 20959 & HQ577416 \\
\hline Dasysyrphus intrudens sp. complex & United States & California & MHPC & JSS 20953 & JX828111 \\
\hline Dasysyrphus intrudens sp. complex & Canada & Ontario & $\mathrm{MCZ}$ & JSS 21360 & JX828007 \\
\hline Dasysyrphus intrudens sp. complex & United States & California & MHPC & JSS 20952 & HQ577410 \\
\hline Dasysyrphus intrudens sp. complex & Canada & Quebec & $\mathrm{CNC}$ & JSS 15331 & GU708488 \\
\hline Dasysyrphus intrudens sp. complex & Canada & Quebec & $\mathrm{CNC}$ & JSS 17748 & GU708482 \\
\hline Dasysyrphus laticaudus & Canada & Ontario & $\mathrm{MCZ}$ & JSS 21355 & JX828102 \\
\hline Dasysyrphus laticaudus & Canada & Ontario & $\mathrm{CNC}$ & JSS 24614 & JX828105 \\
\hline Dasysyrphus laticaudus & Canada & Ontario & $\mathrm{CNC}$ & JSS 24613 & JX828029 \\
\hline Dasysyrphus laticaudus & Canada & Ontario & $\mathrm{MCZ}$ & JSS 21356 & JX828026 \\
\hline Dasysyrphus laticaudus & Canada & Quebec & $\mathrm{CNC}$ & JSS 18342 & JX828054 \\
\hline Dasysyrphus laticaudus & Canada & Yukon Territory & $\mathrm{CNC}$ & JSS 18373 & GU708473 \\
\hline Dasysyrphus laticaudus & Canada & Ontario & $\mathrm{CNC}$ & CNCD 13858 & GU708505 \\
\hline Dasysyrphus laticaudus & Canada & New Brunswick & CNC & CNCD 13898 & GU708507 \\
\hline Dasysyrphus laticaudus & Canada & Quebec & $\mathrm{CNC}$ & JSS 17647 & GU708501 \\
\hline Dasysyrphus laticaudus & Canada & Ontario & $\mathrm{CNC}$ & CNCD 30883 & JX828043 \\
\hline Dasysyrphus laticaudus & Canada & Ontario & $\mathrm{CNC}$ & JSS 19761 & HQ974860 \\
\hline Dasysyrphus laticaudus & Canada & Quebec & $\mathrm{CNC}$ & JSS 17665 & HQ974849 \\
\hline Dasysyrphus laticaudus & Canada & Quebec & $\mathrm{CNC}$ & JSS 17664 & HQ974848 \\
\hline Dasysyrphus laticaudus & Canada & Quebec & $\mathrm{CNC}$ & JSS 17663 & HQ974847 \\
\hline Dasysyrphus laticaudus & Canada & Quebec & $\mathrm{CNC}$ & JSS 17662 & HQ974846 \\
\hline Dasysyrphus laticaudus & Canada & Ontario & $\mathrm{CNC}$ & CNCD 30882 & HQ577340 \\
\hline Dasysyrphus laticaudus & Canada & Ontario & $\mathrm{CNC}$ & CNCD 30885 & HQ577341 \\
\hline Dasysyrphus laticaudus & Canada & Ontario & $\mathrm{CNC}$ & CNCD 30887 & HQ577342 \\
\hline Dasysyrphus laticaudus & Canada & Ontario & $\mathrm{CNC}$ & JSS 19757 & HQ577389 \\
\hline Dasysyrphus laticaudus & Canada & Ontario & ROME & ROMEnt Spec. No. 98519 & HQ577393 \\
\hline Dasysyrphus laticaudus & Canada & Ontario & ROME & ROMEnt Spec. No. 98518 & JX828025 \\
\hline
\end{tabular}


TABLE 1. (Continued)

\begin{tabular}{|c|c|c|c|c|c|}
\hline Species & Country & State/Province & $\begin{array}{l}\text { Institution } \\
\text { Storing }\end{array}$ & Voucher Number & $\begin{array}{l}\text { GenBank } \\
\text { Number }\end{array}$ \\
\hline Dasysyrphus lenensis & Germany & Niedersachsen & FMNH & JSS 20737 & HQ974801 \\
\hline Dasysyrphus limatus & United States & Utah & EMUS & JSS 24607 & JX828063 \\
\hline Dasysyrphus limatus & Canada & Yukon Territory & $\mathrm{CNC}$ & CNC DIPTERA 13691 & JX828031 \\
\hline Dasysyrphus limatus & Canada & Yukon Territory & $\mathrm{CNC}$ & CNCD 13685 & JX828055 \\
\hline Dasysyrphus limatus & Canada & Yukon Territory & $\mathrm{CNC}$ & CNC DIPTERA 13677 & JX828097 \\
\hline Dasysyrphus limatus & Canada & Yukon Territory & $\mathrm{CNC}$ & CNC DIPTERA 13676 & JX828073 \\
\hline Dasysyrphus limatus & Canada & Quebec & $\mathrm{CNC}$ & JSS 20795 & JX828030 \\
\hline Dasysyrphus lotus & United States & Arizona & $\mathrm{CNC}$ & CNCD 26394 & JX828100 \\
\hline Dasysyrphus lotus & United States & Arizona & $\mathrm{CNC}$ & JSS 18303 & JX828038 \\
\hline Dasysyrphus lotus & Colombia & Magdalena & USNM & USNM ENT 00035113 & HM432620 \\
\hline Dasysyrphus nigricornis & Canada & Manitoba & CNC & CNCD 9206 & JX828037 \\
\hline Dasysyrphus nigricornis & Canada & Manitoba & $\mathrm{CNC}$ & CNCD 9274 & JX828078 \\
\hline Dasysyrphus nigricornis & & & $\mathrm{RBCM}$ & JSS 20831 & JX828096 \\
\hline Dasysyrphus nigricornis & Canada & $\begin{array}{l}\text { Northwest } \\
\text { Territories }\end{array}$ & $\mathrm{CNC}$ & CNCD 13772 & GU708508 \\
\hline Dasysyrphus nigricornis & United States & Alaska & $\mathrm{CNC}$ & CNCD 30896 & JX828114 \\
\hline Dasysyrphus nigricornis & Canada & Manitoba & $\mathrm{CNC}$ & CNCD 9204 & JX828035 \\
\hline Dasysyrphus nigricornis & Canada & Manitoba & $\mathrm{CNC}$ & CNCD 9205 & JX828012 \\
\hline Dasysyrphus pacificus & United States & California & MHPC & JSS 20974 & HQ577430 \\
\hline Dasysyrphus pacificus & United States & California & MHPC & JSS 20972 & HQ577428 \\
\hline Dasysyrphus pacificus & United States & Washington & $\mathrm{CNC}$ & CNCD 35313 & JX828083 \\
\hline Dasysyrphus pacificus & United States & California & MHPC & JSS 20978 & HQ577434 \\
\hline Dasysyrphus pacificus & United States & California & MHPC & JSS 20971 & HQ577427 \\
\hline Dasysyrphus pacificus & United States & California & MHPC & JSS 20970 & HQ577426 \\
\hline Dasysyrphus pacificus & United States & California & MHPC & JSS 20969 & HQ577425 \\
\hline Dasysyrphus pacificus & United States & California & MHPC & JSS 20968 & HQ577424 \\
\hline Dasysyrphus pacificus & United States & California & MHPC & JSS 20967 & HQ577423 \\
\hline Dasysyrphus pacificus & United States & California & MHPC & JSS 20966 & HQ577422 \\
\hline Dasysyrphus pacificus & United States & California & MHPC & JSS 20963 & HQ577419 \\
\hline Dasysyrphus pacificus & United States & California & MHPC & JSS 20979 & HQ577435 \\
\hline Dasysyrphus pacificus & United States & California & MHPC & JSS 20958 & HQ577415 \\
\hline Dasysyrphus pacificus & United States & California & MHPC & JSS 20980 & HQ577436 \\
\hline Dasysyrphus pacificus & United States & Washington & $\mathrm{CNC}$ & CNCD 35314 & JX828121 \\
\hline Dasysyrphus pacificus & United States & California & MHPC & JSS 20992 & HQ577439 \\
\hline Dasysyrphus pacificus & United States & California & MHPC & JSS 20957 & HQ577414 \\
\hline Dasysyrphus pacificus & United States & Oregon & USNM & CNCD 5457 & JX828013 \\
\hline Dasysyrphus pacificus & United States & California & CNC & JSS 20797 & JX828067 \\
\hline Dasysyrphus pacificus & United States & California & MHPC & JSS 20977 & HQ577433 \\
\hline Dasysyrphus pacificus & United States & California & MHPC & JSS 20976 & HQ577432 \\
\hline Dasysyrphus pacificus & United States & California & MHPC & JSS 20975 & HQ577431 \\
\hline Dasysyrphus pauxillus & United States & Colorado & CSUC & JSS 20808 & HQ974826 \\
\hline Dasysyrphus pauxillus & Canada & Manitoba & BIOUG & 09PROBE-JW0197 & HM861412 \\
\hline
\end{tabular}


TABLE 1. (Continued)

\begin{tabular}{|c|c|c|c|c|c|}
\hline Species & Country & State/Province & $\begin{array}{l}\text { Institution } \\
\text { Storing }\end{array}$ & Voucher Number & $\begin{array}{l}\text { GenBank } \\
\text { Number }\end{array}$ \\
\hline Dasysyrphus pauxillus & Canada & Manitoba & BIOUG & 10PROBE-10249 & JF874884 \\
\hline Dasysyrphus pauxillus & Canada & Manitoba & BIOUG & 09PROBE-JW0255 & HM861468 \\
\hline Dasysyrphus pauxillus & United States & Colorado & CSUC & JSS 20693 & HQ974819 \\
\hline Dasysyrphus pauxillus & United States & Colorado & CSUC & JSS 20694 & HQ974820 \\
\hline Dasysyrphus pauxillus & Canada & British Columbia & $\mathrm{CNC}$ & CNCD 30906 & HQ577358 \\
\hline Dasysyrphus pauxillus & United States & Colorado & CSUC & JSS 20810 & HQ974827 \\
\hline Dasysyrphus pauxillus & United States & Colorado & FMNH & JSS 20814 & HQ974828 \\
\hline Dasysyrphus pauxillus & Canada & Manitoba & $\mathrm{CNC}$ & CNCD 9198 & JX828052 \\
\hline Dasysyrphus pauxillus & Canada & Alberta & $\mathrm{CNC}$ & JSS 20801 & HQ967234 \\
\hline Dasysyrphus pauxillus & United States & New Mexico & $\mathrm{CNC}$ & JSS 18346 & GU708475 \\
\hline Dasysyrphus pauxillus & Canada & British Columbia & $\mathrm{CNC}$ & CNCD 7969 & GU708492 \\
\hline Dasysyrphus pauxillus & United States & Utah & $\mathrm{CNC}$ & JSS 24615 & JX828045 \\
\hline Dasysyrphus pauxillus & United States & Utah & $\mathrm{CNC}$ & JSS 24616 & JX828032 \\
\hline Dasysyrphus pauxillus & United States & Utah & EMUS & JSS 24617 & JX828061 \\
\hline Dasysyrphus pauxillus & United States & Colorado & $\mathrm{CNC}$ & JSS 24618 & JX828077 \\
\hline Dasysyrphus pauxillus & United States & Colorado & $\mathrm{CNC}$ & CNCD 35312 & JX828006 \\
\hline Dasysyrphus pinastri & Sweden & Vasterbotten & $\mathrm{CNC}$ & CNCD 26454 & JX828108 \\
\hline Dasysyrphus pinastri & Sweden & Vasterbotten & $\mathrm{CNC}$ & JSS 18310 & JX828098 \\
\hline Dasysyrphus Sp. 19 & Costa Rica & San Jose & USNM & USNM ENT 00033245 & HQ974713 \\
\hline Dasysyrphus Sp. 19 & Costa Rica & & USNM & USNM ENT 00035102 & GU708438 \\
\hline Dasysyrphus Sp. 19 & Costa Rica & & $\mathrm{CNC}$ & JSS 18356 & GU708478 \\
\hline Dasysyrphus Sp. 19 & Costa Rica & & $\mathrm{CNC}$ & JSS 18351 & GU708477 \\
\hline Dasysyrphus Sp. 23 & South Korea & Kangwon-do & MHPC & JSS 21067 & HQ577450 \\
\hline Dasysyrphus occidualis & United States & Washington & CNC & CNCD 35311 & JX828058 \\
\hline Dasysyrphus occidualis & Canada & Yukon Territory & $\mathrm{RBCM}$ & JSS 20820 & HQ974831 \\
\hline Dasysyrphus occidualis & United States & Washington & CSUC & JSS 20681 & HQ974808 \\
\hline Dasysyrphus occidualis & Canada & Yukon Territory & $\mathrm{RBCM}$ & JSS 20819 & JX828068 \\
\hline Dasysyrphus occidualis & United States & Washington & DEBU & JSS 23706 & JX828033 \\
\hline Dasysyrphus occidualis & United States & Washington & $\mathrm{CNC}$ & JSS 23708 & JX828059 \\
\hline Dasysyrphus occidualis & United States & Alaska & $\mathrm{CNC}$ & CNCD 30899 & HQ577351 \\
\hline Dasysyrphus occidualis & United States & Washington & CSUC & JSS 20804 & HQ974823 \\
\hline Dasysyrphus occidualis & Canada & British Columbia & $\mathrm{CNC}$ & CNCD 30909 & HQ577361 \\
\hline Dasysyrphus occidualis & United States & Washington & DEBU & JSS 24625 & JX828022 \\
\hline Dasysyrphus occidualis & Canada & British Columbia & $\mathrm{CNC}$ & CNCD 30903 & HQ577355 \\
\hline Dasysyrphus occidualis & Canada & British Columbia & $\mathrm{CNC}$ & CNCD 30908 & HQ577360 \\
\hline Dasysyrphus tricinctus & South Korea & Kangwon-do & MHPC & JSS 21015 & JX828048 \\
\hline Dasysyrphus tricinctus & Sweden & Vasterbotten & $\mathrm{CNC}$ & JSS 18315 & GU708502 \\
\hline Dasysyrphus tricinctus & Poland & & USNM & CNCD 5459 & JX828003 \\
\hline Dasysyrphus venustus & Canada & Ontario & ROME & ROMEnt Spec. No. 57889 & JX828060 \\
\hline Dasysyrphus venustus & Canada & Ontario & ROME & ROMEnt Spec. No. 57888 & JX828093 \\
\hline Dasysyrphus venustus & United States & Pennsylvania & USNM & USNM ENT 00258081 & GU708437 \\
\hline
\end{tabular}


TABLE 1. (Continued)

\begin{tabular}{|c|c|c|c|c|c|}
\hline Species & Country & State/Province & $\begin{array}{l}\text { Institution } \\
\text { Storing }\end{array}$ & Voucher Number & $\begin{array}{l}\text { GenBank } \\
\text { Number }\end{array}$ \\
\hline Dasysyrphus venustus & Canada & Ontario & ROME & ROMEnt Spec. No. 57887 & JX828049 \\
\hline Dasysyrphus venustus & South Korea & Kangwon-do & MHPC & JSS 21016 & HQ577444 \\
\hline Dasysyrphus venustus & Canada & Ontario & ROME & ROMEnt Spec. No. 98521 & JX828080 \\
\hline Dasysyrphus venustus & Canada & Ontario & ROME & ROMEnt Spec. No. 98536 & JX828051 \\
\hline Dasysyrphus venustus & United States & Vermont & $\mathrm{CNC}$ & JSS 18338 & GU708485 \\
\hline Dasysyrphus venustus & Canada & Ontario & ROME & ROMEnt Spec. No. 98535 & JX828115 \\
\hline Dasysyrphus venustus & Canada & Ontario & ROME & ROMEnt Spec. No. 98526 & HQ577405 \\
\hline Dasysyrphus venustus & Canada & Ontario & ROME & ROMEnt Spec. No. 98540 & HQ577406 \\
\hline Dasysyrphus venustus & Canada & Ontario & ROME & ROMEnt Spec. No. 98530 & HQ577407 \\
\hline Dasysyrphus venustus & Canada & Manitoba & $\mathrm{CNC}$ & CNCD 9582 & JX827999 \\
\hline Dasysyrphus venustus & Canada & Ontario & $\mathrm{MCZ}$ & JSS 21369 & JX828039 \\
\hline Dasysyrphus venustus & Canada & Ontario & $\mathrm{MCZ}$ & JSS 21371 & JX828027 \\
\hline Dasysyrphus venustus & Canada & Ontario & $\mathrm{MCZ}$ & JSS 21385 & JX827996 \\
\hline Dasysyrphus venustus & Canada & Ontario & $\mathrm{MCZ}$ & JSS 21394 & JX828090 \\
\hline Dasysyrphus venustus & Canada & Ontario & $\mathrm{MCZ}$ & JSS 21397 & JX828020 \\
\hline Dasysyrphus venustus & United States & Alaska & $\mathrm{CNC}$ & CNCD 30902 & HQ577354 \\
\hline Dasysyrphus venustus & United States & West Virginia & CSUC & JSS 20692 & HQ974818 \\
\hline Dasysyrphus venustus & Germany & Niedersachsen & FMNH & JSS 20735 & JN285980 \\
\hline Dasysyrphus venustus & United States & Alaska & $\mathrm{CNC}$ & CNCD 30897 & JX828109 \\
\hline Dasysyrphus venustus & United States & Alaska & $\mathrm{CNC}$ & CNCD 30895 & HQ577350 \\
\hline Dasysyrphus venustus & Canada & Manitoba & $\mathrm{CNC}$ & CNCD9582 & JX828066 \\
\hline Dasysyrphus venustus & United States & Alaska & $\mathrm{CNC}$ & CNCD 30893 & HQ577348 \\
\hline Dasysyrphus venustus & Canada & Ontario & $\mathrm{CNC}$ & CNCD 30890 & HQ577345 \\
\hline Dasysyrphus venustus & Canada & Ontario & ROME & ROMEnt Spec. No. 98534 & JN285979 \\
\hline Dasysyrphus venustus & Canada & Ontario & $\mathrm{CNC}$ & CNCD 30889 & HQ577344 \\
\hline Dasysyrphus venustus & Canada & Ontario & $\mathrm{CNC}$ & CNCD 30888 & HQ577343 \\
\hline Dasysyrphus venustus & South Korea & Kangwon-do & MHPC & JSS 21060 & HQ577449 \\
\hline Dasysyrphus venustus & South Korea & Kangwon-do & MHPC & JSS 21057 & HQ577448 \\
\hline Dasysyrphus venustus & United States & Alaska & $\mathrm{CNC}$ & CNCD 30881 & HQ577339 \\
\hline Dasysyrphus venustus & Canada & Quebec & $\mathrm{CNC}$ & CNCD 68 & JX828001 \\
\hline Dasysyrphus venustus & United States & Virginia & USNM & CNCD 5456 & JX828071 \\
\hline Dasysyrphus venustus & United States & North Carolina & MHPC & JSS 20983 & HQ577437 \\
\hline Dasysyrphus venustus & United States & North Carolina & MHPC & JSS 20985 & JX828036 \\
\hline Dasysyrphus venustus & United States & North Carolina & MHPC & JSS 20987 & JX828056 \\
\hline Dasysyrphus venustus & United States & North Carolina & MHPC & JSS 20988 & JX828075 \\
\hline Dasysyrphus venustus & United States & North Carolina & MHPC & JSS 20982 & JX827997 \\
\hline Dasysyrphus venustus & Canada & Manitoba & $\mathrm{CNC}$ & CNCD 9495 & JX828072 \\
\hline Dasysyrphus venustus & South Korea & Kangwon-do & MHPC & JSS 21050 & HQ577446 \\
\hline Dasysyrphus venustus & Canada & Quebec & $\mathrm{CNC}$ & JSS 20793 & JX828123 \\
\hline Dasysyrphus venustus & United States & North Carolina & CSUC & JSS 20807 & HQ974825 \\
\hline Dasysyrphus venustus & Canada & Quebec & $\mathrm{CNC}$ & CNCD 8658 & HQ577390 \\
\hline
\end{tabular}


TABLE 1. (Continued)

\begin{tabular}{|c|c|c|c|c|c|}
\hline Species & Country & State/Province & $\begin{array}{l}\text { Institution } \\
\text { Storing }\end{array}$ & Voucher Number & $\begin{array}{l}\text { GenBank } \\
\text { Number }\end{array}$ \\
\hline Dasysyrphus venustus & Canada & Quebec & $\mathrm{CNC}$ & CNCD 8656 & HQ577391 \\
\hline Dasysyrphus venustus & Canada & Quebec & $\mathrm{CNC}$ & CNCD 8675 & HQ577392 \\
\hline Dasysyrphus venustus & Canada & Alberta & UASM & JSS 21073 & HQ577452 \\
\hline Dasysyrphus venustus & Canada & Alberta & UASM & JSS 21074 & HQ577453 \\
\hline Dasysyrphus venustus & Canada & Ontario & ROME & ROMEnt Spec. No. 98527 & HQ577394 \\
\hline Dasysyrphus venustus & Canada & Ontario & ROME & ROMEnt Spec. No. 98528 & HQ577395 \\
\hline Dasysyrphus venustus & Canada & Ontario & ROME & ROMEnt Spec. No. 98539 & JX828070 \\
\hline Dasysyrphus venustus & Canada & Ontario & ROME & ROMEnt Spec. No. 98533 & HQ577396 \\
\hline Dasysyrphus venustus & Canada & Ontario & ROME & ROMEnt Spec. No. 98531 & HQ577397 \\
\hline Dasysyrphus venustus & Canada & Ontario & ROME & ROMEnt Spec. No. 98541 & HQ577398 \\
\hline Dasysyrphus venustus & Canada & Ontario & ROME & ROMEnt Spec. No. 98542 & JX828018 \\
\hline Dasysyrphus venustus & Canada & Ontario & ROME & ROMEnt Spec. No. 98524 & HQ577399 \\
\hline Dasysyrphus venustus & Canada & Ontario & ROME & ROMEnt Spec. No. 98522 & HQ577400 \\
\hline Dasysyrphus venustus & Canada & Ontario & ROME & ROMEnt Spec. No. 98523 & HQ577401 \\
\hline Dasysyrphus venustus & Canada & Ontario & ROME & ROMEnt Spec. No. 98525 & HQ577402 \\
\hline Dasysyrphus venustus & Canada & Ontario & ROME & ROMEnt Spec. No. 98532 & HQ577404 \\
\hline Dasysyrphus venustus & Canada & Manitoba & BIOUG & HLC-26539 & GU679670 \\
\hline Dasysyrphus venustus & South Korea & Kangwon-do & MHPC & JSS 21055 & HQ577447 \\
\hline Dasysyrphus venustus & United States & Utah & EMUS & JSS 24642 & JX828009 \\
\hline Dasysyrphus venustus & Canada & Manitoba & $\mathrm{CNC}$ & JSS 24644 & JX828044 \\
\hline Dasysyrphus venustus & Spain & Castilla y Leon & $\mathrm{CNC}$ & JSS 18324 & GU708503 \\
\hline Dasysyrphus venustus & Canada & Ontario & $\mathrm{CNC}$ & CNCD 14567 & JX828005 \\
\hline Dasysyrphus venustus & Canada & Quebec & $\mathrm{CNC}$ & CNCD 14607 & GU708494 \\
\hline Dasysyrphus venustus & Canada & Quebec & $\mathrm{CNC}$ & CNCD 14611 & GU708495 \\
\hline Dasysyrphus venustus & United States & Pennsylvania & USNM & CNCD 5458 & JX828117 \\
\hline Dasysyrphus venustus & Canada & Nova Scotia & $\mathrm{CNC}$ & CNCD 14759 & GU708490 \\
\hline Eupeodes & Serbia & & $\mathrm{CNC}$ & JSS 19735 & HQ974850 \\
\hline Eupeodes lapponicus & Canada & Manitoba & $\mathrm{CNC}$ & CHU05-FLY-091 & JX827998 \\
\hline Eupeodes lapponicus & Canada & Manitoba & $\mathrm{CNC}$ & JSS 18400 & GU708459 \\
\hline Melangyna & South Korea & Kangwon-do & MHPC & JSS 21045 & HQ577445 \\
\hline Melangyna cincta & Germany & & $\mathrm{CNC}$ & CNC DIPTERA 105572 & JX828028 \\
\hline Melangyna guttata & Norway & & $\mathrm{CNC}$ & CNC DIPTERA 105574 & JX828119 \\
\hline Melangyna lasiophthalma & Canada & Ontario & $\mathrm{CNC}$ & JSS 19748 & HQ974845 \\
\hline Melangyna triangulifera & Canada & British Columbia & $\mathrm{CNC}$ & CNC DIPTERA 19312 & JX828086 \\
\hline Scaeva dignota & Serbia & & $\mathrm{CNC}$ & JSS 19737 & HQ974854 \\
\hline Scaeva pyrastri & United States & Colorado & CSUC & JSS 20802 & HQ974821 \\
\hline
\end{tabular}

Specimens submitted to the Barcoding Institute of Ontario were chosen for sampling based on age. Specimens up to 40 years old were originally used; however, many of the older specimens did not yield any DNA. Specimens up to 10 years old were then used with a higher success rate. In all, $~ 60 \%$ of the specimens yielded some sequence data. Sequencing performed by the authors was done to attempt to target sequences from species that were not obtained previously, to gain complete sequences for species where only partial sequences were previously obtained and to gain sequences from newly obtained specimens. Specimens up to 50 years old were used, however younger 
specimens (10 years or younger) typically yielded DNA and specimens older than that were less reliable. In total, COI sequences were obtained for 20 species of Dasysyrphus.

To initially analyze the COI sequence data a neighbour-joining tree was created from 354 sequences (specimens listed in Table 1) using the Barcode of Life Data Systems (Ratnasingham \& Hebert 2007). The neighbour-joining method was used to identify COI sequences that clustered together in the tree. The specimens whose COI sequences made up these clusters were then studied under the microscope to determine if morphological characters existed to separate putative species. Male and female external morphological characters and male genitalic characters were examined. Male genitalia were removed from the specimen, cleared in hot $95 \%$ lactic acid, and mounted in glycerol to be observed. For storage, the genitalia were placed in glycerol in genitalia vials and placed on the original specimen's pin, below the specimen. The molecular data were important in settling the controversy over which characters were variable and which were useful species level synapomorphies. New and often subtle characters were also discovered that may have been lost in the morass of perceived variation during previous work on the genus.

A data matrix consisting of 42 specimens with $658 \mathrm{COI}$ characters each (bases, A, T, C or G) was analyzed more rigorously. Of the 354 total sequences, one sequence that best represented each putative species was chosen; a second sequence was used if a large amount of intraspecific variation appeared on the NJ tree. Thirty-two Dasysyrphus sequences were combined with ten outgroup taxa. Outgroup taxa were chosen from the subfamily Syrphinae. The species Meligramma guttata (Fallén 1817), M. triangulifera (Zetterstedt 1843) and Fagisyrphus cinctus (Fallén 1817) were used because they were found to be sister taxa to Dasysyrphus (Mengual et al. 2008). The remaining seven specimens were chosen due to their hypothesized close relation to Dasysyrphus (Mengual et al. 2008). They are from the genera Scaeva, Eupeodes and Melangyna. A parsimony analysis was conducted using PAUP* 4.0 (Swofford 2003). The outgroup was set to be paraphyletic. A heuristic search was launched, using stepwise addition and 1000 repetitions. Jackknife supports (JKS) were calculated, excluding 36\% of the characters (as recommended by Farris et al. (1996)) and running 100 replicates. Bremer supports (BRS) were generated using TreeRot v3 (Sorenson and Franzosa 2007) and PAUP* 4.0 (Swofford 2003) using a heuristic search.

Bayesian analysis was conducted using MrBayes 3.2.1 (Ronquist et al. 2011), which was submitted remotely to run at the CIPRES Science Gateway V3.1 (Miller et al. 2010). The best-fit model of molecular evolution was determined using MrModeltest v2.3, using the AIC criterion (Nylander 2004). This model was determined to be GTR+I+G. In MrBayes a Markov Chain Monte Carlo (MCMC) method was used. The settings were as follows: two independent runs, with nucmodel $=4 \mathrm{by} 4, \mathrm{~N}_{\mathrm{st}}=6$, rates $=$ invgamma, samplefreq $=1000$, four chains $=$ one cold and three hot. The COI dataset was run for 5 million generations with a burn-in of 1000. A majority-rule consensus tree displaying the posterior probability supports for each node was generated in Mesquite. This was generated using the remaining trees, excluding the burn-in.

Terminology for external morphological characters follows Thompson (1999) and Cumming \& Wood (2009) for the terms not outlined in Thompson's glossary. Terminology for the male genitalia follows Cumming \& Wood (2009). In the species descriptions the majority of the distribution and ecological data were extracted from the CNC specimen database, which contains the label data from all of the specimens loaned to the authors by the institutions listed above. Primary type material is listed before the material examined list and it is indicated in brackets if it was examined. For primary types examined, the label data is listed using " " to indicate each label and / to separate each line of that label. Other information, including sex and deposition is stated here as well. For type material not examined, the information presented was compiled from the literature. The material examined lists present the paratypes examined, followed by all other specimens examined, sorted by country, state/province and latitude. All plant names used in the ecology sections of the species descriptions were verified and updated to current generic and specific concepts through VASCAN (Brouillet et al. 2010) and the USDA PLANTS Database (USDA 2012). For research into the etymology of the scientific names the work by Brown (1956) was used. Etymologies are provided for interest and to add to the knowledge we have regarding Dasysyrphus as none were given in original descriptions. Range maps were created using SimpleMappr (Shorthouse 2010). Images for figures were taken on a Leica DM550B compound microscope (Leica Microsystems Inc., Concord, ON) and a Canon EOS 50D camera equipped with a $100 \mathrm{~mm}$ macro lens (Canon Canada Inc., Mississauga, ON). Genitalia were placed in glycerine gel and wings were placed in water for microscope photography. Leica Applications Suite (Leica Microsystems Inc., Concord, ON) and Zerene Stacker (Zerene Systems LLC, Richland, WA) were used to create the montage images from the microscope and camera respectively. 


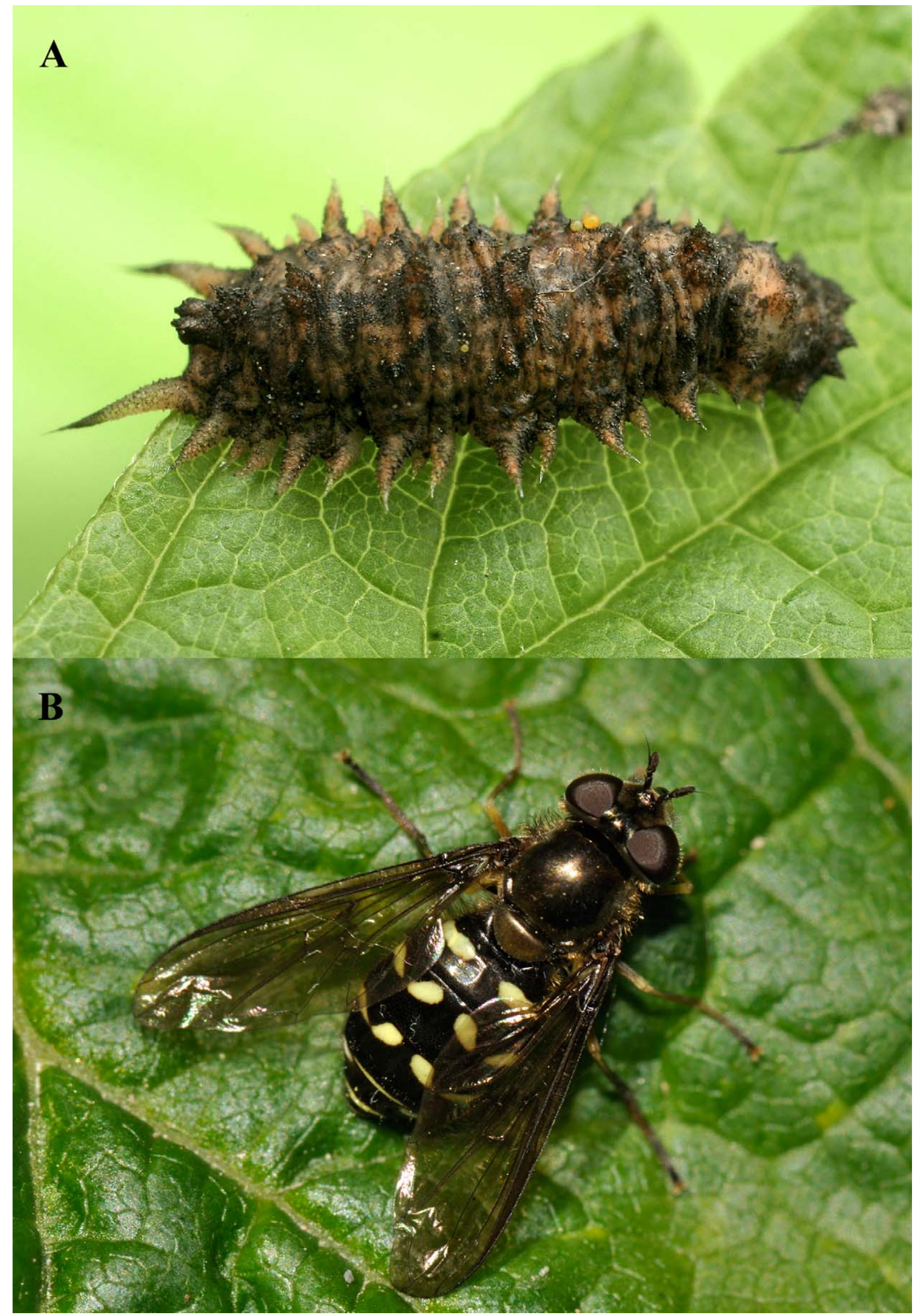

FIGURE 1. A: Dasysyrphus sp. larva (Russia; courtesy of Vladimir Davydov); B: Dasysyrphus intrudens complex adult female (Washington, USA; courtesy of Andrew Young). 
Colour provides important character information in many syrphids and is useful in identifying both genera and species. However, it has been shown that colour in Syrphidae can be temperature dependent. In an experiment by Dusek \& Laska (1974), it was shown that low pupal development temperatures result in darker adults and higher pupal development temperatures result in lighter adults. Preservation techniques and age of the specimen can also affect its colour. Colour characters must therefore be used with caution and one should recognize that there is high probability for variation in these characters within a species. Specimens of Dasysyrphus typically have two colours, yellow and black. In some specimens the yellow has darkened, leaving areas on the specimen looking browner than would be on a live specimen. In other specimens, the black pigment has faded, causing areas to appear lighter, browner than they would on a live specimen. The following key and descriptions use the terms "light" and "dark", as opposed to specifically describing colours seen on specimens. Generally "dark" refers to black and "light" refers to yellow; however, because both colours can look brown and could possibly be described as black or yellow depending on the observer, the authors have chosen to use "light" and "dark" to try to help reduce ambiguity.

\section{Results}

\section{Phylogenetic Analysis}

This is the first quantitative phylogeny, molecular or morphological, proposed for Dasysyrphus. Based on morphology, Dusek \& Laska (1967) assigned subgenera and Vockeroth (1969) placed species into groups. Analysis of the phylogeny based on COI data and a comparison of these results with these previous taxonomic proposals is discussed below.

A semi-strict consensus tree was generated from 26 most parsimonious trees. The semistrict consensus tree resolved one additional node within the intrudens complex compared to the strict consensus tree. The length of the best tree was 505 steps. The Consistency Index (CI) excluding uninformative characters was 0.4141 . The Retention Index (RI) was 0.6826 . For the Jackknife analysis, 143 characters were parsimony-informative. A Jackknife 50\% Majority Rule consensus tree was generated. Jackknife and Bremer support values were mapped onto the semistrict consensus tree (Fig. 2). A majority-rule consensus tree was generated from 8002 trees from the Bayesian analysis (Fig. 3).

Both Bayesian and parsimony analyses support the contention that Dasysyrphus is monophyletic (Figs $2 \& 3$ ). In the Bayesian analysis this is well supported with a Posterior Probability (BPP) of 1.0. Support from the parsimony analysis is weak with Jackknife support (JKS) of 63 and Bremer support (BRS) of 2. The resolved internal nodes of the Dasysyrphus phylogeny are weakly supported. The Bayesian analysis generates a weakly supported polytomy, with few well-supported clades. The semi-strict consensus tree is more resolved, but weakly supported at the deeper nodes.

Dasysyrphus limatus and tricinctus form a well-supported lineage (BPP $=1.0 ; \mathrm{JKS}=100 ; \mathrm{BRS}=12)$ with unique genitalic characters that support the hypothesis (see discussion below). However, placement of this clade is different in both analyses. There is weak support for both its placement as sister to the intrudens complex (Fig. 2) and as sister to all remaining species of Dasysyrphus (Fig. 3). The clade consisting of albostriatus and eggeri is another with high support $(\mathrm{BPP}=1.0 ; \mathrm{JKS}=98 ; \mathrm{BRS}=5$ ). This clade is also supported by unique genitalic synapomorphies (see discussion below). It too is resolved in different positions in both trees. In the Bayesian analysis it is sister to the clade of Dasysyrphus sp. 23 (from South Korea), lenensis, lotus, amalopis, pinastri, occidualis, nigricornis, creper, pacificus, laticaudus and pauxillus (BPP $=0.9955$; Fig. 3 ) and in the parsimony analysis it is weakly supported as sister to all of the other Dasysyrphus (JKS =63; BRS =2; Fig. 2).

The clade of Dasysyrphus sp. 23 (from South Korea), lenensis, lotus, amalopis, pinastri, occidualis, nigricornis, creper, pacificus, laticaudus and pauxillus is well supported in both trees $(\mathrm{BPP}=0.9483 ; \mathrm{JKS}=82$; BRS $=3$ ). Both analyses show similar relationships among species within the clade, with the parsimony analysis being slightly more resolved (Fig. 2).

Dasysyrphus sp. 19 (from Costa Rica) and bilineatus (Matsumura 1917) are poorly supported sister species in the parsimony analysis (Fig. 2) and both are part of the unresolved polytomy backbone of Dasysyrphus in the Bayesian analysis (Fig. 3). 


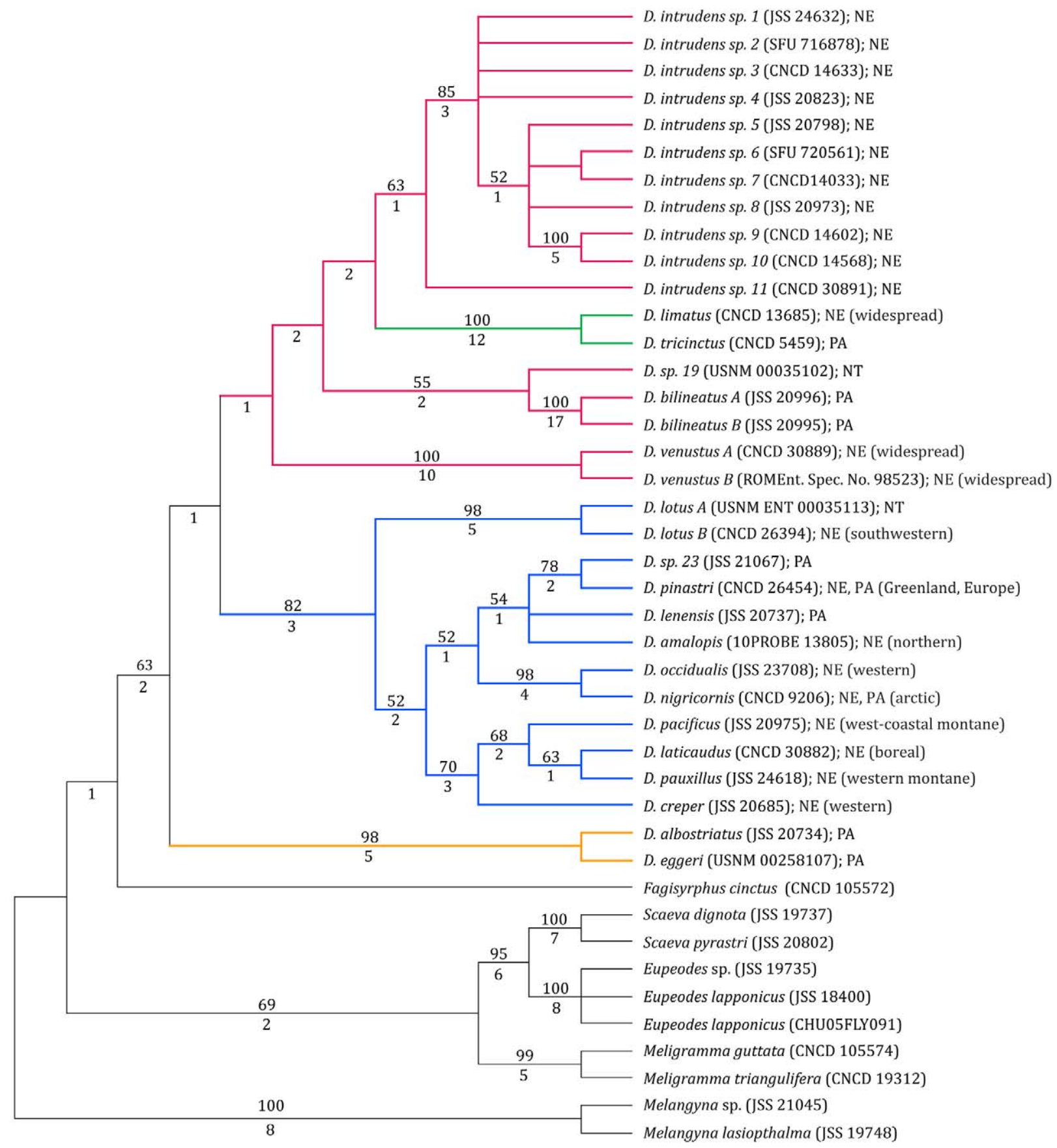

FIGURE 2. Semi-strict consensus tree from 26 most parsimonious trees (Consistency Index (CI) excluding uninformative characters $=0.4141$, Retention Index $(\mathrm{RI})=0.6826$ ); showing Jackknife support values above and Bremer support values below branches. Species groups are highlighted as follows: albostriatus group: orange, pinastri group: blue, tricinctus group: green and venustus group: red (follows updated species groups).

The intrudens species complex is well supported with a $\mathrm{BPP}=1$ in the Bayesian analysis; intrudens sp. 1-10 are strongly supported $(\mathrm{JKS}=85 ; \mathrm{BRS}=3$ ) as a clade with intrudens $s p .11$ weakly supported as sister to this group in the parsimony analysis (Fig. 2). The Bayesian analysis shows strong support for venustus being sister to the intrudens species complex (BPP $=0.9699$; Fig. 3), but venustus is sister to bilineatus $+s p .19+$ the intrudens group in the parsimony analysis (Fig. 2).

In 1967, Dusek \& Laska created subgeneric concepts for Dasysyrphus. They proposed Dasysyrphus s.s. for albostriatus and eggeri, Syrphella Goffe 1944 for tricinctus and Dendrosyrphus Dusek \& Laska 1967 for friuliensis, hilaris, lunulatus (Meigen 1822) and venustus. Vockeroth (1969) treated Syrphella as a synonym of Dasysyrphus for practical reasons (see below). In 1988, Peck treated Dendrosyrphus as a synonym of Dasysyrphus (Peck 1988), without justification. The subgenera proposed by Dusek \& Laska (1967) have been treated as synonyms ever since. 


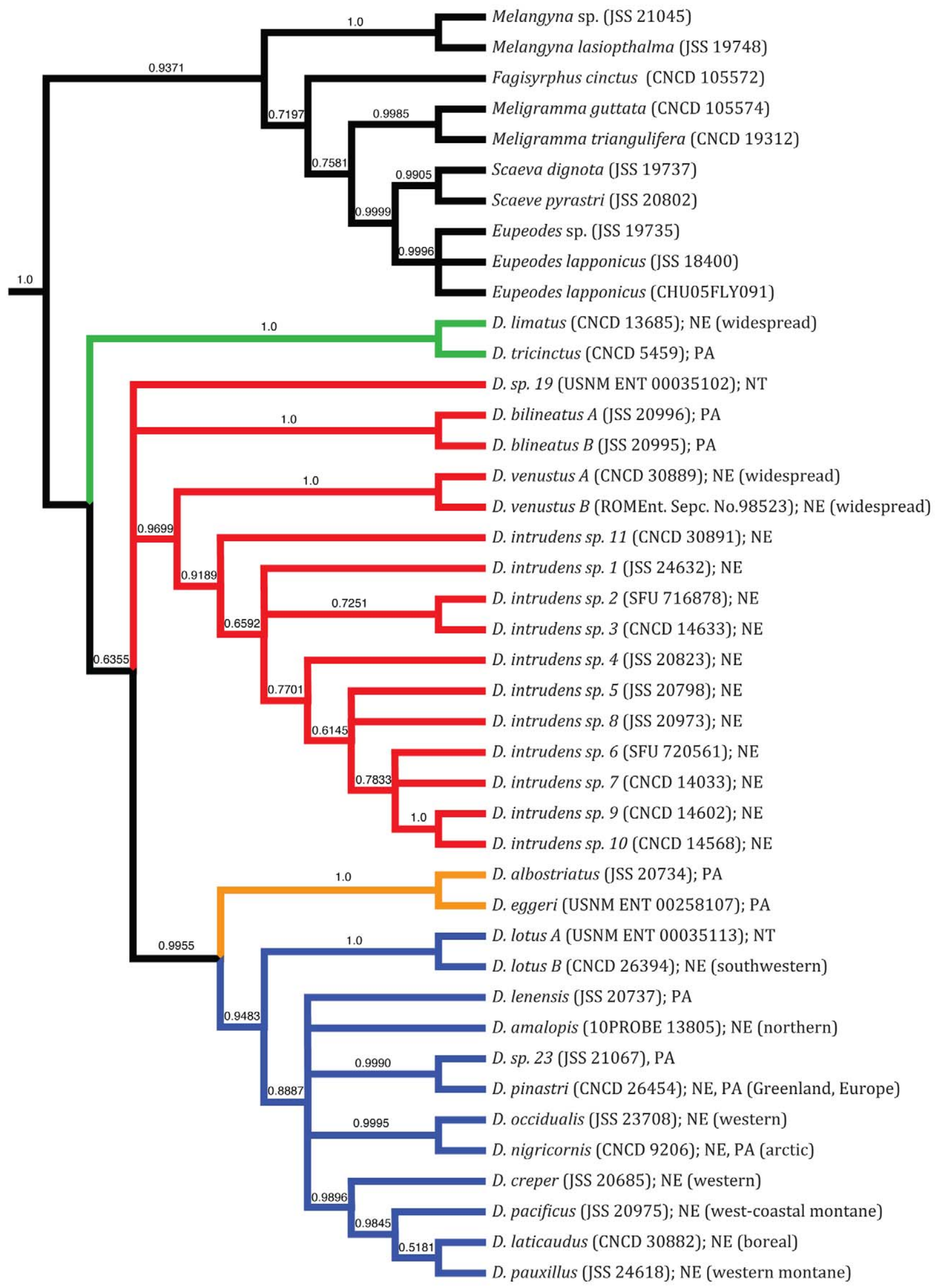

FIGURE 3. Majority rule consensus tree from 8002 trees of Bayesian Markov Chain Monte Carlo analysis. Species groups are highlighted as follows: albostriatus group: orange, pinastri group: blue, tricinctus group: green and venustus group: red (follows updated species groups). 
The other concept put forth to organize the species of Dasysyrphus into taxonomic groupings was proposed by Vockeroth (1969). He suggested using four species groups based on genitalia form, but did not propose subgeneric names because "the absence of definitive external characters makes this course impractical" (Vockeroth 1969). Vockeroth's species groups are: the albostriatus group, including albostriatus and eggeri (Schiner 1861); the lunulatus Meigen 1822 group, including laticaudus, lotus, lunulatus, pacificus, pauxillus and Dasysyrphus sp. (from Brazil); the arcuatus (Fallén 1817) group, including amalopis, arcuatus, bilineatus, hilaris, koningsbergeri (Meijere 1914), osburni, laticaudatus, reflectipennis and Dasysyrphus sp. (from New Guinea); and the tricinctus group, including lotus and tricinctus. Of note: the name arcuatus was suppressed (ICZN 1972) as the name was in a state of confusion and venustus was used instead, as its concept was more stable (Dusek \& Laska 1969). The name lunulatus was in a confused state and had been used for both venustus (of authors) and pinastri (of authors; Vockeroth 1986). Vockeroth (1969) used the name as pinastri; however, its correct usage should be as a synonym of venustus (Vockeroth 1986). The name amalopis was also in a confused state having been used in the sense of amalopis s.s, occidualis sp. nov. (below) and as a species in the intrudens complex in the literature. Vockeroth treats amalopis incorrectly as a member of the intrudens complex. Lastly, lotus is treated twice, in two different species groups, by Vockeroth (1969). Both the Bayesian and Parsimony analyses presented here (Figs 3 \& 2, respectively) suggest that lotus is sister to pinastri and its allies and we believe Vockeroth was correct in placing the latter in his lunulatus group. His placement of lotus in the tricinctus group is odd, as his groupings are based mainly on genitalia and the genitalia of lotus are very different from that of tricinctus. We believe that in his 1969 paper, the name lotus under the tricinctus group is a typographical mistake and that the name limatus was intended. This would make much more sense as the genitalia and external morphological characters as discussed by Vockeroth make sense if looking at limatus, but not lotus.

Based on the phylogeny proposed here, Vockeroth's species groups (with a few nomenclatural updates, as discussed) based on genitalia are congruent with results obtained here. The subgenera proposed by Dusek and Laska are partially congruent; however, another subgenus would need to be erected for the pinastri group to maintain monophyly. We choose to follow Vockeroth and agree that species groups are warranted and are useful in discussing natural groups within Dasysyrphus, but that differences between these groups are not great enough to warrant subgenera within this genus. We support the continued synonymy of subgenera with Dasysyrphus.

Based on evidence from the Bayesian and Parsimony analyses and the material we have seen we propose the following modifications to Vockeroth's species groups:

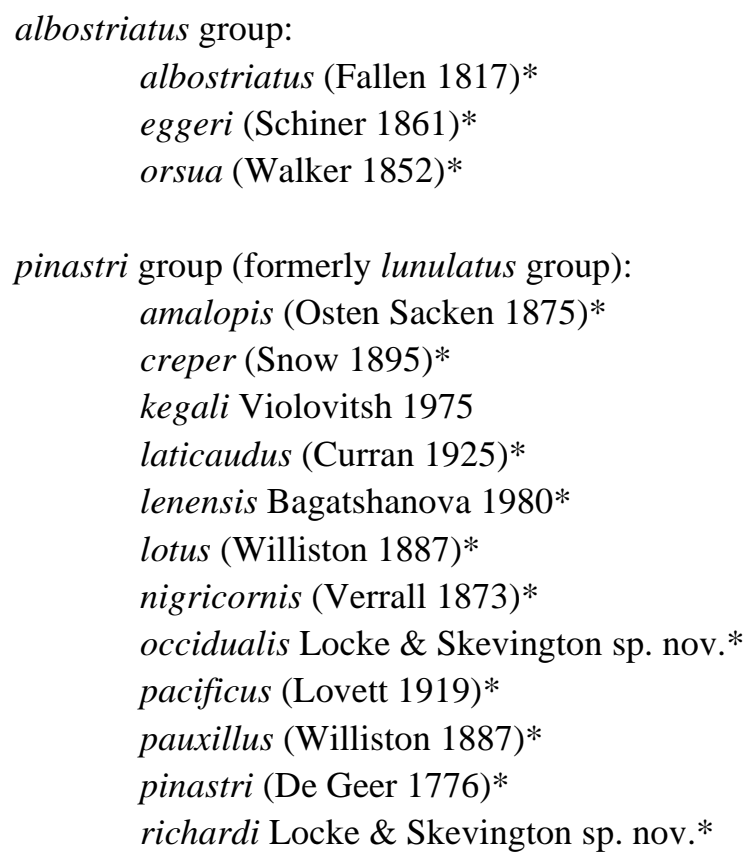

tricinctus group:

limatus (Hine 1922)*

tricinctus (Fallen 1817)* 
venustus group (formerly arcuatus group):

sp. 19 (from Costa Rica)*

bilineatus (Matsumura 1917)*

friuliensis (Goot 1960)*

hilaris (Zetterstedt 1843)*

intrudens species complex (sensu Locke \& Skevington, this paper)*

koningsbergeri (Meijere 1914)

postclaviger (Stys \& Moucha 1962)

venustus (Meigen 1822)*

* - species studied by authors

The concepts proposed by Dusek \& Laska and Vockeroth have highlighted D. tricinctus as a unique species. Genitalia characters given by Vockeroth (1969), mainly the shape and enlargement of the basiphallus and the short distiphallus (Fig. 9D), point to tricinctus and limatus being of close relation, and the parsimony and Bayseian analyses agree (Figs $2 \& 3$ ). Their placement as sister to the intrudens complex (Fig. 2) is not supported by genitalic synapomorphies that characterize the venustus group so their placement as sister to all Dasysyrphus (Fig. 3 ) is preferred.

The albostriatus group is distinctive in both external morphology and genitalia (Vockeroth 1969). The long, slim distiphallus with its apical end tapered (Fig. 19) and the distinct pollinose stripes on the scutum are particularly characteristic of this group. Based on these characters this group was distinguished from other Dasysyrphus by both Dusek \& Laska (1967) and Vockeroth (1969). The COI evidence provided here also supports the concepts promoted by these authors. While their relationship to other Dasysyrphus is not clear from these analyses, there is some morphological evidence to support its placement as sister to the pinastri group (Fig. 3); the shape of the surstyli is similar between these two groups, as they are triangular in lateral view and flattened posteriorly.

The pinastri group (the lunulatus group of Vockeroth (1969)) is well supported by DNA evidence presented here. This group has variations within the shape of its gonostyli, basiphallus and distiphallus, but some similarities in the habitus of these structures reflect the proposed relationship. The gonostyli range from claw- (Fig. 10D) to boot-shaped (Fig. 14D), but the apical ends all taper to a point, and are very dissimilar to the rest of Dasysyrphus. The basiphallus usually has spines (Figs 11D, 8C, 13D, 14D \& 15D) or pile (Fig. 6B) towards the apex, whereas it is smooth in the other Dasysyrphus (Fig. 10D). The basiphallus is faucet-shaped (Figs 6B, 10D, 11D, 8C, 13D, 14D \& 15D) as in other Dasysyrphus, except for the tricinctus group. The pinastri group distiphallus is elongate, sometime bent basally and sometimes with a ventral projection. The apical end is flared out into a horn, both dorsally and ventrally, which is mostly sclerotized but membranous at the apex, usually with setulae dorsally (Figs 6B, 10D, 11D, 8C, 13D, 14D \& 15D). Other Dasysyrphus either have a very shortened distiphallus (the tricinctus group; Fig. 9D), no apical horn (the albostriatus group; Fig. 19) or the horn flares out on the dorsal edge considerably more than the ventral edge and the dorsal side is covered in setae (the venustus group; Figs 7F \& 17D).

The venustus group (arcuatus group of Vockeroth (1969) and Dendrosyrphus of Dusek \& Laska (1967)) is not recovered as monophyletic by either of the analyses presented here; however, they are of close relation in the trees presented. The Bayesian analysis has the majority of the species resolved in a clade, with two species (D. sp. 19 (of Costa Rica) and bilineatus) resolved as a polytomy with the rest of the group (Fig. 3). The parsimony analysis renders this group paraphyletic, with the tricinctus group in the middle (Fig. 2). The species listed in this group have similar genitalic characters. The shape of the gonostyli is similar throughout (Figs 7F \& 17D), although it is similar to that of the tricinctus and albostriatus groups as well. The distiphallus shape is unique to the group, in that it is elongate and flared out into a horn at the apex, but the end is flared more dorsally and the dorsal side is covered in setae (Figs 7F \& 17D). More data are required to test the monophyly of this group. In the meantime it is a convenient grouping to discuss such morphological characters.

While genitalia characters provide considerable insight into the relationships, another species level character should be considered. This is the pattern of the abdominal maculae; more specifically, if those maculae on tergites $3 \& 4$ cross the margin of the abdomen or not. In the tricinctus and venustus groups they cross the margin (Figs 7, 9 
\& 17) and in the albostriatus and pinastri groups they do not (Figs 5, 6, 8, 10-16). The parsimony analysis shows not crossing the margin as the ancestral state, with crossing the margin evolving once (Fig. 2), while the Bayesian analysis shows the opposite (Fig. 3). Either is plausible, although as discussed above, more merit is placed on the Bayesian results. It is hard to imagine why this character is of such significance and is not prone to homoplasy in the group. Both analyses support the high value that has been placed on this character in both past and present efforts to distinguish species or species groups.

This phylogeny supports Vockeroth's zoogeography hypotheses (Vockeroth 1969). There are no clear lineages dividing the Palaearctic and Nearctic, suggesting that there was regular and repeated contact of the fauna in these regions and no clear pattern of radiation in either region. With only a few Neotropical species in existence, it is conceivable that they diversified after arriving from the north once these two regions were connected (Vockeroth 1969). It is difficult to make too many comments on this matter, as this phylogeny is highly biased towards Nearctic taxa. More evidence needs to be gathered to paint a more accurate picture of how all of the species of Dasysyrphus are related and have evolved through time. The addition of more gene regions should add more depth to the analysis, making this a more robust phylogeny and helping to resolve some of the more poorly supported nodes. Based on recent work by Gibson et al. (2010; 2011), we suggest that AATS, parts of CAD and cytochrome $\mathrm{b}$ would be good markers to use in future studies. Fresh material from all known species needs to be collected and preserved in alcohol at -80 degrees to assist in this endeavour.

\section{Species Concepts and Key}

A neighbour-joining tree of $354 \mathrm{COI}$ sequences was produced (Fig. 4). Intraspecific variation and nearest neighbour values were calculated using BOLD Data Systems Nearest Neighbour Summary analysis (Ratnasingham \& Hebert 2007). The results are reported in Table 2.

TABLE 2. Dasysyrphus mean and maximum intraspecific values and nearest neighbour values.

\begin{tabular}{|c|c|c|c|c|c|}
\hline Species & $\begin{array}{l}\text { Number } \\
\text { of } \\
\text { Specimens }\end{array}$ & $\begin{array}{l}\text { Mean } \\
\text { Intraspecific } \\
\text { Variation }(\%)\end{array}$ & $\begin{array}{l}\text { Maximum } \\
\text { Intraspecific } \\
\text { Variation }(\%)\end{array}$ & Nearest Neighbour (NN) & $\begin{array}{l}\text { Distance to } \\
\text { Nearest } \\
\text { Neighbour (\%) }\end{array}$ \\
\hline D. Sp. 19 (from Costa Rica) & 4 & 0.4 & 0.72 & D. intrudens complex & 5.46 \\
\hline D. Sp. 23 (from South Korea) & 1 & N/A & N/A & D. pinastri & 0.16 \\
\hline D. albostriatus & 1 & N/A & N/A & D. eggeri & 2.62 \\
\hline D. amalopis & 11 & 0.14 & 0.5 & D. lenensis & 0.31 \\
\hline D. bilineatus & 4 & 0.46 & 0.93 & D. intrudens complex & 5 \\
\hline D. creper & 22 & 0.31 & 0.87 & D. laticaudus & 1.29 \\
\hline D. eggeri & 1 & N/A & N/A & D. albostriatus & 2.62 \\
\hline D. intrudens complex & 135 & 1.92 & 4.79 & D. amalopis & 3.24 \\
\hline D. laticaudus & 21 & 0.17 & 1.24 & D. pauxillus & 0.46 \\
\hline D. lenensis & 1 & N/A & N/A & D. amalopis & 0.31 \\
\hline D. limatus & 6 & 0.25 & 0.62 & D. tricinctus & 0.46 \\
\hline D. lotus & 3 & 3.09 & 4.30 & D. amalopis & 3.61 \\
\hline D. nigricornis & 7 & 0.31 & 0.94 & D. occidualis & 0 \\
\hline D. occidualis & 12 & 0.11 & 0.32 & D. nigricornis & 0 \\
\hline D. pacificus & 22 & 0.43 & 1.18 & D. laticaudus & 1.4 \\
\hline D. pauxillus & 18 & 0.1 & 0.54 & D. laticaudus & 0.46 \\
\hline D. pinastri & 2 & 0 & 0 & D. Sp. 23 (from South Korea) & 0.16 \\
\hline D. tricinctus & 3 & 0 & 0 & D. limatus & 0.46 \\
\hline D. venustus & 70 & 0.82 & 3.15 & D. intrudens complex & 3.62 \\
\hline
\end{tabular}




\section{FIGURE 4.}

Melangyna cinctalCNCD105572|F|658bp|Germany

Meligramma guttata|CNCD1055741658bplNorway

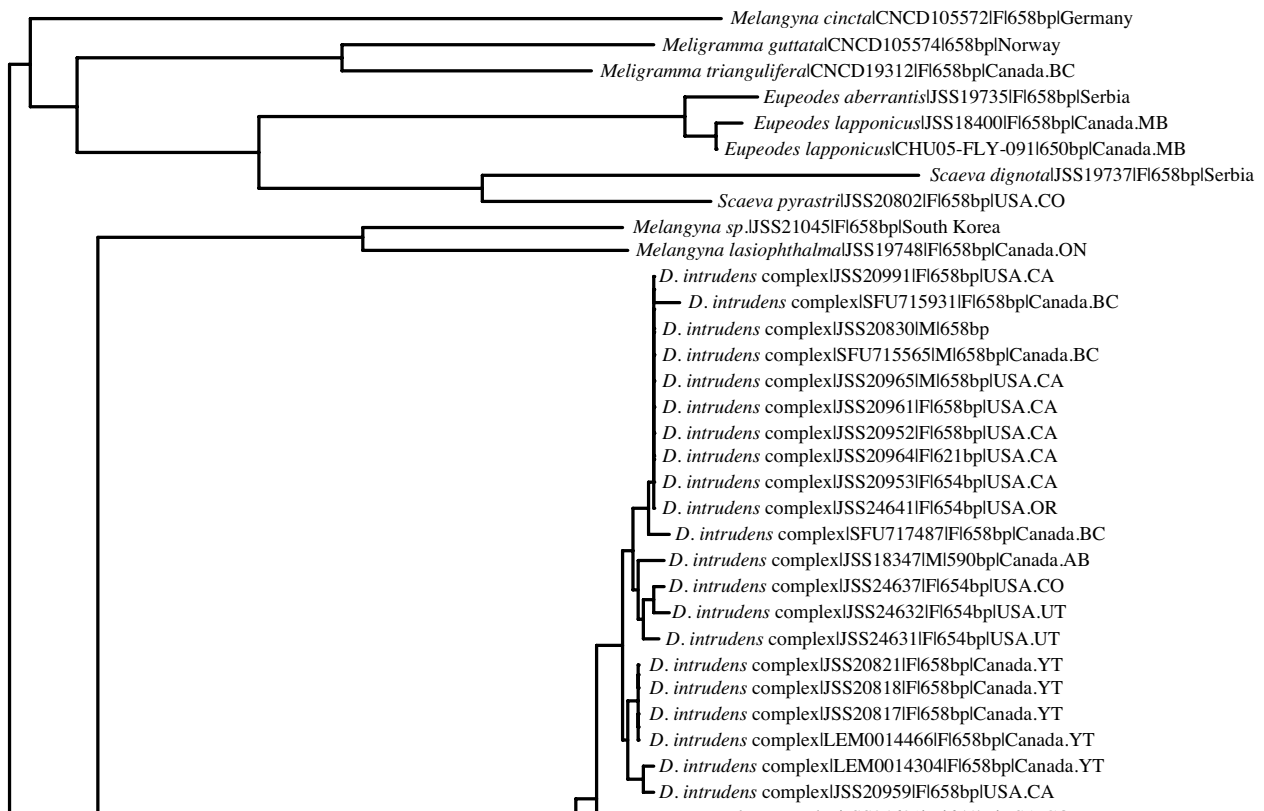

D. intides comlexlJSS20959|F|658bplUSA.CA

D. intrudens complexIROME74269|Fl658bplCanada.ON

D. intrudens complex|CNCD14633|M|658bp|Canada.QC

D. intrudens complexIJSS20792IMI658bplCanada.QC

D. intrudens complex|JSS20794|M|658bp|Canada.QC

D. intrudens complex|CNCD14634|M|589bp|Canada.QC

D intrudens complex|CNCD14772|F|559bplCanada.NS

D. intrudens complexuSS 197381M1658bplCandaC

$D$ intrudens complexIJSS24620|Ml654bplCanada.QC

D. intrudens complexIJSS20744|F|658bplCanada.BC

D. intrudens complex109PROBE-JW01401658bplCanada.MB

D. intrudens complexIJSS19706/FI658bp|USA.CA

D. intrudens complexIJSS20796IMI658bplCanada.QC

D. intrudens complexISFU717335|F|658bplCanada.BC

D. intrudens complexISFU716878|F|658bplCanada.BC

D. intrudens complex|SFU716763|F|658bp|Canada.BC

D intrudens complexIUASM 141937|F|658bp|Canada.BC

D. intrudens complexICNCD30894IMI658bplUSA.AK

D. intrudens complexICNCD30880|F|658bplUSA.AK

$D$. intrudens complex|JSS21072IMI658bp|Canada.AB

D. intrudens complexIJSS237021MI654bplUSA.CO

D. intrudens complexlJSS18330IMI658bplUSA.OR

- D. intrudens complexlJSS24619|M|606pplUSA.UT

$D$. intrudens complexIJSS237041M1654bPIUSA.CO

D. intrudens complexICNCD5441/MI569bplUSA.CO

- D. intrudens complexlJSS20826IMI658bplCanada.BC

D. intrudens complexIJSS20823|M|658bplCanada.BC

D. intrudens complexIJSS207991M|658bplUSA.W

D. intrudens complexIJSS20798|MI654bplUSA.WA

D. intrudens complex|JSS20973|F|658bplUSA.CA

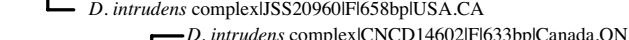

DD. intrudens complexICNCD14602/F1633bplCanada.ON

D. intrudens complexIJSS246341654bplCanada.ON

D. intrudens complexICNCD $30877 \mathrm{M} \mid 658 \mathrm{bplCanada} . \mathrm{QC}$
D.

D. intrudens complexICNCD $308781 \mathrm{M}|658 \mathrm{bp}| \mathrm{Canada}$.QC

D. intrudens complex|CNCD14568|M|658bp|Canada.ON

D. intrudens complexlJSS20800IM|658bp|Canada.QC

$D$ intrudens complex|ROME57891|F|658bplCanada.ON

D. intrudens complexIROME98520151658bplCanda.ON

D. intrudens complexIJSS18343/M|549bplCanada.QC

D. intrudens complexlJSS18343|M|549bplCanada.QC
D. intrudens complexIJSS153311650bplCanada.QC

D. intrudens complexIJSS153311650bp|Canada.QC
D. intrudens complexIJSS17748|M|658bplCanada.QC

D. intrudens complex|SFU717383|M|658bp|Canada.BC

D. intrudens complex|SFU716544|M|658bp|Canada BC

D. intrudens complexISFU715868|F|658bplCanada BC

D. intrudens complex|CNCD14027|M|658bplCanada.YT D. intrudens complexILEM0014302|M|658bp|Canada.YT D. intrudens complexICNCD30892|F|658bp|USA.AK

D. intrudens complex|CNCD14033|M|658bplCanada.YT

D. intrudens complex|CNCD5814|M|602bp|Canada.YT

D. intrudens complexICNCD14034|MI630bp|Canada.YT

D. intrudens complex|CNCD30901|F|658bp|USA.AK

D. intrudens complex|CNCD30900|F|658bplUSA AK

D. intrudens complex|CNCD30879|F|658bplUSA.AK

D. intrudens complexICNCD14035IMI658b

D. inimans complexiCNCD $140351 M 1658$ bplCanada.Y 
FIGURE 4. (Continued)

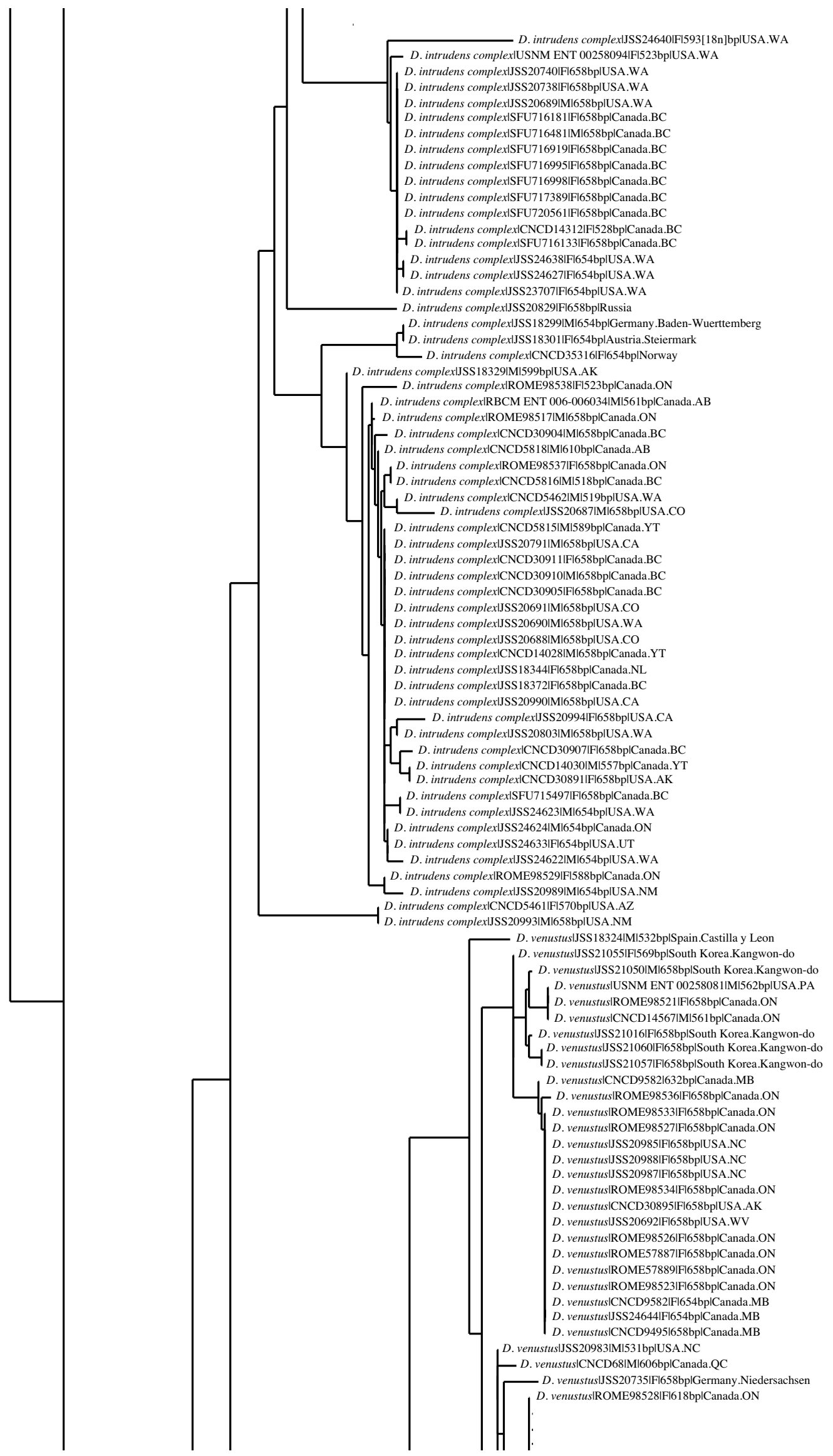

......continued on the next page 
FIGURE 4. (Continued)

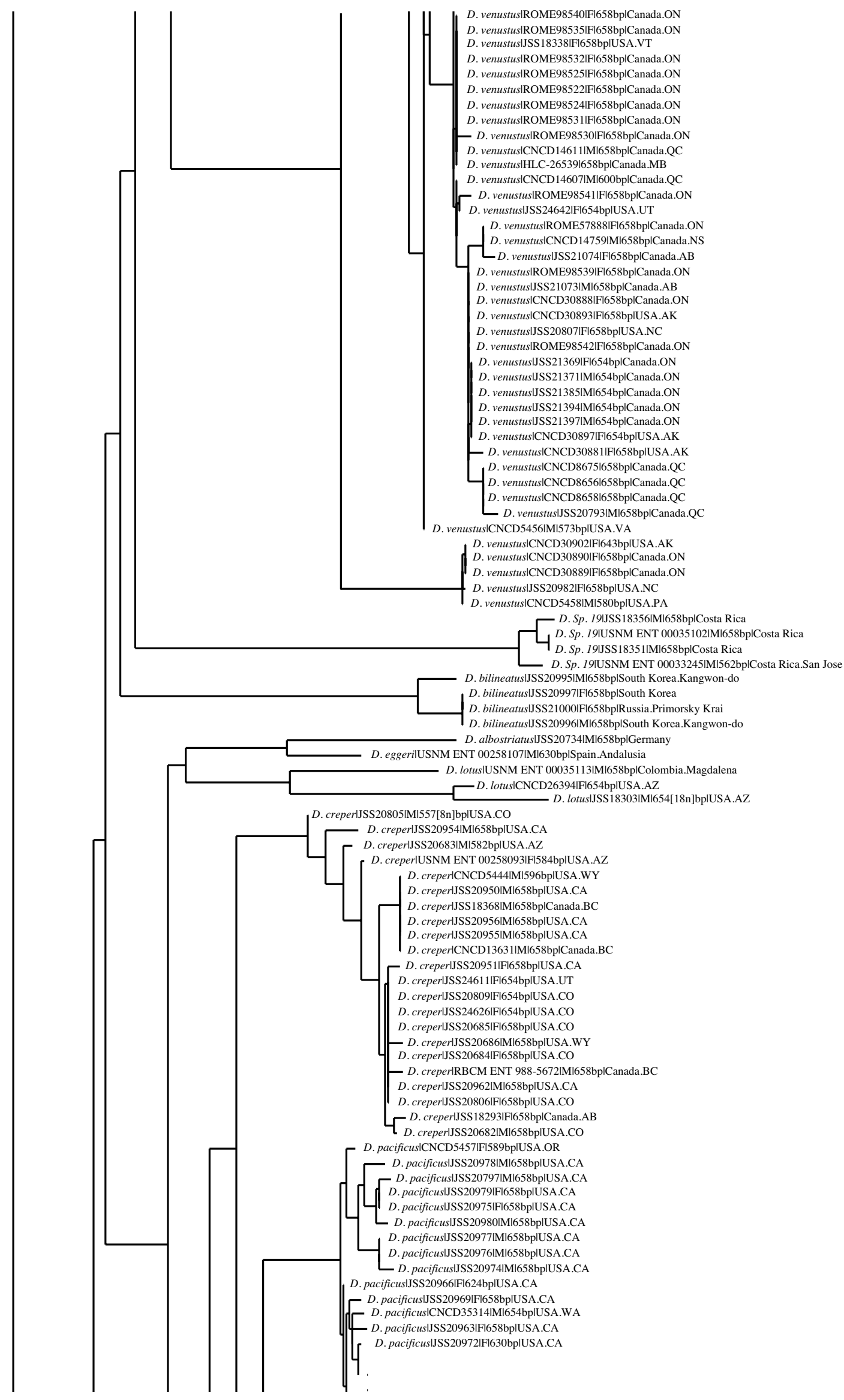


FIGURE 4. (Continued)

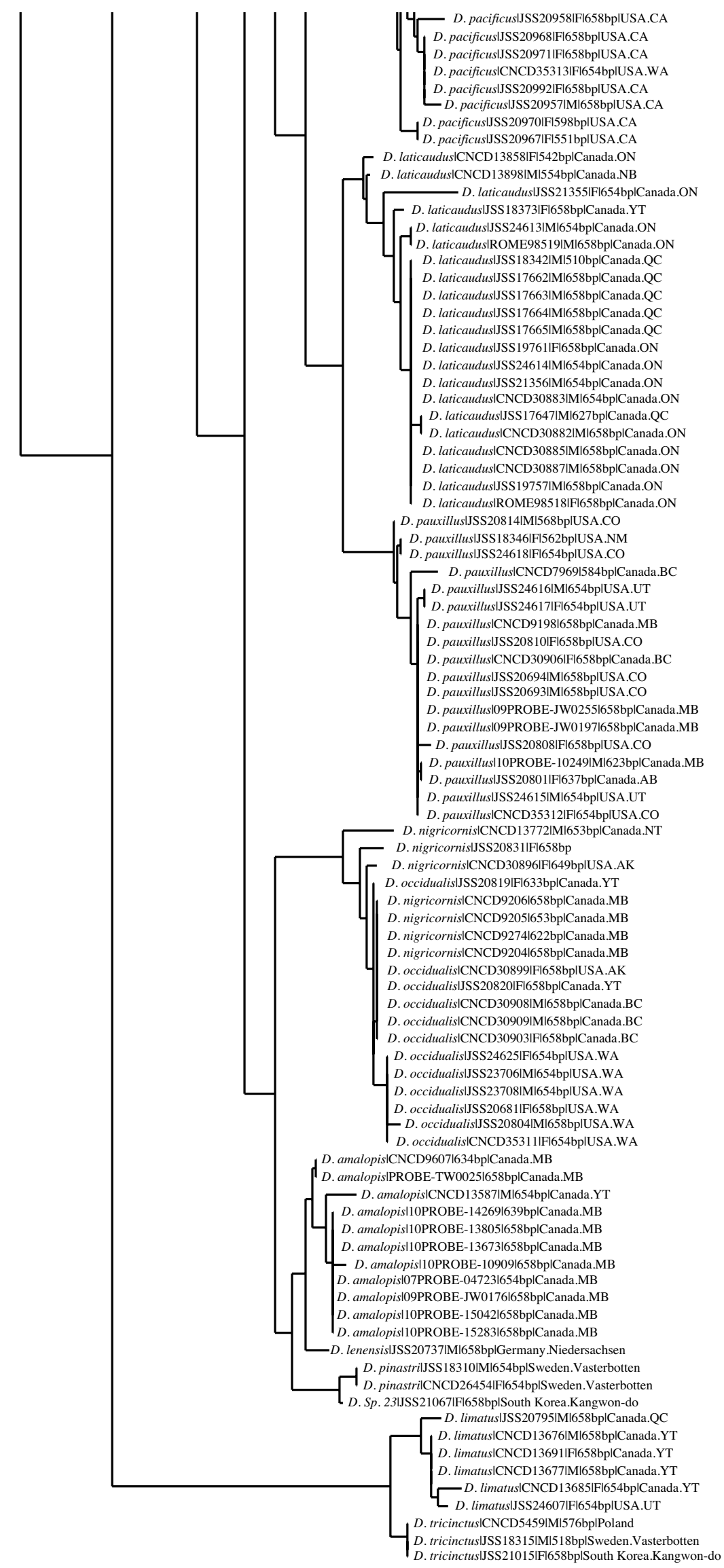

FIGURE 4. Neighbour-joining tree of $354 \mathrm{COI}$ sequences. 


\section{Dasysyrphus Enderlein 1938}

Figures: 1 (field photos), 5-19 (lab photos), 20-22 (range maps)

Synonyms and References:

Conosyrphus Matsumura 1918: 11 (name preoccupied by Conosyrphus Frey 1915). Type species Conosyrphus okunii Matsumura 1918

Dasysyrphus Enderlein 1938: 208. Type species Scaeva albostriata Fallén 1817

Syrphella Goffe 1944: 129. Type species Scaeva tricincta Fallén 1817

Dendrosyrphus Dusek \& Laska 1967: 365. Type species Syrphus lunulatus Meigen 1822

Diagnosis: Eye pilose; metasternum bare; at least at apical $1 / 3$ of wing densely microtrichose; abdomen oval with abdominal margin present, dark with light maculae present on tergites $2,3 \& 4$.

Description:

Body Length: $5.0-11.7 \mathrm{~mm}$; Wing Length: $4.5-11.4 \mathrm{~mm}$

Head: Frons dark with light pollenose fascia (in males it runs along ventral edge of where eyes meet, in females it is variable and can be diagnostic); face light, typically with dark vitta $1 / 4-1 / 2$ the width of the face, reaching antennal socket or not; face with medial tubercle, more prominent in some species than others; gena dark or light; occiput dark, covered in light pollen, pile typically light; eyes covered in dense pile, male holoptic, female dichoptic; scape, pedicel and flagellomere light to dark, arista bare.

Thorax: Scutum dark, usually with shiny or metallic sheen (lighting can enhance sheen); scutellum variable in colour (light to dark); wings densely microtrichose on apical $1 / 3$, location and extent of bare areas on basal $2 / 3$ varies between species; posterior anepisternum, katepisternum, anepimeron, katepimeron with dense pile, usually light, sometimes dark or mixture (colour variable within species); anterior anepisternum, meron, metasternum bare; pterostigma elongate and dark (brown); haltere light, sometimes knob or capitulum darkened; calypter light with long light pile around edge and very short light pile on both dorsal and ventral surfaces; legs cylindrical, femora typically basally dark, apically light, tibiae light, metatibia sometimes with dark band close to apex, tarsi light usually with darker anterior side.

Abdomen: Oval; tergites dark with light maculae, maculae on tergite 2 typically oval, while maculae on tergites $3 \& 4$ are typically longer, arcuate, lunulate, transverse or oblique, sometimes meeting medially, maculae of some species cross abdominal margin (Figs 7, 9 \& 17), in others they do not (Figs 5, 6, 8, 10-16); sternites light with dark maculae or fasciae, sometimes fascia absent on sternite 2; terminalia dark.

Male Genitalia: Hypandrium roughly trapezoid in shape, smooth, without pile; epandrium rounded ventrally with posterior projection (see Figs 6-17 \& 19), smooth, without pile; surstylus more or less triangular in shape in lateral view, flattened posteriorly or anteroposteriorly, long pile on dorsal, laterodorsal and posterodorsal sides, row of spines on posteromedial edge; cercus oval with long pile over entire surface; gonostylus variably shaped; basiphallus variable in shape, but roughly shaped like a faucet, posterodorsal edge bare or covered in pile or spines; distiphallus elongate, basal end flared out into a horn in most species, in D. albostriatus and D. eggeri it tapers to a point (Fig. 19), it is mostly sclerotized but membranous at apex of the horn, with either setae, pile or bare dorsally (Figs 6-17).

Etymology: From the Greek, dasys, meaning thick with hair, hairy, shaggy; and syrphos (masculine), meaning a kind of fly.

Distribution: Throughout Nearctic and Palaearctic (excluding North Africa). Throughout the Neotropical and Oriental regions, however there is low diversity in these regions. Not recorded from the Afrotropical or Australasian regions (Figs 20-22).

\section{Key to Species of Nearctic Dasysyrphus Enderlein 1938}

1. Tergites $3 \& 4$ with maculae that extend over the abdominal margin, usually reaching the edge of the abdomen (cf. Fig. 7D). .

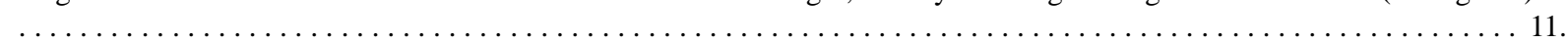

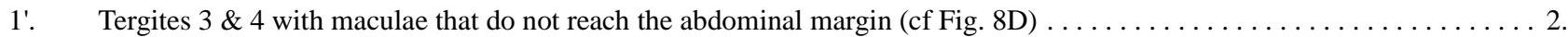

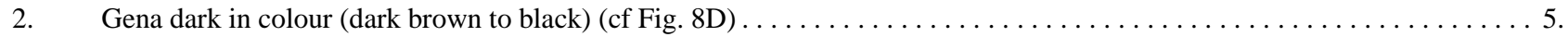

2'. Gena light in colour (yellow to light brown), sometimes with a black vitta between face and gena (cf Fig. 16C) ........ 3.

3. Tergites $3 \& 4$ with maculae arcuate, medial edge flattened, usually broadly contacting the anterior edge of the tergite (Figs 
Western (southern AB \& BC, south to CA \& NM; Fig. 20A); Snow 1895: 234.

3'. Tergites $3 \& 4$ with maculae oblique, more straight, with medial edge rounded and usually meeting medially, sometimes con-

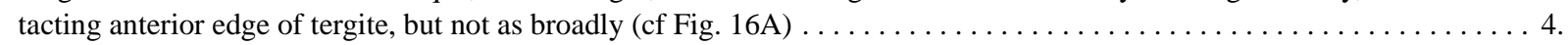

4. Gena separated from face by black vitta; wing cells br and bm almost entirely bare (Figs $16 \mathrm{~A}-\mathrm{C}) \ldots \ldots \ldots \ldots \ldots \ldots$

Southwestern (NM; Fig. 20C); Locke \& Skevington, here described.

4'. Gena and face continuously yellow, not separated by black vitta; wing cells br and bm partly microtrichose (Figs $10 \mathrm{~A}-\mathrm{D})$...

Southwestern (CA \& AZ, south to Mexico; Fig. 21A); Williston 1887: 75.

5. Sternite 2 with dark oval macula (Figs $15 \mathrm{~A}-\mathrm{D}, 18 \mathrm{C}) \ldots \ldots \ldots \ldots \ldots \ldots \ldots \ldots \ldots \ldots \ldots \ldots \ldots \ldots \ldots \ldots \ldots \ldots \ldots \ldots$ pinatri (DeGeer) Greenland (Fig. 21D); De Geer 1776: 113, Pl. 7, Figs 1-7.

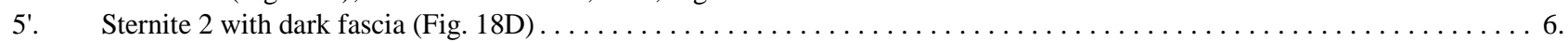

6. Tergites $3 \& 4$ with maculae not greatly constricted, more or less uniform in thickness (cf Fig. 13A) $\ldots \ldots \ldots \ldots \ldots$.

6'. $\quad$ Tergites $3 \& 4$ with maculae greatly constricted medially, sometimes completely divided (Figs 5A, 12A \& B) . . . . . . 7.

7. Male surstylus with a prominent posterolateral edge. Cell br usually with bare areas above base of spurious vein (sometimes very small); tergites $3 \& 4$ with maculae usually divided (Figs 12A-E) ......... occidualis Locke \& Skevington sp. nov. Western (AK, south to CO; Fig. 21B); Locke \& Skevington, here described.

7'. Male surstylus without a prominent posterolateral edge. Cell br densely microtrichose; tergites $3 \& 4$ with maculae either

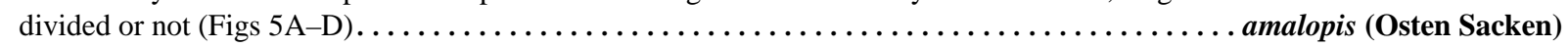
Northern (YK, east to northern NL; NH; Fig. 20A); Osten Sacken 1875: 148.

8. Tergite 2 with anterolateral corner of maculae extending anterolaterally into a point, in females reaching the edge of the abdomen; profemur light, usually entirely so but some dark basally (Figs $8 \mathrm{~A}-\mathrm{E}) \ldots \ldots \ldots \ldots \ldots \ldots$ laticaudus (Curran) Eastern and boreal (AK, east to NL, south to NH, Fig. 20C); Curran 1925: 175, Pl. XI, Fig. 151.

8'. Tergite 2 with anterolateral corner of maculae not extending anterolaterally into a point, lateral edges of maculae usually rounded (cf Fig. 13B); profemur dark basally, light apically to entirely dark (cf Fig. 14B) . . . . . . . . . . . . . .

9. Size 5.5-7.7 mm, dark flies; profemur $1 / 2$-entirely dark; pubescent band on female frons complete but sometimes not well defined; males with tergite 2 maculae typically reduced and positioned toward the lateral edge; tergites $3 \& 4$ uniform in width and slightly constricted medially; gonostylus boot-shaped with projection on posterodorsal surface that projects posterodor-

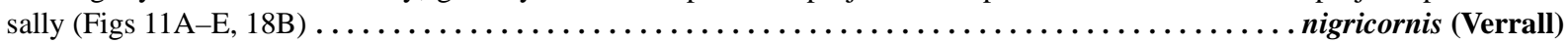
Northern (AK, east to northern NL; Greenland; Fig. 21A); Verrall 1873: 251.

9'. Combination of characters not as above. Size 5.0-9.7 mm, profemur never entirely dark (1/3-2/3 dark basially); pubescent band on female frons interrupted; males with tergite 2 maculae large $(1 / 3-1 / 2$ width of tergite); tergites $3 \& 4$ uniform in width and slightly constricted medially; gonostylus boot-shaped with projection on posterodorsal surface that projects more dorsally (Fig.

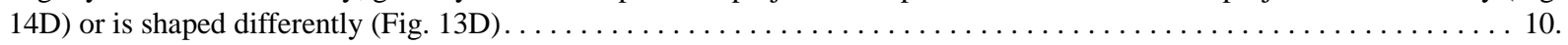

10. Male gonostylus with narrow, wavy projection on posterodorsal surface. Wing typically largely bare basally, with cells br and

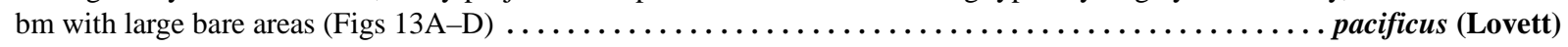
Western, (southern BC, south to CA; Sierra Nevada, Cascades and Costal Mountain Ranges; Fig. 21C); Lovett (in Cole \& Lovett) 1919: 245.

10'. Male gonostylus with projection on posterodorsal surface straight; wing typically densely microtrichose, sometimes with bare

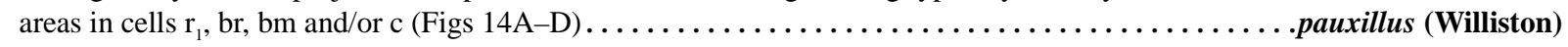
Western (AK, south to NM; Rocky Mountain Range; Fig. 21D); Williston 1887: 74.

11. Tergite 2 with maculae very small, $<1 / 4$ width of tergite; tergites $3 \& 4$ with maculae transverse, usually narrow, with slight swelling on medial edge and narrowing towards margin (Figs 9A-D) $\ldots \ldots \ldots \ldots \ldots \ldots \ldots \ldots \ldots$ limatus (Hine) Widespread (AK, east to NS, south to CO and MA; Fig. 20D); Hine 1922: 146.

11'. Tergite 2 with maculae large, $>1 / 3$ width of tergite; tergites $3 \& 4$ with maculae distinctly arcuate, lunulate or oblique, with at least slight swelling on medial edge, sometimes constricted medially (Figs 7A, C, E \& 17A) . . . . . . . . . . . .

12. Tergites $3 \& 4$ with maculae distinctly arcuate or lunulate, with anterior edge forming a distinct $\mathrm{U}$ or $\mathrm{V}$ shape, maculae are distinctly constricted, sometimes dividing in half with a large swelling on the medial edge (Figs 7A-F). ...

Widespread (AK, east to NL, south to CA, NM and TN; Fig. 20B); Osten Sacken 1877: 326.

12'. Tergites $3 \& 4$ with maculae are more oblique, no distinctive constriction in the centre, never divided and not greatly swollen

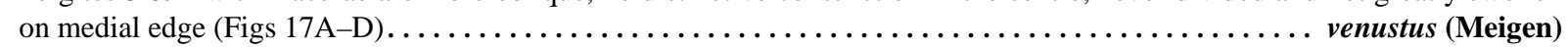
Widespread (AK, east to NS, south to NM \& NC; Fig. 22); Meigen 1822: 299.

\section{Taxonomy}

\section{Dasysyrphus amalopis (Osten Sacken)}

Figures: 5A-D, 20A

Synonyms and References: 
Syrphus amalopis Osten Sacken 1875: 148 (original description)

Curran 1925: 179 (discussion, amalopis s.l.)

Metasyrphus amalopis (Osten Sacken):

Fluke 1933: 110 (in part; key, redescription and transfer to Metasyrphus)

Dasysyrphus amalopis (Osten Sacken):

Stone et al. 1965 (in part): 563 (catalogue and transfer to Dasysyrphus)

Vockeroth 1986: 202 (lectotype designation and discussion)

Vockeroth 1992: 63 (in part; redescription)

Diagnosis: Abdominal maculae do not meet abdominal margin; maculae on tergites $3 \& 4$ are constricted medially and usually not divided (Figs 5A \& B). Wing cells are densely microtrichose (Fig. 5D). Surstylus without a prominent posterolateral edge (Fig. 5C). Similar to D. occidualis, but D. occidualis has maculae on tergites $3 \& 4$ either divided or undivided (Figs 12A \& B), cell br usually with a small bare area above base of spurious vein and a prominent posterolateral edge on the surstylus (Fig. 12D).

Redescription:

Body Length: 7.8-10mm; Wing Length: 7.7-8.7mm

Head: Frons dark with light pollenose fascia (in males it runs along ventral edge of where eyes meet, in females it is continuous, $1 / 4-1 / 2$ the length between the antennae and ocelli) and dark pile; face light with dark vitta $1 / 4-1 / 3$ the width of the face sometimes reaching antennal socket, face with dark pile; gena dark with pile light to dark; occiput dark, covered in light pollen, pile light; scape, pedicel and flagellomere dark.

Thorax: Scutum dark, may appear shiny or metallic, pile varying from all dark to mixed to all light, more light anteriorly and posteriorly; scutellum light (dark yellow) to dark with darker lateral edges, light pile along anterior edge and dark pile elsewhere; wing completely densely microtrichose (Fig. 5D); haltere light; femora $2 / 3-3 / 4$ dark basially, $1 / 4-1 / 3$ light apically, tibiae dark with very basal end light, tarsii dark.

Abdomen: Maculae on tergite 2 large and oval, usually with slight narrowing medially, $1 / 3-<1 / 2$ the width of tergite 2 , maculae on tergites $3 \& 4$ are oblique, constricted medially and usually not divided, posterior edge of maculae straight, maculae do not reach abdominal margin (Fig. 5B); sternite 2 light with a dark triangular macula, usually not connecting with the lateral edges of the sternite, sternites $3 \& 4$ are light with dark fasciae.

Male Genitalia: Surstylus more or less triangular in shape in lateral view, flattened posteriorly, long pile on dorsal, laterodorsal and posterodorsal sides, row of spines on posteromedial edge; cercus oval with long pile over entire surface; gonostylus claw-shaped, pile on dorsal surface; basiphallus elongate, basally bent at about a 90 degree angle towards the anterodorsum, apical end curved ventrally with a widened apex and is partly membranous dorsally, with spines on posterodorsal side, apex; distiphallus elongate, apical end flared out into horn, which is mostly sclerotized but membranous at apex with minute setulae dorsally, basally bent towards dorsum and slightly enlarged ventrally at bend (Fig. 5C).

Intraspecific variation: From the specimens we have had the chance to observe the maculae on tergites $3 \& 4$ are usually not divided (Fig. 5A). Sometimes only the maculae on tergite 3 are divided and sometimes they are divided on both tergites $3 \& 4$. The lectotype male has entire maculae, whereas the paralectotype female has divided maculae.

Etymology: From the Greek, amalos meaning soft, tender, weak and -opis, meaning having the appearance of, like.

Distribution: Northern Canada (MB, NL, QC, YK) and Northeastern USA (NH) (Fig. 20A)

Ecology: Collected from June-July at elevations from sea level-1006m.

Discussion: In addition to the two specimens selected as lectotype and paralectotype by Vockeroth (1986), Osten Sacken (1875) discussed a third specimen and included it in his description of the species. This third specimen has abdominal maculae that cross the abdominal margin. This third specimen is not a specimen of $D$. amalopis but a specimen of the $D$. intrudens complex, and has caused much confusion over the name D. amalopis. Vockeroth (1986) pointed out that Fluke (1933) discussed many specimens of D. amalopis with maculae reaching the margin. Vockeroth stated that he believed those specimens belonged to his concept of D. venustus. We argue that specimens described as $D$. amalopis that have maculae that cross the abdominal margin belong to the $D$. intrudens complex. Fluke (1933) does have D. amalopis key out in two places in his key. The D. amalopis keyed out in couplet 54 pertains to D. amalopis s.s. and D. occidualis, while the D. amalopis keyed out in couplet 56 pertains to the $D$. intrudens complex. 


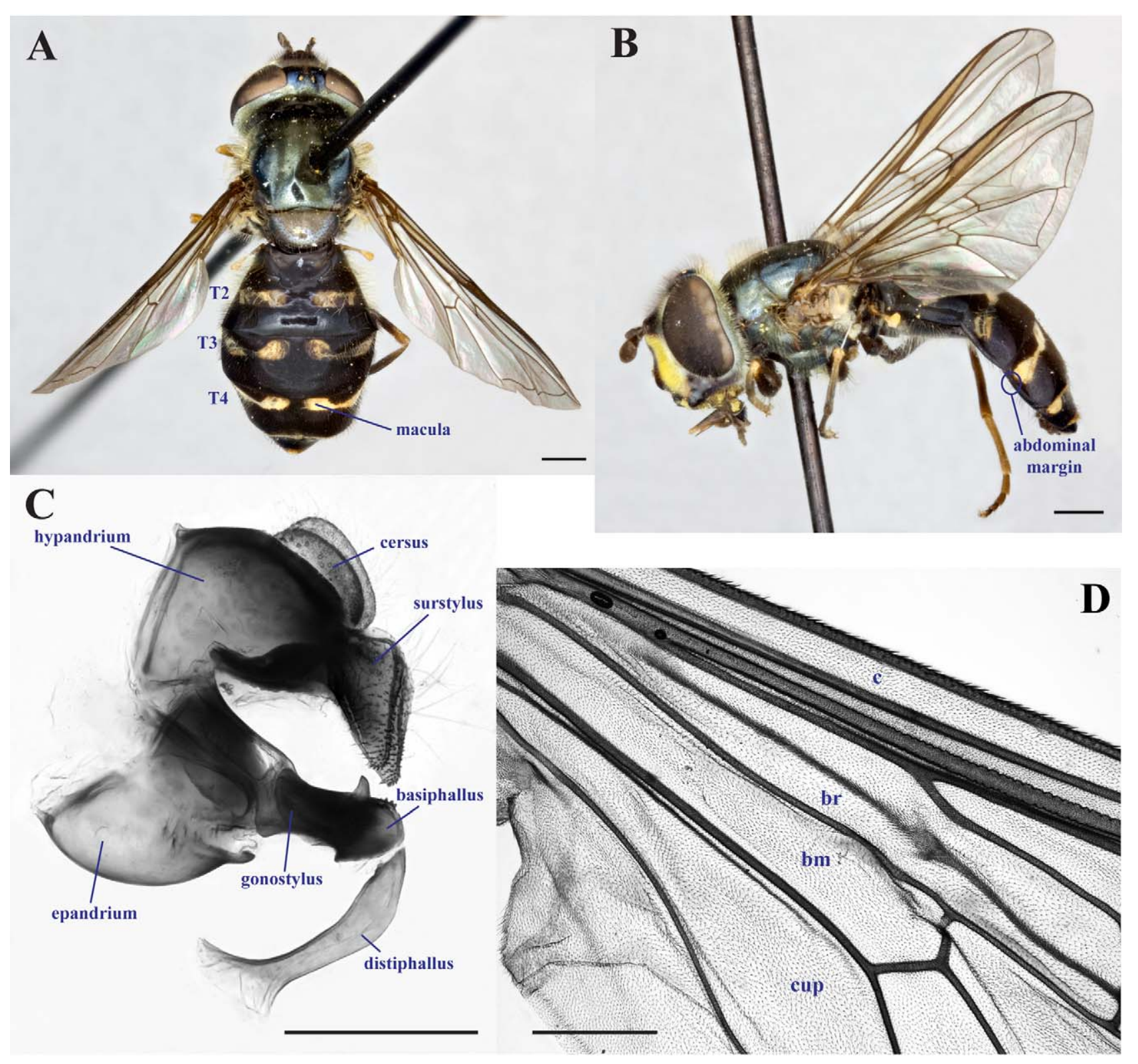

FIGURE 5. Dasysyrphus amalopis: A: female (CNCD 13616) dorsal habitus, T = tergite; B: female (CNCD 13616) lateral habitus; C: lateral view of male (CNCD 9607) genitalia; D: wing base (CNCD 13587). Dorsal and lateral habitus scale bar = $1 \mathrm{~mm}$, genitalia and wing scale bar $=500 \mu \mathrm{m}$.

The lectotype and paralectotype are the only known specimens of this species from eastern North America south of northern Quebec and Labrador. Our new species, Dasysyrphus occidualis, has been confused with $D$. amalopis. However, the COI sequences and male genitalia characters provide evidence for these being two distinct species with an identical habitus. Dasysyrphus amalopis ranges from southern Yukon to northern Labrador (Fig. 20A), while D. occidualis ranges from Alaska, south to Colorado (Fig. 21B). Specimens referred to as D. amalopis from western Canada or the US are most likely that of D. occidualis and in the overlap zone in southern Yukon male genitalia and/or COI sequences should be used to confidently identify specimens. Despite the long standing use of the name D. amalopis, the similar new species, D. occidualis, has been much more frequently collected.

It is not known why no other specimens are known from as far south as the lectotype and paralectotype. They were both collected in the White Mountains, in New Hampshire. The date of their collection is unknown, however their description by Osten Sacken was published in 1875, so they would have been collected previous to that. It is possible that they are rare and have thus not been collected again or that their habitat or climatic conditions have changed resulting in their extirpation. More collecting should be done in the Appalachians at high elevation to see if this species still exists that far south. 
Type Material: "White Mts./ Austin”, "Osten/ Sacken/ Coll.", red label "Type/ 4092”, "Syrphus/ amalopis/ Type Species O.S.", yellow label "LECTOTYPE/ Syrphus/ amalopsis O.S./ Desig. Thompson 1971", "Jan.-July 2003/ MCZ Image/ Database", J. Skevington/ Specimen \#/ 23785", O', deposited in the Museum of Comparative Zoology, Harvard University (MCZ). Missing head. (examined)

Material Examined:

Paralectotype: United States of America: New Hampshire: Gorham, [44.387788, -71.17313], 9 , JSS 23786 (MCZ). Other Material Examined: Canada: Manitoba: Churchill Region: Weir, [58.4026, -94.129], ${ }^{\lambda}$, 25.vii.2007, + , 07PROBE 4723, L.E. Roscoe (CNC); Burn site North of Twin lakes, [58.61861111, -93.82888889], 5.vii.2007, Ô, CNCD 9607, J. Skevington (CNC); Twin Lakes, [58.63, -93.819], 14m, 19.vii.2009, ๆ, 09PROBE 176, (CNC), 26.vi.2010-2.vii.2010, ô, 10PROBE 13673, 5.vii.2010-9.vii.2010, + , 10PROBE 13805, J. Wang (USNM); Goose Creek, [58.649, -94.193W], 19.vii.2009,, , 09PROBE 25, A. Thielman (CNC); Farnworth Lake (Landing L), [58.7045, -94.0525], 14m, 14.vii.2010, क, 10PROBE 14269, 14.vii.2010-19.vii.2010, ô, 10PROBE 15042, 28.vi.2010, ô, 10PROBE 10909, 28.vi.2010-6.vii.2010, +, 10PROBE 15283, J. Wang (CNC). Newfoundland and Labrador: Nain, Anatalak Bay, [56.5429, -61.689989], 16.vii.1928, Ô, JSS 19248, A.C. Weed (FMNH ). Quebec: Indian House Lake, [56.328482, -64.720845], 19.vii.1954; + CNCD 13616, 25.vii.1954, ㅇ, CNCD 13618,W.R. Richards (CNC); 22.vii.1954, ㅇ, CNCD 13617, R. Coyles (CNC). Yukon Territory: La Force Lake, [62.683333, -132.333333], 1006m, 26.vi.1960, §, CNCD 13587, J.E.H. Martin (CNC).

\section{Dasysyrphus creper (Snow)}

Figures: 6A-D, 20A

Synonyms and References:

? Syrphus lotus Williston 1887: 75 var. (short description of a variety of lotus)

Syrphus pauxillus Snow 1892: 37 (nec. Williston; short description)

Syrphus creper Snow 1895: 234 (original description)

Syrphus lotus Curran 1925: 92 Pl. VI Fig. 51 (nec. Williston; redescription)

Syrphus lotus var. creper Curran 1925: 180 (discussion)

Metasyrphus creper (Snow):

Fluke 1933: 107 (key, redescription and transfer to Metasyrphus)

Dasysyrphus creper (Snow):

Stone et al. 1965: 563 (catalogue and transfer to Dasysyrphus)

Vockeroth 1986: 202 (lectotype designation)

Vockeroth 1992: 65 (key and redescription)

Diagnosis: Abdominal maculae do not meet abdominal margin; maculae on tergites $3 \& 4$ arcuate with medial edge flattened and usually broadly contacting anterior edge; markings unlike any other species (Figs 6A \& C).

Redescription:

Body Length: 6.7-10.5mm; Wing Length: 6.3-9.2mm

Head: Frons dark with light pollenose fascia (in male it runs along ventral edge of where eyes meet, in females it is $1 / 2$ the length between the antennae and ocelli) and dark pile; face light with dark vitta $1 / 4-1 / 3$ the width of the face, usually not reaching antennal socket, face with light pile, dark pile lateral to the eye; gena light (Fig. 6C) with light pile and usually some dark pile below eye; occiput dark, covered in light pollen, pile light; scape and pedicel light to dark, flagellomere dark.

Thorax: Scutum dark, may appear shiny or metallic, pile light; scutellum light to dark with darker lateral edges, light pile along anterior edge and dark pile elsewhere; wing cells br and bm entirely bare, cell $\mathrm{c}$ bare from base to $3 / 4, \mathrm{r}_{1}$ bare at base and cup bare at base and along vein CuP (Fig. 6D); haltere light; pro- and mesofemora $1 / 3-1 / 2$ dark basially, $1 / 2-^{2 / 3}$ light apically, metafemur $2 / 3-3 / 4$ dark basially, 1/4-1/3 light apically, tibiae light, metatibia with dark band $1 / 4$ of the way from the apex, tarsii light, sometime dark anteriorly.

Abdomen: Maculae on tergite 2 large and oval, maculae on tergites $3 \& 4$ are arcuate, with medial edge widened, flattened and usually broadly contacting the anterior edge of tergite, sometimes meeting medially, maculae do not reach abdominal margin (Figs 6A \& C); sternites light with dark fasciae.

Male Genitalia: Surstylus more or less triangular in shape in lateral view, flattened posteriorly, long pile on dorsal, laterodorsal and posterodorsal sides, row of spines on posteromedial edge; cercus oval with long pile over 
entire surface; gonostylus boot-shaped with projection on posterodorsal surface that projects dorsally, pile on dorsal surface; basiphallus elongate, basally bent at 90 degree angle towards dorsum, apical end curved ventrally and is partly membranous with pile on dorsal side; distiphallus elongate, apical end flared out into horn, which is mostly sclerotized but membranous at apex with minute setulae dorsally, basally bent towards dorsum and slightly enlarged at bend (Fig. 6B).
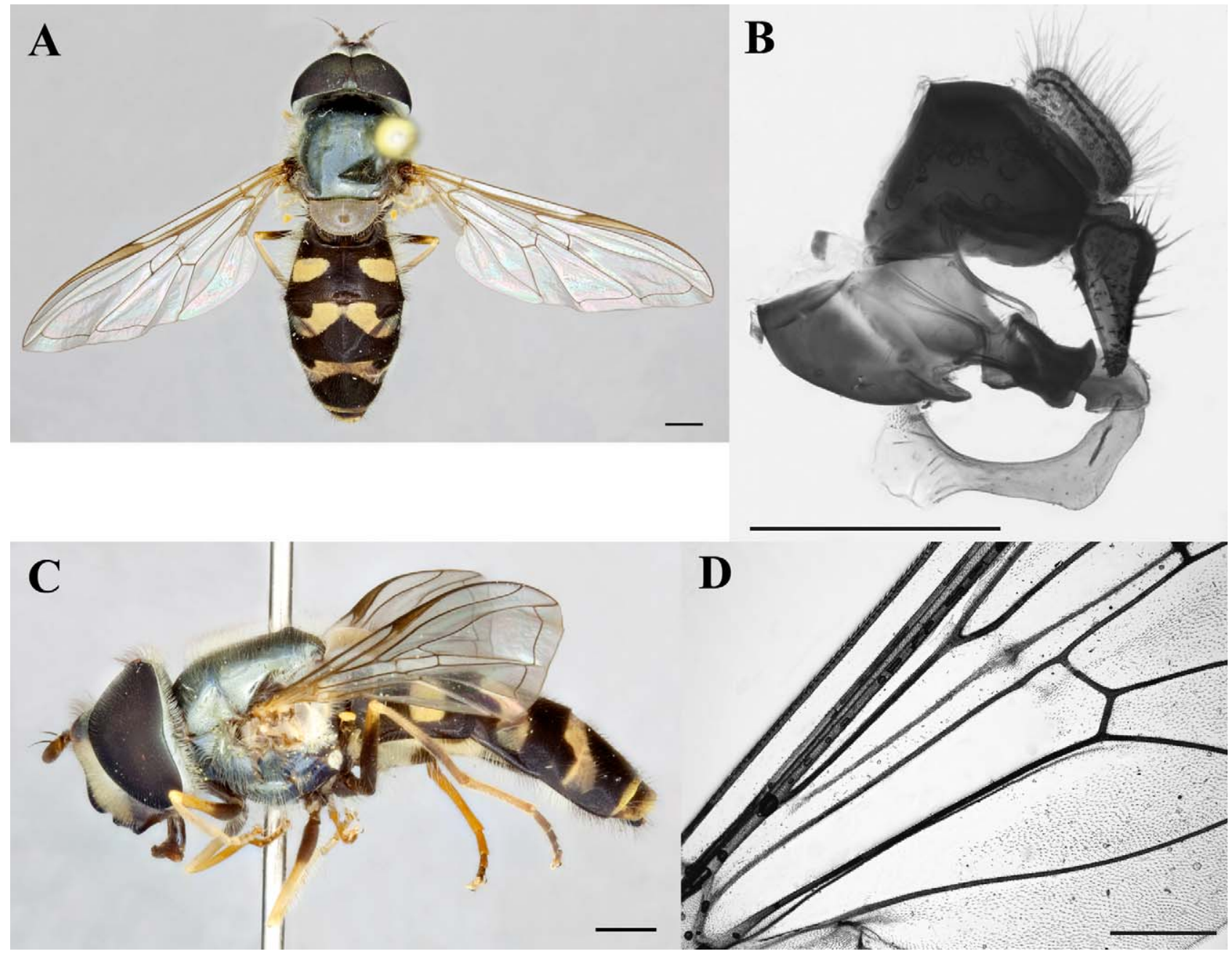

FIGURE 6. Dasysyrphus creper: A: male (CNCD 26355) dorsal habitus; B: lateral view of male (JSS 20682) genitalia; C: male (CNCD 26355) lateral habitus, genitalia removed; D: wing base (CNCD 26363). Dorsal and lateral habitus scale bar = $1 \mathrm{~mm}$, genitalia and wing scale bar $=500 \mu \mathrm{m}$.

Intraspecific variation: Scutellum colour varies from light to dark; maculae on tergites $3 \& 4$ sometimes meet medially and sometimes are separated, medial edge usually broadly contacts anterior edge of tergite but if not then it comes close to anterior edge and edge of maculae are rounded; dark fasciae on sternites vary in width.

Etymology: The word creper is Latin, meaning dark or obscure.

Distribution: Southwestern Canada (AB, BC) and western USA (AZ, CA, CO, ID, MT, NM, OR, SD, UT, WA, WY). (Fig. 20A)

Ecology: Collected on ponderosa pine (Pinus ponderosa Douglas ex Lawson \& C. Lawson, Pinaceae), sierra willow (Salix orestera C.K. Schneid., Salicaceae), willow (Salix Linnaeus, Salicaceae), chokecherry (Prunus virginiana, Rosaceae), Ross' avens (Geum rossii (R. Brown) Seringe, Rosaceae), avens (Geum Linnaeus, Rosaceae), tall ragwort (Senecio serra Hooker, Asteraceae), threenerve goldenrod (Solidago velutina DC., Asteraceae), rabbitbush (Chrysothamnus Nuttall, Asteraceae). Habitats listed on labels include "along timberline", "creek margin" and "on tundra". The specimen collected on the "tundra" was collected in Colorado at 3505m, so this is in reference to an alpine tundra habitat. Collected April to October, although much more frequently collected in July and August. Collected from elevations of $305 \mathrm{~m}-3688 \mathrm{~m}$, although most frequently collected from elevations above $2000 \mathrm{~m}$. 
Discussion: Presumably Williston (1887) was referring to a specimen of $D$. creper when he described the female from New Mexico as a second specimen in his description of lotus. He noted there were differences but that it was "perhaps allied" with the female from Arizona that he described as lotus. He describes the abdominal maculae of this second specimen as "more oblique, and strongly concave in front" and "more convex behind" and the gena as having a "black stripe", which are characters more befitting of Snow's description of creper, which came some seven years later.

Three years before Snow formally described creper in 1895 he described specimens as pauxillus (Snow 1892). In his description of creper he synonymizes his 1892 pauxillus description with creper. Snow is also the one who suggests Williston's (1887) variety of lotus is probably creper.

In Curran's monograph (Curran 1925) he demotes S. creper from the rank of species to a variety of S. lotus. He claimed that there were no differences between the two except for the amount of interruption in the second and third abdominal bands. He believed it was just an extreme in coloration and did not warrant the rank of species. However, in the same paper he provides a redescription of lotus and based on the characters discussed and illustrated (Plate VI: 51) it is clear that his concept of lotus is not the same as Williston's and he is actually describing creper. In 1933, Fluke re-elevated creper to the rank of species. Fluke states that at that time lotus was only known from the type and that published records of lotus probably refer to creper. Fluke also notes that Curran was probably looking at specimens of creper, not lotus.

Fluke (1933) clearly distinguishes between these two species based on the abdominal markings, with lotus having more straight bands and those of creper being more arcuate. Fluke also places both species into Metasyrphus and into the amalopis group with other species currently recognized as Dasysyrphus.

Type Material: "Magdalena,/ New Mexico", "Type", blank red label, red label "Syrphus/ creper Snow/ LECTOTYPE/ Des. Vockeroth/ 1984", "Jeff Skevington/ Specimen \#/ 23782"; Ō; deposited in the Snow Entomological Museum, University of Kansas. (examined)

Material Examined:

Paralectotypes: United States of America: Colorado: Estes Park, [40.376877, -105.52137], viii.1892, đิ,

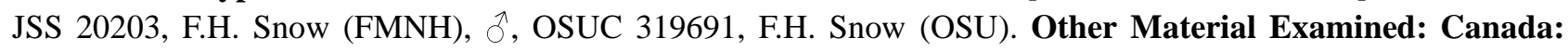
Alberta: Elkwater, Hwy 41, [49.65, -110.2666667], 7.vii.1982, + , JSS 18293, B.V. Peterson (CNC). Medicine Hat, Division No. 1, [50.040483, -110.673523], 15.v.1930, §̂, JSS 19477, F.S. Carr (CNC). Kananaskis, Forest Experimental Station Seebe, [51.100879, -115.087692], 15.vi.1968, §̋, CNCD 13634, H.J. Teskey, 20.vi.1950, + , CNCD 13643 (CNC). BANFF NATIONAL PARK: Sulphur Mountain, [51.149438, -115.583484], 2195m, 28.vii.1967,

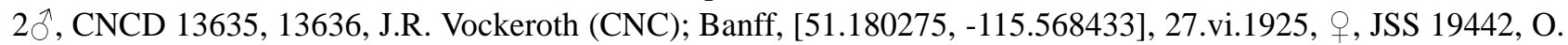

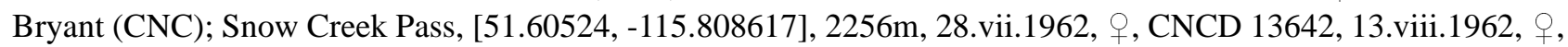
CNCD 13644, K.C. Herrmann (CNC); Peyto Lookout, [51.717631, -116.508919], 2438m, 23.vii.1962, §̃, CNCD 13630, ㅇ, CNCD 13641, K.C. Herrmann (CNC). British Columbia: CATHEDRAL PROvinCIAL PARK: Glacier Lake, [49.055785, -120.207299], 6.vii.1986, §, CNCD 13631, R.A. Cannings (CNC); 7.vii.1986, ठ̊, RBCM ENT 9881939, +, RBCM ENT 9881942, R.A. Cannings (RBCM); Quiniscoe Mtn. summit, [49.08, -120.18], 26.vii.1988, §̃, JSS 20170, S.G. Cannings (UBCZ). OKANAGAN-SiMILKAMEEN R.D.: Manning Provincial Park, Valleyview, [49.07995, -120.766842], 1830m, 14.vii.1986, §̂, JSS 18368, S.G. Cannings (CNC); Blackwall Mountain, [49.098666, -120.766925], 1828m, 7.viii.1953, Oे, CNCD 13632, D.F. Hardwick (CNC); Osoyoos, Mount Kobau, [49.111594, -119.664702], 9.vii.1968, §̃, CNCD 13627, \&, CNCD 13640, D. Allen, 13.viii.1967, J, CNCD 13628, J.R. Vockeroth (CNC); Oliver, [49.182338, -119.550442], 305m, 23.viii.1953, \&, CNCD 13637, J.E.H. Martin, 14.ix.1923, \&, CNCD 13638, C.B. Garrett (CNC); Hedley, [49.357784, -120.075962], 7.viii.1953,

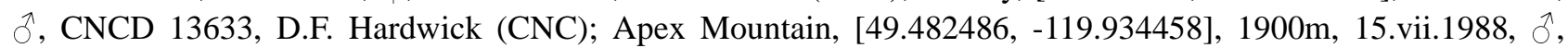
RBCM ENT 9885672, R.A. Cannings (RBCM). Robson, [49.342029, -117.697831], 22.vi.1959, +, CNCD 13639, H.R. Foxlee (CNC). Cranbrook, Elizabeth Lake, [49.497195, -115.791152], 6.vii.1980, CNCD 60067, R.A. Cannings (CNC). Mount Revelstoke National Park: Mount Harry, First Summit, [51.035979, -118.142509], 2316m, 20.viii.1952, ô, CNCD 13629, G.P. Holland (CNC). United States of America: Arizona: Rustler Park: w. Portal, [31.90556, -109.27917], 2560m, 2.viii.1977, क, USNM ENT 258093. CoCHISE Co.: [31.906851, 109.278543], 2560m, 13.ix.1965, +, JSS 19475, C.W. Sabrosky (CNC). Bradshaw Mountains, [34.41472222, 112.4038889], 1951m, 7.v.1999, ठิ, JSS 20683, R.S. Beal (CSUC). CoCONINO Co.: Oak Creek Canyon, [34.961452, -111.753046], ㅇ, CNCD 26378, F.H. Snow (CNC). Weimer Spring, [34.973632, -111.528763], 4.vi.1963, §, JSS 19445, C.H. Spitzer (CNC). Flagstaff, [35.340306, -111.670881], 3505m, 14.viii.1934, §, JSS 19435, +, JSS 19436, E.L. Bell (CNC). GRAND CANYON: North Rim [36.17849, -113.226775], 17.viii.1966, JSS 
25081, W.J. Hanson (EMUS). South Arizona, viii.1902, 29, CNCD 26379, JSS 19474, C.W. Johnson (CNC);

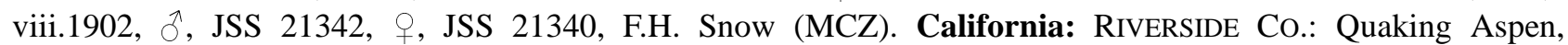
[33.69554, -117.163778], 5.vii.1984, ठ̊, JSS 18296, D.J. Burdick (CNC); San Jacinto Mountains, [33.814491, 116.679201], 9, JSS 19459, J.M. Aldrich (CNC). LOS ANGELES Co.: Westwood, [34.056121, -118.430635], 17.vi.1959, 9 , CNCD 26374, Kelton \& Madge (CNC). SAN BERNARDINO Co.: Upper Santa Ana River, [34.1003, 117.020931], 7.vii.1957, 3ð, JSS 19466-19468, 29, JSS 19438, 19465, A.L. Melander (CNC). Yosemite NATIONAL PARK: Glacier Point Road, [37.673917, -119.637698], 1.vii.1947, ㅇ, JSS 19464, A.L. Melander (CNC); Yosemite, [37.741951, -119.577767], 1183m, 26.v.1931, § , JSS 20584, (EMEC). TuOLuMNE Co.: Mather Site, Buck Meadows, [37.880173, -119.856977], 1970, ô, CNCD 26352, , CNCD 26375, A.R. Moldenke (CNC). Mono Co.: Tioga Pass, Hall Area site, [37.919391, -119.255072], 26.vii.1969, 2 , CNCD 26376, 26377, A.R. Moldenke (CNC). CALAVERAS BIG TREeS SP: Beaver Creek, [38.26166667, -120.2577778], 1375m, 22.v.11.vi.2007, $3 \hat{\text { }}$, JSS 20954-20956, + , JSS 20951, A.R. Cline \& P.H. Kerr (MHPC). Wright's Lake, [38.84944444, -120.2269444], 2120m, 20.vi.2006, Ĵ, JSS 20962, M. Hauser, S. Winterton, \& E. Fisher (MHPC). Yuba Pass, [39.323059, -120.599169], 2042m, 9.vii.1954, , JSS 20589, R.H. Goodwin (EMEC). White MounTAINS: Blanco's Corral, 3048m, 30.vi.1953, क, JSS 20590, J.W. MacSwain (EMEC). Truckee, 25.vi.1943, $3 \overbrace{}^{\lambda}$, JSS 23769, 23771, 23772, , JSS 23770, P.H. Arnaud (USNM). S. CA., v.1908, 4^, JSS 20585-20588, R. Woglum (EMEC). Colorado: SAN JUAN CO.: 10 Miles East of Silverton, [37.809565, -107.485032], 2743m, 13.viii, ô, CNCD 26351, F.M. Carpenter (CNC). Bennet Crk., [37.941103, -108.309527], 7.ix.1933, ๆ, JSS 20707 (CSUC). Garfield, [38.55185, -106.292119], 3658m, 5.viii.1971, ๆ, USNM ENT 258077, W.E. Steiner (USNM). Paonia, [38.86832, 107.592002], 16.ix.1912, JSS 20711, Chas. L. Fluke (CSUC). LAKE Co.: Independence Pass, [39.104722, 106.557321], 3688m, 31.vii.1961, ô, CNCD 26354, B.H. Poole (CNC); Tennessee Pass, [39.357246, 106.313889], 3131m, 7.vii, , JSS 19458, J.M. Aldrich (CNC). Tenmile Range, unamed Cr. avalanche chute W side, [39.425, -106.111], 3200m, 15.vii.-17.vii.1998, §̊, JSS 20682, S. Fitzgerald \& A. Foley (CSUC). Rogers Pk., [39.615821, -105.61778], 3660m, 12.vii.1997, §, JSS 20805, 10.viii.2002, ㅇ, JSS 20806, C. Slater (CSUC). ARAPAho NATIONAL Forest, MT. Evans: Mount Evans, [39.25, -106.1666667], 3658m, 3.viii.1961, ô, CNCD 26355, +, CNCD 26368, S.M. Clark (CNC); Timberline, [39.645575, -105.594897], 3566m, 22.vii.1961, q, CNCD 26367, B.H. Poole (CNC); Echo Lake, [39.659767, -105.604767], 3176m, 29.vi.2010, 2ภ, CNCD 6003360034,, , JSS 24626, M.M. Locke (CNC); Doolittle Ranch, [39.675739, -105.601348], 2987m, 10.vii.1961, $q$, CNCD 26364, 3.viii.1961, + , CNCD 26365, W.R.M. Mason (CNC). BouldER Co.: Nederland, Science Lodge, [40.031645, -105.533886], 2896m, 1.vii.1961, J, CNCD 26357, A.A. Bucknell, 28.vi.1961, q, CNCD 26361, W.R.M. Mason, 6.vii.1961, + , CNCD 26362, 1.vii.1961, + , CNCD 26363, B.H. Poole (CNC); Niwot Ridge, Near Ward, [40.069933, -105.607397], 3505m, 4.vii.1961, §̂, CNCD 26356, + , CNCD 26366, C.H. Mann, 7.vii.1965, q, JSS 19446, B. Petersen (CNC); Ward, [40.072208, -105.508332], 9.viii.1913, đ̂, JSS 20712, (CSUC). Estes Park, [40.376877, -105.52137], 8.viii.1931, + , JSS 20669, 20.v.1933, ㅇ, JSS 20671, (CSUC), viii.1892, ô, JSS 21335, F.H. Snow (MCZ). Rocky Mountain National PARK, Fall R. entrance, [40.40344, -105.589203], 4.vi.1999, ㅇ, JSS 20684, D. Leatherman, 1.viii.1997, + , JSS 20685, D. Leatherman, Manhattan, W. Rustic (CSUC). Masonville, [40.487171, -105.210056], 5.ix.1933, , JSS 20674, (CSUC). Cameron Pass, [40.520816, 118.227668], 7.vii.1931, ๆ, JSS 20709, (CSUC); 3048m, vii, ô, JSS 19981, (FMNH). Pingree Park, [40.561094, 105.597778], 20.viii.1924, + , JSS 20710, C.L. Fluke, 19.viii.1932, $\partial^{\lambda}$, JSS 20668, C.M. Drage, (CSUC), 14.viii.1934, §̃, JSS 23764, C.W.Sabrosky (USNM). LORY STATE PARK: Well Gulch Trail, [40.572996, 105.191669], 18.vi.1995, , JSS 20809, D. Leatherman (CSUC). Fort Collins, [40.58333333, -105.0833333], 19.ix.1942, $q$, JSS 20743, R.F. duChanois, 5.x.1921,, , JSS 20676, 19.ix.1932, +, JSS 20680, 21.ix.1932, + , JSS 20697, 20.ix.1932, ㅇ, JSS 20698, 8.ix.1913, ㅇ, JSS 20742, 30.ix.1942, ㅇ, JSS 20703, (CSUC). Chambers Lake, [40.603663, -105.853645], 25.vi.1932, §’, JSS 20672, 29, JSS 20675, 20701, C.R. Jones (CSUC). North Park, [40.73, -106.18], 1.vii.1932, 3 ${ }^{\uparrow}$, JSS 20695, 20696, 20705, 6우, JSS 20670, 20673, 20677, 20678, 20699, 20700, (CSUC). Glendevey, [40.8078, -105.935501], 7.vii.1932, +, JSS 20679, 3.vii.1932, Ô, JSS 20704, C.R. Jones, iv.1931, o, JSS 20708, (CSUC). HOMER, 7.ix.1934, + , JSS 20706, (CSUC). Boulder Canyon, 2377m, 8.viii.1960, , JSS 21113, R.\&K. Dreisbach (MSUC). Colorado State, 4^, JSS 19450-19453, 2q, JSS 19454, 19455 (CNC). Idaho: CUSTER Co.: 4th of July Creek, [44.39658, -114.672022], 27.vii.1975, JSS 25139, T. Griswold (EMUS). LATAH Co: Mountains Near Moscow, [46.807258, -116.868969], 9.vii.1911, §̂, CNCD 26358, + , CNCD 26373, F.M. Hull, 8.vii.1911, $q$, JSS 19470, 5.vii.1912, đૈ, JSS 19472, 6.vii.1912, + , JSS 19471, (CNC). Craig's Mountain, 29.iv.1916, + , JSS 21330, (MCZ). Holbrook, 4 mi. N.W., 16.v.1969, JSS 25080, G.F. Knowlton \& G.E. Bohart (EMUS). Montana: MISSOULA Co.: Missoula, [46.871403, -113.994267], 22.viii.1904, + , JSS 19473, 
(CNC). New Mexico: Dona AnA Co.: Las Cruces, [32.3, -106.7666667], $2 \curvearrowright$, CNCD 26359, 26360, 2 , , CNCD 26380, 26381, F.M. Hull (CNC). LINCOLN Co.: White Mountains, North Fork Ruidoso, [33.331649, -105.672958], 2499m, viii.1920, §̃, JSS 19440, Townsend (CNC). SAN Miguel Co.: Trout Spring Canyon, [35.659688, 105.34231], iv.1927, , JSS 19449, (CNC). Truchos Peak, [35.974028, -105.636663], 4.viii, ㅇ, JSS 19456, W.P. Cockerell (CNC). Embudo, Rio Arriba, [36.207523, -105.961132], 25.ix.1897, ㅇ, JSS 19441, (CNC). Las Valles, Gallinas River 3505m, 20.iv, , JSS 19437, E.L. Bell (CNC). Oregon: KALмOTH Co.: Crater Lake National Park, [42.925321, -122.172722], 10.vii.1968, , JSS 18297, B.V. Peterson (CNC). Sisters: 15 mi S, [44.060385, 121.542268], 20.vii.1976, ô, USNM ENT 258064, George Steyskal (USNM). WhitMAn NATIONL ForEST: Anthony Lake, [44.958805, -118.23057], 2164m, 28.vii.1954, ㅇ, OSAC 133387, J.H. Baker (OSAC), ô, JSS 23767, 3 , , JSS 23765, 23766, 23768, J.H. Baker (USNM), 4.viii.1929, ㅇ, OSAC 133388, H.A. Scullen (OSAC). South Dakota: LAwrenCE Co.: Spearfish Creek, [44.589399, -103.886595], 14.vi.1969, §ै, JSS 19476, W.W. Wirth (CNC). HARDY W.C.: T3N, R1E, S30, 3.vii.1965, J, CNCD 5445, R.W. Hodges (USNM). Utah: GARFIELD Co.: Henry Mountains, [38.028415, -110.712679], 2286m, 29.vii.1968, đ̃, JSS 18295, J.E.H. Martin (CNC). WAYNE CO.: Capitol Reef National Park, [38.177815, -111.176958], 3.x.1984, JSS 25137, W.P. Nye (EMUS). DUCHESNE Co.: Mirror Lake, [38.31073, -112.367492], 2743m, 21.vii.-9.viii.1977, JSS 25135, 2.viii.1971, JSS 25138, G.F. Knowlton (EMUS). Box ELDER Co.: Willard Basin, [41.394101, -111.973766], 2743m, 26.viii.1964, JSS 25134, W.J Hanson (EMUS). CACHE Co.: Tony Grove Creek, [41.886599, -111.564102], 10.viii.1976, JSS 25136, (EMUS); Green Canyon M.T., 31.viii.2003-25.viii.2003, ๆ, JSS 24611, W.J. Hanson \& Brammer (EMUS). DAGGETT Co.: Rt. 44, 2438m, 10.vii.1962, + , JSS 21110, R.\&K. Dreisbach (MSUC). SUMMIT Co.: Henry’s Fork Pk., 2926m, 1.viii.1979-10.viii.1979, , CNCD 5807, S. \& J. Peck (CNC). Washington: Mount Adams, [46.204174, -121.493902], 3.viii.1930, ᄋ, JSS 19460, F.P. Dean (CNC). Mt. Ranier, White River, [46.782709, 121.727952], 20.vii.1924, Ỏ, JSS 23763, A.L. Melander (USNM). SPOKANE Co.: Buckeye, [47.842393, 117.374385], 21.vi.1930, ô, JSS 19444, J.M. Aldrich (CNC); Mount Spokane, [47.923711, -117.111646], 22.vi.1930, + , JSS 19457, 27.vi.1930, + , JSS 19448, 2.vii.1930, + , JSS 19447, J.M. Aldrich (CNC). Wawawai, 28.v.1922, $\hat{\jmath}$, JSS 23762, A.L. Melander (USNM). Wyoming: AlbANy Co., [41.727896, -105.684712], 2.viii.1927, Ô, CNCD 26353, C.L. Corkins (CNC). Camp Guernsey, Ryan Springs, [42.260113, -104.728624], 31.v.2005, đ̂, JSS 20686, B. Kondratieff, J. Schmidt, J. Owens (CSUC). Yellowstone National Park: Jet Lake, [44.550878, -110.808744], 16.viii.1927, +, JSS 19439, J.M. Aldrich (CNC); Canyon Village, [44.587719, 110.537673], 21.vii.1971, 今, CNCD 5444, G.C. Steyskal (USNM); Canyon Campground, [44.733262, 110.486225], 12.viii.1918, Ô, JSS 19461, + , JSS 19462, A.L. Melander (CNC); Mount Washburn [44.797716, 110.434368], §ै, JSS 21343, C.T. Brues (MCZ). Centennial: 23.viii.1951, 2 , , JSS 21109, 21111, R.R. Dreisbach (MSUC); Snowy Range, 3048m, 8.ix.1950, 2 q, JSS 21105, 21114, R.R.D. \& R.K. Schwab, 23.viii.1951, §, JSS 21108, 2 9 , JSS 21106-21107, R.R. Dreisbach (MSUC). Wyoming, 1952, 4 + , CNCD 26369-26372, F.M. Hull (CNC).

\section{Dasysyrphus intrudens species complex (Osten Sacken)}

Figures: 7A-F, 20B

Synonyms and References:

Syrphus amalopis Osten Sacken 1875: 148 (in part, description)

Syrphus intrudens Osten Sacken 1877: 326 (original description)

Syrphus amalopis Osten Sacken:

Williston 1887: 69 (in part; redescription)

Syrphus disgregus Snow 1895: 233 (original description; comb. nov.) Curran 1925: 180 (discussion)

Syrphus laticaudatus Curran 1925: 176, Pl. XI Fig. 152 (original description; comb. nov.)

Syrphus osburni Curran 1925: 177, Pl. XI Fig. 153 (original description; comb. nov.)

Metasyrphus amalopis (Osten Sacken):

Fluke 1933: 110 (in part, includes disgregus and intrudens; key, redescription and transfer to Metasyrphus)

Metasyrphus laticaudatus (Curran):

Fluke 1933: 111 (key, redescription and transfer to Metasyrphus)

Metasyrphus osburni (Curran):

Fluke 1933: 112 (key, redescription and transfer to Metasyrphus)

Dasysyrphus amalopis (Osten Sacken): 
Stone et al. 1965: 563 (in part; includes intrudens, catalogue and move to Dasysyrphus)

Dasysyrphus disgregus (Snow):

Stone et al. 1965: 563 (catalogue and move to Dasysyrphus)

Dasysyrphus laticaudatus (Curran):

Stone et al. 1965: 563 (catalogue and move to Dasysyrphus)

Dasysyrphus osburni (Curran):

Stone et al. 1965: 564 (catalogue and move to Dasysyrphus)

Dasysyrphus venustus (Meigen):

Vockeroth 1986: 203 (in part, includes disgregus, intrudens, laticaudatus and osburni; lectotype designation for disgregus and intrudens and discussion)

Vockeroth 1992: 70 (in part, includes intrudens, disgregus, laticaudatus and osburni; key and redescription)

Diagnosis: Abdominal maculae cross abdominal margin; maculae on tergite 2 large (>1/3 width of tergite) ovalshaped; maculae on tergites $3 \& 4$ arcuate or lunulate, usually strongly constricted medially, sometimes dividing maculae in half, with medial edge swollen, never meeting medially, maculae reach abdominal margin, usually broadly contacting edge of abdomen (Figs 7A-E). Has previously been confused with D. venustus, however, species in this complex have maculae that are arcuate, lunulate and/or greatly constricted medially, whereas in $D$. venustus they are more transverse and much less constricted medially (Fig. 17A).

Redescription:

Body Length: $7.0-11.7 \mathrm{~mm}$; Wing Length: $7.0-10.7 \mathrm{~mm}$

Head: Frons dark with light pollenose fascia (in males it runs along ventral edge of where eyes meet, in females it is $1 / 4-1 / 2$ the length between the antennae and ocelli and narrowly to widely separated medially) and dark pile; face light with dark vitta $1 / 4-1 / 2$ the width of the face, usually reaching antennal socket, face with dark or light pile, sometimes with a both light and dark pile; gena dark with light pile; occiput dark, covered in light pollen, pile light; scape and pedicel light to dark, flagellomere usually light basally and darker apically, sometimes mostly dark.

Thorax: Scutum dark, may appear shiny or metallic, pile light; scutellum light with darker anterolateral edges, light pile some with varying amounts of dark pile posteriorly; cell c usually densely microtrichose but sometimes bare basally, $r_{1}$ is usually bare at the base, but can be entirely microtrichose, br and bm range from densely microtrichose to extensively bare, but often with some bare areas, cup either densely microtrichose or bare at base and/or along CuP; haltere light; pro- and mesofemora $1 / 3-1 / 2$ dark basally, $1 / 2-2 / 3$ light apically, metafemur $2 / 3-3 / 4$ dark basally, $1 / 4-1 / 3$ light apically, tibiae light, metatibia and rarely pro- and/or mesotibiae with dark band $1 / 4$ of the way from the apex, tarsi light, sometimes dark anteriorly.

Abdomen: Maculae on tergite 2 large and oval, sometimes with anterolateral edge extending to edge of abdomen, maculae on tergites $3 \& 4$ arcuate or lunulate, usually strongly constricted medially, sometimes dividing maculae in half, with medial edge swollen, never meeting medially, maculae reach abdominal margin, usually broadly contacting edge of abdomen (Figs 7A-E); sternite 2 either all light, with dark oval macula or with dark fascia (usually distinct, sometimes faint), sternites $3 \& 4$ light with dark fasciae.

Male Genitalia: Surstylus more or less triangular in shape in lateral view, flattened anteroposteriorly with long pile on posterior side and spines on anteroventral side, similar to D. venustus (Fig. 17D) and D. limatus (Fig. 9D); cercus oval with long pile over entire surface; gonostylus is pointed ventrally, dorsally flattened at base then it expands dorsally towards apex, oblique ridge near apex, with ends of ridge projecting into points; pile on dorsal surface; basiphallus is basally bent at about a 90 degree angle towards the dorsum, at apical end it is curved ventrally, fully sclerotized all the way around with no pile or spines; distiphallus is long with no enlarged area basally, shaft sometimes with small bump dorsally near base, apical end flared out into horn with the dorsal side flattened slightly, which is mostly sclerotized but membranous at apex with setulae dorsally (Fig. 7F).

Intraspecific variation: The abdominal maculae are highly variable (Figs 7A-E), likely because multiple, unresolved species lie within this complex. Tergites $3 \& 4$ have maculae that can be arcuate or lunulate, usually strongly constricted medially, sometimes dividing maculae in half, medial edge swollen but degree of swelling varies, maculae usually broadly contact edge of abdomen, but in few specimens they end just past margin and do not contact edge; sternite 2 colouring variable, either all light, with dark oval macula or with dark fascia (usually distinct, sometimes faint); wing cells vary in microtrichia density with $\mathrm{c}$ usually densely microtrichose but sometimes bare basally, $\mathrm{r}_{1}$ is usually bare at the base, but can be entirely microtrichose, br and bm range from densely microtrichose to extensively bare, but often with some bare areas, cup either densely microtrichose or bare at base and/or along $\mathrm{CuP}$; distiphallus shaft sometimes with small bump dorsally near base. 


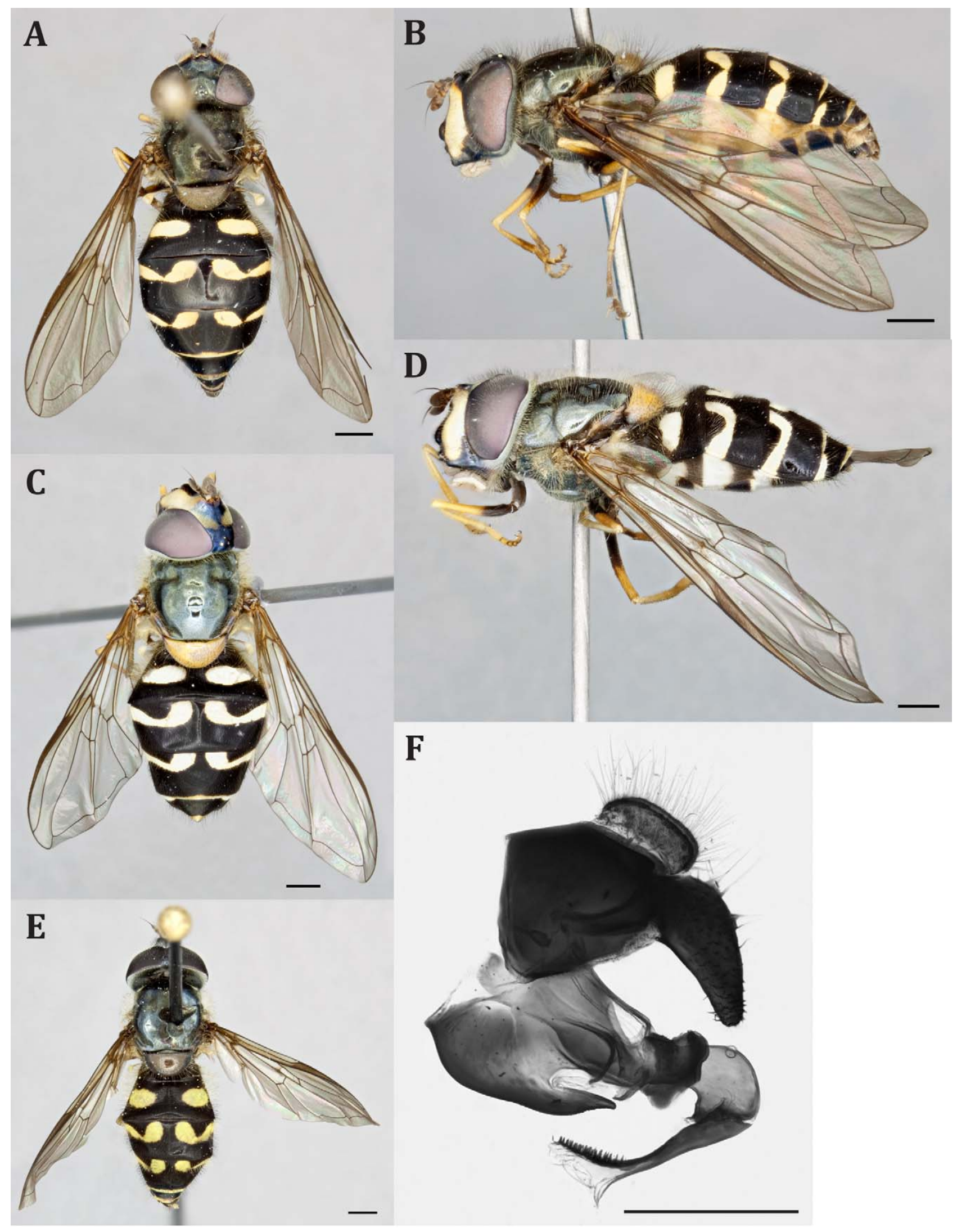

FIGURE 7. Dasysyrphus intrudens complex: A: female (CNCD 14312) dorsal habitus; B: female (CNCD 14312) lateral habitus; C: female (CNCD 30911) dorsal habitus; D: female (CNCD 30911) lateral habitus; E: male (JSS 23704) dorsal habitus; F: lateral view of male (CNCD 30894) genitalia. Dorsal and lateral habitus scale bar $=1 \mathrm{~mm}$, genitalia scale bar $=$ $500 \mu \mathrm{m}$. 
Etymology: Presumably comes from the Latin, intrudo, meaning enter without invitation or permission.

Distribution: Canada (AB, BC, NF, NS, ON QC, YT) and US (AK, AZ, CA, CO, ID, MA, MD, ME, MI, NC, NH, NM, NY, OR, PA, TN, UT, VA, WA, WV, WY), also widespread over Europe and Asia (Fig. 20B)

Ecology: Collected on great camas (Camassia leichtlinii (Baker) S. Watson, Liliaceae), common camas (Camassia quamash (Pursh) Greene, Liliaceae), Carolina spring beauty (Claytonia caroliniana Michaux, Portulacaceae), small-flowered woodland-star (Lithophragma parviflorum (Hooker) Nuttall ex Torrey \& A. Gray, Saxifragaceae), heart-leaved foamflower (Tiarella cordifolia Linnaeus, Saxifragaceae), birch (Betula Linnaeus, Betulaceae), common cowparsnip (Heracleum maximum W. Bartram, Apiaceae), cowparsnip (Heracleum Linnaeus, Apiaceae), blackberry (Rubus Linnaeus, Rosaceae), Pacific blackberry (Rubus ursinus Chamisso \& Schlechtendal, Rasaceae), Pacific silver fir (Abies amabilis (Douglas ex Loudon) Douglas ex J. Forbes, Pinaceae), Labrador tea (Ledum Linnaeus, Ericaceae), spotted-water hemlock (Cicuta maculata Linnaeus, Apiaceae), blueberry (Vaccinium Linnaeus, Ericaceae), dogwood (Cornus Linnaeus, Cornaceae), jack pine (Pinus banksiana Lambert, Pinaceae), mountain maple (Acer spicatum Lamarck, Aceraceae), nannyberry (Viburnum lentago Linnaeus, Caprifoliaceae), beachgrass (Ammophila Host, Poaceae), herb-Robert (Geranium robertianum Linnaeus, Geraniaceae), slender phlox (Microsteris gracilis (Hooker) Greene, Polemoniaceae), spreading groundsmoke (Gayophytum diffusum subsp. parviflorum F.H. Lewis \& Szweykowski, Onagraceae), chokecherry (Prunus virginiana, Rosaceae), bristly bearberry (Arctostaphylos columbiana Piper, Ericaceae), slender stitchwort (Minuartia tenella (J. Gay) Mattfeld, Caryophyllaceae), hairy cat's ear (Hypochaeris radicata Linnaeus, Asteraceae). Habitats listed on labels include "Ainus-Populus-Picea" or "Alder-Poplar-Spruce", "along creek in forested ravine", "along roadside", "Betula woods", "birch \& fir", "black spruce forest", "canopy gap in hardwood forest", "dry sand beach ridge", "gap in Mh/Be forest", "hardwood forest", "hemlock forest", "hot springs", "in clearing near river", "Ledum-Kalmia bog", "low vegetation and leaf litter at campsite", "marshy meadow", "on tide flats", "Picea forest", "pine forest", "Pinus-Salix forest", "riverbank scrub", "Salix-Picea", "scrub poplar and low vegetation", "seepage area", "fen", "sphagnum bog", "Vaccinium wood" and "wet, scrubby clearing". This species complex is also collected from hilltops. Collected January to November, although much more frequently collected in May to August. Collected from elevations from sea level-4000m.

Discussion: Dasysyrphus intrudens is most certainly a complex of multiple species. However, the boundaries between these species are still unclear. The COI clusters produced in the NJ tree (Fig. 4) yielded no clues to the number of species existing in this clade. When sorting the specimens by barcodes, no consistant morphological patterns were visible. Sometimes characters were similar between two or more clusters and sometimes within one cluster there were multiple character states. As the barcoding region of COI appears to be of little help to sort this complex into species, other markers should be sequenced to look for insight into species boundaries. Fresh material collected into absolute alcohol will be required to sequence the necessary genes.

Note that this group has been referred to as the friuliensis group in conference abstracts, but never in a refereed publication. The oldest group name, intrudens, best serves as the name for the complex.

Type Material: "Lagunitas Creek, Cal./ April 15. O. Sacken", "Osten/ Sacken/ Coll.", red label "Type/ 875", yellow label "LECTOTYPE/ Syrphus/ intrudens O.S./ Desig. Thompson 1977", "Syrphus/ intrudens O.S.", J. Skevington/ Specimen \#/ 23783", Ô, deposited in the Museum of Comparative Zoology, Harvard University (MCZ). Both basoflagellomeres and right metaleg missing. Genitalia have been removed at some point and are not associated with the specimen (presumed to be lost). (examined)

Material Examined: There were 2138 specimens from throughout the Nearctic (Fig. 20B) that were examined for this study. Because this is a complex and species boundaries need to be resolved, it is of little use to list all information for material examined. Database records for each specimen examined may be obtained from the authors.

\section{Dasysyrphus laticaudus (Curran)}

Figures: 8A-E, 20C

Synonyms and References:

Syrphus laticaudus Curran 1925: 175, Pl. XI Fig. 151 (original description)

Metasyrphus laticaudus:

Fluke 1933: 117 (key, redescription and transfer to Metasyrphus) 
Dasysyrphus laticaudus:

Stone et al. 1965: 563 (catalogue and transfer to Dasysyrphus)

Vockeroth 1986: 203 (synonymized under pauxillus)

Vockeroth 1992: 68 (key and redescription)

Diagnosis: Maculae oblique and fairly uniform in thickness. Like D. pauxillus, D. pacificus and D. nigricornis, maculae on tergites $3 \& 4$ do not reach edge of abdominal margin (Figs 8A, B \& D). Dasysyrphus laticaudus differs from the other three in that the markings on tergite 2 in the female extend anterolaterally to the edge of the abdomen (Fig. 8B) and in the male they extend similarly, sometimes only slightly, but usually do not reach the edge (Fig. 8D). Maculae on tergites $3 \& 4$ usually come very close to the margin, if not narrowly touching it, but never crossing it (Figs 8A, B \& D).

Redescription:

Body Length: 5.0-8.2mm; Wing Length: 4.8-7.8mm

Head: Frons dark with light pollenose fascia (in males it runs along ventral edge of where eyes meet, in females it is $1 / 3-1 / 2$ the length between the antennae and ocelli with a separation medially and edges triangular to rounded) and dark pile, some females with light pile; face light with dark vitta $1 / 4-1 / 3$ the width of the face, usually coming close but not reaching antennal socket, face with dark pile lateral to the eye, shorter in females; gena dark with light to dark pile; occiput dark, covered in light pollen, pile light; scape and pedicel light to dark, flagellomere usually dark with light base.

Thorax: Scutum dark, may appear shiny or metallic, pile variable, from all light to variable to all dark; scutellum light to dark with darker lateral edges, pile on female mostly light with some dark, male typically with dark pile, but sometimes with some light pile anteriorly; wings densely microtrichose, some with small bare areas in br above the base of the spurious vein (Fig. 8E); haltere light; profemur $1 / 4-1 / 3$ dark basially, $2 / 3-3 / 4$ light apically, mesofemur $1 / 3-1 / 2$ dark basially, $1 / 22^{2} / 3$ light apically in males, pro-and mseofemora of females are light, base may be slightly darkened (Fig. 8B), metafemur $2 / 3-3 / 4$ dark basially, 1/4-1/3 light apically, tibiae light, metatibia with dark band $1 / 4$ of the way from the apex, sometimes extending to apex, tarsii light, sometimes dark anteriorly.

Abdomen: Maculae on tergite 2 large and oval, in female the anterolateral edge reaching the edge of the tergite (Fig. 8B), in males there is a small projection but it terminates before the edge (Fig. 8D), maculae on tergites $3 \& 4$ are oblique fairly straight and of uniform thickness, maculae do not reach abdominal margin (Figs 8A, B \& D); sternites light with dark fasciae of varying thickness.

Male Genitalia: Surstylus more or less triangular in lateral view, flattened posteriorly, long pile on dorsal, laterodorsal and posterodorsal sides, row of spines on posteromedial edge; cercus oval with long pile over entire surface; gonostylus boot-shaped but slightly more narrow apically than basally, with projection on posterodorsal surface, projecting dorsally, pile on dorsal surface; basiphallus elongate, basally bent at a slightly more than 90 degree angle towards dorsum, apical end curved ventrally, but does not greatly extend ventrally and is partly membranous dorsally, with spines on posterodorsal side; distiphallus elongate, apical end flared out into horn, which is mostly sclerotized but membranous at apex, with no setulae dorsally, basally bent towards dorsum and usually greatly enlarged at bend with a triangular projection, projecting ventrally (Fig. 8C). Extremely similar to $D$. pauxillus (Fig. 14D).

Intraspecific Variation: Female maculae on tergite 2 tend to be similar across individuals, however on males, the extent of projection on the anterolateral edge can vary. Male femora are always dark basally and light apically. Many females have predominantly light femora (especially the profemur; Fig. 8B). Females from the northwestern part of the range (Yukon) have femora that are dark basally and light apically. Wing cells are usually densely microtrichose, but sometimes have very small bare areas in cell br, above the spurious vein. Basal horn of distiphallus occasionally has few minute setulae dorsally.

Etymology: Comes from the Latin words latus, meaning broad and cauda, meaning tail.

Distribution: Eastern and northern Canada (MB, NB, NT, NS, NU, ON, QC, YK) and northeastern and northern USA (AK, CT, ME, MA, MI, NH, NY). (Fig. 20C)

Ecology: Collected from April-July, but more commonly in June and July. Collected at elevations of 792 $1067 \mathrm{~m}$. Habitats this species has been collected from, according to label data, are "Mh/Be forest" (mixed hardwood/beech), "hardwood forest", "mixed forest", "pine forest", "coniferous woods", "at top of limestone bluff" and "top of open S-facing bluff". It has been recorded as being collected on pine trees (Pinus Linnaeus; Pinaceae). 


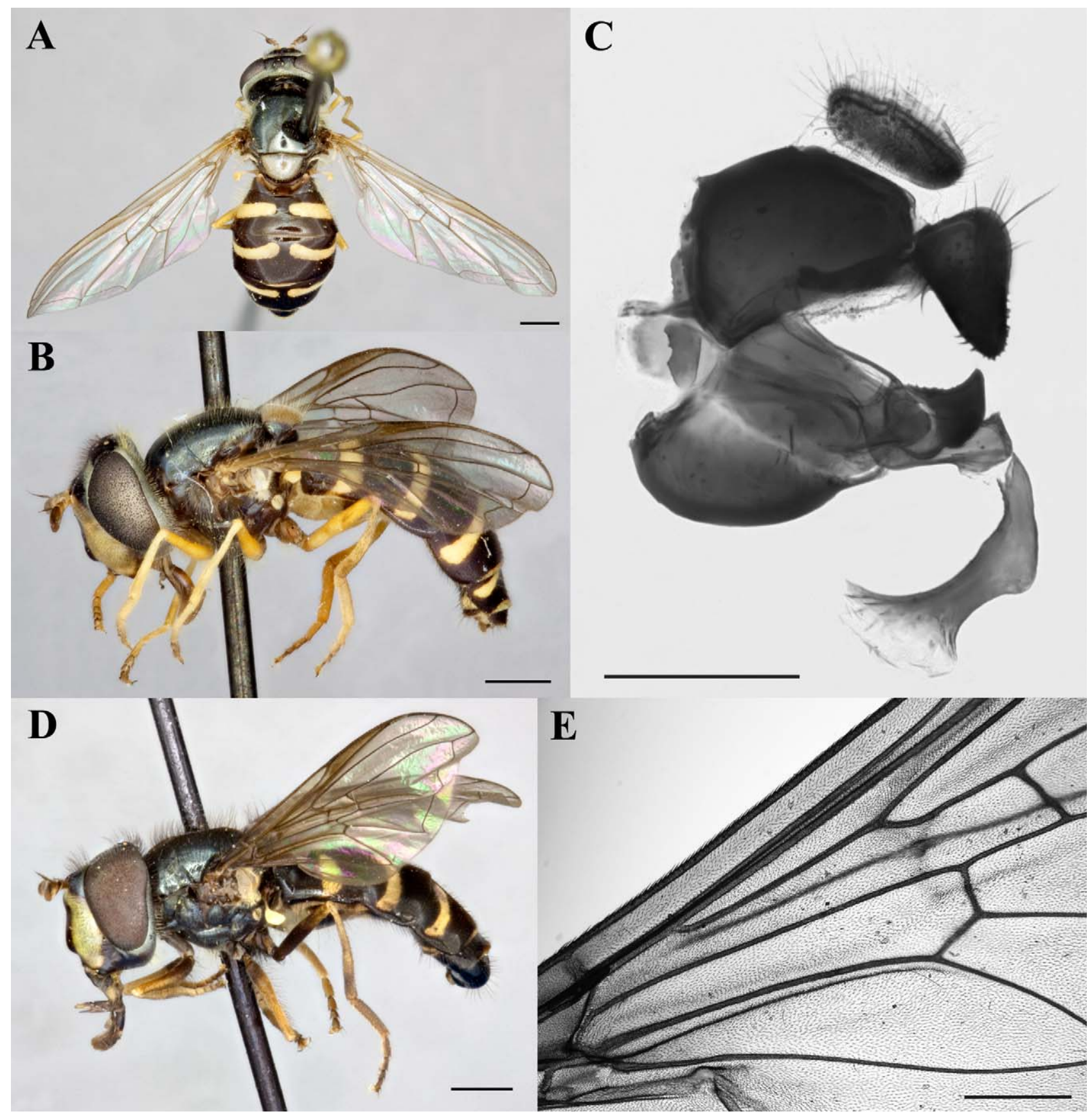

FIGURE 8. Dasysyrphus laticaudus: A: female (CNCD 13875) dorsal habitus; B: female lateral (CNCD 13875) habitus; C: lateral view of male (CNCD 30087) genitalia; D: male (JSS 20763) lateral habitus; E: wing base (JSS 24614). Dorsal and lateral habitus scale bar $=1 \mathrm{~mm}$, genitalia and wing scale bar $=500 \mu \mathrm{m}$.

Discussion: Dasysyrphus laticaudus is hereby resurrected from synonymy with Dasysyrphus pauxillus (synonymized by Vockeroth (1986)). Vockeroth (1986) considered them to be the same species, presumably with only slight morphological differences between the species being mistaken for intraspecific variation. Dasysyrphus laticaudus is very similar to pauxillus (Figs 14A \& B) and pacificus (Figs 13A \& B), with the later two being extremely difficult to distinguish from each other. There are however, morphological and genetic characters that distinguish laticaudus from pauxillus and pacificus. Their distributions are also predictable and largely nonoverlapping.

Type Material: "Orillia Ont/ 5.v.1921”, "Collector/ H. Curran”, red label "HoloTYPE/ Syrphus/ laticaudus/

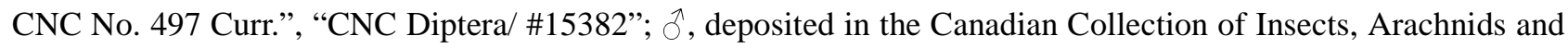
Nematodes (CNC), Ottawa, ON. (examined) 
Material Examined:

Paratypes: Canada: Ontario: SIMCOE Co.: Orillia, [44.609505, -79.42068], 4.v.1921, + , CNCD 13851, 5.v.1921, O , CNCD 13885, H. Curran (CNC). Other Material Examined: Canada: Manitoba: Winnipeg, [49.88333333, -97.13333333], 20.vii.1948, §̂, JBWM 206845, W.H. Fell, 24.v.1949, +, JBWM 206517, C.F. Barrett (JBWM). New Brunswick: CHARLOTTE Co., [45.23102, -66.925304], 9.vi.1955, + , CNCD 13909, W.T.A.

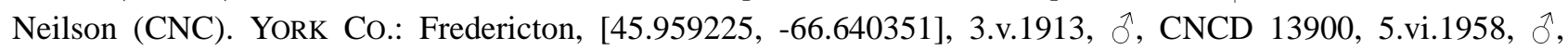
CNCD 13901, (CNC). Sackville, [45.998, -64.3591], 7.v.2010, Ô, JK 969, J. Klymko, S.L. Robinson, D.M.Mazerolle (NBMB). KENT Co.: Kouchibouguac National Park, [46.819201, -64.96788], 19.v.1977, đૈ, JSS

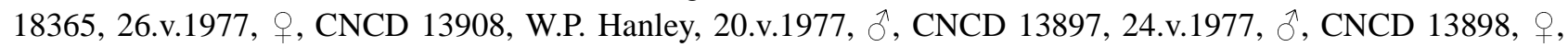

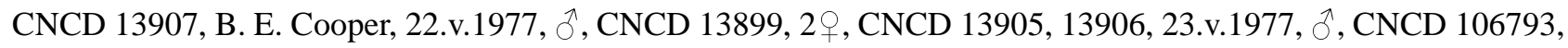
Hanley \& Cooper, 23.v.1977, Ô, JSS 18364, J.D. Lafontaine (CNC). Northwest Territories: Wholdaia Lake, [60.680702, -104.293128], 2.vii.-4.vii.1966, +, CNCD 13779, J.G. Chillcott (CNC). 21 miles east Tuktoyaktuk, [69.426844, -132.172475], 20.vi.1971-25.vi.1971, , , CNCD 13773, D.M. Wood (CNC). Nova Scotia: INVERNESS Co., Cape Breton Highlands National Park, Pleasant Bay, [46.822961, -60.799065], 9.vi.1984, CNCD 60066, 12.vi.1984, + CNCD 13904, B.E. Cooper (CNC). Nunavut: Ford Lake, M.T.S. Gravity Survey Camp, [63.133386, -107.416561], 28.vi.1966, 3ð , CNCD 13716-13718, G.E. Shewell (CNC). Ontario: KaWARTHA LAKES Div., Fenolon Falls, [44.538149, -78.735433], 27.v.1927, ㅇ, CNCD 13856, F.P. Ide (CNC). Chaffeys Locks, [44.56666667, -76.31666667], 15.v.1975, §, ROMEnt Spec. No. 115136, J.C.E. Riotte (ROME). HASTINGS Co., Maynooth, [45.229716, -77.940949], 25.v.1951, +, CNCD 13857, J.F. McAlpine, 22.v.1970, 2ð, CNCD 13883, 13884, D.M. Wood, 10.v.1987, CNCD 60346, D. Bell \& M. Wood (CNC). Griffith, 7 miles East, [45.243279, -77.031193], 31.v.1983, + , CNCD 13858, B.E. Cooper (CNC). AlgONQuin PRovincial Park: Cranjelly Lake, [45.28719, -78.28012], 7.v.-21.v.2009, JSS 22433, 22435, 21.v.-4.vi.2009, JSS 22436, E. Proctor (CNC); Madawaska Lake, [45.3261, -78.3056], 12.v.-27.v.2007, 20, JSS 20747, 21358, 9.vi.-24.vi.2008, JSS 22430, 24717, 24718, 15.v.-29.v.2009, JSS 22434, 7.vi.-21.vi.2008, JSS 24719, 1.v.-15.v.2009, JSS 22431, E. Proctor (CNC); Crossbar Lake, [45.32686, -78.29997], 15.v.-29.v.2009, đ̃, JSS 24614, 22432, E. Proctor (CNC); Florence Lake [45.44371, -78.49012], 13.v.-29.v.2007, đ, JSS 21353, 19.v.-3.vi.2009, JSS 22437, E. Proctor (CNC); Sitting Duck Lake, [45.44985, -78.46831], 21.v.-21.v.2008, JSS 24643, E. Proctor (CNC); Cecil Lake, [45.4511, -78.4956], 6.vi.-20.vi.2008, JSS 25250, E. Proctor (CNC); Pondweed Lake, [45.46488, -78.43066], 6.vi.-19.vi.2008, JSS 23709, 26.v.-9.vi.2009, JSS 22441, 16.v.-28.v.2007, 2 9, JSS 21354, 21355, 9.v.-16.v.2007,

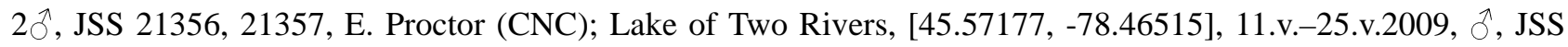
24613, 11.v.2009, JSS 22440, 11.v.2009-25.v.2009, JSS 22438, 22439, E. Proctor (CNC); Kearney Lake Campround, [45.57267, -78.439397], 11.vi.2005, ㅇ, JSS 19761, L. Bartels (CNC); Lake Sasajewun, [45.58, 78.36], 19.v.1965, Ô, ROMEnt Spec. No. 115125, S.M. Smith (ROME); Brewer Lake, [45.58551, -78.31044], 18.v.2009-2.vi.2009, JSS 22442, E. Proctor (CNC); Algonquin Park, 11.vi.2003-18.vi.2003, §, ROMEnt Spec. No. 98519, , ROMEnt Spec. No. 98518, Mark Vanderwel (ROME). Ottawa, Stack Road, [45.320852, 75.736188], 7.v.2007, 60, CNCD 30882-30887, J.R. Vockeroth (CNC). Constance Bay, [45.495933, 76.08694444], 18.iv.2010, §, JSS 19757, J. Skevington (CNC). CoCHRANE DIST,: Low Bush, Lake Abitibi, [48.91608, -80.139852], 7.vi.1925, + , CNCD 13852, 9.vi.1925, क, CNCD 13853, 14.vi.1925, + , CNCD 13854, 16.vi.1925, +, CNCD 13855, N.K. Bigelow (CNC); 9.vi.1923, UASM\# 149023, N.K. Bigelow (UASM); 6.vi.1925, BOC 34683, 7.vi.1925, , BOC 34684, 9.vi.1925, 2 + , BOC 34685, 34686, 13.vi.1925, , BOC 34687, 16.vi.1925, 2甲, BOC 34688, 34689, 24.vi.1925, ㅇ, BOC 34690, N.K. Bigelow (ROME); 14.vi.1925, , JSS 21337, 15.vi.1925, + , JSS 21338, N.K. Bigelow (MCZ). Almonte, 18.v.1951, §̊, CNCD 106791, J.F. McAlpine (CNC). Quebec: OUTAOUAIS: Aylmer, [45.400224, -75.817137], 28.v.1923, 2 \%, CNCD 13866, 13867, 29.v.1923,

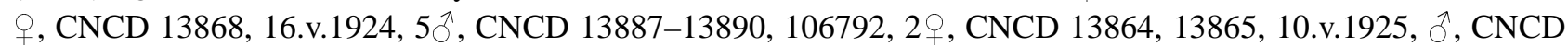
13886, C.H. Curran (CNC); Hull, [45.447639, -75.733192], 26.v.1923, 4 , CNCD 13859-13862, 24.v.1923, $q$, CNCD 13863, 14.v.1924, 2 , CNCD 13891, 13892, C.H. Curran (CNC); 27.v.1923, ๆ, BOC 34691, C.H. Curran (ROME); Beechgrove, [45.64508, -76.123602], 15.v.1951, +, CNCD 13874, 3.v.1968, §ึ, CNCD 13894, +

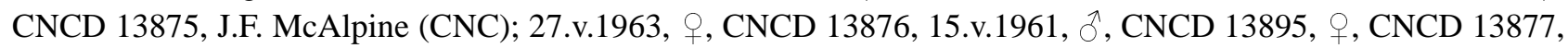
J.R. Vockeroth (CNC). VAudREUIL-SoulangeS: Mount Rigaud, [45.466534, -74.325875], 13.v.2008, §, JSS 17647, J. Skevington, J. Gibson, A. Sugarman (CNC); 1.v.1986, Oૈ, JSS 18342, B.E. Cooper (CNC); 10.v.1986, 3ึ, JSS 20763-20765, B.E. Cooper (CNC). Duncan Lake, near Rupert, [45.68138889, -76.05027778], 5.vi.1971, + , CNCD 13881, J.F. McAlpine (CNC). LE CENTRE-DE-LA-MAURICE: Lac Mondor, Near Ste. Flore, [46.625254, - 


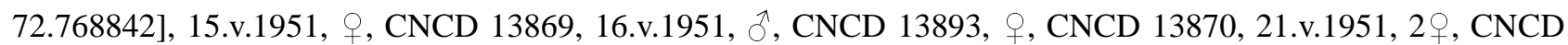
13871, 13872, E.G. Munroe (CNC). LA HAUTE-GASPESIE: Mont Albert, [49.131813, -66.464367], 1067m, 1.vii.1954, §̊, CNCD 13896, W.J. Brown (CNC). Rupert River, [51.483333, -78.766667], 19.vi.1956,, , CNCD 13878, J.R. Lonsway (CNC). SEPT-RIVIERES-CANIAPISCAU: $37 \mathrm{~km}$ North West of Schefferville, [55.038335, 66.424521], 12.vi.1981, +, CNCD 13880, F. Brodo (CNC). Great Whale River, [55.116816, -76.405554], 7.vii.1949, + , CNCD 13882, J.R. Vockeroth (CNC). Yukon Territory: $10 \mathrm{~km}$ North of Carcross on Highway 2, [60.2596, -134.749909], 5.vi.1981, +, JSS 18373, C.S. Guppy (CNC). Bluefish Ridge, [67.15, -140.6166667], 792m, 2.vii.1983, 2q, JSS 20049, 20050, 7.vii.1983, +, JSS 20069, R.J. Cannings (UBCZ). 6 km East of Old Crow, [67.566667, -139.683333], 13.vii.1981, +, JSS 18366, C.S. Guppy (CNC). Old Crow, [67.571219, 139.833877], 4.vii.1983, JSS 20071, R.A. Cannings (UBCZ); 13.vii.1981, CNCD 60075, C.S. Guppy (CNC). Firth River, [69.207056, -140.071033], 22.vi.1984, +, JSS 18375, S.G. Cannings (CNC). United States of America: Alaska: MATANUSKA-SUSitnA COUNTY: Matanuska, [61.541945, -149.229674], 12.vi.1944, q, JSS 19515, J. Chamberlin (CNC). Connecticut: New London CounTy: Lyme, [41.400831, -72.342951], 4.v.1918, §ิ, JSS 19491, C.T. Greene (CNC). Maine: Aroostook CounTY: Crystal, [45.95953, -68.361018], vi.1980, §, CNCD 26441, S.N. Pease (CNC). Maryland: PRINCE GEORGE's COUNTY: Laurel, [39.101761, -76.860489], 25.v.1965, ô, CNCD 26728, (CNC). Massachusetts: WORCESTER COUNTY: Sunderland, [42.244545, -71.77175], 15.v.1965, ô, JSS 19492, F.C. Thompson (CNC). HAMPSHIRE COUNTY: Amherst, [42.34038, -72.496818], 3.v.1963, 4^, JSS 19493-19496, 7.v.1963, đ̂, JSS 19497, 14.v.1963, §̂, JSS 19498, F.C. Thompson (CNC). Michigan: CRAWFORD CO.: 27.v.1958, + , JSS 21151, 21152, R. \& K. Dreisbach (MSUC). New Hampshire: CHESHIRE CO.: Jaffrey, [42.814957, -72.022399], 4.vi.1919, क, CNCD 26424, C.W. Johnson (CNC). Glen House, [44.289163, 71.225764], 14.vi.1911, + , JSS 21339, N.K. Bigelow (MCZ). Mt. Monadnock, 11.vi.1932, , JSS 23773, A.L. Melander (USNM). New York: ToMPKINS Co.: Ithaca, [42.444589, -76.499268], 11.v.1898, + , CNCD 26425, C.W. Johnson (CNC); ESSEX Co.: Corlear Bay, Lake Champlain, [44.483961, -73.418207], vi.1939, $\uparrow$, JSS 19499, R.C. Shannon (CNC).

\section{Dasysyrphus limatus (Hine)}

Figures: 9A-D, 20D

Synonyms and References:

Syrphus limatus Hine 1922: 146 (original description) Curran 1925: 178, Pl. XI Fig. 154 (redescription)

Metasyrphus limatus:

Fluke 1933: 114 (key, redescription and transfer to Metasyrphus)

Dasysyrphus limatus:

Stone et al. 1965: 563 (catalogue and transfer to Dasysyrphus)

Vockeroth 1986: 202 (lectotype designation)

Vockeroth 1992: 66 (key and redescription)

Diagnosis: Abdominal maculae cross abdominal margin; maculae on tergite 2 very small oval-shaped; maculae on tergites $3 \& 4$ transverse, narrow and slightly widened medially, narrow slightly towards margin (Fig. 9A). Similar to D. venustus (Fig. 17A) however the maculae on tergite 2 are always small in D. limatus, less than $1 / 4$ the width of the tergite, and are much larger in D. venustus, greater than $1 / 3$ the width of the tergite.

Redescription:

Body Length: 7.5-10.9mm; Wing Length: $6.8-10.4 \mathrm{~mm}$

Head: Frons dark with light pollenose fascia (in males it runs along ventral edge of where eyes meet, in female it is $1 / 2$ or less the length between the antennae and ocelli, with a distinct separation medially) and dark pile; face light with dark vitta $1 / 3-1 / 2$ the width of the face and reaches the antennal socket, face with dark pile, bare medially; gena dark with some light pollen ventral to eye, light and dark pile; occiput dark, covered in light pollen, pile light, some specimens with some dark pile; scape, pedicel and flagellomere dark.

Thorax: Scutum dark, may appear shiny or metallic, pile dark in males and light in female; scutellum light to dark with darker lateral edges, pile dark with some light pile along lateral edges to light with some dark on posterior edge; wing cell br bare basally and above spurious vein, bm bare on anterior $1 / 2-3 / 4, r_{1}$ bare at base and some with cup bare posterior to vein CuP (Fig. 9C); haltere light; pro- and mesofemora dark on basal half, light on 
apical half, metafemur dark with light apical end, pro- and mesotibiae light, metatibia dark with light basal end, tarsi dark, pro- and mesotarsi with light ventral side.

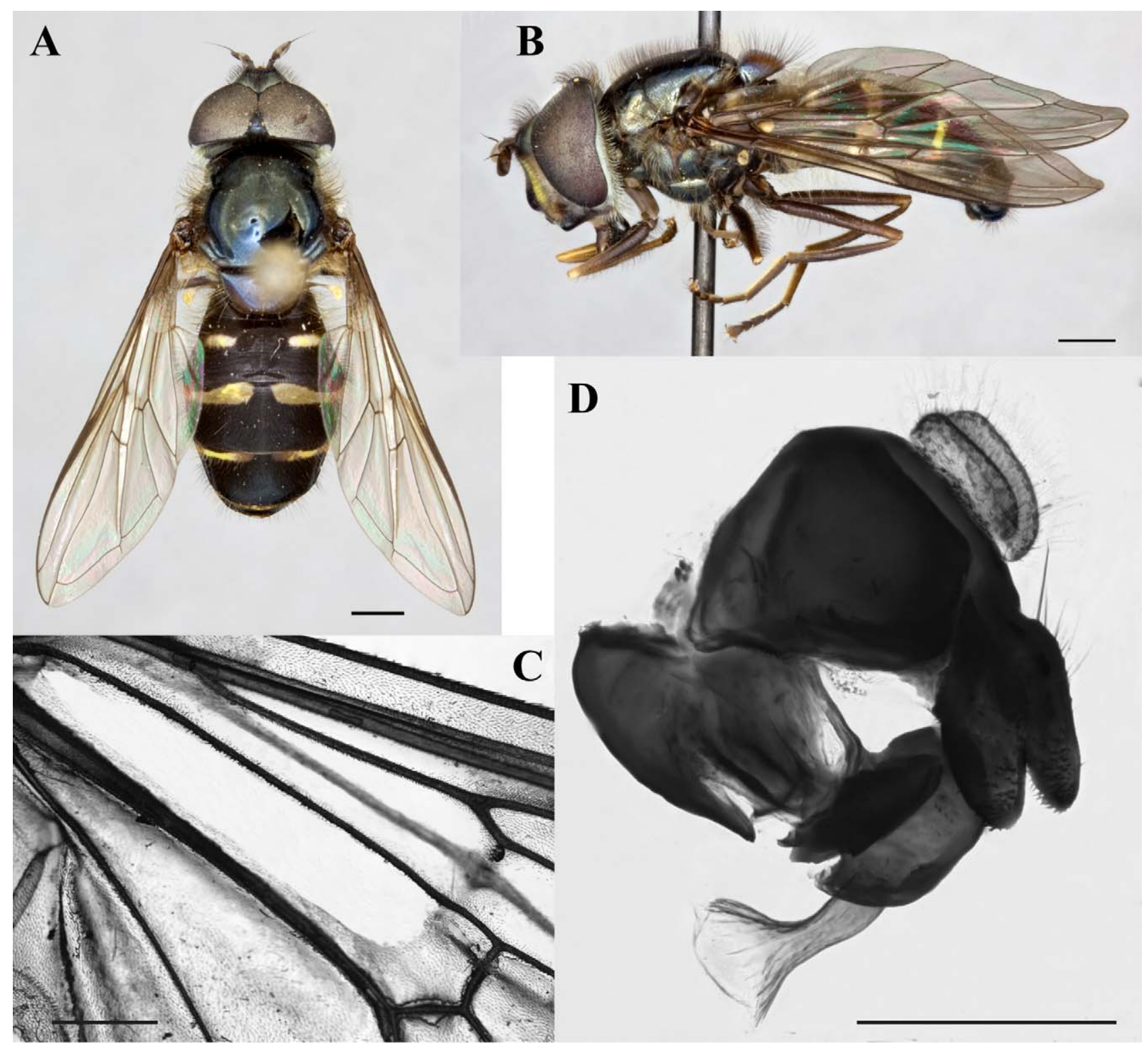

FIGURE 9. Dasysyrphus limatus: A: male (CNCD 13659) dorsal habitus; B: male (CNCD 13659) lateral habitus; C: wing base: (CNCD 13686); D: lateral view of male (JSS 20796) genitalia. Dorsal and lateral habitus scale bar $=1 \mathrm{~mm}$, genitalia and wing scale bar $=500 \mu \mathrm{m}$.

Abdomen: Maculae on tergite 2 small, slender and oval, $<1 / 4$ width of tergite, maculae on tergites $3 \& 4$ are transverse, slender and widen medially, narrowed toward margin, positioned anteriorly on the tergite, maculae cross abdominal margin (Fig. 9A); sternites light with thick, dark fasciae.

Male Genitalia: Surstylus more or less oval in shape in lateral view, flattened with long pile on posterior side and spines on anteroventral side; cercus oval with long pile over entire surface; gonostylus triangular-shaped in lateral view, wide at base and elongated posterodorsal with small pointed projection on posterodorsal edge, posterior edge flares laterally, making it difficult to see in lateral view; pile on dorsal surface; basiphallus is greatly enlarged dorsally, fully sclerotized all the way around with no pile or spines; distiphallus is short with no enlarged area basally, apical end flared out into horn, which is mostly sclerotized but membranous at apex with no setulae dorsally (Fig. 9D).

Intraspecific variation: Maculae on abdomen can be of varying thickness, however they are usually quite narrow. 
Etymology: The word limatus is Latin, meaning polished, refined.

Distribution: Canada (AB, BC, NT, NS, QC, YT), USA (AK, CO, MA, ME, NY, UT) (Fig. 20D)

Ecology: Collected on common cow parsnip (Heracleum maximum). Collected from "sand dunes" and "outlet marsh" habitats. Collected April to September, although much more frequently collected from June through August. Collected from elevations of 320m-3002m.

Discussion: The concept of limatus has been applied consistently since Hine erected the name in 1922.

Type Material: "Savonoski/ Naknek Lake/ Alaska/ July '19", "Jas. S. Hine/ Collector", red label "Allotype”, yellow label "PARALECTOTYPE/ Syrphus/ limatus/ Hine", barcode label "OSUC 0373263"; 今"; deposited in the Ohio State University Collection (OSU). (examined)

Material Examined:

Paralectotype: United States of America: Alaska: Savonoski. Naknek Lake, [58.497288, -155.266794], vii.1919, ${ }^{\circ}$, OSUC 319689, Jas. S. Hine (OSU); vii.1919, $\widehat{\jmath}$, CNCD 87874, J. S. Hine (CNC). Other Material Examined: Canada: Alberta: BANFF NATIONAL PARK: Sulphur Mountain, [51.149438, -115.583484], 2195m, 28.vii.1967, +, CNCD 13699, J.R. Vockeroth (CNC); Banff, [51.180275, -115.568433], 9.vi.1922, ðૈ, CNCD 13647, C.B.D. Garrett (CNC); Mile 14 Banff-Jasper Highway, [51.231247, -115.838509], 3.viii.1955, , CNCD 13686, R. Coyles (CNC); Snow Creek Pass, [51.60524, -115.808617], 2256m, 28.vii.1962, q, CNCD 13687, W.R.M. Mason (CNC). British Columbia: Vaseux L. Hills to E, [49.316685, -119.523082], 2.v.1983, §̂, JSS 20038, S.G. Cannings (UBCZ). CENTRAL Kootenay L.D.: Robson, [49.333015, -117.692871], 6.v.1958, ठૈ, RBCM ENT 99188122, 11.v.1966, Ô, Royal British Columbia M ENT 99188124, H.R. Foxlee (RBCM);

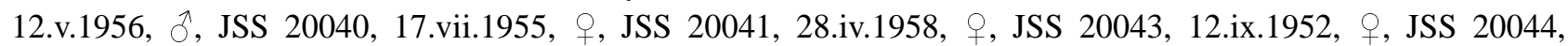

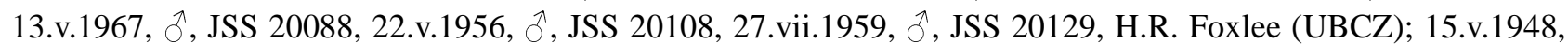
${ }^{3}$, CNCD 13656, 11.v.1948, 2 , CNCD 13657, 14473, H.R. Foxlee (CNC). Squamish, Diamond Head Trail, [49.811126, -123.07434], 975m, 9.viii.1953, +, CNCD 13683, G.J. Spencer (CNC). Mount Revelstoke NATIONAL PARK: Mt. Revelstoke, [50.98333333, -118.2], 1.viii.1952, ㅇ, CNCD 533, G.P. Holland (CNC); 13.viii.1952, 9 , CNCD 48545, G. J. Spencer (CNC); Mount Harry, [51.035979, -118.142509], 1890m, 20.vii.1952, +, CNCD 13682, G.J. Spencer (CNC). CASSIAR L.D.: Moosehorn Lake, [58.164009, -132.12694], 1372m, 1.viii.1960, + , CNCD 13678, W.W. Moss (CNC); 1372m, 30.vii.1960, + , CNCD 13679, R. Pilfrey (CNC). NORTHERN Rockies R.D.: Summit Lake, Mile 392 of Alaska Highway, [58.648201, -124.666912], 1280m, 21.vii.1959,, , CNCD 13680, 15.vii.1959,, , CNCD 13681, R.E. Leech (CNC). Liard R. hotsprings, [59.425991, -126.096398], 23.vii.1987, +, JSS 20046, S.G. Cannings (UBCZ). Atlin, [59.5775, -133.69236], .viii.,, , CNCD 13684, (CNC). Campbell Mtn., Pentiction, 880m, 13.v.1983, đ̂, JSS 20039, S.G. Cannings (UBCZ). Northwest Territories: Muskox Lake, [64.633135, -108.249285], 20.vii.1953, §̃, CNCD 13645, J.G. Chillcott (CNC). 21 miles east Tuktoyaktuk, [69.426844, -132.172475], 2-5.vii.1971, ô, CNCD 13646, 20-25.vi.1971, + , CNCD 13694, D.M. Wood (CNC). Nova Scotia: CAPE BRETON HighlandS NATIONAL PARK: Mackenzie Fire Tower, [46.773977, -60.818772], 8.vii.1983, §̂, CNCD 13665, D.M. Wood (CNC). Quebec: Cté Missisquoi summit Mt Pinacle, [45.018184, -72.855064], 700m, 20.vi.1991, ô, JSS 20795, D.M. Wood (CNC). BROME-MisSISQuOI: Knowlton, [45.216716, -72.514769], 12.vi.1928, + , CNCD 13651, W.J. Brown (CNC). Summit of Mt. Rigaud, [45.46638889, -74.32638889], 4.vi.1978, 40, CNCD 5809, 13659-13661, D.M. Wood (CNC). LA VALLEE-DURICHELIEU: Mont Saint-Hilaire, [45.552948, -73.155276], 17.vi.1965, ð, CNCD 13667, 27.vi.1965, 4ð, CNCD 13668-13671, J.W. Boyes (CNC). TemisCAminguE: Laniel, [47.045828, -79.268979], 10.vi.1931, ㅇ, CNCD 13688, H.S. Fleming (CNC). Sakami (LG3), [53.71666667, -76.06666667], 13-18.vii.1977, $2 \overbrace{}^{\Uparrow}$, CNCD 5808, 13658, D.M. Wood (CNC). Lac Duplanter, Lac Delorme, [54.883534, -69.78209], 7-12.vii.1977, $3 \hat{\jmath}$, CNCD 13662-13664, D.M. Wood (CNC). Kuujjuaq (Fort Chimo), [58.100076, -68.406179], 28.vii.1948, 2q, CNCD 13689, 13690, R.H. MacLeod (CNC). Yukon Territory: Carcross, [60.186691, -134.692703], 16-18.vi.1982, §, CNCD 13666, G. \& M. Wood (CNC). Whitehorse, [60.733402, -135.082092], 22.vii.1959, q, CNCD 13698, R. Madge (CNC). Haines Jct., [60.752472, -137.510006], 29.vi.1974,, , JSS 20181, G.G.E. Scudder (UBCZ). Otter Lake, [62.486817, -130.4166667], 1219m, 28.vii.1960, +, CNCD 13650, 29.vii.1960, ${ }^{\circ}$, CNCD 13696, E.W. Rockburne (CNC). Sheldon Lake, [62.616763, -131.266603], 1067m, 3.vii.1960, Ö, CNCD 13654, E.W. Rockburne (CNC); 3.vii.1960, क, CNCD 13915, 7.vii.1960, ô, CNCD 13655, क, CNCD 13695, J.E.H. Martin (CNC). La Force Lake, [62.683333, -132.333333], 1006m, 27.vi.1960, §, CNCD 14010, J.E.H. Martin (CNC). Borth Fork Pass, [64.51666667, -138.2166667], 1067m, 27.vii.1982, +, JSS 20045, S.G. Cannings, L. Vasington, R.A. Moore (UBCZ). North Fork Crossing, Mile 43 Peel Pit Road, [64.565983, -138.250648], 1067m, 6.vii.1962, 


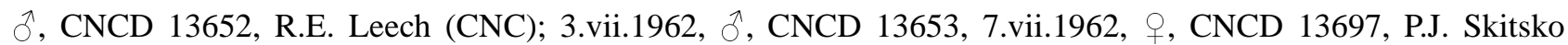
(CNC). DEMPSTER HighWAY: km 82, [64.581259, -138.261721], 1300m, 20.vii.1981 21.vii.1981, +, CNCD 13685, Lafontaine and G. \& M. Wood (CNC); Mile 87, [65.054721, -138.128324], 27-30.vi.1973, Oૈ, CNCD 13649, 5-7.vii.1973, o, CNCD 13691, 16-17.vii.1973, q, CNCD 13693, 4-8.viii.1973, + , CNCD 13692, G. \& D.M. Wood (CNC); km 416, [66.644581, -136.324471], 750m, 22-28.vi.1980, 3 ${ }^{\lambda}$, CNCD 13675-13677, Wood \& Lafontaine (CNC); km 465, [67.046392, -136.209668], 800m, 5-7.vii.1980, 今, CNCD 13674, Wood \& Lafontaine (CNC). Richardson Mts, [66.04166667, -135.5333333], 1219m, 6.vii.1982, ð, CNCD 5810, 762m, 7.vii.1982, 3 , CNCD 532, CNCD 13672, 13673, D.M. Wood (CNC). British Mts., [69.21666667, -140.0833333], 320m, 21.vi.1984 26.vi.1984,, , JSS 20774, G. \& M. Wood \& D. Lafontaine (CNC). United States of America: Alaska: Katmai, [58.033889, -154.876944], viii.1917, + , CNCD 112302, J. S. Hine (CNC). BRISTOL BAY Co.: Savonoski, Naknek River, [58.716814, -156.865366], vii.1919, đ̃, JSS 19479, , JSS 19478, J.S. Hine (CNC). MATANUSKASusitna Co.: Matanuska, [61.541945, -149.229674], vii.1944, 3 , JSS 19483, 19484, 19489, J. Chamberlin (CNC); vii.1944, +, OSAC 133385, J. Chamberlin (OSAC). DenAli Co.: Healy, [63.845424, -149.013681], 26.vi.1921, +, JSS 19485, 27.vi.1921, J, JSS 19524, J.M. Aldrich (CNC). Unalakleet, [63.86666667, 160.7833333], 8.viii.1961, + , CNCD 112193, 9.viii.1961, +, CNCD 112194, 15.viii.1961, + , CNCD 26574, B.S. Heming (CNC). Umiat, [69.36666667, -152.1333333], 6.vii.1959, †, CNCD 26579, J.E.H. Martin (CNC). Colorado: LAKE COUNTY: Tennessee Pass, [39.357246, -106.313889], 24.vii.1917, , JSS 19490, J.M. Aldrich (CNC). Loveland Pass, Western Slope, [39.65, -105.8666667], 3002m, 28.vii.1961, 2ð, CNCD 26385, 26386, J.G. Chillcott (CNC). CLEAR CREeK Co.: Doolittle Ranch, Mt. Evans, [39.675739, -105.601348], 2987m, 23.vii.1961,

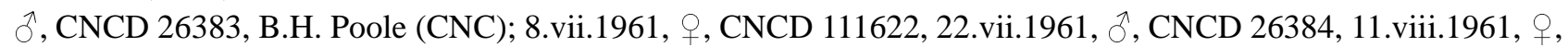
CNCD 112192, W. R. M. Mason (CNC); 23.vii.1961, , CNCD 35315, J.G. Chillcott (CNC). Chambers Lake,

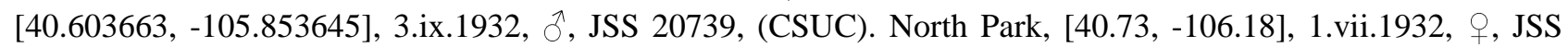
20733, (CSUC). Glendevey, [40.8078, -105.935501], 7.vii.1931, + , JSS 20741, C.R. Jones (CSUC). Maine: PISCATAQuis Co.: Mount Katahdin, [45.904968, -68.921017], 5.vii.1958, ð̊, JSS 19481, (CNC). Massachusetts: NORFOLK CO.: Wellesley Hills, [42.308427, -71.278693], 1963, , JSS 19482, D. Meissner (CNC). HAMPSHIRE Co.: Amherst, [42.34038, -72.496818], 15.v.1963, ㅇ, JSS 19486, S.T. William (CNC); 8.v.1965, ㅇ, JSS 19487, Mansfield (CNC); 8.v.1965, đ̂, JSS 19488, B. Scott (CNC); 6.v.1973, §, USNM ENT 258065, A. Lavallee (USNM). New York: EsSEX Co.: Mount MacIntyre Summit, [44.132434, -74.007381], 26.vi.1941, §, CNCD 26387, H. Dietrich (CNC); Mount Hurricane, [44.233601, -73.708728], vi.1939, Õ, JSS 19480, R.C. Shannon (CNC). Utah: CACHE Co.: Cowley Canyon, [41.772669, -111.60407], 10-17.viii.1989, JSS 25132, W.J. Hanson (EMUS); Logan Cyn., Turner Campground, [41.85, -111.5666667], 2.vii.2003 6.vii.2003, + , JSS 24607, W.J. Hanson \& Brammer (EMUS); Tony Grove Creek, [41.886599, -111.564102], 29.vi.-8.vii.1994, Ô, JSS 24610, 815.vii.1994, JSS 24608, 25121-25124, 25127, 15-26.vii.1994, JSS 25128, 4-12.viii.1994, JSS 25131, 1219.viii.1994, JSS 24609, 25125, 25126, 25129, 25130, W.J. Hanson (EMUS); West Hodges Canyon, [41.910305, 111.42277], 8.viii.1978 11.viii.1978, JSS 25133, Hanson, Knowlton (EMUS).

\section{Dasysyrphus lotus (Williston)}

Figures: 10A-D, 21A

Synonyms and References:

Syrphus lotus Williston 1887: 75 (original description)

Metasyrphus lotus

Fluke 1933: 108 (key, redescription and transfer to Dasysyrphus)

Dasysyrphus lotus

Stone et al. 1965: 564 (catalogue and transfer to Dasysyrphus)

Vockeroth 1992: 67 (key and redescription)

Diagnosis: Abdominal maculae do not cross abdominal margin; maculae on tergites $3 \& 4$ oblique and usually meet in the middle; face and gena continuously light (Figs 10A \& B).

Redescription:

Body Length: 9.4-11.7mm; Wing Length: $8.7-11.4 \mathrm{~mm}$

Head: Frons dark with light pollenose fascia (in males it runs along ventral edge of where eyes meet, in 
females it is complete and $>1 / 2$ the length between the antennae and ocelli) and dark pile; face light with dark vitta $1 / 4-1 / 3$ the width of the face and does not reach the antennal socket, face with light pile lateral to the eye, sometimes dark pile along fascia or dorsally, near frons; gena light (Fig. 10B) with light pile; occiput dark, covered in dense, light pollen, pile light, some with some dark; scape, pedicel and flagellomere dark.

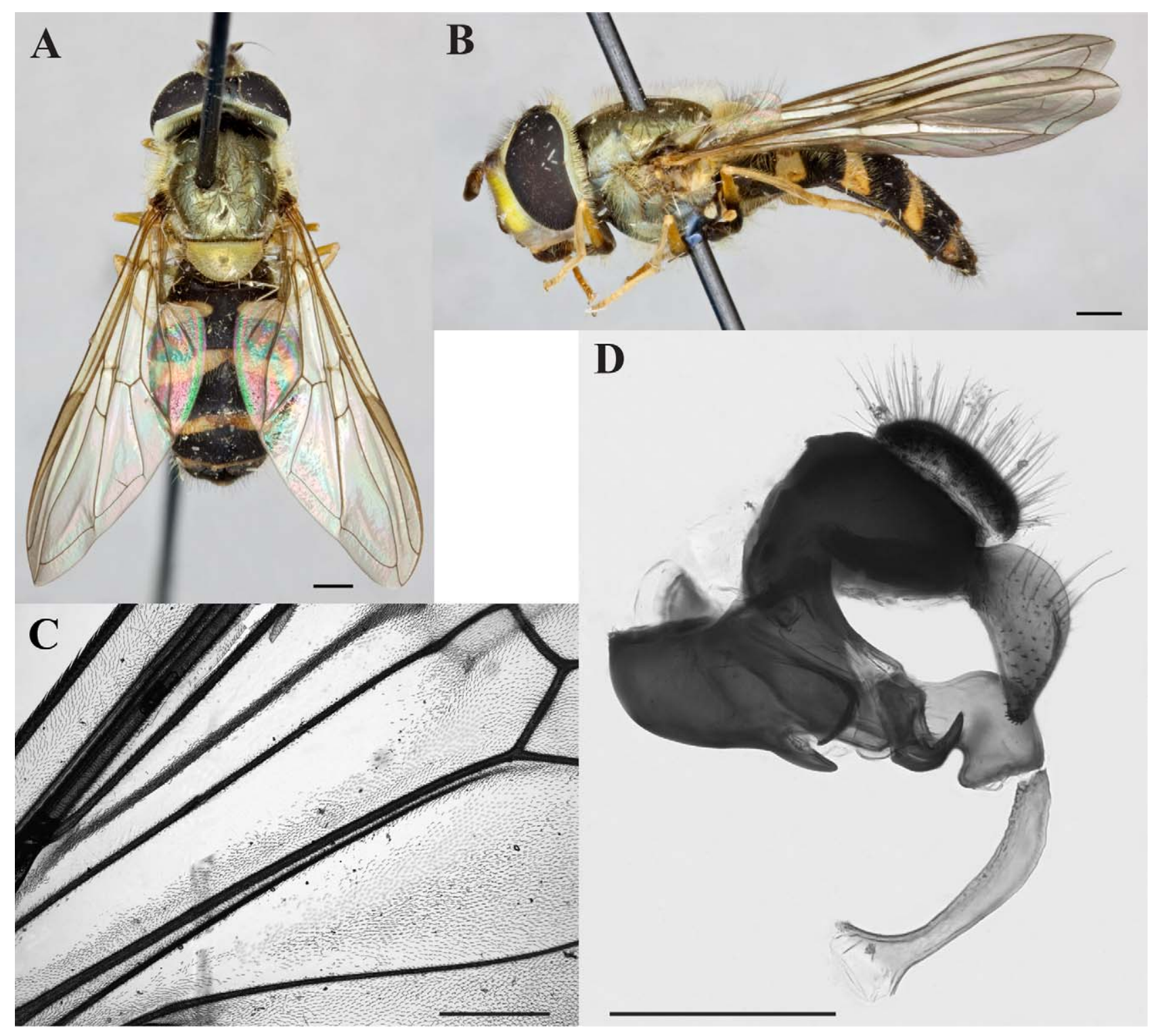

FIGURE 10. Dasysyrphus lotus: A: female (CNCD 26389) dorsal habitus; B: female (CNCD 26389) lateral habitus; C: wing base (CNCD 26397); D: lateral view of male (JSS 18303) genitalia. Dorsal and lateral habitus scale bar $=1 \mathrm{~mm}$, genitalia and wing scale bar $=500 \mu \mathrm{m}$.

Thorax: Scutum dark, may appear shiny or metallic, pile light; scutellum light with light pile along anterior edge, dark posteriorly; wing cell $\mathrm{c}$ and $\mathrm{r}_{1}$ bare at base, br bare above spurious vein and small to large areas below, bm bare on most of anterior half, and cup bare under CuP (Fig. 10C); haltere light; pro- and mesofemora $1 / 3-1 / 2$ dark basally $1 / 2-^{2} / 3$ light apically, metafemur $2 / 3-3 / 4$ dark basally, $1 / 4-1 / 3$ light apically, tibiae light, tarsi light, metatarsi with dark anterior side.

Abdomen: Maculae on tergite 2 large and triangular (lateral edge flattened and medial edge with rounded point), $1 / 3-<1 / 2$ width of tergite, maculae on tergites $3 \& 4$ are oblique and fairly straight, usually meeting medially, fairly uniform in thickness, narrowing toward medial edge slightly, maculae do not reach abdominal margin (Figs $10 \mathrm{~A} \& \mathrm{~B}$ ); sternites light with dark fasciae, anterior edge of fascia on sternite two usually angled forming a point in the centre.

Male Genitalia: Surstylus more or less triangular in shape in lateral view, with posterodorsal edge rounded, 
long pile on posterolateral surface, spines on anteroventral edge; cercus oval with long pile over entire surface; gonostylus hook-shaped with few pile on dorsal surface; basiphallus elongate, basally bent at about a 90 degree angle towards dorsum, apical end curved ventrally and fully sclerotized all the way around without pile or spines; distiphallus elongate, apical end flared out into small horn, which is mostly sclerotized but membranous at apex with minute setulae dorsally, basally curved towards dorsum and not enlarged (Fig. 10D).

Intraspecific variation: Abdominal maculae on tergites $3 \& 4$ usually meet medially, but sometimes they are completely separated from each other.

Etymology: The word lotus is Latin, meaning washed.

Distribution: Southwestern USA (AZ, CA) and Mexico (Fig. 21A).

Ecology: Collected from March to November at elevations from 1524-2743m.

Discussion: Williston (1887) discusses two different specimens of D. lotus in his species description. The first, the type, and another that he speculates is "allied" with the first. This second specimen is reported to have several differences, mainly the shape of the abdominal maculae and gena colour. Williston (1887) describes this second specimen as having a "black stripe on the cheeks" and he describes the abdominal maculae as being "more oblique, and strongly concave in front" and "more convex behind". In 1895 Snow describes this lotus variation as D. creper. Fluke (1933) states that most published records of lotus probably refer to creper and that most of the specimens identified as lotus agree with Williston's (1887) variation (the female from New Mexico). Fluke postulates that the specimen might be teneral due to the light head, but then goes on to say that it does not explain the differently shaped maculae. Curran's (1925) redescription of lotus also refers to creper. It is clear from the description of the abdominal maculae and the figure that he was not looking at Williston's (1887) lotus.

Dasysyrphus lotus COI data has a high mean intraspecific variation of 3.09\% (Table 2). In the NJ tree (Fig. 4), the two Nearctic specimens cluster closely together (1.34\% different), while the Neotropical specimen is 3.29 $4.38 \%$ different from the others. This is highly suggestive that lotus is a complex as currently defined. With an extremely similar habitus among these three specimens as well as the 21 specimens where it was not possible to extract DNA, it can be concluded that lotus s.l. occurs from the southwestern Nearctic through to the Neotropical region, but that it likely includes at least two species. Further investigation needs to be conducted to help discern whether the Neotropical specimens are indeed a new species.

Type Material: “Arizona,/ C.U. Lot 35", “Acc. 19,702/ Williston”, "Syrphus/ lotus/ Will.”, red label "Type/ No. 129/ U.S.N.M.”, "Jeff Skevington/ Specimen \#/ 23780”; o ; deposited in the United States National Museum of Natural History, Washington, D.C (USNM). (examined)

Material Examined:

Mexico: 10 Miles West of El Salto, [23.727593, -105.49364], 2743m, 10.vii.1964, 2 त, CNCD 26391, 26392, J.F. McAlpine (CNC). Amecameca, [19.119148, -98.764597], ix.1900, Оૈ, USNM ENT 35111, O.W. Barrett (CNC). Atlacomulco, 8.x.1954, Oै, JSS 21093, R. Dreisbach (MSUC). United States of America: Arizona: Cochise Co.: Carr Canyon, [31.440158, -110.289641], 1524m, 29.x.1967, ô, CNCD 26388, 2 , CNCD 26393, 26394, R.F. Sternitzky (CNC); Ramsey Canyon, [31.447697, -110.307712], 10.iv.1967, +, CNCD 26397, 12.vi.1967, 2甲, CNCD 26395, 26396, 28.vii.1967, CNCD 60065, 1-15.ix.1967, §, CNCD 26389, 1-8.x.1967, q, CNCD 26398, 15.xi.1967, đૈ, CNCD 106795, R.F. Sternitzky (CNC); 23.ix.1994, ðૈ, JSS 18303, J.E. O'Hara (CNC); Miller Can., 3.v.1948, ô, JSS 23760, A.L. Melander (USNM). SANTA CRUZ Co.: Canelo, [31.542591, 110.514478], 1372m, 17.iii.1967, Ô, CNCD 26390, R.F. Sternitzky (CNC). PIMA Co.: Mount Lemmon, San Catalina Mountains, [32.443131, -110.788429], 2377m, 29.vii.1917, $\odot$, CNCD 26399, (CNC). California: ELDORADO CO., Blodgett Experimental Forest, [38.87882, -120.659071], 7.vi.1975, Ô, JSS 18302, D. Voeatlia $(\mathrm{CNC})$.

\section{Dasysyrphus nigricornis (Verrall)}

Figures: 11A-E, 18B, 21A

Synonyms and References:

Scaeva obscura Zetterstedt 1838: 601 (original description, name preoccupied) Bicik \& Laska 1996 (lectotype designation and discussion)

Syrphus nigricornis Verrall 1873, 251 (new name given, short description and transfer to Syrphus) Verrall 1901: 353 (discussion) 
Becker 1921: 44 (redescription)

Syrphus obscuratus Ringdahl 1928: 19 (original description)

Syrphus nigricornis var. obscuraticeps Frey 1950: 10 (original description)

Dasysyrphus nigricornis Verrall:

Peck 1974: 128 (key and transfer to Dasysyrphus)

Peck 1988: 15 (catalogue)

Barkalov 2007: 283 (key and redescription)

Speight 2011: 70 (discussion)

Diagnosis: Abdominal maculae of tergites $3 \& 4$ oblique, fairly uniform in thickness with slight constriction in the middle and do not cross abdominal margin (Figs 11 A-C). Maculae on tergite 2 of male small ( $<1 / 4$ width of tergite), triangular to oval and close to lateral edges (Fig. 11A), in female are larger $(1 / 4-1 / 3$ width of tergite) and narrowly oval (Fig. 11B); usually darker in appearance due to reduced maculae. Wing densely microtrichose (Fig. 11D). Gonostylus boot-shaped with projection on posterodorsal surface that projects posterodorsally (Fig. 11D). Similar in appearance to D. pauxillus (Fig. 14A), pacificus (Fig. 13A) and laticaudus (Fig. 8A).

Redescription:

Body Length: 5.5-7.7mm; Wing Length: 4.5-7.7mm

Head: Frons dark with light pollenose fascia (in males it runs along ventral edge of where eyes meet, in females it is complete and $1 / 3-1 / 2$ the length between the antennae and ocelli (Fig. 18B)) and dark pile; face light with dark vitta $1 / 4-1 / 2$ the width of the face, usually not reaching antennal socket, face with dark pile lateral to the eye; gena dark, typically dark pile, but sometimes light; occiput dark, covered in light pollen, pile light; scape and pedicel dark, flagellomere dark.

Thorax: Scutum dark, may appear shiny or metallic, pile varies between all light and dark anteriorly, light posteriorly; scutellum light to dark with darker lateral edges, light pile sometimes with light and dark pile; wings entirely microtrichose (Fig. 11D); haltere light; pro- and mesofemora dark to dark $1 / 2$ basally, $1 / 2$ light apically, metafemur dark, pro- and mesotibiae all dark to all light, meta tibiae all dark to light $1 / 3$ basally, dark $2 / 3$ apically, tarsi dark.

Abdomen: Maculae on tergite 2 small ( $<1 / 4$ width of tergite), triangular to oval and close to lateral edges in males (Fig. 11A), larger (1/4-1/3 width of tergite) and narrowly oval in females (Fig. 11B), maculae on tergites $3 \& 4$ are oblique, fairly uniform in width with slight constriction in the middle, maculae do not reach abdominal margin (Figs 11A-C); sternites light with dark fasciae varying in thickness.

Male Genitalia: Surstylus more or less triangular in shape in lateral view, flattened posteriorly, long pile on dorsal, laterodorsal and posterodorsal sides, row of spines on posteromedial edge; cercus oval with long pile over entire surface; gonostylus boot-shaped with projection on posterodorsal surface that projects posterodorsally, pile on dorsal surface; basiphallus elongate, basally bent at 135 degree angle towards anterodorsum, apical end curved ventrally and is partly membranous dorsally, with spines on posterodorsal side; distiphallus elongate, apical end flared out into horn, which is mostly sclerotized but membranous at apex with minute setulae dorsally, basally bent towards dorsum and enlarged ventrally at bend (Fig. 11D).

Intraspecific variation: Maculae on tergite two can vary in width. In males maculae are typically $<1 / 4$ the width of the tergite, but in rare occasions may be up to $1 / 3$ of the width. In females hey are typically $1 / 4-1 / 3$ the width. Maculae on tergite $3 \& 4$ in the male look similar to those of pauxillus, pacificus and laticaudus, however in the female the maculae tend to be slightly thinner than similar species and sometimes are more narrow on the medial edge.

Etymology: From the Latin niger, meaning black, dark, dusky, and cornus, meaning horn (possibly referring to antennae).

Distribution: Northern Canada (MB, NL, NT, QC, YT), Northern USA (AK) and Greenland (Fig. 21A). Palaearctic (likely throughout far north but distribution needs to be verified).

Ecology: Has been collected from late May-July, from elevations of 762-1250m.

Discussion: Dasysyrphus nigricornis is recognized from the Nearctic for the first time. Long buried within pauxillus in this region, specimens from northern Canada and the United States are morphologically and genetically different from pauxillus and the two other species also split off from it here, laticaudus and pacificus. Male genitalia of these Nearctic specimens match the genitalia of the nigricornis paralectotype figured by Bicik \& Laska (1996, Fig. A). Part of the reason that this species has not been recognized in this region before is that much 
confusion has existed over the use of the name in the Palaearctic. When Verrall provided a new name for obscura in 1873, because the name was preoccupied, he used specimens from Scotland for his description. However, obscura was described by Zetterstedt from Scandinavia and is not known to occur in the United Kingdom (Bicik \& Laska 1996; Speight 2011). The material used by Verrall in his redescription is apparently actually pinastri, leading to the obvious confusion. In 1996, Bicik \& Laska examined the type series of obscura to help straighten out the nomenclature. Upon their examination of the type series they found three different species, three specimens of nigricornis s.s., two of pauxillus s.l. and one of pinastri. They selected a lectotype to stabilize the name, as well as provided figures of genitalia and characters to differentiate nigricornis from pauxillus s.l. and pinastri.

Despite being morphologically distinct from $D$. occidualis, $D$. nigricornis cannot be separated from occidualis by COI DNA.

Type Material: "S. obscura Juckasj." (Zetterstedt label), "S. obscuraticeps Frey" (Heese label, 1969), number: "185", O, deposited in the Museum of Zoology, Lund University (MZLU), Lund, Sweden (Bicik \& Laska 1996). (not examined)

Material Examined:

Canada: Manitoba: CHURCHILL AREA: Warkworth Creek, [58.507672, -93.997769], 10.vi.1952, đ, CNCD 13766, C.D. Bird (CNC); Burn site N[orth] of Twin lakes, [58.61861111, -93.82888889], 29.vi.2007, 3 ${ }^{\lambda}$, CNCD 9204-9206, J. Skevington (CNC); Bluff D at Bird Cove, [58.76166667, -93.89833333], 30.vi.2007, CNCD 9274, J. Skevington (CNC). Newfoundland and Labrador: Pinware River Provincial Park, Division No. 9, [51.634267, -56.708114], 29.vi.1983, O, CNCD 13902, A. Borkent (CNC). Cartwright, [53.694772, -57.010406], 29.vi.1955, + , CNCD 13903, E.E. Sterns (CNC). Northwest Territories: Resdelta, Great Slave Lake, [66.051734, 120.780449], 22.vi.1944, , CNCD 13777, J.R. Vockeroth (CNC). Km 491 Dempster Highway, [67.182795, 135.791046], 26.vi.1982, §, CNCD 13772, G. \& M. Wood (CNC). Aklavik, [68.219638, -135.010707], 30.vi.1956, $q$, CNCD 13776, E.F. Cashman (CNC). Reindeer Depot, Mackenzie Delta, [68.668974, -134.071574],

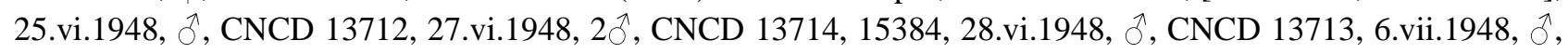
CNCD 13715, J.R. Vockeroth (CNC). Granet Lake, Franklin, [68.701471, -125.58813], 20.vii.1969, ㅇ, CNCD 13778, G.E. Shewell (CNC). 21 miles east Tuktoyaktuk, [69.426844, -132.172475], 20-25.vi.1971, 4^, CNCD

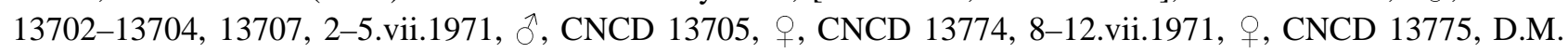
Wood (CNC); 21.vi.1971, §, CNCD 13706, W.R.M. Mason (CNC). Tuktoyaktuk, [69.438369, -133.01637],

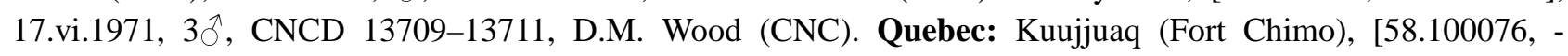
68.406179], 23.vii.1948, + , CNCD 13879, R.H. MacLeod (CNC). Yukon Territory: Swim Lakes, [62.210135, 132.809978], 975m, 11.vi.1960, , CNCD 13568, 15.vi.1960, + , CNCD 13733, 25.vi.1960, 2 9 , CNCD 13734, 13735, J.E.H. Martin (CNC). Sheldon Lake, [62.616763, -131.266603], 1067m, 7.vii.1960, 2 q, CNCD 13737, 13738, E.W. Rockburne (CNC). La Force Lake, [62.683333, -132.333333], 1006m, 26.vi.1960, ㅇ, CNCD 13726,7.vii.1960, +, CNCD 13722, 9.vii.1960, , CNCD 13723, 10.vii.1960, 2 9, CNCD 13724, 13725, J.E.H. Martin (CNC); 25.vi.1960, +, CNCD 13732, 7.vii.1960, +, CNCD 13727, 11.vii.1960, +, CNCD 13729, 13.vii.1960, 2甲, CNCD 13730, E.W. Rockburne (CNC). Hunter Creek, Dawson, [63.779, -138.61], 914m, 3.vii.1949, đ, CNCD 13701, + , CNCD 13740, P.F. Bruggemann (CNC). Dawson, [64.050017, -139.41052], 16.vi.1949, + , CNCD 13741, W.W. Judd (CNC). North Fork Pass, Ogilvie Mountains, [64.565983, -138.250648], 1250m, 12.vi.1962, Ô, CNCD 13700, R.E. Leech (CNC). North Fork Crossing, Mile 43 Peel Pit Road, [64.565983, -138.250648], 1067m, 4.vii.1962, +, CNCD 13736, P.J. Skitsko (CNC). DEMPSTER HighwAY: Mile 51, [64.605992, -138.33789], 17-21.vi.1973, 今ึ, CNCD 13708, ㅇ, CNCD 13739, G. \&D.M. Wood (CNC); km 465, [67.046392, -136.209668], 25-26.vi.1982, 2§, CNCD 5811, 13720, $\overbrace{}^{\lambda}$ and + (pinned together), CNCD 13719, G. \& M. Wood (CNC); Wright Pass, [67.083297, -136.162751], 9.vii.1985, ㅇ, JSS 20169, S.G. Cannings (UBCZ). Richardson Mountains, [68.163651, -136.988868], 762m, 12.vii.1982, ô \& $\odot$, CNCD 13721, M. Wood (CNC). Greenland: Sondrestrom Air Base; Near Sugar Loaf Mountain, [67.010556, -50.709167], 11.vii.1963, ô, JSS 23779, T.J. Curtin (USNM). United States of America: Alaska: MatanusKa-Susitna Co.: Matanuska,

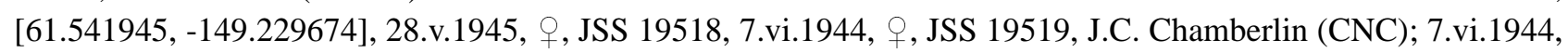
2へ, JSS 19520, 19521, J.C. Chamberlin (USNM). Mount Fairplay, Mile 32 Taylor Highway, [63.679038, 142.262944], 1097m, 10.vii.1962, ㅇ, CNCD 26443, P.J. Skitsko (CNC). Nome Area, Mile 17 of Kougarok Road, [64.70611111, -165.2972222], 26.vi.2005 28.vi.2005, क, CNCD 30896, J.\&R. Skevington (CNC). Umiat, [69.36666667, -152.1333333], 24.vi.1947, §, JSS 19522, K.L. Knight (USNM). 


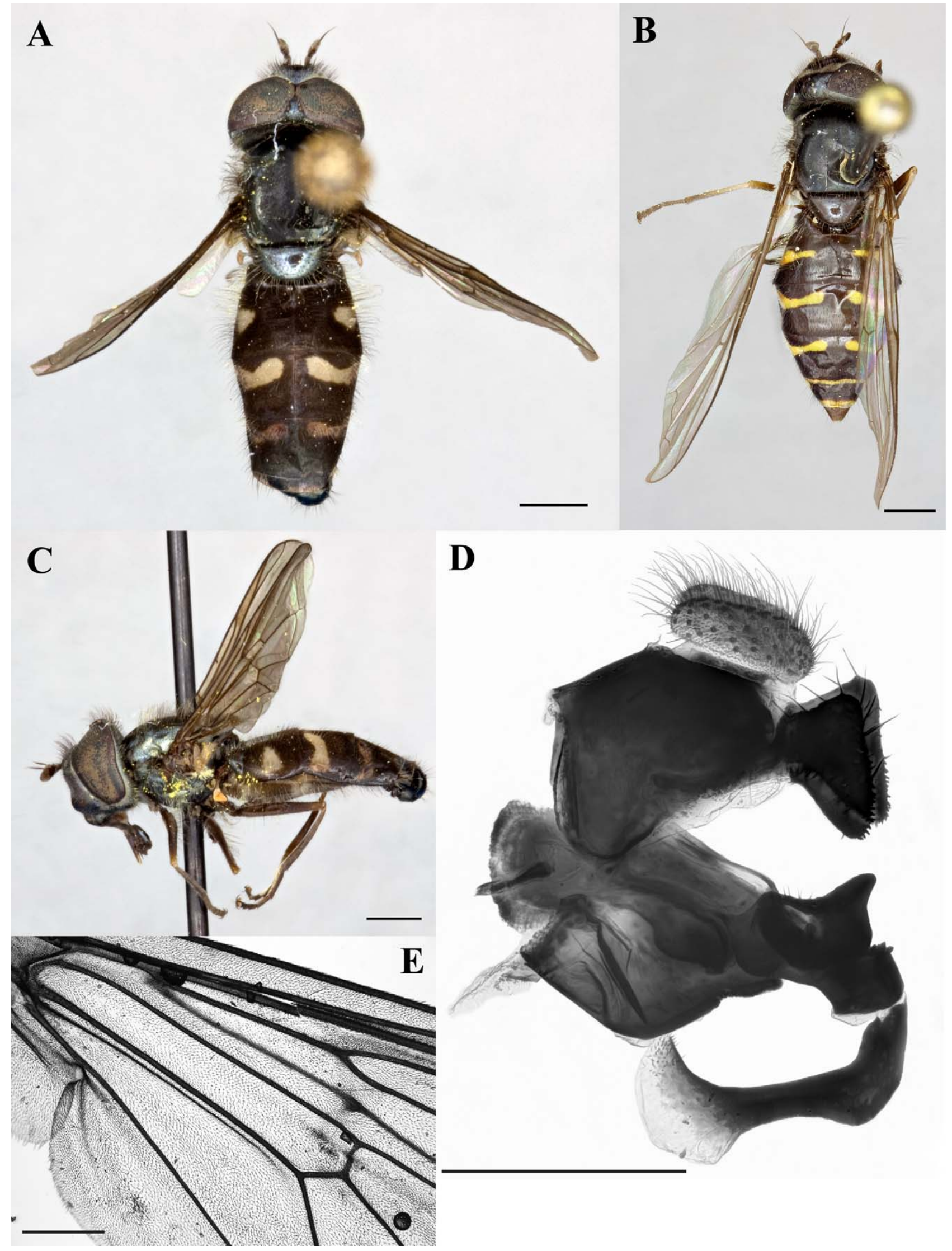

FIGURE 11. Dasysyrphus nigricornis: A: male (CNCD 13711) dorsal habitus; B: female (CNCD 13568) dorsal habitus; C: male (CNCD 13711) lateral habitus; D: lateral view of male (CNCD 9206) genitalia; E: wing base (CNCD 13725). Dorsal and lateral habitus scale bar $=1 \mathrm{~mm}$, genitalia and wing scale bar $=500 \mu \mathrm{m}$. 


\section{Dasysyrphus occidualis Locke \& Skevington sp. nov.}

Figures: 12A-E, 21B

Synonyms and References:

Syrphus amalopis Osten Sacken:

Williston 1887: 69 (in part; description)

Metasyrphus amalopis:

Fluke 1933: 110 (in part; key and redescription)

Dasysyrphus amalopis:

Stone et al. 1965: 563 (in part; catalogue)

Vockeroth 1992: 63 (in part; key and redescription)

Diagnosis: Abdominal maculae do not meet abdominal margin; maculae on tergites $3 \& 4$ are constricted medially and are either divided or not (Figs 12A-C). Wings cell br usually with a small bare area above base of spurious vein (Fig. 12E). Surstylus with a prominent posterolateral edge (Fig. 12D). Similar to D. amalopis, but D. amalopis has maculae on tergites $3 \& 4$ usually undivided (Fig. 5A), cell br densely microtrichose and does not have a prominent posterolateral edge on the surstylus (Fig. 5C). Male genitalia should be used to reliably differentiate between these two species. There is a range of overlap in southern Yukon where it may not be possible to distinguish between females of these two species due to variations in the aforementioned characters.

Description:

Body Length: 8.0-11 mm; Wing Length: 7.2-10.7mm

Head: Frons dark with light pollenose fascia (in males it runs along ventral edge of where eyes meet, in females it is continuous, $1 / 3-1 / 2$ the length between the antennae and ocelli) with dark pile; face light with dark vitta $<1 / 4-1 / 3$ the width of the face, usually not reaching antennal socket, if it does then narrowly so, face with dark pile; gena dark with dark pile ventral to the eye and light pile elsewhere; occiput dark, covered in light pollen, pile light; scape, pedicel and flagellomere dark.

Thorax: Scutum dark, may appear shiny or metallic, pile light anteriorly and dark posteriorly (amount varies); scutellum light to dark with darker lateral edges, some light pile along anterior edge and dark pile elsewhere; wing densely microtrichose, cell br usually with small bare areas at above base of spurious vein, $r_{1}$ sometimes bare at base and cup sometimes bare in areas along vein CuP (Fig. 12E); haltere light; pro- and mesofemora 1/2-3/4 dark basially, $1 / 4-1 / 2$ light apically, metafemur $3 / 4$ dark basially, $1 / 4$ light apically, tibiae variable from all light to slightly darkened apically to $3 / 4$ dark apically, tarsi light with dark anterior side to all dark.

Abdomen: Maculae on tergite 2 large, $1 / 3-<1 / 2$ the width of tergite 2 , and oval with constriction medially (sometimes just slight constriction), maculae on tergites $3 \& 4$ are oblique and constricted medially, usually completely dividing maculae into four spots, if not completely divided then maculae on tergite 4 usually more constricted that on tergite three and almost divided, maculae do not reach abdominal margin (Figs 12A-C); sternite 2 is light with a dark triangular to straight macula connecting with the lateral edges of the sternite, sternites $3 \& 4$ are light with dark fasciae of varying thickness.

Male Genitalia: Surstylus more or less triangular in shape in lateral view, flattened posteriorly with prominent posterolateral edge, long pile on dorsal, laterodorsal and posterodorsal sides, row of spines on posteromedial edge; cercus oval with long pile over entire surface; gonostylus boot-shaped with pointed projection on posterodorsal surface that projects dorsally, pile on dorsal surface; basiphallus elongate, basally bent at about a 135 degree angle towards the anterodorsum, apical end curved ventrally with a widened apex and is partly membranous dorsally, with spines on posterodorsal side, apex; distiphallus elongate, apical end flared out into horn, which is mostly sclerotized but membranous at apex with minute setulae dorsally, basally bent towards dorsum and enlarged ventrally at bend (Fig. 12D).

Intraspecific variation: The maculae on tergites $3 \& 4$ are often divided (Fig. 12B). If not completely divided then maculae on tergite 4 usually more constricted that on tergite three and almost divided. Can have maculae on tergites $3 \& 4$ entire, but this less common (Fig. 12A). Wing densely microtrichose, except for cell br, which is usually bare above base of spurious vein, sometimes only in very tiny areas with one or two microtrichia missing, $r_{1}$ sometimes bare of microtrichia at base and cup sometimes bare in areas along vein CuP (Fig 12E).

Etymology: From the Latin occidualis, meaning western.

Distribution: Western Canada (AB, BC, YT) and western USA (AK, CO, WA, WY) (Fig. 21B). 


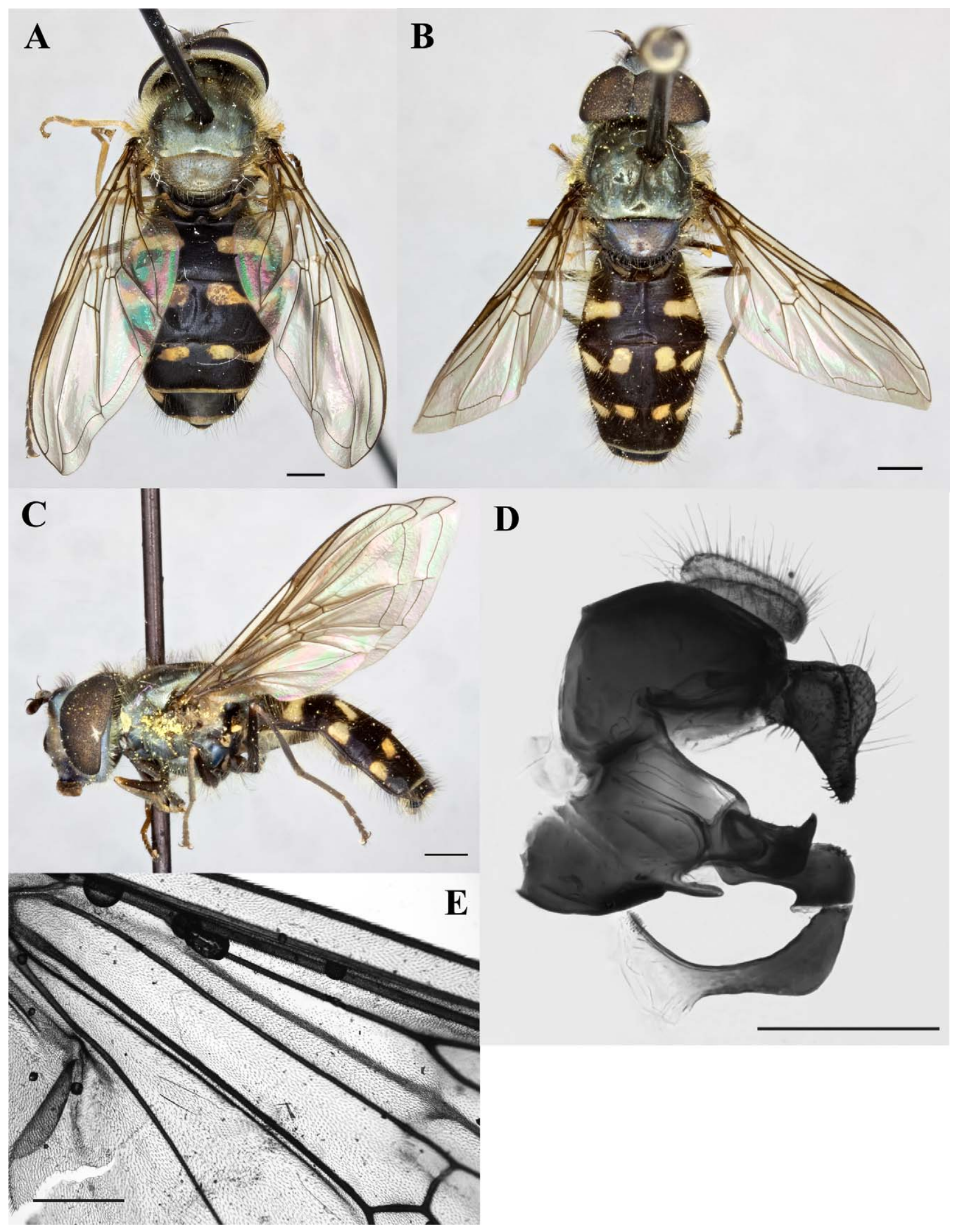

FIGURE 12. Dasysyrphus occidualis: A: female (CNCD 60043) dorsal habitus; B: male (OSU 0000133386) dorsal habitus; C: male (OSU 0000133386) lateral habitus; D: lateral view of male (JSS 20804) genitalia; E: wing base (CNCD 60046). Dorsal and lateral habitus scale $b a r=1 \mathrm{~mm}$, genitalia and wing scale bar $=500 \mu \mathrm{m}$. 
Ecology: Collected from May-August, but more frequently collected in July. Collected at elevations of 613$3658 \mathrm{~m}$. Habitats listed on labels include "outlet marsh", "sedge fen" and "subalpine".

Discussion: Until now, D. occidualis has been hidden within D. amalopis. With an absence of distinguishing external morphological characters, additional data were necessary to illuminate cryptic species such as this. In this study, COI DNA first highlighted the existence of two distinctly different genetic clusters within amalopis. Upon further inspection of the specimens, the male genitalia showed a prominent posterolateral edge on the surstylus (Fig. 12D), which amalopis does not have (Fig. 5C). When their geographic ranges were studied it was found that specimens of occidualis were only located in western Canada and the US (from Alaska to Colorado), while amalopis was found only in northern Canada. There is an overlap zone in southern Yukon so specimens in this area must be carefully studied to make the correct species determination.

Type Material: "USA: WA: Mt. Baker-/ Snoqualmie NF: Mt. Baker:/ SilverFirCampground; 2012ft./ 48.904950 N, $121.697917^{\circ}$ W;/ 8.vii.2010; M.M.Locke”, “J. Skevington/ Specimen \#/ 23708”, "HOLOTYPE/ Dasysyrphus/ occidualis/ Locke \&/ Skevington", $\widehat{O}$, deposited in the Canadian Collection if Insects, Arachnids and Nematodes (CNC), Ottawa, Ontario, Canada.

Material Examined:

Canada: Alberta: Kananaskis, Forest Experimental Station Seebe, [51.100879, -115.087692], 15.vi.1968, $q$, CNCD 5014, H.J. Teskey (CNC). BANFF NATIONAL PARK: Banff, [51.180275, -115.568433], 15.vii.1922, 3 , CNCD 13621-13623, C.B.D. Garrett (CNC); + , JSS 19432, N.B. Sanson (CNC); 11.vii.1951, + , CNCD 13619, (CNC). British Columbia: CATHEdRAl Prov. PARK: Glacier Lake, [49.055785, -120.207299], 6.vii.1986, $q$, RBCM ENT 9882357, R.A. Cannings (RBCM); fen, Lk. of the Woods trail, [49.08, -120.18], 26.vii.1988, 9 , JSS 20186, S.G. Cannings (UBCZ). Squamish, Diamond Head Trail, [49.811126, -123.07434], 1219m, 11.viii.1953, ㅇ, CNCD 13610, W.R.M. Mason (CNC). Duffey L. Blowdown Cr., lake S. of Gott Peak, [50.40416667, 122.3416667], 21.vii.1988, + , RBCM ENT 9918197, C.S. Guppy (RBCM). Cornwall Hills Lookout, [50.7, 121.5], 2037m, 14.vi.1989, §̂, RBCM ENT 990626, R.A. Cannings \& C.S. Guppy (RBCM). KoOtenAY NATIONAL PARK: Daer-Pitts Aspen Control 2, [50.776662, -115.936917], 17.vi.-2.vii.2000, 2へ, CNCD 30908, 30909, 9 , CNCD 30903, G. Gareau (CNC); Floe Lake, [51.054, -116.137], 1981m, 9.viii.1955, 9 , CNCD 13611, J.R.W. McGillis (CNC). Mount ReVELSTOKe NATIONAl PARK: [51.035979, -118.142509], 1828m, 26.vii.1952, , CNCD 13612, G.P. Holland (CNC); 15.viii.1952, q, CNCD 13613, G.J. Spencer (CNC); Mount Harry, [51.035979, -118.142509], 2073m, 8.viii.1952, +, CNCD 13614, G.J. Spencer (CNC); Mt. Revelstoke, [51.05, 118.1333333], 1829m, 7.viii.1952, +, RBCM ENT 99188105, G.P. Holland (RBCM); Eva Lake Trail, [51.079905, -118.108837], 1828m, 6.viii.1952, क, CNCD 13615, G.J. Spencer (CNC). SKENNA-QUEEN CHARLOTTE R.D.: Tlell, Queen Charlotte Islands, [53.562591, -131.93235], 25.v.1957, §̂, CNCD 13620, E.E. MacDougall (CNC). NORTHERN Rockies R.D.: Summit Lake, Mile 392 of Alaska Highway, [58.648201, -124.666912], 1372m, 1.vii.1959, 9 , CNCD 13603, R.E. Leech (CNC); 1.vii.1959, \&, CNCD 13605, 2-4.vii.1959, 3 + , CNCD 1360613608, 6.vii.1959, + , CNCD 13604, E.E. MacDougall (CNC). Ft. Nelson, [58.804594, -122.697436], 4.vii.1949, + , JSS 19993, J.K. Morie (UBCZ). Liard R. hotsprings, [59.425991, -126.096398], 23.vii.1987, 3 + , JSS 2017620178, S.G. Cannings (UBCZ). Fireside, [59.666676, -127.14242], 24.v.1980, CNCD 60083, Bruce Gill (CNC). 7 miles N Lions Bay, 18.v.1979, ô, CNCD 5463, G.F. Hevel (CNC). Spanish Hills, Galiano Island, 10.v.1980, CNCD 60094, G.G.E. Scudder (CNC). Yukon Territory: Carcross Dunes at Bennett L. beach, [60.17066, -134.71809], 666m, 25.vi.2009, + , JSS 20819, Lee Mennell (RBCM). Takhini R., west dunes 6.8km NNE of Kusawa L. outlet, [60.66824, -136.07664], 19.vi.2009, , JSS 20820, S. Cannings (RBCM). Sheldon Lake, [62.616763, 131.266603], 914m, 21.vii.1960, 9 , CNCD 13561, J.E.H. Martin (CNC). DEMPSTER HIGHWAY: North Klondike River, Km 64 [64.45056, -138.218356], 9.vi.1980, 今, JSS 18376, R.J. Cannings (CNC). United States of America: Alaska: MATANUSKA-SUSITNA Co.: Matanuska, [61.541945, -149.229674], 29.v.1944, ๆ, JSS 19431, J. Chamberlin (CNC). Nome Area, Mile 17 of Kougarok Road, [64.70611111, -165.2972222], 26-28.vi.2005, ㅇ, CNCD 30899, J.\&R. Skevington (CNC). Colorado: Pike's Peak Summit, [38.840342, -105.045006], 14.viii.1977, +, USNM ENT 258091, A.B. Gurney (USNM). GunNISON Co.: Ragged Mountain, [39.118885, -107.407678], 20.vi.1950, J , CNCD 26345, C.A. Downing (CNC). CleAR CReEK Co.: Mount Evans, [39.645575, -105.594897] 22.vii.1961, , CNCD 26335, J.G. Chillcott (CNC); 3.viii.1961, 2q, CNCD 26330, 26331, S.M. Clark (CNC); 3.viii.1961, 2 q, CNCD 26332, 26333, W.R.M. Mason (CNC); 4.viii.1961, §, CNCD 26342, J.R. Stainer (CNC); 10.viii.1961, +, CNCD 26334, C.H. Mann (CNC); Timberline, Mount Evans, 3566m, 22.vii.1961, + , CNCD 26336, C.H. Mann (CNC); 22.vii.1961, †, CNCD 26337, B.H. Poole (CNC); Echo Lake, Mt. Evans, [39.658085, - 
105.6035], 3231m, 22.vii.1961, +, CNCD 26338, J.G. Chillcott (CNC); Doolittle Ranch, Mt. Evans, [39.675739, 105.601348], 2987m, 12.viii.1961, +, CNCD 26339, J.R. Stainer (CNC); Guanella Pass, [39.594992, 105.711109], 3536m, 14.vii.1961, , CNCD 26340, S.M. Clark (CNC). Brainard Lake Rec. Area 4mi W of Ward

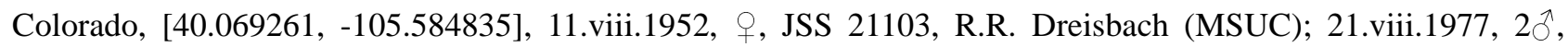
USNM ENT 258062, 258063, A.G. Lavallee (USNM). Cameron Pass, [40.520816, -118.227668], 28.vii.1954, ð, OSAC 133386, Chas. L. Fluke (OSAC). North Park, [40.73, -106.18], 1.vii.1932, \&, JSS 20665, (CSUC). Washington: MT. RANIER NATIONAL PARK: Paradise Valley, [46.782709, -121.727952], 15.vii.1920, §, JSS 23880, 18.vii.1920, 7ð, JSS 23722, 23888, 23889, 23893, 23894, 23900, 23904, 19.vii.1920, $2 \hat{\jmath}$, JSS 23886,

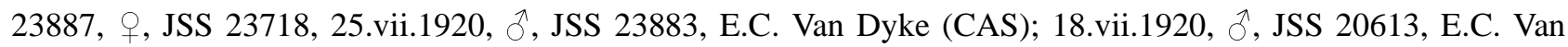
Dyke (EMEC); Carbon River near Ranger station, [46.85, -121.75], 15.viii.1999, + , JSS 20681, B. Kondratieff (CSUC); Louis Lake, Fryingpan Cr., Sunrise Rd., [46.85, -121.75], 17.vi.2004, Õ, JSS 20804, B. Kondratieff, J. Schmidt, J. Owens (CSUC). Seattle, [47.60621, -122.332071], 16.vi.1901, $q$, OSAC 133444, (OSAC). MT. BAKER-SNOQUAlmie NATIONAL FOREST: Mt. Baker, Picture Lake, [48.866217, -121.676533], 1273m, 7.vii.2010, ○, JSS 23706, +, JSS 24625, A. Young (DEBU); Silver Fir Campground, [48.90495, 121.697917], 613m, 8.vii.2010, §, JSS 23708, 9.vii.2010, , CNCD 35311, 60043, M.M. Locke (CNC); 9.vii.2010, CNCD 60046, CNCD 60047, A. Young (CNC). Wyoming: Wyoming, [43.084281, -107.556417], 1952, ㅇ, CNCD 26329, F.M. Hull (CNC). Yellowstone National Park, [44.587719, -110.537673], 20.vii.1925, §̂, CNCD 26343, A.A. Nichol $(\mathrm{CNC})$.

\section{Dasysyrphus pacificus (Lovett)}

Figures: 13A-D, 21C

Synonyms and References:

Syrphus pacifica Lovett 1919: 245 (in (Cole \& Lovett 1919); original description)

Metasyrphus pacifica (Lovett):

Fluke 1933: 116 (key, redescription and transfer to Metasyrphus)

Dasysyrphus pacificus (Lovett):

Stone et al. 1965: 564 (catalogue and transfer to Dasysyrphus)

Dasysyrphus pauxillus (Williston):

Vockeroth 1986: 203 (in part; synonymy)

Vockeroth 1992: 68 (in part; key and redescription)

Diagnosis: Abdominal maculae of tergites $3 \& 4$ slightly arcuate, uniform in thickness and do not cross abdominal margin (Figs 13A \& B); very similar in appearance to D. pauxillus (Fig. 14A), D. nigricornis (Figs 11A \& B) and D. laticaudus (Fig. 8A). Wing typically much more bare than any of the three aforementioned species, with cells br and bm with large dense areas (Fig. 13C). Male gonostylus with narrow, wavy projection on posterodorsal surface (arrow, Fig. 13D). Due to an extremely similar habitus, it is difficult to distinguish D. pacificus from D. pauxillus. Male genitalia should be used to conclusively identify specimens, especially in the overlap zone of these species' ranges in southern British Columbia.

Redescription:

Body Length: $5.0-8.5 \mathrm{~mm}$; Wing Length: $5.0-7.7 \mathrm{~mm}$

Head: Frons dark with light pollenose fascia (in males it runs along ventral edge of where eyes meet, in female it is $1 / 2$ the length between the antennae and ocelli) and dark pile; face light with dark vitta $1 / 4$ the width of the face, reaching antennal socket, face with dark pile; gena dark with some light pollen ventral to eye, dark pile dorsally and light pile ventrally; occiput dark, covered in light pollen, pile light with some dark pile dorsally; scape, pedicel and flagellomere light to dark.

Thorax: Scutum dark, may appear shiny or metallic, pile light; scutellum light to dark with darker anterior and lateral edges, light pile with some dark pile posteriorly; wing cell br bare above spurious vein and usually on basal half, bm bare medially or basal half, cells $\mathrm{c}$ and $\mathrm{r}_{1}$ bare at base or with at least small bare areas at base, cup call has small bare areas along vein CuP, wing less frequently completely microtrichose (Fig. 13C); haltere light to dark; pro- and mesofemora $1 / 3-1 / 2$ dark basially, $1 / 2-2 / 3$ light apically, metafemur $2 / 3-3 / 4$ dark basially, $1 / 4-1 / 3$ light apically, tibiae light, metatibia with dark band $1 / 4$ of the way from the apex, tarsi light, sometime dark anteriorly. 


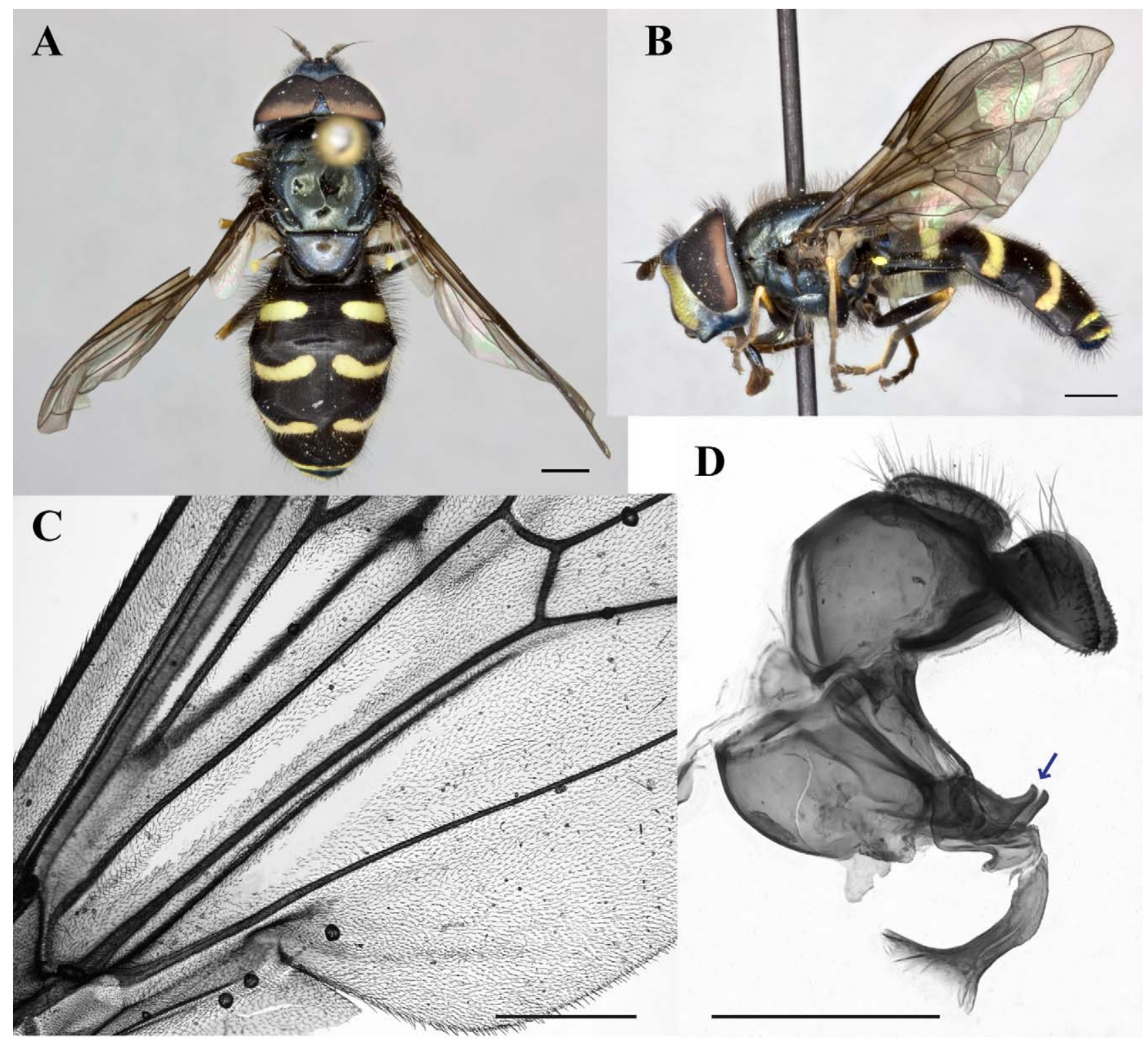

FIGURE 13. Dasysyrphus pacificus: A: male (CNCD 35314) dorsal habitus; B: male (CNCD 35314) lateral habitus; C: wing base (CNCD 60058); D: lateral view of male (CNCD 26435) genitalia. Dorsal and lateral habitus scale bar $=1 \mathrm{~mm}$, genitalia and wing scale bar $=500 \mu \mathrm{m}$.

Abdomen: Maculae on tergite 2 large, slender and oval, $1 / 3-1 / 2$ width of tergite, maculae on tergites $3 \& 4$ are slightly arcuate, uniform in thickness, with out a distinct swelling medially, maculae do not reach abdominal margin (Figs 13A \& B); sternites light with dark fasciae.

Male Genitalia: Surstylus more or less triangular in shape in lateral view, flattened posteriorly, long pile on dorsal, laterodorsal and posterodorsal sides, row of spines on posteromedial edge; cercus oval with long pile over entire surface; gonostylus triangular-shaped with narrow, wavy projection on posterodorsal surface projecting posterodorsally, pile on dorsal surface; basiphallus elongate, basally bent at 90 degree angle towards dorsum, apical end curved ventrally with a widened apex and is partly membranous dorsally, with spines on posterodorsal side; distiphallus elongate, apical end flared out into horn, which is mostly sclerotized but membranous at apex with few minute setulae dorsally, basally bent towards dorsum and usually greatly enlarged at bend with a triangular projection, projecting ventrally (Fig. 13D).

Intraspecific variation: Distiphallus sometimes without triangular projection basally. Abdominal maculae on tergites $3 \& 4$ rarely meet medially, and if so, barely touch.

Etymology: Pacificus is Latin for peaceful or peace-making, but more probably was named so because this species is found along the Pacific coast of North America. 
Distribution: Southwestern USA (CA, NV, OR, WA) and southwestern Canada (BC); Cascades and Sierra Nevada Mountain Ranges (Fig. 21C).

Ecology:

Collected from April-July, but more commonly in May and June, at elevations of 475-3100m. Recorded from willow (Salix Linnaeus, Salicaceae) and bitterbush (Purshia de Candolle ex Poiret, Rosaceae).

Discussion: Dasysyrphus pacificus is hereby resurrected from synonymy with Dasysyrphus pauxillus (synonymized by Vockeroth (1986)). The type specimen of this species could not be examined as it is out on loan to another individual. However, based on the written description and distribution of D. pacificus (Cole \& Lovett 1919) the authors are confident that the individuals examined were of this species. The range of pacificus is from southern British Columbia, south to California, in the Cascades and Sierra Nevada mountain ranges. The type specimen is from Oregon, where it is the only species of the pauxillus s.l. in this range.

Type Material: "Holotype (No. 502), male, in Museum of the California Academy of Sciences, collected at Corvallis, Ore., May 17, by A. L. Lovett" (Cole \& Lovett 1919). (not examined)

Material Examined:

Canada: British Columbia: Bear Mountain, [49.300555, -121.740556], 6.v.1920, §, CNCD 13743, (CNC). EAST KoOTENAY R.D.: Cranbrook, [49.517983, -115.761504], 19.v.1920, đ, CNCD 13748, C.B.D. Garrett (CNC); 27.iv. O, RBCM ENT 99188108, H.R. Foxlee (RBCM). 7 miles N Lions Bay, North of Vancouver, 18.v.1979, ô, CNCD 5464, G.F. Hevel (USNM). United States of America: California: RIVERSIDE Co.: Dark Canyon N of Idyllwild, [33.81666667, -116.7166667], 24.v.2003, CNCD 8472, J. Skevington (CNC). SAN BERNARDINO Co.: Upper Santa Ana River, [34.091253, -117.120741], 3.vi.1947, o, CNCD 26415, G.H. \& J.L. Sperry (CNC). 1 km NW Wrightwood, Big Pines Hwy, [34.38138889, -117.6716667], 1974m, 21-28.v.2005, 5^, JSS 20974, 20976-20978, 20980, 29, JSS 20975, 20979, A.R. Cline \& S.L. Winterton (MHPC). Oakhurst, [37.328, -119.649315], 1.vi.1942, क, JSS 20598, E.C. Linsley (EMEC). TuOLuMNE Co.: Mather Site, Buck Meadows, [37.880173, -119.856977], 1970, ð, CNCD 26437, 4, CNCD 26404-26407, A.R. Moldenke (CNC). MARIN Co.: Lily Pond, Alpine Lake, [37.953803, -122.634977], 457m, 25.v.1970, +, CNCD 26414, 11.iv.25.v.1971, § , CNCD 26344, D.D. Munroe (CNC). CALAVERAS BIG TREeS SP: S. grove, banks of Beaver Creek, MT\#2, [38.26166667, -120.2577778], 1375m, 22.v.-11.vi.2007, 69, JSS 20966-20970, 20972, A.R. Cline \& P.H. Kerr (MHPC). INDIAN GRINDING Rock SP: dry wash nr. S. Nature Trail MT \#2, [38.41666667, -120.6333333], 715m, 5.iv.-24.iv.2007, JSS 20981, q, JSS 20992, P. Kerr \& M. Hauser (MHPC); firebreak nr. envtl camp MT3, [38.41861111, -120.635], 715m, 24.iv.2007 24.v.2007,, , JSS 20971, P. Kerr \& M. Hauser (MHPC). Sonora Pass, [38.53666667, -119.6855556], 3100m, 21.vi.2007, q, JSS 20963, S.M. Blank (MHPC). Wright's Lake, [38.84913, -120.2318], 2.vii.1948, § , JSS 20597, D. Carter (EMEC); 2.vii.1948, ㅇ, JSS 20601, L.W. Quate (EMEC). Placer County, [39.090423, -120.803069], 1524m, iv,, , JSS 19511, W.M. Davidson (CNC). Tahoe City, Alpine Meadow Road Jenkinson Reservoir, [39.42138889, -120.3333333], 2200m, 14.vi.2007, §̂, JSS 20957, ᄋ, JSS 20958, S.M. Blank (MHPC). Sinkyone Wilderness State Park, [39.83583333, 123], 28m, 23.iii.2003, ô, JSS 20797, J. \& A. Skevington (CNC). PlumAS Co.: Buck's Lake, [39.890961, -121.185778], 13.v.1949, , , CNCD 26409, P.D. Hurd (CNC), 4\%, CNCD 26432-26435, + , CNCD 26410, W.W. Middlekauff (CNC); 23.vi.1949, 2 \%, CNCD 26412, D.

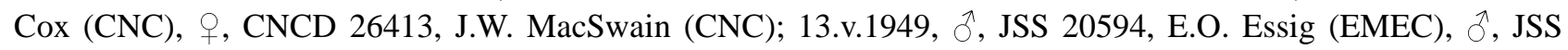
20595, , JSS 20603, P.D. Hurd (EMEC); 23.vi.1949, 2 , JSS 20599, 20600, J.W. MacSwain (EMEC). TeHAMA Co.: 60 kilometers North East of Chico on Road 32, [40.19611111, -121.5213889], 1100m, 15.v.2010, JSS 25002, 25003, 25005-25009, D. Striley, M. Hauser (CSCA). LASSEN Co.: Susan River Campground, [40.492316, 121.094484], 9.vii.1949, + , CNCD 26411, A.T. McClay (CNC). SHASTA Co.: Viola, [40.517921, -121.680971], 19.v.1941, Ô, CNCD 26436, + , CNCD 26408, E.G. Linsley (CNC). LASSEN NATIONAL PARK: Manzanita Lake, [40.534513, 121.56655], 8.vi.1941,, , JSS 20596, C.D. Michener (EMEC),, , JSS 20602, Arthur J Walz (EMEC). Ryan Creek, 17.v.1938, $q$, CNCD 106796, N.F. Hardman (CNC). San Bernardino Mountains; Up Sta. Ana River, 15.vi.1955, + , JSS 23775; 1957, + , JSS 26926, A.L. Melander (USNM). Nevada: WASHOE Co.: Little Valley, [39.806851, -119.951585], 4.vi.1981, JSS 25100, R.W. Rust (EMUS). Oregon: KLAMATH Co.: Lake of the Woods, [42.368634, -122.208482], 22.vi.1975, JSS 25082-25086, 25088-25095, G.F. Knowlton (EMUS), o, CNCD 5457, G.F. Knowlton (USNM); Summit Lake, [43.454905, -122.118766], 7.vii.1952, ð̊, CNCD 26442, E.R. Jaycox (CNC). Deschutes Co.: Camp Abbot, [43.874555, -121.435449], 4.vi.1944, + , CNCD 26401, P.H. Arnaud (CNC). Bellfountain, [44.363611, -123.355278], 27.v.1922, Oૈ, OSAC 133389, 133391, A.L. Lovett (OSAC). BENTON Co.: Corvallis, [44.564564, -123.262033], v.1977, §,, JSS 19507, A.L. Lovett (CNC). 
Washington: WenATChe NATIONAL ForEST: White Pass Trail, [46.643317, 121.378783], 1345m, 6.vii.2010, CNCD 60054, A. Young (CNC), ô, CNCD 35314, + , CNCD 35313, M.M. Locke (CNC). Mount Rainier,

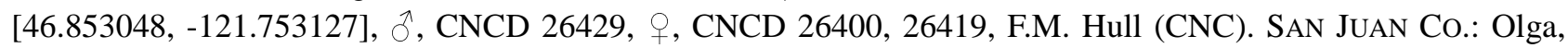
[48.619548, -122.835459], 18.v.1910, + , JSS 19504, (CNC). MOUNT BAKER-SNOQUALMIE NATIONAL ForeST, Picture Lake, [48.866217, 121.676533], 1255m, 8.vii.2010, CNCD 60058, A. Young (CNC). Price Co.: Pleasant Valley, [48.90667, -122.70333], 21.v.1977, JSS 25097, T.L. Whitworth (EMUS).

\section{Dasysyrphus pauxillus (Williston)}

Figures: 14A-D, 18A \& D, 21D

Synonyms and References:

Syrphus pauxillus Williston 1887: 74 (original description)

Metasyrphus pauxillus:

Fluke 1933: 115 (key, redescription and transfer to Metasyrphus)

Dasysyrphus pauxillus:

Stone et al. 1965: 564 (catalogue and transfer to Dasysyrphus)

Vockeroth 1986: 203 (discussion)

Vockeroth 1992: 68 (key and redescription)

Speight 2011: 70 (discussion)

Diagnosis: Abdominal maculae of tergites $3 \& 4$ slightly arcuate, uniform in thickness and do not cross abdominal margin (Figs 14A \& B); very similar in appearance to D. pacificus (Fig. 13A), D. nigricornis (Figs 11A \& B) and D. laticaudus (Fig. 8A). Wing typically densely microtrichose, sometimes with bare areas in cells $\mathrm{r}_{1}$, br, bm and/or c (Fig. 14C). Male gonostylus with projection on posterodorsal surface straight (Fig. 14D). Due to an extremely similar habitus, it is difficult to distinguish D. pacificus from D. pauxillus. Male genitalia should be used to conclusively identify specimens, especially in the overlap zone of these species' ranges in southern British Columbia.

Redescription:

Body Length: 5.3-9.7mm; Wing Length: 5.2-9.5mm

Head: Frons dark with light pollenose fascia (in males it runs along ventral edge of where eyes meet, in females it is $1 / 3-1 / 2$ the length between the antennae and ocelli with a separation medially and edges triangular to rounded (Fig. 18A)) and light to dark pile; face light with dark vitta $1 / 4-1 / 3$ the width of the face, coming close to antennal socket if not reaching it, face with dark pile lateral to the eye, some females with varying amounts of light pile interspersed with dark pile; gena with light to dark pile; occiput dark, covered in light pollen, pile light; scape and pedicel light to dark, flagellomere dark with lighter base.

Thorax: Scutum dark, may appear shiny or metallic, pile light to dark; scutellum light to dark with darker lateral edges, pile on female mostly light with some dark, male mostly dark pile some with light interspersed throughout; wing cell $r_{1}$ with the base bare or very small areas at base bare, br, bm and c may all be entirely microtrichose or they may have bare areas along spurious vein, along the middle of the cell form the base to $3 / 4$ or small areas at base, respectively (Fig. 14C); haltere light; pro- and mesofemora $1 / 3-2 / 3$ dark basally, $1 / 3-2 / 3$ light apically, metafemur $2 / 3-3 / 4$ dark basally, $1 / 4-1 / 3$ light apically, tibiae light, meso- and metatibiae with dark band $1 / 4$ of the way from the apex, tarsi light with dark anterior side.

Abdomen: Maculae on tergite 2 large and oval, lateral edge tends to be more flattened than medial edge, female usually with very small, pointed, anterolateral projection, but it never reaches the edge of the tergite, maculae on tergites $3 \& 4$ are oblique, fairly straight and uniform in width, sometimes with medial edge slightly swollen, maculae do not reach abdominal margin (Figs 14A \& B); sternites light with dark fasciae of varying thickness (Fig. 18D).

Male Genitalia: Surstylus more or less triangular in shape in lateral view, flattened posteriorly, long pile on dorsal, laterodorsal and posterodorsal sides, row of spines on posteromedial edge; cercus oval with long pile over entire surface; gonostylus boot-shaped but more narrow apically than basally, with projection on posterodorsal surface, projecting dorsally, pile on dorsal surface; basiphallus elongate, basally bent at a slightly more than 90 degree angle towards dorsum, apical end curved ventrally, but does not greatly extend ventrally and is partly 
membranous dorsally, with spines on posterodorsal side; distiphallus elongate, apical end flared out into horn, which is mostly sclerotized but membranous at apex, with no setulae dorsally, basally bent towards dorsum and usually greatly enlarged at bend with a triangular projection, projecting ventrally (Fig. 14D). Extremely similar to D. laticaudus (Fig. 8C).

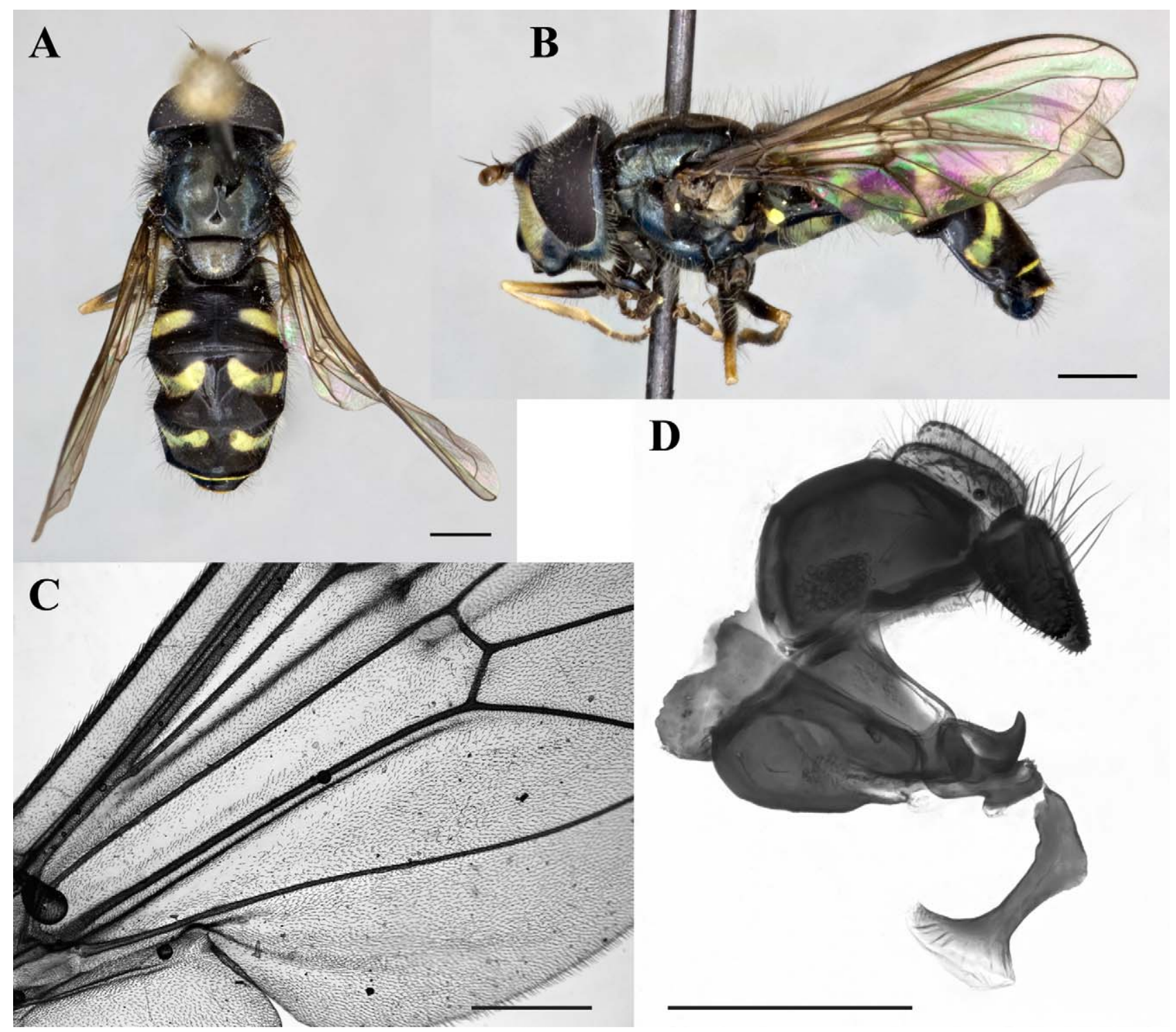

FIGURE 14. Dasysyrphus pauxillus: A: male (JSS 24616) dorsal habitus; B: male (JSS 24616) lateral habitus; C: wing base (CNCD 13830); D: lateral view of male (CNCD 13746) genitalia. Dorsal and lateral habitus scale bar $=1 \mathrm{~mm}$, genitalia and wing scale bar $=500 \mu \mathrm{m}$.

Intraspecific variation: Wings are typically densely microtrichose with cell $r_{1}$ having bare areas at base ranging from entire base bare to very small areas at base being bare, cells br, bm and c may all be entirely microtrichose or they may have bare areas; female usually have a very small, anterolateral projection on maculae of tergite 2, males do not have this projection.

Etymology: From the Latin pauxillus, meaning small.

Distribution: Rocky Mountains; Western Canada (AB, BC, MB, YT) and western USA (AK, CO, ID, NM, UT, WY) (Fig. 21D).

Ecology: Collected from March-July, but more commonly collected in June. Collected at elevations of 14$3505 \mathrm{~m}$. Habitats collected from are listed as "moraine lake", "grassy lakeshore", "over stream in fir forest", "on tundra", "spruce forest" and "Pinus-Salix forest". It has been collected from the following plant species: common cow parsnip (Heracleum maximum W. Bartram, Apiaceae), blackberry (Rubus Linnaeus, Rosaceae), willow (Salix 
Linnaeus, Salicaceae), Canada gooseberry (Ribes oxyacanthoides Linnaeus, Grossulariaceae) and spruce (Picea A. Dietrich, Pinaceae).

Discussion: Many authors have used the name pauxillus in the Palaearctic. During the course of this revision few specimens from that region were examined and no DNA evidence could be studied. Therefore, we cannot comment on whether the use of this name is appropriate in the Palaearctic. However, based on the geographic breakdown of pauxillus and its allies (laticaudus, pacificus and nigricornis) in the Nearctic it seems likely that only nigricornis is Holarctic. European and Asian specimens should be studied in greater depth, using both morphology and DNA, to confirm this suspicion.

Due to the widespread use of the name pauxillus much confusion exists over the concept of this species. Many Holarctic species have been named which have an extremely similar habitus to pauxillus. The main reason for such confusion is that the holotype specimen is lost (Fluke 1933). In Williston's (1887) original designation he describes one female from New Mexico. He does not indicate where this specimen is deposited. The only other information that is provided is that the specimen was collected by G.F. Gaumer. In Fluke's (1933) revision of Metasyrphus he indicates that he was unable to locate the type for examination. No record exists in the literature of any author examining Williston's specimen; either Williston's species description was used or specimens determined by other researchers were used for comparison. Dasysyrphus pauxillus was described in 'Synopsis of the North American Syrphidae', Williston's PhD dissertation (Beckemeyer 2009). The specimens from his dissertation were donated to the USNM (Flint et al. 1976, F.C. Thompson, pers. comm.). According to Thompson (pers. comm.) the type specimen is not in the USNM collection today and it is not known what happened to it. Williston worked in Kansas and Chicago until his death, after which his collection was donated to the American Museum of Natural History (AMNH). Byers et al. (Byers et al. 1962) do not list pauxillus as a type in the Kansas collection and the specimen is not listed in the type database of the AMNH (The American Museum of Natural History 2005). A neotype is designated here to bring stability to the name pauxillus. This will create a solid concept for this species, allowing for better reconciliation of closely related species. The specimen used in the original designation provided a locality of 'New Mexico'. The neotype specimen was chosen from a series of males from Utah, as the two specimens from New Mexico were a female and a male in poor condition. This is a locality that is not overlapped by the other species with a similar habitus to pauxillus (pacificus, laticaudus and nigricornis). The neotype varies from Williston's description in a few characters that are variable in many Dasysyrphus species. Also, Williston's description was of a female and the neotype is male, which may account for some of the variation. The dorsum of the scutum in the neotype is covered by mainly dark pile, Williston's description states the pile is light yellowish. This character is variable within most Dasysyrphus species and often males have more dark pile and females have more light pile on the scutum. The face is also not projecting to the extent described by Williston. The face seems to project slightly more in females than males, but in most specimens the distance between the antennae and the tip of the tubercle is more or less equal to the distance from the antennae to the ocelli. The specimen matches the description in all other characters. The Neotype is a male from Tony Grove Lake, Wasatch-Cache National Forest, UT, USA, collected on 1.vii.2010 by M.M. Locke. It is deposited in the CNC and databased with the number Jeff Skevington Specimen 24616.

Type Material: "USA:UT:Wasatch-CacheNF:/ Tony Grove Lake;/ $41.893136^{\circ} \mathrm{N}, 111.641841^{\circ} \mathrm{W} ; /$ 1.vii.2010; M.M.Locke", “J. Skevington/ Specimen \#/ 24616”, "NEOTYPE/ Syrphus/ pauxillus/ Williston”, "designated by/ Locke \&/ Skevington/ 2013"; Oे, deposited in the Canadian National Collection of Insects, Arachnids and Nematodes, Ottawa, Ontario, Canada.

\section{Material Examined:}

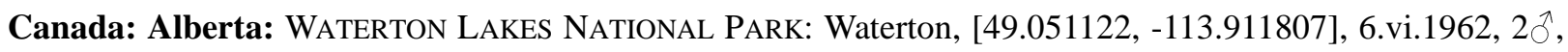
CNCD 13764, 13765, 4, CNCD 13836-13839, W.R.M. Mason (CNC), 2 + , CNCD 13834, 13835, K.C. Herrmann (CNC). KANANASKIS: 25 km WNW Bragg Creek Powderface trail Rd., [51.02166667, -114.9016667], 8.vi.2001, 今ે, RBCM ENT 6006051, C.J. Borkent (RBCM); Forest Experimental Station Seebe, [51.100879, 115.087692], 2.vi.1968, ๆ, CNCD 13840, 13.vi.1968, +, CNCD 13841, 15.vi.1968, +, CNCD 13842, H.J. Teskey (CNC). 30 miles West of Calgary, [51.04575, -113.631333], 3.vi.1973, CNCD 60100, G.G.E. Scudder (CNC). BANFF NATIONAL PARK: Banff, [51.180275, -115.568433], 27.v.1925, ô, CNCD 13762, E. Hearle (CNC); 2.vi.1922, §̊, CNCD 13763, 3ㅇ, CNCD 13845-13847, 9.vi.1922, o, CNCD 13849, 3.vii.1922, ㅇ, CNCD 13848, C.B.D. Garrett (CNC); 2.vi.1914, , , JSS 20605, N.B. Sanson (EMEC); 30.v.1948, + , UASM\# 149024, 2.vi.1948, , UASM\# 149025, E.H. Strickland (UASM); Mount Eisenhower, [51.298694, -115.925724], 3.vi.1968, 20, 


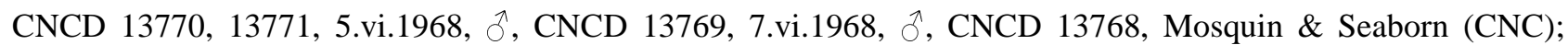
Moraine Lake, [51.324073, -116.184418], 2256m, 20.vii.1955,, , CNCD 13850, J.R. McGillis (CNC); 8 km West of Lake Louise, [51.413684, -116.306046], 31.v.1992, +, JSS 20801, A. Borkent (CNC); Lake Agnes, [51.415101, -116.247314], 2073m, 10.vii.1925, Ô, JSS 19508, O. Bryant (CNC); Snow Creek Pass, [51.60524, -115.808617], 2256m, 20.vii.1962, , CNCD 13844, K.C. Herrmann (CNC); Peyto Lookout, [51.717631, -116.508919], 2316m, 23.vii.1962,, , CNCD 13843, W.R.M. Mason (CNC). Edmonton, 12.v.1924, ô, JSS 23724, Owen Bryant (CAS); Laggen, Lake Agnes, 10.vii.1925,, , JSS 23714, O. Bryant (CAS). Edmonton; W. Hawrelak Park, 640m, 3.v.2005, 3 ${ }^{\top}$, JSS 25540-25542, W. van Steenis (WVSC). Pincher Creek; Beauvais Lake, 19.v.1989 23.v.1989, $^{\text {, JSS }}$ 25550, C. v. Nidek (WVSC). British Columbia: Victoria, Mt. Work, [48.53, -123.47], 26.v.1982, §, RBCM ENT 99188111, R.A. Cannings (RBCM). Galiano I. North End, [48.92, -123.42], 29.iii.1987, §, JSS 20184, G.G.E. Scudder (UBCZ). WATERTON LAKES NATIONAL PARK: Cameron Lake, [49.011457, -114.049238], 17.vi.1956, 9 ^, CNCD 13754-13761, 13767, 9 , CNCD 13822-13830, 18.vi.1956, ㅇ, CNCD 13831, 19.vi.1956, 2 , CNCD 13832, 13833, E.E. Sterns (CNC). CENTRAL KoOTENAY L.D.: Robson, [49.333015, -117.692871], 21.iv.1947, ô,

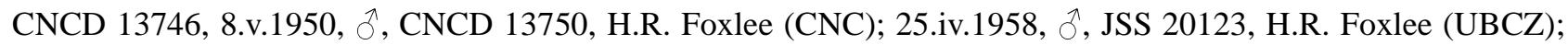
Boswell, [49.414407, -116.746741], 9.v.1958, §, CNCD 13742, H. \& A. Howden (CNC). SQUAMISH-LiLlooET R.D.: Meager Creek Hot Springs, [50.561617, -123.486344], 14.v.1987, Ô, JSS 18370, C.S. Guppy (CNC). Kootenay National Park: Daer-Pitts Aspen Control 1, [50.95, -116.0333333], 3.vi.2000 17.vi.2000, CNCD 7969, G. Gareau (CNC); Daer-Pitts Aspen Control 2, 17.vi.2000 2.vii.2000, $\uparrow$, CNCD 30906, G. Gareau (CNC). 32 miles South West of Terrace, [54.194076, -129.140296], 30.5m, 6.vi.1960, +, CNCD 13819, G.E. Shewell (CNC); 6.vi.1960, \&, CNCD 13820, 11.vi.1960, §ิ, CNCD 13753, B. Heming (CNC). Shames, 18 Miles South West of Terrace, [54.409648, -128.935301], 23.vi.1960, ㅇ, CNCD 13818, C. H. Mann (CNC). Kleanza Creek, Near Terrace, [54.597897, -128.386241], 76.2m, 29.vi.1960,, , CNCD 13817, B. Heming (CNC); 30.vi.1960, $q$, CNCD 13821, J.G. Chillcott (CNC). Atlin, [59.5775, -133.69236], 670.56m, 2.vi.1955, ô, CNCD 13751,.vii.1955, , CNCD 13809, H.J. Huckel (CNC); 20.vi.1955, วิ, CNCD 14358, ${ }^{2}$, CNCD 13808, B.A. Gibbard (CNC). Manitoba: 26km SE Churchill; Twin Lakes, [58.63, -93.819], 14m, 19.vii.2009, ㅇ, 09PROBE 197, 22.vii.2009, o, 09PROBE 255, Arctic Ecology 2009 (CNC). Yukon Territory: Snafu Creekl, [60.13333333, -138.8], 22.vi.1982, CNCD 60079, S.G. Cannings,R.D. Wilkie, L. Vasington (CNC). Whitehorse, [60.71965, -135.052213], 6.vii.1988, , CNCD 5812, F. Brodo (CNC). Simpson L. $81 \mathrm{~km} n$ Watson L., [60.75, -129.25], 15.vi.1984 1.ix.1984, + , JSS 20770, S. \& J. Peck (CNC). Nines Creek, 3 km West of Alaska Highway, [61.18333333, -139.7], 4.vi.1981, CNCD 60072, C. Guppy (CNC). La Force Lake, [62.683333, -132.333333], 914m, 26.vi.1960, , CNCD 13585, 10.vii.1960, +, CNCD 13728, E.W. Rockburne (CNC). United States of America: Alaska: Matanuska-Susitna Co.: Matanuska, [61.541945, -149.229674], 12.vi.1944, + , JSS 19502, J. Chamberlin (CNC). Colorado: Rocky Gulch, [37.817035, -107.579606], 3444m, 6.xxii.2002, §, JSS 20810, C. Slater (CSUC). Monarch Pass, 2mi W Garfield, [38.501433, -106.327747], 3048m, 19.vi.1985, ð, USNM ENT 258074, David R. Smith (USNM). Rock Cr., May Mus., [38.705655, -104.837421], 8.v.1996,, , JSS 20808, D. Leatherman (CSUC). Tenmile Range, unamed Cr. avalanche chute W side, [39.425, -106.111], 3200m, 15.vii.1998 17.vii.1998, §., JSS 20694, S. Fitzgerald \& A. Foley (CSUC). CleAR CREek Co.: Mt. Evans, Echo Lake Campground, [39.65622, 105.595042], 329m, 29.vi.2010, CNCD 60035, M.M. Locke (CNC); Mt. Evans, Echo Lake, [39.658085, 105.6035], 3231m, 13.vii.1961, +, CNCD 26416, C.H. Mann (CNC); 29.vi.2010, , JSS 24618, M.M. Locke (CNC); 29.vi.2010, +, CNCD 35312, A. Young (CNC); Mt. Evans, Doolittle Ranch, [39.675739, -105.601348], 2987m, 13.vii.1961, +, CNCD 26417, W.R.M. Mason (CNC). BoulDER Co.: Nederland, Science Lodge, [40.031645, -105.533886], 2896m, 4.vii.1961, , CNCD 26418, B.H. Poole (CNC); Niwot Ridge, Near Ward, [40.069933, -105.607397], 3444m, 4.vi.1961, đ̂, CNCD 26440, 28.vi.1961, đ, CNCD 26439, C.H. Mann (CNC). North Park, [40.73, -106.18], 1.vii.1932,, , JSS 20746, (CSUC). Rawah Wilderness, Blue Lake Trail near Fall Creek, [40.76944444, -105.9894444], 2926m, 20.vi.1998, §̃, JSS 20693, S. Fitzgerald \& A. Foley (CSUC). Cherokee Park, [40.90972, -105.47917], 30.vii.1913, 9 , JSS 20713, Chas L. Fluke (CSUC). MinERAL Co.: Continental Divide, 3292m, 20.vi.1919, Ô, JSS 19512, (CNC). Camera Point, Pike's Peak, 16.vi.1956, + , JSS 21157, R. \& K. Dreisbach (MSUC). Idaho: Island Park, [44.424364, -111.371064], JSS 25099, Bernard Knapp (EMUS). Nez PerCe Co.: Lake Waha, [46.205942, -116.837015], 9.vi.1918, 9 , CNCD 26402, A.L. Melander

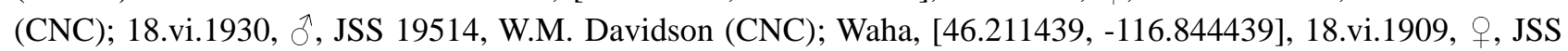
19501, (CNC); 30.v.1924, +, JSS 23778, A.L. Melander (USNM). LATAH Co.: Moscow Mt., [46.800972, 116.866093], 8.vi.1921, + , JSS 23776, 26.vi.1922, , , JSS 23777, A.L. Melander (USNM); Mountains Near 
Moscow, Latah County, [46.807258, -116.868969], 1.vi.1907, ๆ, CNCD 26403, (CNC); 17.vi.1918, §, JSS 19509, 26.vi.1920, đ, JSS 19506, 9.vii.1920, ㅇ, JSS 19505, A.L. Melander (CNC); vii.1910, , JSS 19510, 25.vi.1920, o, JSS 19516, R.C. Shannon (CNC). Savary, 29.iv.1916, , JSS 21329, (MCZ). New Mexico: Las Cruces, Dona Ana, [32.3, -106.7666667], + , CNCD 26423, F.M. Hull (CNC). LinCOLn Co., Sierra Blanca, [33.478065, 105.552907], 2957m, 10-26.vi.1979, Ĵ, JSS 18307, S. \& J. Peck (CNC). SAN MiguEL Co., Santa Fe National Forest, [35.705996, -105.545731], 27.v.1981, q, JSS 18346, B.J. Sinclair (CNC). SANDOVAL Co.: Jemez Springs, [35.771336, -106.690555], iv, + , CNCD 26422, (CNC). Utah: WASATCh Co.: Daniels Pass, 2 miles South, [40.280034, -111.223675], 2591m, 9.vii.1961, +, CNCD 26421, J.G. Chillcott (CNC). DusCHENE Co.: 2 miles West of Mirror Lake, [40.70363, -110.928511], 23.vi.1968, ô, CNCD 26438, B.V. Peterson (CNC). CACHE Co.: Card Canyon, [41.76236, -111.663482], 13.vi.1937, \&, CNCD 26420, A.E. Nye (CNC); Cowley Canyon, [41.772669, -111.60407], 13-27.v.1989, ô, JSS 24612, W.J. Hanson (EMUS); Tony Grove Lake, [41.893136, 111.641841], 1.vii.2010, CNCD 60037-60040, §, JSS 24615, M.M. Locke (CNC); West Hodges Canyon, [41.910305, -111.42277], 13-20.vi.1980, JSS 25096, (EMUS); Left Hand Fork, Blacksmith Fork Canyon, 24.v.2004, + , JSS 24617, Brammer (EMUS). RICH Co.: Logan Canyon Summit, [41.862735, -111.494404], 26.vi.-2.vii.1982, JSS 25098, (EMUS). Wyoming: Yellowstone NATIONAL PARK: Lewis Lake, [44.306126, 110.537673], 17.vii.1923, + , JSS 19500, A.L. Melander (CNC); 17.vii.1923, + , JSS 23774, A.L. Melander (USNM).

\section{Dasysyrphus pinastri (DeGeer)}

Figures: 15A-D, 18C, 21D

Synonyms and References:

Musca pinastri De Geer 1776: 113, Pl. 7 Fig. 1-7 (original description)

Syrphus lunulatus of authors nec. Meigen

Dasysyrphus pinastri (De Geer):

Vockeroth 1992: 70 (key and redescription)

Doczkal 1996: 40 (discussion and character chart)

Mutin \& Barkalov 1999: 398 (key)

Stubbs \& Falk 2002: 88 (key and discussion)

Reemer 2002: 14 (key and discussion)

van Veen 2004: 88 (key)

Barkalov 2007: 288 (key and redescription)

Bartsch et al. 2009: 199 (key and redescription)

Krpac et al. 2009: 105 (discussion)

Speight 2011: 71 (discussion)

Diagnosis: Abdominal maculae of tergites $3 \& 4$ slightly arcuate, uniform in thickness and do not cross abdominal margin (Figs 15A \& B); very similar in appearance to D. pauxillus (Fig. 14A), D. pacificus (Fig. 13A), D. nigricornis (Figs 11A \& B) and D. laticaudus (Fig. 8A), sternite 2 with dark macula (Fig. 18C), dark marking is fasciate in the other species. Male surstylus with posterolateral corner is much less prominent (Fig. 15D) than in other pauxillus group species (Figs 8C, 11D, 13D \& 14D).

Redescription:

Body Length: 8.4-10.4mm; Wing Length: 7.8-9.0mm

Head: Frons dark with light pollenose fascia (in males it runs along ventral edge of where eyes meet, in females it is $1 / 3$ the length between the antennae and ocelli) and dark pile; face light with dark vitta $1 / 4-1 / 3$ the width of the face, not reaching antennal socket, face with light pile; gena dark (sometimes slightly lighter posteroventrally) with light pile and usually some dark pile below eye; occiput dark, covered in light pollen, pile light; scape, pedicel and flagellomere dark, usually uniform in colour, flagellomere sometimes appears slightly lighter.

Thorax: Scutum dark, may appear shiny or metallic, pile light; scutellum light with darker anterolateral edges, dark pile with few light pile along anterior edge; wing cells $r_{1}$ and br usually with bare base (in br above spurious vein only), cell c sometimes with very small bare areas, cup with very small bare areas below vein CuP, bm densely microtrichose throughout (Fig. 15C); haltere light but can be slightly darkened in areas; femora $1 / 3-3 / 4$ dark basally, $1 / 4-2 / 3$ light apically, tibiae light, metatibia with dark band $1 / 4$ of the way from the apex, sometimes extending to apex, tarsi light, sometimes dark anteriorly. 


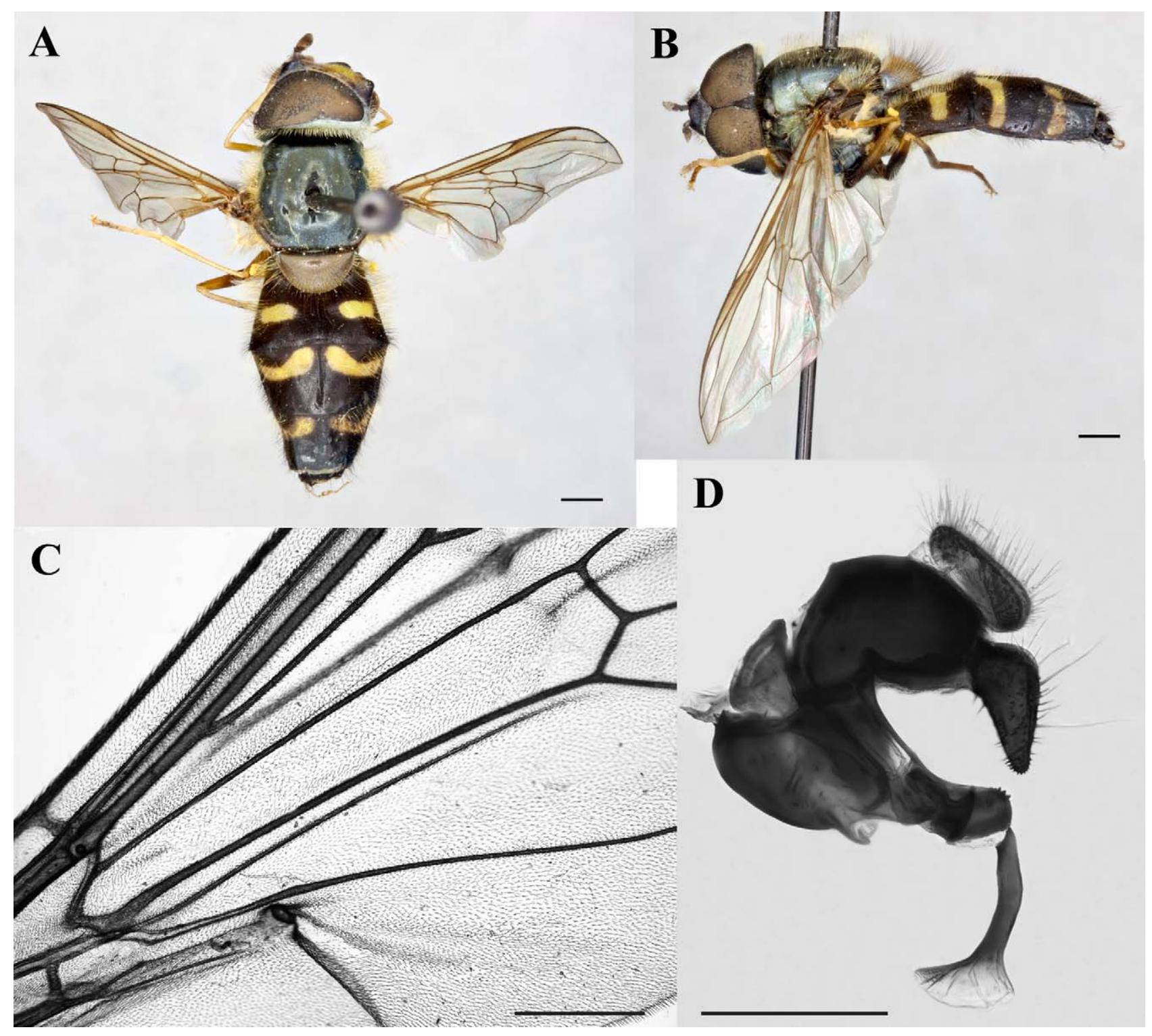

FIGURE 15. Dasysyrphus pinastri: A: male (JSS 18310) dorsal habitus (genitalia removed); B: male (JSS 18310) lateral habitus (genitalia removed); C: wing base (CNCD 26458); D: lateral view of male (JSS 18310) genitalia. Dorsal and lateral habitus scale bar $=1 \mathrm{~mm}$, genitalia and wing scale bar $=500 \mu \mathrm{m}$.

Abdomen: Maculae on tergite 2 large and oval, maculae on tergites $3 \& 4$ are oblique, anterior edge slightly concave and posterior edge straight, never meeting medially, maculae do not reach abdominal margin (Figs 15A \& B); sternite 2 with dark macula, sternites $3 \& 4$ light with dark fasciae.

Male Genitalia: Surstylus more or less triangular in shape in lateral view, flattened posteriorly and posterolateral corner is much less prominent than in other pauxillus group species, long pile on dorsal, laterodorsal and posterodorsal sides, row of spines on posteromedial edge; cercus oval with long pile over entire surface; gonostylus boot-shaped with projection on posterodorsal surface, projecting dorsally, pile on dorsal surface; basiphallus elongate, basally bent at a slightly more than 90 degree angle towards dorsum, apical end curved ventrally and partly membranous dorsally, with spines on posterodorsal side; distiphallus elongate, apical end flared out into horn, which is mostly sclerotized but membranous at apex, with few setulae dorsally, basally it is curved towards dorsum and not greatly enlarged at bend (Fig. 15D).

Intraspecific variation: Gena is dark but in some specimens can be slightly lighter posteroventrally; wing cells $\mathrm{r}_{1}$ and br usually with bare base, cell c sometimes with very small bare areas.

Etymology: From the Latin pinus, meaning pine and -aster, a diminutive suffix meaning little.

Distribution: Greenland and Europe (Fig. 21D). 
Ecology: Collected from May to July. One specimen was collected from an elevation of 2200m.

Discussion: Within the Nearctic, D. pinastri is only found in Greenland. It is found throughout the Palaearctic from the United Kingdom to Scandinavia, south to Italy. Due to its similar habitus to other species in the Palaearctic there has been widespread confusion about this species and its concept (Doczkal 1996; Reemer 2002; Speight 2011). The main reason for such confusion is that the syntypes of this species are lost (Thompson \& Pont 1994). They were not in the De Geer collection when it was donated to the Naturhistoriska Riksmuseet (The Swedish Museum of Natural History) in Stockholm, Sweden, in 1834 (Thompson \& Nielsen 1984; Thompson \& Pont 1994). Thompson \& Pont (1994) designated the specimen illustrated by De Geer (1776, Pl. 7 Fig. 1) as the lectotype for pinastri. Since this lectotype has been missing for over 175 years and because this has lead to confusion about the species concept, a neotype is designated here to bring stability of the name pinastri. This designation will create a solid concept for this species, allowing for better reconciliation with closely related species. Characters are consistent with De Geer's (1776) vague description of the adult and with Doczkal's (1996) characters used to distinguish it from pauxillus s.l. and lenensis. De Geer (1776) does not state the locality/ localities of his specimens, however, as he was from Sweden and reared these flies from larvae it is likely that he collected them close to home. Therefore the Neotype chosen is from Sweden. The Neotype is a male from Holmsund Vb., Sweden, collected on 1.vii.1967 by W.J. Boyes. It is deposited in the CNC and databased with the number Jeff Skevington Specimen 18310. The genitalia have been dissected and a leg was removed to sequence the $5^{\prime}$ region of COI.

Type Material: "Holmsund/ Vb., SWEDEN/ 1.VII.1967/ J.W. Boyes", "Boyes Cytolog./ Coll. \# WS101/ To remain/ in C.N.C.", "J. Skevington/ Specimen \#/ 18310", "Dasysyrphus/ pinastri DeG./ Det. J.R. Vockeroth", "NEOTYPE/ Musca/ pinastri/ De Geer", "designated by/ Locke \&/ Skevington/ 2013”; 今ึ; right meso- and metalegs missing; genitalia dissected, in vial on specimen pin; deposited in the Canadian National Collection of Insects, Arachnids and Nematodes (CNC), Ottawa, Ontario, Canada.

Material Examined:

Denmark: Fellins Skov, 22.v.1967, đ̊ CNCD 26450, E. Torp (CNC). Hytter Kobbel, Sdrj., 24.vi.1967, ㅇ, CNCD 26456, E. Torp (CNC). Lillebro, Loso, 25.vi.1966, q, CNCD 26457, E. Torp (CNC). North Denmark Region: Bangsbo Skole, [57.424683, 10.519762], 2.vi.1967, ô, CNCD 26448, E. Torp (CNC). South Denmark: Draved Skov, [55.016651, 8.983375], 10.v.1966, ô, CNCD 26447, क , CNCD 26455, E. Torp (CNC). Greenland: Sondrestom Air Base, [67.010556, -50.709167], 30.viii.1952, $\odot$, CNCD 26459, W.J. Brown (CNC). Italy: Piedmont: Celle de Bellino, [44.579948, 7.007859], 11-12.vii.1974, intersex, JSS 18309, W. Baker (CNC). Poland: Szklarska Porpba, distr. Telenia Gora Taka, 9.vii.1958, ô, CNCD 26449, R. Trojan (CNC). Sweden: Västerbottens Län: Holmsund, [63.705557, 20.37888], 1.vii.1967, q, CNCD 26454,3.vii.1967, ô, JSS 18311, q, CNCD 26453, J.W. Boyes (CNC). Switzerland: Valais: Zermatt, Rifolalb, 2200m, 23.vi.1959, + , CNCD 26458, F. Keiser (CNC). Jura: Delemont, [47.365206, 7.343584], 17-24.v.1969, §ิ, JSS 18308, Herting \& Wood (CNC). United Kingdom: England: Bristol, Westbury, [51.502888, -2.601311], 18.v.1959, Ô, CNCD 26446, M. Ackland (CNC). Staffordshire, Newcastle-under-Lyme, [53.008764, -2.231836], 6.vi.1960, क, CNCD 26452, J.R. Vockeroth (CNC). Cumbria, Lakes District National Park, Blea Tarn, [54.429748, -3.092892], 5.vi.1941, 20, CNCD 26444, 26445, G.E. Shewell (CNC).

\section{Dasysyrphus richardi Locke \& Skevington sp. nov.}

Figures: 16A-C, 20C

Diagnosis: Similar in appearance to lotus (Figs 10A \& B), with maculae on tergites $3 \& 4$ oblique, uniform in thickness, meeting medially and not crossing the abdominal margin (Figs 16A \& C). Dasysyrphus richardi has a dark vitta separating the gena from the face (Figs 16A \& C) and the wing extensively bare basally (Fig. 16B), where as lotus is continuously light from face to gena (Fig. 10B) and the wing is more microtrichose (Fig. 10C).

Description:

Body Length: 7.2-8.0mm; Wing Length: 7.2-7.5mm

Head: Frons dark with light pollenose fascia (in female it is $1 / 2$ the length between the antennae and ocelli and is continuous, sometimes notched medially) and dark pile; face light with dark vitta medially, that is $<1 / 4$ the width of the face, not reaching antennal socket, face with dark pile; gena light with light pile and sometimes interspersed 
with dark pile, separated from face by dark vitta (Figs 16A \& C); occiput dark, covered in light pollen, pile light with some dark pile dorsally; scape and pedicel dark, flagellomere dark, lighter at base.

Thorax: Scutum dark, may appear shiny or metallic, with two faint pollenose vittae medially, extending just past the transverse suture, pile light; scutellum light with darker lateral edges, light pile with some dark pile posteriorly; wing cells br and bm entirely bare, cell c bare at base and along $\mathrm{Sc}, \mathrm{r}_{1}$ bare at base and cup bare at base and along vein $\mathrm{CuP}$ and posterior edge, $\mathrm{r}_{2+3}, \mathrm{r}_{4+5}, \mathrm{dm}$, cua ${ }_{1}$ and anal lobe with bare areas at base (Fig. 16B); haltere light; pro- and mesofemur $1 / 3-1 / 2$ dark basally, $1 / 2-2 / 3$ light apically, metafemur $2 / 3-3 / 4$ dark basally, $1 / 4-1 / 3$ light apically, tibiae light, metatibia slightly darkened medially, tarsi light.

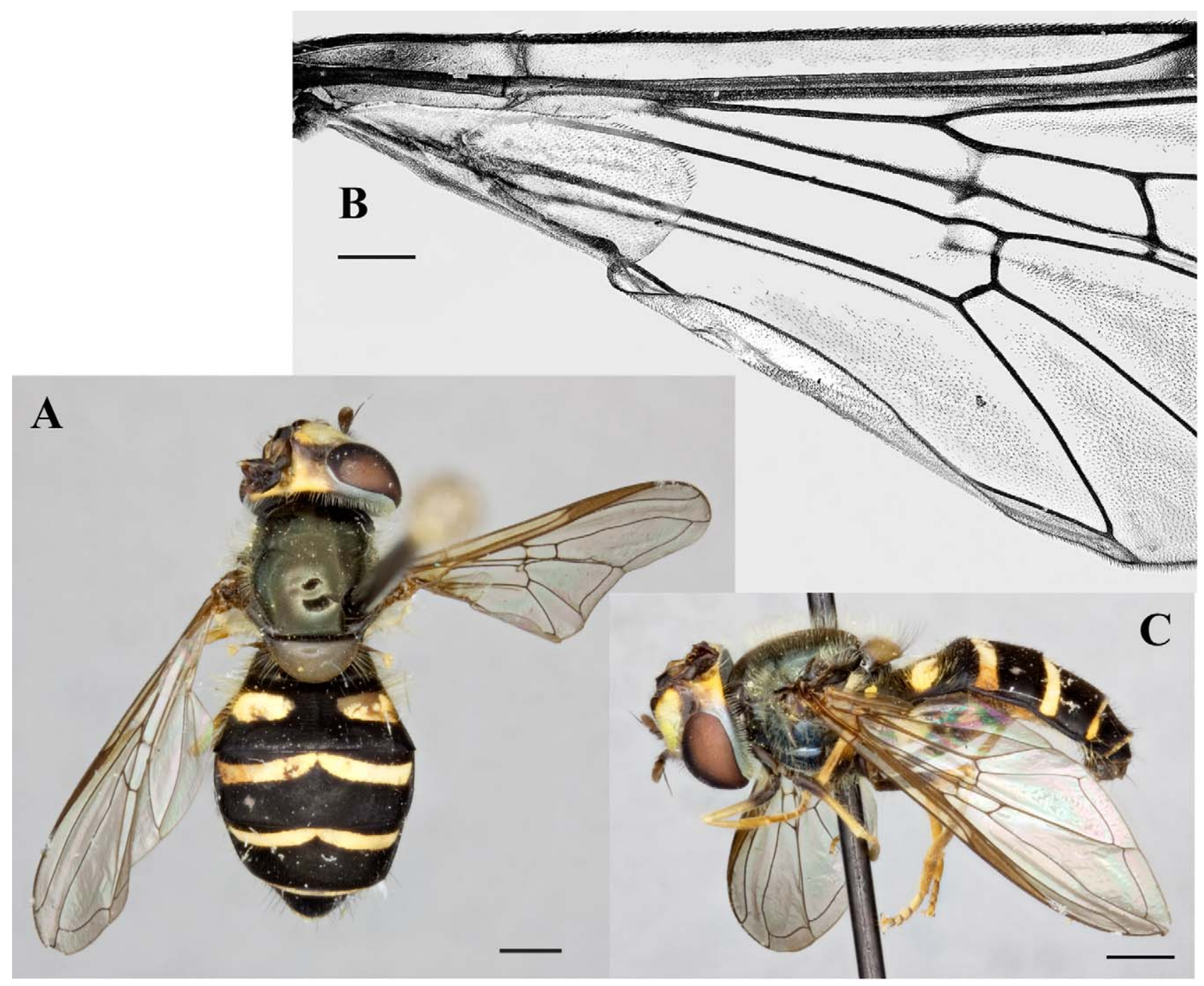

FIGURE 16. Dasysyrphus richardi: A: female (USNM ENT 00258072) dorsal habitus; B: wing base (USNM ENT 00258072); C: female (USNM ENT 00258072) lateral habitus. Dorsal and lateral habitus scale bar $=1 \mathrm{~mm}$, wing scale bar $=500 \mu \mathrm{m}$.

Abdomen: Maculae on tergite 2 large, oval to triangular, slightly narrowed on medial end, $1 / 3-<1 / 2$ width of tergite, maculae on tergites $3 \& 4$ are straight and oblique, meeting medially, maculae do not reach abdominal margin and are uniform in thickness (Figs 16A \& C); sternites light with dark fasciae of varying thickness.

Male Genitalia: Male unknown.

Intraspecific variation: Maculae on tergite 2 varying slightly in size and shape from $1 / 3-<1 / 2$ width of tergite and oval to slightly more triangular.

Etymology: This species is named after the systematist Dr. J. Richard Vockeroth, who recognized this as a unique species and labeled the specimens as so, but did not ever describe them.

Distribution: Southwestern USA (NM) (Fig. 20C)

Ecology: Two specimens have been collected in June in the southern Rocky Mountains. 
Discussion: Known from two female specimens only. They were collected during the same collecting event in New Mexico in 1977. DNA was not extracted from these specimens as our techniques to extract from 30 year-old specimens need some improvement so that an attempt to extract DNA will have as great a chance as possible of success. With only two known specimens in existence this is crucial. Unfortunately with no male specimens, genitalia characters were not available for study. However, because richardi shares such a similar habitus to lotus it is likely that they are of close relation. An effort to find more specimens should be undertaken to locate the male of this species and to have more material made available in order to ascertain the full breadth of its molecular and morphological variation.

Type Material: "New Mexico, Los Alamos/ Bandelier Nat. Mon./ June 1977/ W. Pippen \#D-18”, "USNM ENT 00258072", "HOLOTYPE/ Dasysyrphus/ richardi/ Locke \&/ Skevington"; + , deposited in the United States National Museum of Natural History, Washington, D.C (USNM).

Material Examined:

Paratype: United States of America: New Mexico: Los Alamos, Bandelier Nat. Mon., [35.783115, 106.25619], vi.1977,, , USNM ENT 258073, W. Pippin (USNM).

\section{Dasysyrphus venustus (Meigen)}

Figures: 17A-D, 22

Synonyms and References:

Scaeva arcuata Fallén: 1817: 42 (original description)

Dusek \& Laska 1969: 171 (name suppression proposal)

International Commission on Zoological Nomenclature 1972 1972: 9 (name suppression)

Syrphus venustus Meigen 1822: 299 (original description)

Syrphus lunulatus Meigen 1822: 299 (original description)

Syrphus reflectipennis Curran 1921: 157 (original description)

Metasyrphus reflectipennis (Curran):

Fluke 1933: 109 (key, redescription and transfer to Metasyrphus)

Metasyrphus venustus (Meigen):

Fluke 1933: 112 (key, redescription and transfer to Metasyrphus)

Dasysyrphus lunulatus (Meigen):

Enderlein 1938: 208 (transfer to Dasysyrphus)

Stone et al. 1965: 564 (catalogue and transfer back to Dasysyrphus)

Goeldlin de Tiefnau 1974: 208 (lectotype designation)

Syrphella lunulatus (Meigen):

Goffe 1944: 129 (transfer to Syrphella)

Syrphella venustus (Meigen):

Goffe 1944: 129 (transfer to Syrphella)

Dasysyrphus arcuatus (Fallén):

Stone et al. 1965: 563 (catalogue and transfer to Dasysyrphus)

Peck 1974: 128 (key)

Dasysyrphus reflectipennis (Curran):

Stone et al. 1965: 564 (catalogue and transfer to Dasysyrphus)

Dasysyrphus venustus (Meigen):

Dusek \& Laska 1967: 354 (transfer to Dasysyrphus?)

Goeldlin de Tiefnau 1974: 208 (lectotype designation)

Vockeroth 1986: 203 (discussion)

Peck 1988: 16 (catalogue)

Vockeroth 1992: 70 (key and redescription)

Mutin \& Barkalov 1999: 397 (key)

Stubbs \& Falk 2002: 88 (key and discussion)

van Veen 2004: 87 (key)

Barkalov 2007: 294 (key and redescription)

Bartsch et al. 2009: 202 (key and redescription)

Speight 2011: 72 (discussion)

Diagnosis: Abdominal maculae cross abdominal margin; maculae on tergite 2 large ( $>1 / 3$ width of tergite) ovalshaped; maculae on tergites $3 \& 4$ are transverse, constricted slightly medially, with medial edge swollen slightly 
(Figs 17A \& B). Similar to D. limatus however maculae on tergite 2 are always small in D. limatus (Fig. 9A), less than $1 / 4$ the width of the tergite, and are much larger in D. venustus, greater than $1 / 3$ the width of the tergite. Also often confused with species in $D$. intrudens complex, however, species in this complex have maculae that are arcuate, lunulate and/or greatly constricted medially.

Redescription:

Body Length: 7.9-11.2mm; Wing Length: 7.4-10.4mm

Head: Frons dark with light pollinose fascia (in males it runs along ventral edge of where eyes meet, in females it is $1 / 3-1 / 2$ the length between the antennae and ocelli and widely separated medially) and dark pile; face light with dark vitta $1 / 4-1 / 3$ the width of the face, usually reaching antennal socket, face with light to dark pile or combination of light and dark pile; gena dark with dark to light pile or a combination of light and dark pile; occiput dark, covered in light pollen, pile light; scape and pedicel light, flagellomere usually light basally and darker apically, sometimes mostly dark.

Thorax: Scutum dark, may appear shiny or metallic, pile light; scutellum light with darker anterolateral edges, light pile some with few dark pile along posterior edge; wings can range from being entirely densely microtrichose to having wing cells $r_{1}$, br and bm bare base (in br above spurious vein only) and cell cup with small bare areas below vein $\mathrm{CuP}$ (Fig. 17C); haltere light; pro- and mesofemora 1/4-1/2 dark basially, 1/2-3/4 light apically, metafemur $2 / 3$ dark basially, $1 / 3$ light apically, tibiae light, metatibia with dark band $1 / 4$ of the way from the apex, tarsi light, metatarsi dark anteriorly.

Abdomen: Maculae on tergite 2 large and oval with anterolateral edge extending to edge of abdomen, maculae on tergites $3 \& 4$ are transverse, constricted slightly medially, with medial edge swollen slightly, almost never meeting medially, maculae cross abdominal margin (Figs 17A \& B); sternite 2 either all light or with dark fascia (usually distinct, sometimes faint), sternites $3 \& 4$ light with dark fasciae.

Male Genitalia: Surstylus more or less triangular in shape in lateral view, flattened anteroposteriorly with long pile on posterior side and spines on anteroventral side, similar to D. intrudens complex (Fig. 7F) and D. limatus (Fig. 9D); cercus oval with long pile over entire surface; gonostylus is pointed ventrally, dorsally flattened at base then it expands dorsally at apex, oblique ridge near apex, with ends of ridge projecting into points; pile on dorsal surface; basiphallus is basally bent at about a 90 degree angle towards dorsum, apical end enlarged and curved ventrally, fully sclerotized all the way around with no pile or spines; distiphallus long with no enlarged area basally, apical end flared out into horn with the dorsal side flattened slightly, which is mostly sclerotized but membranous at apex with setulae dorsally (Fig. 17D).

Intraspecific variation: The abdominal maculae of the male are sometimes more arcuate and with a more swollen medial edge of maculae. Wings cells $\mathrm{r}_{1}, \mathrm{br}$, bm, and cup range from being entirely microtrichose to having bare areas.

Etymology: From the Latin venustus, meaning charming, lovely, beautiful, graceful.

Distribution: Canada (AB, BC, MB, NT, NS, ON, QC, YT) and US (AK, ID, ME, MI, NH, NM, NC, PA, UT, VT, VA, WV), also widespread over Europe and Asia (Fig. 22).

Ecology: Collected from May-August, but more frequently in May and June. Collected at elevations from 260-2957m. Habitats listed on labels include "bog", "fell-field tundra", "Mh/Be forest" (mixed hardwood/beech), "pine forest", "boreal mixed wood forest", "black spruce forest $(25 \%)$ with moss", "Picea-Betula forest". Specimens have been collected from hilltops.

Discussion: The species concept for $D$. venustus has been uncertain for quite some time now, especially in the Nearctic. Fluke's (1933) concept was much like that of this one, distinguishing venustus as having markings that are more straight than specimens in the intrudens complex, which is treated by Fluke as laticaudatus, amalopis (in part) and osburni. Vockeroth (1986) synonymized the intrudens complex under venustus as he believed it was simply a variable species. While abdominal maculae vary greatly, many of the other characters are similar, including the male genitalia.

Dasysyrphus osburni, intrudens, disgregus and laticaudatus were all considered synonyms of venustus by Vockeroth (1992), however these four names fall within what we recognize as the intrudens complex.

The only specimen of D. reflectipennis is that of the holotype (located at the CNC). It is a female with its abdomen broken and glued to a point below the specimen. It was treated as a unique species by Fluke (1933) and by Vockeroth (1986). However, at the time, Vockeroth believed that reflectipennis was a specimen of venustus with aberrant markings. He stated that he was not ready to treat it as a synonym until other specimens were found. Other 
specimens were not found, but in 1992 he synonymized reflectipennis with venustus. The abdominal maculae of tergite 3 are like that of venustus, however they narrowly meet medially. We have seen no other specimens where the maculae meet, but since the specimen of reflectipennis looks like that of venustus in every other way, it is logical to conclude that Vockeroth was correct in saying that the specimen of reflectipennis is actually a specimen of venustus with aberrant markings.

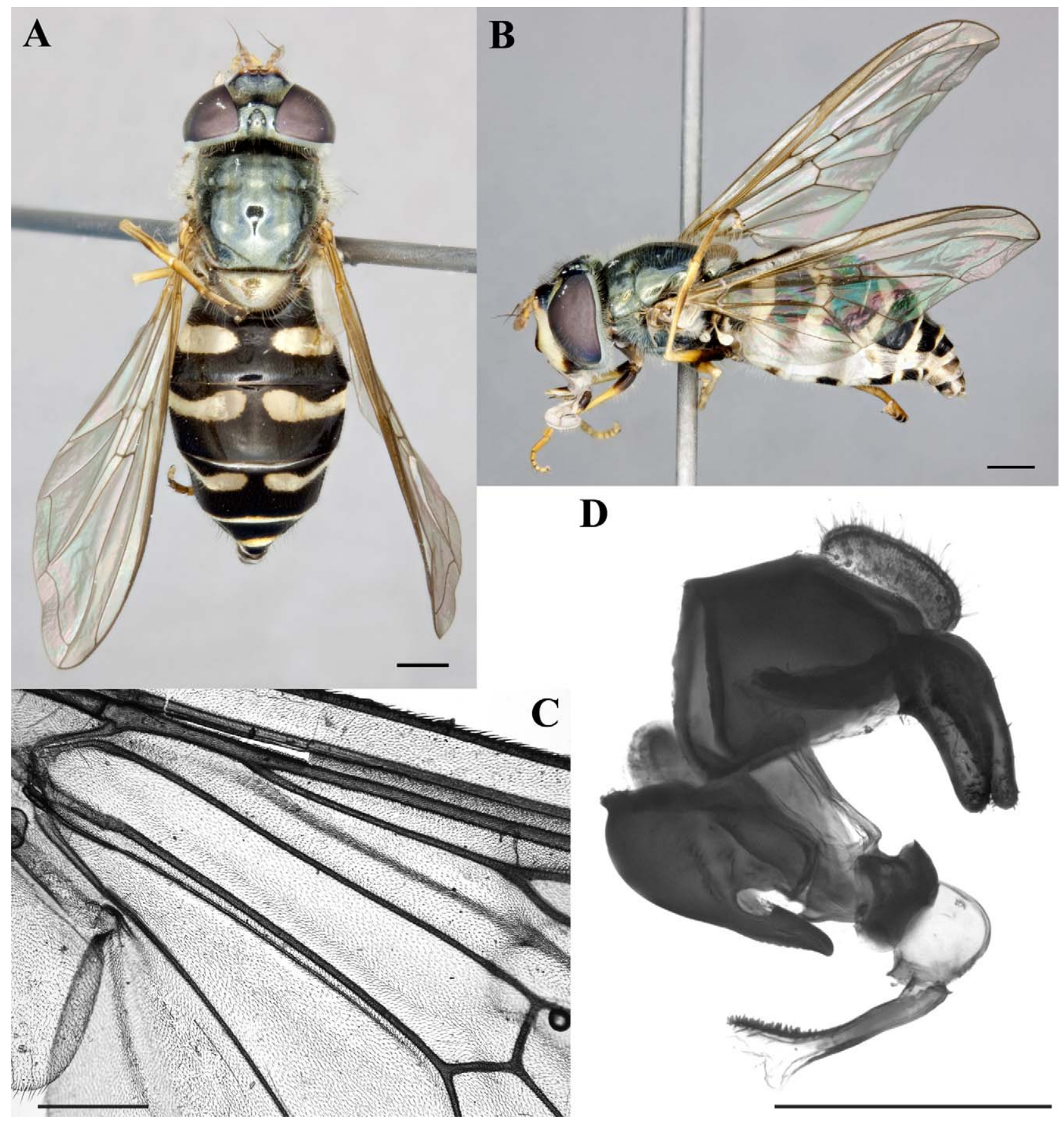

FIGURE 17. Dasysyrphus venustus: A: female (CNCD 30888) dorsal habitus; B: female lateral (CNCD 30888) habitus; C: wing base (CNCD 5458); D: lateral view of male (CNCD 14567) genitalia. Dorsal and lateral habitus scale bar $=1 \mathrm{~mm}$, genitalia and wing scale bar $=500 \mu \mathrm{m}$.

There are five specimens that appear to be morphologically identical and sympatric with venustus but differ from it in their COI sequences (CNCD 5458, 30889, 30890, 30902, JSS 20982; Fig. 4). It is possible that this is a cryptic species but until more specimens are available to provide more precise geographical and ecological evidence and/or morphological and DNA characters they are retained under the name venustus. 


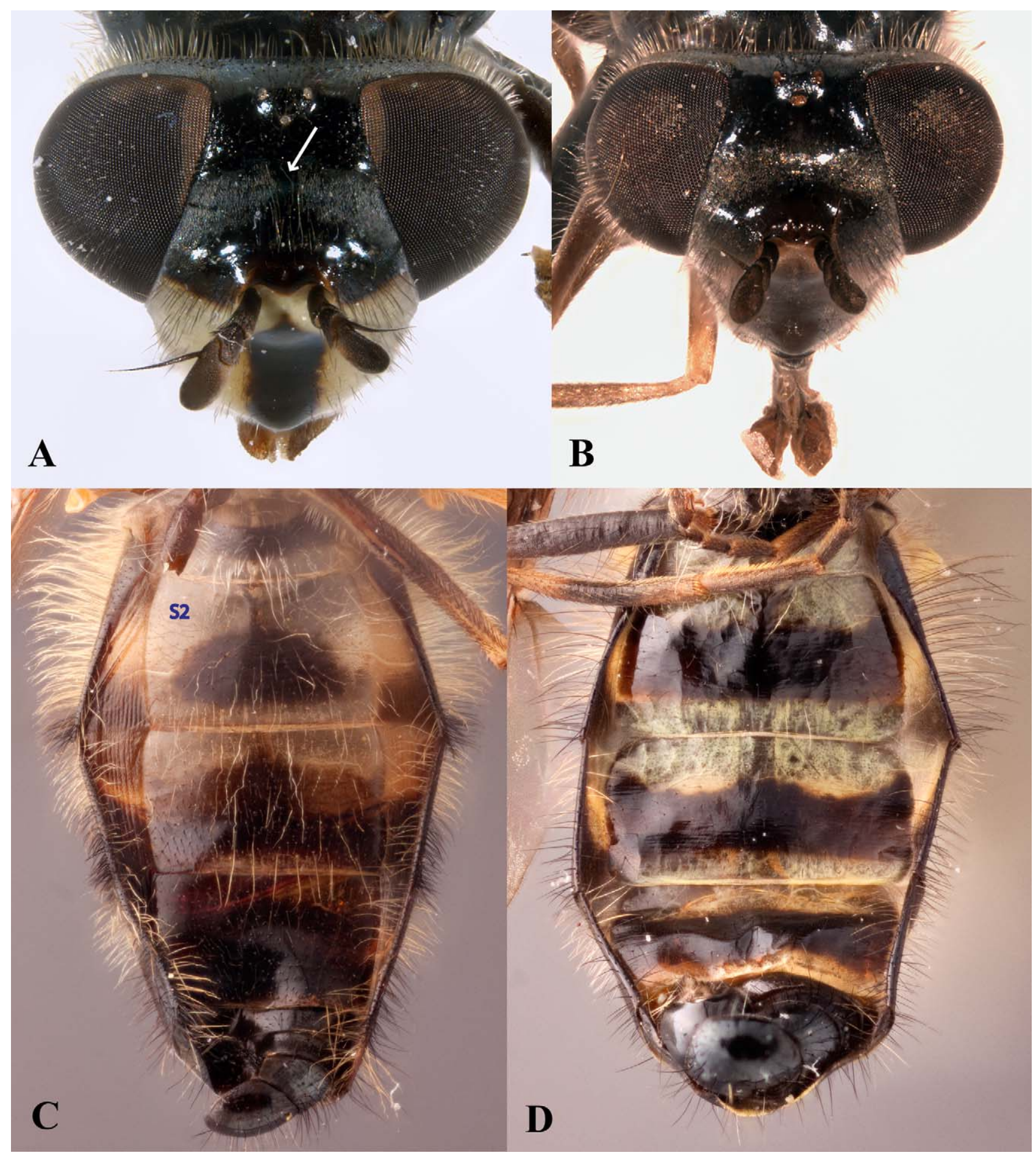

FIGURE 18. A: female Dasysyrphus pauxillus (JSS 24618) head showing interrupted pubescent band on frons (white arrow); B: female D. nigricornis (CNCD 13739) showing uninterrupted pubescent band on frons; C: ventral view of male D. pinastri (JSS 18308; genitalia removed) showing oval macula on sternite 2 (S2); D: ventral view of male D. pauxillus (CNCD 60039) showing fascia on sternite 2 .

Type Material: From Germany, deposited in the Muséum National d'Histoire Naturelle (The National Museum of Natural History), Paris, France (Pape \& Thompson 2010b). (not examined; requested but not obtained)

Material Examined:

Canada: Alberta: Itaska Audubon Reserve, Pigeon Lake, [53, -114], 18.v.2008, §̂, JSS 21073, ๆ, JSS 21074, F.A.H. Sperling (FAHS). Drayton, [53.220865, -114.978236], 29.vi.1988, , , UASM\# 149016, E.H. Strickland (UASM). Edmonton, Division No.11, [53.540941, -113.493698], 5.vi.1948, ㅇ, CNCD 14537, J.R. Vockeroth 
(CNC); 20.v.1923, , CNCD 14538, E.H. Strickland (CNC); 12.v.1924, ㅇ, JSS 19540-19545, 19551-19554,

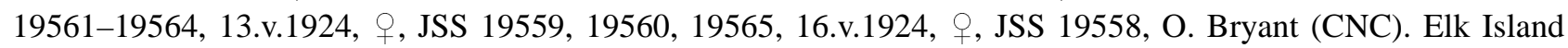
National Park, [53.604578, -112.859291], 19.v.1981, +, CNCD 14540, J.E. O’Hara (CNC). Bilby, Division No. 13, [53.698357, -114.10198], 1.vi.1924, + , JSS 19546, O. Bryant (CNC). British Columbia: CenTRAL KoOTENAY

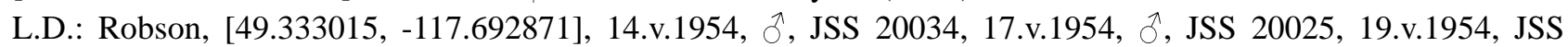

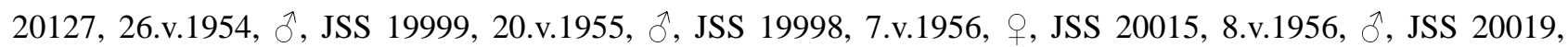

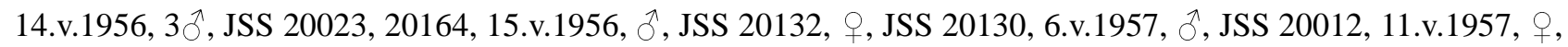
JSS 20002, 21.v.1957, + , JSS 20095, 7.vi.1965, + , JSS 20122, 25.v.1965, + , JSS 20092, H.R. Foxlee (UBCZ); 14.v.1947, ô, CNCD 14510, 11.v.1948, क, CNCD 14242, 2.vi.1948, + , CNCD 14303, H.R. Foxlee (CNC). Miracle Beach, Near Oyster Bay, [49.854574, -125.098409], 13.vi.1955,, , CNCD 14314, J.R. McGillis (CNC). Salmon Arm, [50.703923, -119.273924], 2.v.1930, $q$, JSS 20159, Hugh B. Leech (UBCZ). 32 miles South West of Terrace, [54.194076, -129.140296], 30.5m, 8.vi.1960, §̂, CNCD 14509, G.E. Shewell (CNC); 11.vi.1960, 2 , CNCD 14217, 14341, B. Heming (CNC). Spring Creek, Terrace, [54.539511, -128.618192], 1.vi.1960, +, CNCD 14231, C.H. Mann (CNC). Kitsumkalum Lake, 20 Miles North of Terrace, [54.762473, -128.770968], 16.vi.1960, , , CNCD 14227, J.G. Chillcott (CNC). Kispiox, [55.348319, -127.687346], 24.v.1958, ठૈ, JSS 20152, J. Foster (UBCZ). Atlin, [59.5775, -133.69236], 670.56m, 9.vi.1955, 2ㅇ, CNCD 14251, 14252, 20.vi.1955, , CNCD 14223, 6.vii.1955, + , CNCD 14284, B.A. Gibbard (CNC); 20.vi.1955, § , CNCD 14360, 7.vii.1955, + , CNCD 14289, H.J. Huckel (CNC). Blanchard R. Haines Rd., [11.vi.1979, +, JSS 20146, G.J. Spencer (UBCZ). Kiskatinaw Public Campground, Alaska Highway DC-20 (31.4km), [26.vi.1978, + , JSS 23719, Paul H. Arnaud, Jr. (CAS). Manitoba: Aweme, [49.708529, -99.602758], 19.v.1926, , CNCD 14550, 27.v.1925, ㅇ, CNCD 14554, 1.vii.1966,, , CNCD 14555, R.D. Bird (CNC); 20.vi.1925,, , CNCD 14551, R.M. White (CNC). 5 miles South West of Shilo, [49.763964, -99.717403], 28.v.1958,, , CNCD 14552, J.F. McAlpine (CNC); 5.vi.1958, $\odot$, CNCD 14553, C.D.F. Miller (CNC). Erickson, [50.498283, -99.9078], 17.vi.1983,, , JSS 20195, D.H. Pengelly (JBWM). ChURCHILL: Burn site N[orth] of Twin lakes, [58.61861111, -93.82888889], 4.vii.2007, क, CNCD 9495, 5.vii.2007,, , CNCD 9582, J. Skevington (CNC); Bus Stop, [7.viii.2007, $\odot$, JSS 24644, P. Kevan (CNC). New Brunswick: CHARLOTTE Co.: Chamcook, [45.126407, -67.071693], 28.vi.1965, 3ㅇ, CNCD 14817-14819, G.E. Shewell (CNC). NORTHUMBERLAND Co.: Doaktown, [46.556585, -66.126203], 6.vii.1971, + , CNCD 14820, B.V. Peterson (CNC). Kent Co.: Kouchibouguac National Park, [46.819201, -64.96788], 19.vi.1978, 2 \%, CNCD 14815, 14816, S.J. Miller (CNC). Snow Cap Park, Hwy 17, [5.vii.1971, + , CNCD 14821, B.V. Peterson (CNC). Northwest Territories: Jean-Marie Creek, 42 Miles South West of Fort Simpson, [61.372555, -122.224182], 13.vi.1972,, , CNCD 14047, B.V. Peterson (CNC). Coppermine, [62.562732, -115.092764], 30.vi.1951,, , CNCD 14058, S.D. Hicks (CNC). Wrigley, Mackenzie, [63.209367, -123.34594], 15.vi.1969, क, CNCD 14056, G.E. Shewell (CNC). Nova Scotia: KINGS Co.: [45.017428, -64.610757], 22.vi.1983, + , CNCD 14779, 23.vi.1983, + , CNCD 14778, J.R. Vockeroth (CNC). COLCHESTER Co., Truro, [45.364959, -63.279846], 7.vii.1919, §ิ, CNCD 14769, (CNC). ViCTORIA Co., Baddeck, Cape Breton Island, [46.10001, -60.753507], 15.vi.1931, 9 , CNCD 14780, G. Fairchild (CNC); Dingwall, [46.896638, -60.469402], 23.vi.1983, +, CNCD 14777, J.R. Vockeroth (CNC); INVERNESS Co., Cape Breton Highlands National Park: French Lake, [46.728452, -60.86483], 2430.vi.1984, 2 , CNCD 14774, 14775, H.J. Teskey (CNC); North Mtn. Bog, [46.805111, -60.688224], 400m, 7.vi.1984, 2ð, CNCD 14759, 14760, B.E. Cooper (CNC); Mackenzie Mountain, [46.773977, -60.818772], 400m,

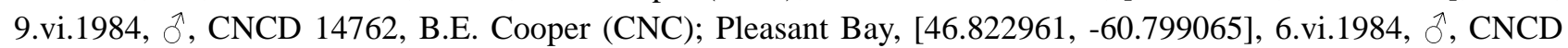

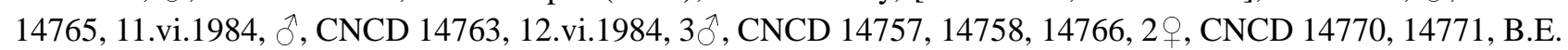
Cooper (CNC); 25-29.vi.1984, , CNCD 14776, H.J. Teskey (CNC). Ontario: Crawford, [44.253882, 80.929867], 7-16.vi.1998, 4ㅇ, ROMEnt Spec. No. 57872, 57887-57889, 8-17.vii.1998, ROMEnt Spec. No. 74031, A. Sugar (ROME). Cranberry Lake, Runtz property, [44.44111111, -76.29055556], 18-24.v.2007, 2ᄋ, CNCD 30889, 30890, J. Skevington, H. Douglas, D. Runtz (CNC). LEEDS Co.: Chaffeys Lock, [44.579098, 76.319816], 28.v.1972, +, CNCD 14593, P. Ward (CNC); SIMCOE Co.: Orillia, [44.609505, -79.42068], 26.v.1913, +, CNCD 15386, 30.v.1921, +, CNCD 14595, 7.vi.1925, +, CNCD 14594, C.H. Curran (CNC); Midland, [44.752113, -79.887253], 26.v.1959, क, CNCD 14600, J.G. Chillcott (CNC). Griffith, 7 miles East, [45.243279, 77.031193], 22.v.1982, § , CNCD 14567, B.E. Cooper (CNC). Stittsville, [45.263479, -75.925163], 24.vi.1963, $q$, CNCD 14598, W.R.M. Mason (CNC). Nepean, 24 Gervin Street, [45.31694444, -75.72], 28.v.2006 4.vi.2006, CNCD 30888, J.E. O'Hara (CNC). Mer Bleu, 5 Miles East of Ottawa, [45.40331, -75.5083], 31.v.1923,, , CNCD 14579, C.H. Curran (CNC); 5.vi.1966, 2 , CNCD 14585, 14586, 13.vi.1966, , CNCD 14587, 15.vi.1966, + , 
CNCD 14588, 17.vi.1966, 9 , CNCD 14589, 19.vi.1966, 2 9 , CNCD 14590, 1.vii.1966, ㅇ, CNCD 14592, D.D. Munroe (CNC). Ottawa, [45.411604, -75.688669], 29.v.1925, + , CNCD 14571, C.H. Curran (CNC). Waubamick, Parry Sound District, [45.446658, -80.017278], 14.vi.1915, 2q, JSS 19533, 19534, E.S. Parish (CNC). Dirleton, [45.494944, -76.142874], 29.iv.1968, +, CNCD 14599, J.E.H. Martin (CNC). AlgONQuin ProvinCial Park: Florence Lake [45.44371, -78.49012], 13.v.2007 29.v.2007, Ô, JSS 21385, E. Proctor (CNC); Cecil Lake, [45.4511, -78.4956], 17.v.2007 29.v.2007, §̃, JSS 21371, E. Proctor (CNC); 2 km E of Pondweed Lake, [45.4654, 78.4298], 16-28.v.2007, 20, JSS 21394, 21397, E. Proctor (CNC); Algonquin Park, [46, -78.08333333], $12-$ 19.vi.2003, ㅇ, ROMEnt Spec. No. 98532, 13.-20.vi.2003, 7ㅇ, ROMEnt Spec. No. 98522-98525, 98535, 98536, 98540, 17-24.vi.2003, +, ROMEnt Spec. No. 98541, 18-25.vi.2003, 3 , ROMEnt Spec. No. 98526, 98527, 98528, 98533, 20-27.vi.2003, 2 + , ROMEnt Spec. No. 98530, 98531, 10.vii.2003 17.vii.2003, , ROMEnt Spec. No. 98534, Mark Vanderwel (ROME). Atikokan, 14 miles East on Hwy 11, [48.723518, -91.313476], 3.vii.1978 4.vii.1948, $q$, CNCD 14582, H.J. Teskey (CNC). Iroquois Falls, [48.761811, -80.685262], 20.vi.1987, + , JSS 20773, J.R. Vockeroth (CNC). LowBush, Lake Abitibi, [48.91608, -80.139852], 6.vi.1925, ô, BOC 34653, 7.vi.1925, 2q, ROMEnt Spec. No. 115126, 115127, 13.vi.1925, 2q, ROMEnt Spec. No. 115128, 115130, 16.vi.1925, , ROMEnt Spec. No. 115131, 17.vi.1925, o, ROMEnt Spec. No. 115132, 23.vi.1925, $\circ$, ROMEnt Spec. No. 115133, 1.vii.1925, 4우, BOC 34649-34652, 14.vii.1925, ㅇ, BOC 34654, 18.vii.1925, 4우, BOC 3465534657, ROMEnt Spec. No. 115129, N.K. Bigelow (ROME); 9.vi.1925, + , CNCD 14572, 15.vi.1925, ㅇ, CNCD 14573, 16.vi.1925, 2 , CNCD 14574-14576, 14.vii.1925, \&, CNCD 14578, N.K. Bigelow (CNC); 1.vii.1925, + , UASM\# 149015, N.K. Bigelow (UASM); 1.vii.1925, +, JSS 21349, 14.vii.1925, + , JSS 21350, N.K. Bigelow (MCZ). Macdiarnid, Lake Nipigon, [49.438216, -88.12695], 7.vi.1921, q, BOC 34659, 24.vi.1923, 9, BOC 34660, N.K. Bigelow (ROME). Quebec: Covey Hill, Le Haut-Saint-Laurent, [45.019681, -73.745746], 20.vi.1924, + , CNCD 14755, G.S. Walley (CNC). Aylmer, [45.400224, -75.817137], 28.v.1923, §ึ, CNCD 14653, C.H. Curran (CNC). Ste. Anne de Bellevue, [45.406417, -73.950944], 12.v.1965, , LEM 8806, 1.vi.1966, $q$, LEM 8804, W. Boyle (LEMQ); 13.v.1965, †, LEM 8807, G. Jamieson (LEMQ); 15.v.1967, §, LEM 8805, A. Campbell (LEMQ). Abbotsford, [45.437637, -72.887923], vii.1935, +, CNCD 14711, G.E. Shewell (CNC);25.vi.1937, + , CNCD 14725, G. Shewell (CNC); 14.vi.1972, ㅇ, CNCD 14689, D.M. Wood (CNC). VAUdREuIL Co.: Mount Rigaud, [45.46638889, -74.32638889], 19.v.2004, §̂, CNCD 68, J. Skevington, L. Bartels, E. St. Louis, J. King (CNC); 24.v.2007, CNCD 8656, 8658, 8675, J. Skevington, A. Bailie, R. Farmahin, A. Kealey, S. Kelso, J. King (CNC). Les Collines-DES-L'OutAouAIS: Summit of King Mountain, Old Chelsea, [45.498058,

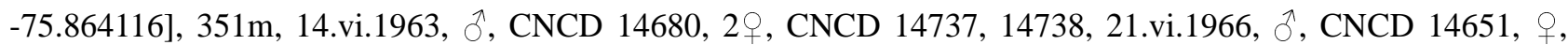

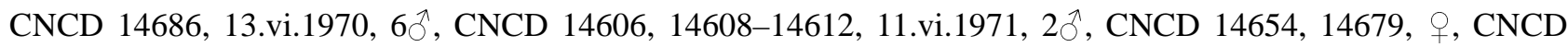
14736, 16.vi.1971, ô, CNCD 14671, 12.vi.1980, o, CNCD 14693, J.R. Vockeroth (CNC); 9.vi.1971, ô, CNCD 14681, D.M. Wood (CNC); Champlain Lookout, Gatineau Park, [45.508314, -75.913273], 335m, 1.vi.1965, ô, CNCD 14672, J.R. Vockeroth (CNC). Montreal Area, Communaute-Urbaine-de-Montreal, [45.526155, 73.702807], 6.vi.1964, 2 + , CNCD 14692, 14694, J.W. Boyes (CNC). Mont Saint-Hilaire, La Vallee-du-Richelieu, [45.552948, -73.155276], 411m, 11.vi.1967, ô, CNCD 14675, J.W. Boyes (CNC). Lac-Megantic, Le Granit, [45.57781, -70.884105], 18.vi.1923, ô, CNCD 14646, 20.vi.1923, + , CNCD 14753, C.H. Curran (CNC); 30.v.1971, O, CNCD 14667, D.M. Wood (CNC). Duncan Lake, near Rupert, [45.68138889, -76.05027778], 21.vi.1969,, , CNCD 14745, J.F. McAlpine (CNC); 19.v.1987, §, JSS 20767, D.M. Wood (CNC). Lac Cloutier, [46.184459, -73.64769], 30.v.1987 7.vii.1987, +, LEM 13620, (LEMQ). Schefferville, Iron Arm Fern, [54.805276, -66.805274], 28.vi.1990, , LEM 13928, 3-4.vii.1990, क, LEM 13459, P. McElligott (LEMQ). Great Whale

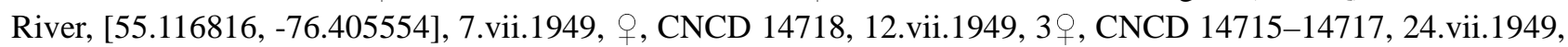
, CNCD 14724, 25.vii.1949, , CNCD 14714, 31.vii.1949, , CNCD 14719, J.R. Vockeroth (CNC). Indian House Lake, [56.328482, -64.720845], 8.vii.1954, , CNCD 14721, 10.vii.1954, §̊, CNCD 14683, 17.vii.1954, ㅇ, CNCD 14722, W.R. Richards (CNC). Kuujjuaq (Fort Chimo), [58.100076, -68.406179], 29.v.1948, ô, CNCD 14684, H.N. Smith (CNC); 14.vii.1948, , CNCD 14712, 28.vii.1948, , CNCD 14713, R.H. MacLeod (CNC). Saskatchewan: Great Deer, [52.580321, -107.056629], 21.v.1949, +, CNCD 14547, J.R. Vockeroth (CNC). Nipawin, Division No.14, [53.365608, -104.011519], 2.vi.1948, + , CNCD 14548, J.R. Vockeroth (CNC). Yukon Territory: Otter Lake, [62.486817, -130.4166667], 1219m, 17.vii.1960, + , CNCD 13966, J.E.H. Martin (CNC). Sheldon Lake, [62.616763, -131.266603], 1067m, 3.vii.1960, +, CNCD 13967, 7.vii.1960, +, CNCD 13968, J.E.H. Martin (CNC); 3.vii.1960,, , CNCD 13976, 7.vii.1960, 2 , CNCD 13974, 13975, E.W. Rockburne (CNC). La Force Lake, [62.683333, -132.333333], 1006m, 28.vi.1960, , CNCD 13955, E.W. Rockburne (CNC); 
7.vii.1960, 9 , CNCD 13949, J.E.H. Martin (CNC). DEMPSTER HighwAY: Mile 40, [64.448494, -138.223783], $1-$ 6.vii.1973, ô, CNCD 14029, G. \& D.M. Wood (CNC); Engineer Cr., km 152 [65.070828, -138.2399], 30.vi.1982, q, JSS 20140, S.G. Cannings, L. Vasington, R.A. Moore (UBCZ); km 416 [66.644581, -136.324471], 750m, $22-$ 28.vi.1980,, , CNCD 14005, Wood \& Lafontaine (CNC). Rampart House, [67.421455, -140.983336], 18.vii.1951, , CNCD 13981, C.C. Loan (CNC). Old Crow, [67.571219, -139.833877], 2.vii.1983, +, JSS 20138, R.A. Cannings (UBCZ). British Mountains, Firth River, [68.848549, -140.48328], 24.vii.1956, \&, CNCD 14053, R.E. Leech (CNC); 24.vi.1984, +, JSS 18367, S.G. Cannings (CNC). Kluane; Ruby Ranges; Pika Camp, [16.vi.2004 23.vi.2004, +, JSS 25586, E.S. Bakker (WVSC). United States of America: Alaska: ANCHORAGE Co.: Anchorage, [61.175333, -149.861715], 13.vi.1921, + , JSS 19547, J.M. Aldrich (CNC). MATANUSKA-SuSITNA Co.: Matanuska, [61.541945, -149.229674], 4.vi.1944, + , JSS 19557, 10.vi.1944, + , JSS 19537, 11.vi.1944, $q$, JSS 19536, 17.vi.1944, $q$, JSS 19538, 1.vi.1945, 2 \%, JSS 19535, 19539, J.C. Chamberlin (CNC). Trapper Creek, 36 miles North of Willow, [62.31666667, -150.2166667], 19.vii.1984, CNCD 60064, S. \& J. Peck (CNC). Unalakleet, [63.86666667, -160.7833333], 17.vi.1961, $q$, CNCD 26575, B.S. Heming (CNC); 16.viii.1961, 2 , CNCD 26577, 26578, R. Madge (CNC). Southeast FAIRBAnKs Co.: Big Delta, Lake Boleo, [64.154432, 145.836524], 19.v.1951, , CNCD 26553, W.R.M. Mason (CNC). NOME AREA: Mile 55 of Kougarok Road, [65.08972222, -164.6722222], 20-26.vi.2005, +, CNCD 30893, J.\&R. Skevington (CNC); Nome Area, Mile 17 of Kougarok Road, [64.70611111, -165.2972222], 21-23.vi.2005, 2q, CNCD 30881, 30902, 26-28.vi.2005, 2q, CNCD 30895, 30897, 30898, J.\&R. Skevington (CNC). Colorado: Chambers Lake, [40.603663, -105.853645], 3.viii.1932, + , JSS 20714, Chas L. Fluke (CSUC). Idaho: Keene Valley, [44.18333333, -73.78333333], 25.v.1910, JSS 21351, H. Notman (MCZ). Maine: Bar Harbor, [44.38333333, -68.2], ๆ, JSS 21348, (MCZ). FrANKLIN Co.: Dryden, [44.586729, -70.209783], 20.vii.1959, ${ }^{\lambda}$, CNCD 26734, G.H. Heinrich (CNC). Massachusetts: HAMPSHIRE CO.: [42.335786, -72.644117], .vi.1922, ô, CNCD 26739, P.A. Readio (CNC). MIDDLESEX Co.: Melrose Highlands, [42.470929, -71.061441], 16.vi.1911, J, CNCD 26740, J.D. Tothill (CNC). Michigan: Manistee Lake, [44.24749, -86.30471], 22.v.1955, đ̂, JSS 21138, R.W. Hodges (MSUC). Sagola, [46.09028, 88.0775], 6.vi.1983, + , JSS 21136, M. Arduser (MSUC). Isle Royale, [48, -88.83333333], 3.vii.1957, +, JSS

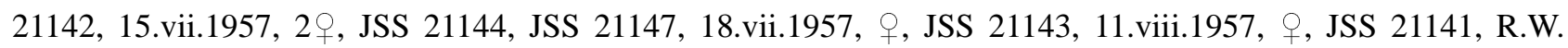
Hodges (MSUC). KALKASKA Co.:14.vi.1949, + , JSS 21139, R.R. Dreisbach (MSUC); 12.vi.,, , JSS 21140, R.R. Dreisbach (MSUC). ChIPPEWA Co.: 3.vi.1957, 2q, JSS 21145, 21146, R. \& K. Dreisbach (MSUC). Clare Co.:16.v.1951, + , JSS 21119, 23.v.1959, 2早, JSS 21148, 21149, R. Dreisbach (MSUC). New Hampshire: Franconia, Rt.3 Fanconia North, [44.209935, -71.685178], 20-21.vi.1972, +, USNM ENT 258066, B.J. \& F.C. Thompson (USNM). Pittsburg, Rt.3 Connecticut Lakes, [45.104264, -71.259207], 22-24.vi.1972, 4ㅇ, USNM ENT 258067-258070, B.J. \& F.C. Thompson (USNM). CHESHIRE Co.: Jaffrey, [42.814957, -72.022399], 1941, ภ̂, CNCD 26741, C.W. Johnson (CNC). Bretton Woods, [44.25, -71.43333333], 27.vi., §̂, CNCD 26742, C.W. Johnson (CNC). Coos Co.: Mount Washington, [44.270481, -71.30255], 6.vii., ô, CNCD 26735, (CNC). Lancaster Mt. Prospect, [44.449317, -71.570888], 625m, 19.vi.1982, \&, JSS 20780, J.R. Vockeroth (CNC). New Mexico: Lincoln Co.: Sierra Blanca, [33.478065, -105.552907], 2957m, 10-26.vi.1979, ㅇ, JSS 18336, S. \& J. Peck (CNC). New York: UlSTER Co.: Oliverea, [42.065369, -74.460152], 18.vi.1918, §, CNCD 26745, (CNC). Maplecrest, Catskill Mts., [42.275919, -74.186809], 18.vi.1927, JSS 19255, F.M. Schott (FMNH). ESSEX Co.: Heart Lake, Mount Jo, [44.182434, -73.966816], 13.vi.1935, Ĵ, CNCD 26743, C.W. Johnson (CNC). North Carolina: Shining Rock Wild. Area, [35.355, -82.84388889], 23.v.1993, + , JSS 20807, Kondratieff \& Kirchner (CSUC). Pisgah National Forest, 10km SE Linville on Road, [36, -81.8], 760m, 25.v.1999, , JSS 20988, M.I. Erwin (MHPC). 13km W Boone on Blue Ridge Pkwy, [36.233333333, -81.51666667], 1050m, 24.v.1999, 9 , JSS 20987, 25.v.1999, đ̃ JSS 20983, M.I. Erwin (MHPC). Pennsylvania: Black Moshannon State Park, [40.896041, 78.044398], 13.v.1990, ${ }^{\lambda}$, USNM ENT 258081, FC Thompspn (USNM). CENTRE Co., Bear Meadows Natural Area, 11.v.1983, 今, CNCD 5458, F.C. Thompson (USNM). Utah: CACHE Co., Tony Grove Crk, [41.892197, 111.634869], 8-15.vii.1994, +, JSS 24642, W.J. Hanson (EMUS). Vermont: ESSEX Co.: 5 Miles West of Bloomfield, [44.753513, -71.727243], 28.vi.1972, 2 , JSS 18338, 18339, H.J. Teskey (CNC). Virginia: SMYTH Co., Hurricane Creek, 22.v.1981, Ĵ, CNCD 5456, F.C. \& B.J. Thompson (USNM). West Virginia: Standard, off I77, [38.136111, -81.400556], 6.v.2005, , JSS 20692, B. Kondratieff, R. Zuelig, R.F. Kirchner (CSUC). 


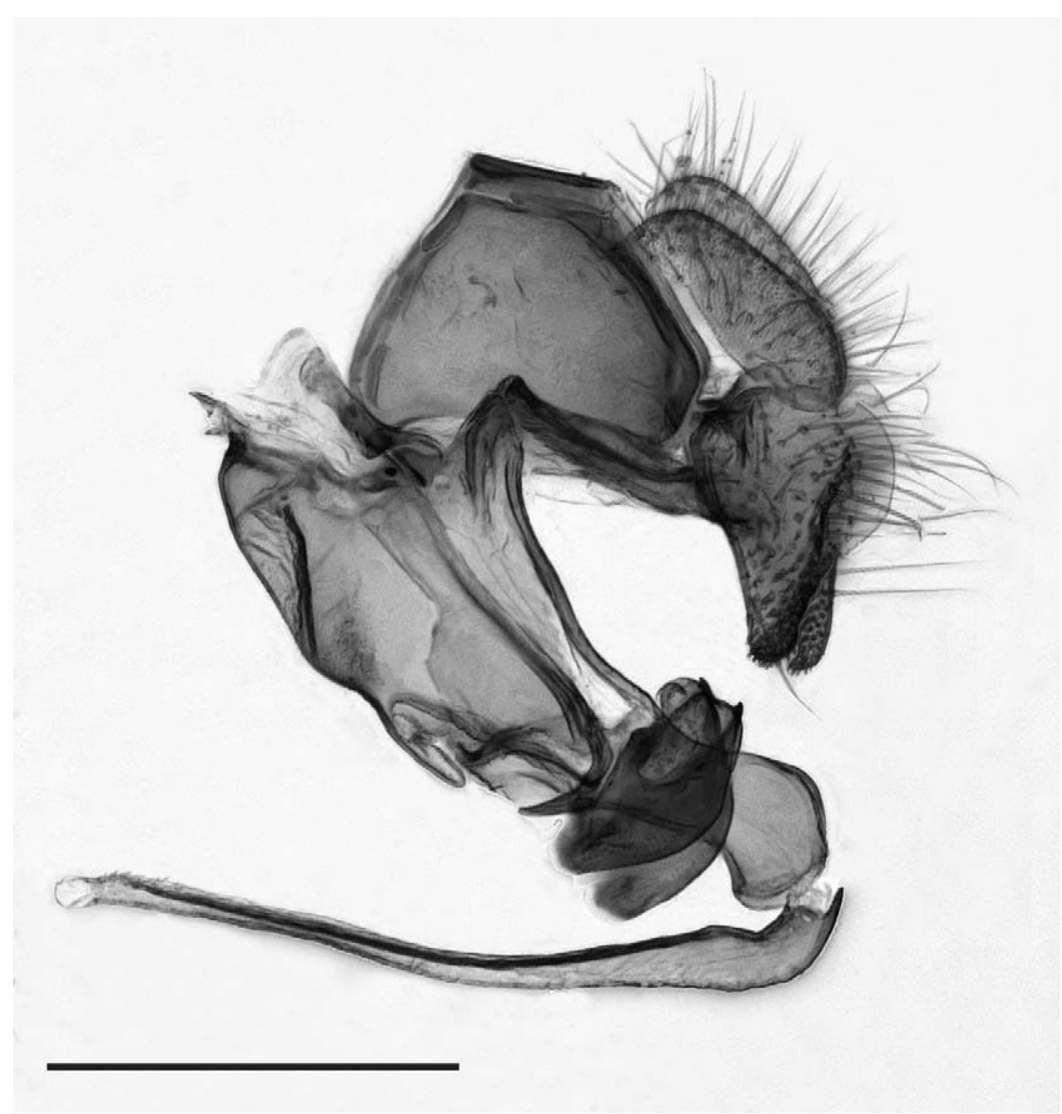

FIGURE 19. Dasysyrphus albostriatus lateral view of male (CNCD 26311) genitalia. Scale bar $=500 \mu \mathrm{m}$.

\section{Discussion}

Nearctic Dasysyrphus show low rates of intraspecific genetic variation for COI (Table 2). Almost all species (74\%) have a maximum intraspecific variation of less than $1 \%$. Where the intraspecific variation is higher, it is likely that cryptic species still exist. In terms of interspecific variation, seven species have a $>2 \%$ genetic divergence from their nearest neighbour (Table 2). This $2 \%$, or greater, difference between species was found to exist in more than 98\% of animal species pairs examined by Hebert et al. (2003) but was likely biased upward as their work was not revisionary. Twelve species of Nearctic Dasysyrphus have <2\% genetic divergence from their nearest neighbour, with the majority of those being less than $1 \%$ (Table 2). Even though low divergence values exist for many species, there is still strong evidence for the species concepts proposed above.

Nearctic Dasysyrphus pauxillus s.l. is here split into four species with two names being resurrected from synonymy (D. laticaudus and D. pacificus) and one species being recognized in this region that was previously only known from the Palaearctic (D. nigricornis). Dasysyrphus laticaudus, D. pacificus and D. pauxillus form a clade as expected; however, D. nigricornis is not directly related (Figs $2 \& 3$ ). All four of these species have an intraspecific variation value below $0.5 \%$ (Table 2). Dasysyrphus nigricornis and D. occidualis have essentially identical COI sequences. They both have low mean intraspecific variation $(0.31 \%$ and $0.11 \%$ respectively) and they are both each other's nearest neighbour with a distance to the nearest neighbour of $0 \%$.

Further investigation should be done into the taxonomy of $D$. bilineatus. This Palaearctic/Oriental species shows great variation in size. It has a maximum intraspecific variation of $0.93 \%$, which is higher than the maximum intraspecific variation of most other species (ignoring the putative intrudens, lotus and venustus complexes; Table 2). However, at just below $1 \%$, this may just be a species with high intraspecific variation. This species falls beyond the scope of this paper and too few specimens were available for both morphological and genetic study to draw more compelling conclusions. 


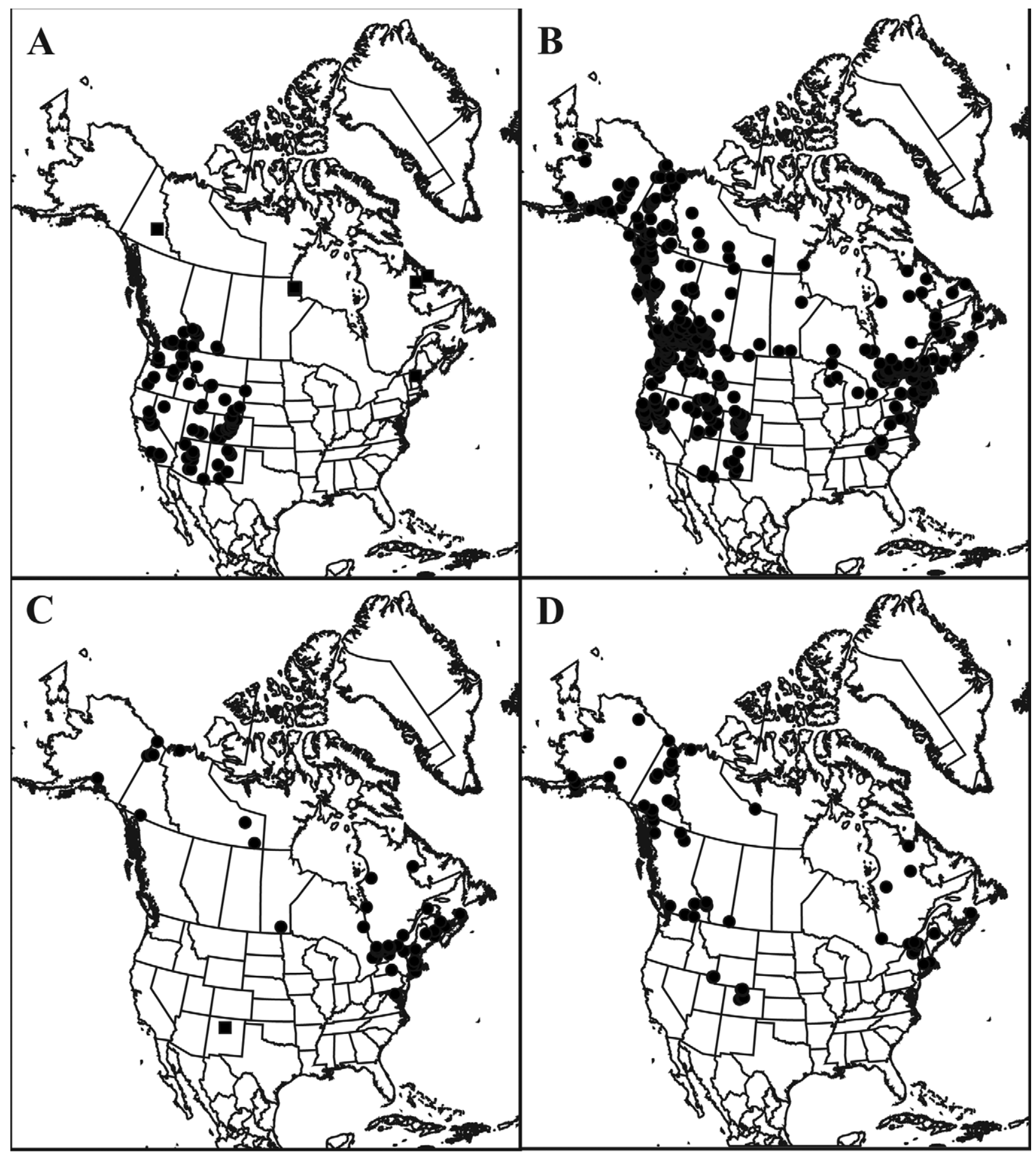

FIGURE 20. Dasysyrphus species range maps (symbols indicate specimen point data). A: D. amalopis (squares) and D. creper (circles); B D. intrudens complex; C: D. laticaudus (circles) and D. richardi (squares); D: D. limatus.

In this study, the intrudens complex is split from venustus. Vockeroth synonymized the intrudens complex under venustus in 1986, treating it as a morphologically variable group. It is difficult to delimit the boundaries of species in venustus sensu Vockeroth. Genitalia are extremely similar in all specimens of the intrudens complex and venustus, even though you can identify venustus by the more straight abdominal maculae, as outlined above. Within the intrudens complex, no congruent patterns exist between morphology, COI, ecology and traditional distribution patterns. Morphological traits often vary more within a genetic cluster than between clusters. There is some congruence between COI data and putative species range, with clusters representing typical cordilleran, boreal or Carolinian species patterns; however, none of these putative taxa are supported morphologically. More 
intense work needs to focus on this group to attempt to resolve the true nature of the species and their relations. If more DNA regions are examined they may provide evidence that shows a clearer pattern. With COI providing so few molecular synapomorphies to support Dasysyrphus species concepts it is not surprising that more rapidly evolving markers are required to help sort out this remaining complex of species. Perceived morphological variation will undoubtedly be minimized when more rapidly evolving genes are applied to the problem. It would be interesting to study how species of Dasysyrphus that are so similar perceive each other and maintain reproductive isolation.

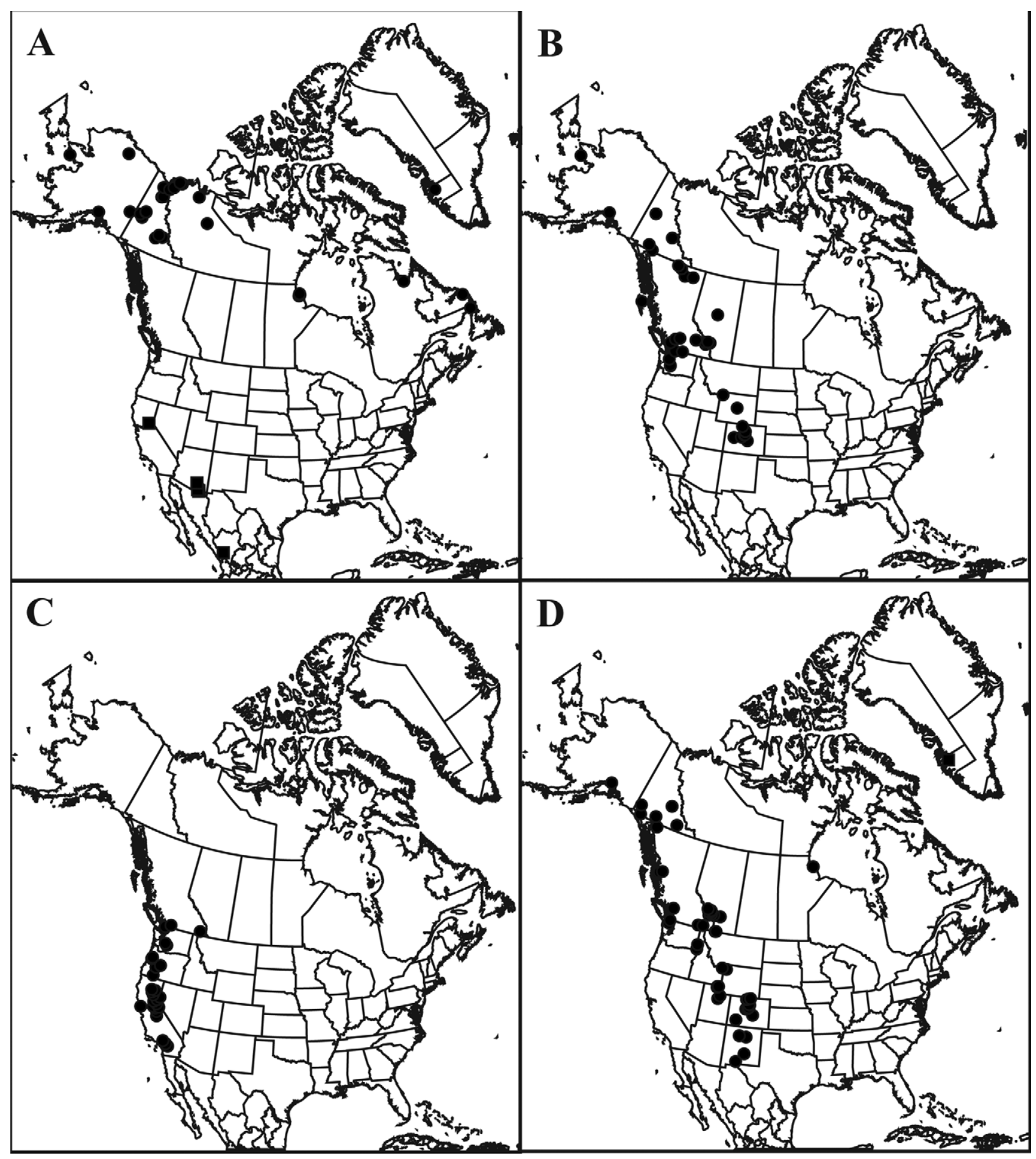

FIGURE 21. Dasysyrphus species range maps (symbols indicate specimen point data). A: D. lotus (squares) and D. nigricornis (circles); B: D. occidualis; C: D. pacificus; D: D. pauxillus (circles) and D. pinastri (squares). 


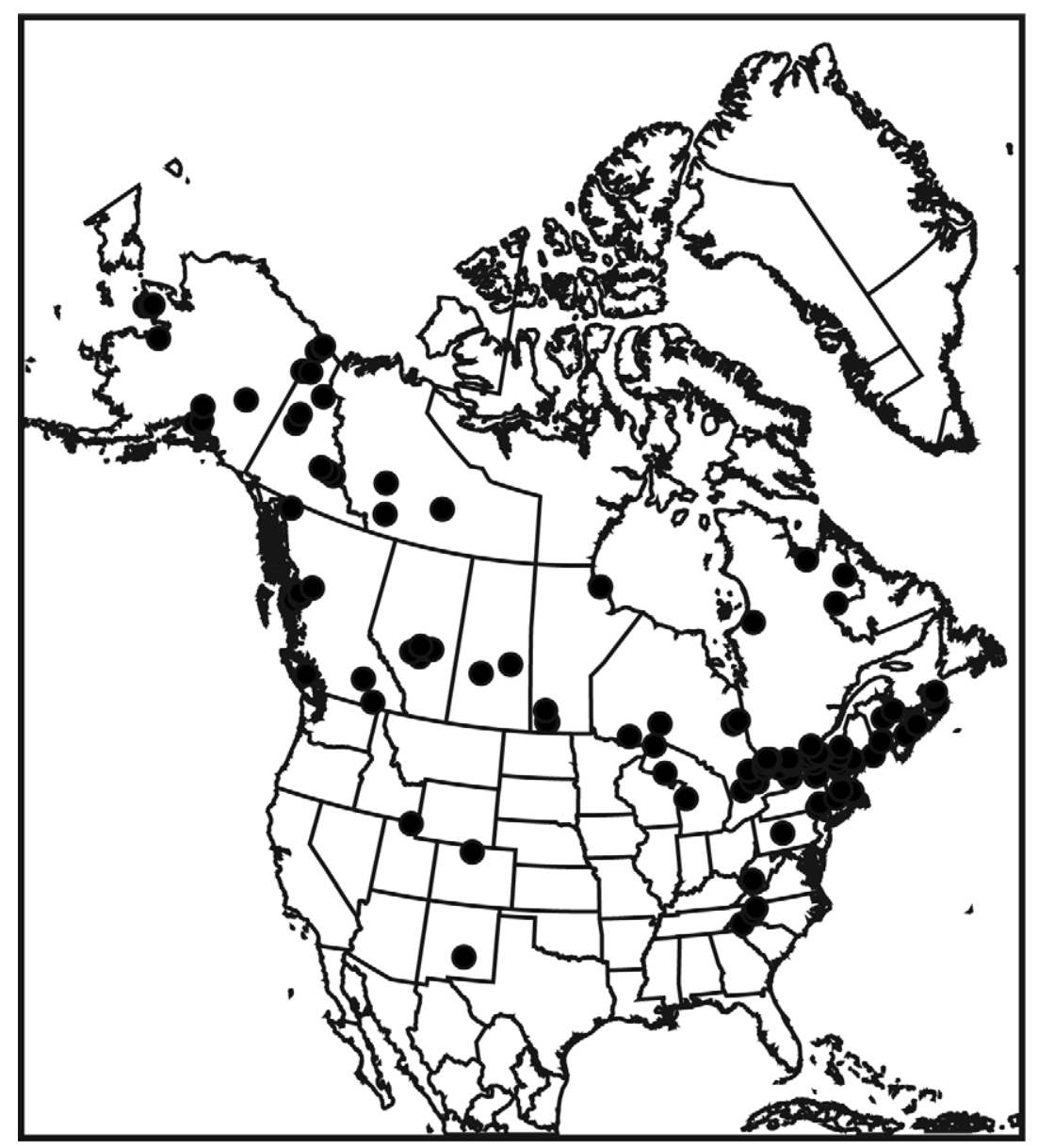

FIGURE 22. Dasysyrphus venustus range map (circles indicate specimen point data).

Vockeroth (1969) pointed out, based on morphology, that Dasysyrphus is one of several groups of syrphines with low interspecific variation and that species were difficult to distinguish. He noted that they tend to have low variation in characters like abdominal colour pattern, shape and size, thoracic colour, head shape and face colour, antennal shape, wing shape, hair characters and structure of male genitalia. Not surprisingly, we now see that their COI sequences show low interspecific variation as well. This low interspecific variation makes delimiting species a difficult task. In the case of pauxillus and allies, COI helped to clarify the distinctions between species. However, in the case of the intrudens complex it has been of no use. Although some progress has been made, such as separating the intrudens complex from venustus, this group still needs work. Despite a failure to resolve the intrudens group problem, bringing new data to Dasysyrphus has clarified most species concepts and should allow research on species in the genus to move forward. Of course, more work may simply show that intrudens is a single variable species, but this hypothesis needs to be tested further because of the unprecedented level of variability within the taxon.

A total evidence approach was useful in delimiting species of Dasysyrphus. Neither COI nor morphology alone was able to resolve all species. Dasysyrphus nigricornis and D. occidualis had identical barcodes and would not have been distinguished if not for morphology. Likewise, sorting the pauxillus sensu Vockeroth specimens based on morphology alone would likely have not resulted in the same degree of delimitation due to their extremely similar habitus and very few and subtle differences. More work is needed on the intrudens complex but in the interim we hope that our work will stabilize taxonomy within Nearctic Dasysyrphus and provide the impetus for future work on larval ecology, pollination and other applied fields. 


\section{Acknowledgements}

We are indebted to Chris Thompson for his guidance with this project. Thank you to the insect collection managers who graciously provided specimens for study. Also to E. Proctor, P. Laska, T. Nielsen, W. van Steenis, M. Hauser for specimens. Thanks to S. Kelso for his guidance in the molecular lab, to W. Knee for his help with the Bayesian analysis, to D. Doczkal for advice on Dasysyrphus. We would like to thank V. Davydov for the photograph of the Dasysyrphus larva (Fig. 1A) and A. Young for the photograph of the adult (Fig. 1B). Agriculture and Agri-Food Canada for provided the resources and equipment required to complete this project and the Biodiversity Institute on Ontario provided DNA barcoding support. Funding support was provided by grants to J.H. Skevington (NSERCCANPOLIN, NSERC Discovery, and Agriculture and Agri-Food Canada) and scholarships to M.M. Locke (Carleton University Faculty of Graduate Studies and Research Travel Bursaries). This is CANPOLIN publication \# 71.

\section{References}

American Museum of Natural History (2005) AMNH Invertebrate Zoology Type Specimens Database. Available from http:// research.amnh.org/iz/types_db/ (Accessed 27 February 2012)

Bagatshanova, A.K. (1980) New species of Syrphidae (Diptera) from Central Yakutia. Entomologitsheskoe Obrozenie, 59, $421-427$.

Barkalov, A.V. (2007) Hoverflies of the genus Dasysyrphus Enderlein, 1937 (Diptera, Syrphidae) from the Urals, Siberia and the Far East. Euroasian Entomological Journal, 6, 273-298.

Bartsch, H., Binkiewicz, E., Råden, A. \& Nasibov, E. (2009) Nationalnyckeln till Sveriges flora och fauna. Tvåvingar: Blomflugor: Syrphinae. Diptera: Syrphidae: Syrphinae. ArtDatabanken, SLU, Uppsala, 406 pp.

Becker, T. (1921) Neue Dipteren meiner Sammlung. I. Syrphidae. Mitteilungen aus dem Zoologischen Museum in Berlin, 10, $1-93$.

Beckemeyer, R.J. (2009) Samuel Wendell Williston - The first and foremost Kansas dipterist. Transactions of the Kansas Academy of Science, 112(4), 225-228. http://dx.doi.org/10.1660/062.112.0412

Bicik, V. \& Laska, P. (1996) Revision of type material of Scaeva obscura Zetterstedt, 1838 (Diptera, Syrphidae). Acta universitatis Palackianae Olomucensis Facultas Rerum Naturalium Biologica, 33, 7-14.

Brouillet, L., Coursol, F., Meades, S.J., Favreau, M., Anions, M., Bélisle, P. \& Desmet, P. (2010) VASCAN, the Database of Vascular Plants of Canada. Available from http://data.canadensys.net/vascan/ (Accessed 1 May 2012).

Brown, R.W. (1956) Composition of Scientific Words. Smithsonian Institution Press, Washington, D.C., 882 pp.

Byers, G.W., Blank, F., Hanson, W.J., Beneway, D.F. \& Fredrichson, R.W. (1962) Catalogue of they types in the Snow Entomological Museum. Part III (Diptera). University of Kansas Science Bulletin, 43, 131-181.

Cole, F.R. \& Lovett, A.L. (1919) New Oregon Diptera. Proceedings of the California Academy of Sciences, 9, 221-255.

Cumming, J.M. \& Wood, D.M. (2009) Adult morphology and terminology. In: Manual of Central American Diptera. NRC Research Press, Ottawa, Ontario, Canada.

Curran, C.H. (1921) A revision of Syrphus species belonging to the ribesii group (Dipt.). The Canadian Entomologist, 53(7) $152-160$. http://dx.doi.org/10.4039/Ent53152-7

Curran, C.H. (1925) Contribution to a Monograph of the American Syrphidae from North of Mexico. Bulletin of the University of Kansas - Science Bulletin, XV, 1-283.

De Geer, C. (1776) Mémoires pour servir à l'histoire des Insects. Hosselberg, Stockholm, Sweden, 523 pp.

Doczkal, D. (1996) Hoverflies from Germany: first records and little known species (Diptera, Syrphidae). Volucella, 2, 36-62.

Dusek, J. \& Laska, P. (1967) Versuch zum aufbau eines Natürlichen Systems mitteleuropäischer Arten der Unterfamilie Syrphinae (Diptera). Acta scientiarum naturalium Academiae bohemoslovacae Brno, 1, 349-390.

Dusek, J. \& Laska, P. (1969) Scaeva arcuata Fallen, 1817 (Insecta, Diptera): Proposed suppression of the specific name under the plenary powers. Z.N.(S.) 1885. Bulletin of Zoological Nomenclature, 26, 171-173.

Dusek, J. \& Laska, P. (1974) Influence of temperature during pupal development on the colour of syrphid adults (Syrphidae, Diptera). Folia Facultatis Scientiarum Naturalium Universitatis Purkyninae Bruennsis, 15, 77-81.

Enderlein, G. (1938) Beiträge zur Kenntnis der Syrphiden. Sitzungsberichte der Gesellschaft Naturforschender Freunde Berlin, 1937, 192-237.

Evenhuis, N.L. (2012) Abbreviations for Insect and Spider Collections of the World. http://hbs.bishopmuseum.org/codens/ codens-inst.html (Accessed 3 February 2012).

Fabricius, J.C. (1775) Systema entomologiae, sistens insectorum classes, ordines, genera, species, adiectis synonymis, locis, descriptionibus, observationibus. Kortii, Flensbvrgi et Lipsiae, 832 pp.

Fabricius, J.C. (1805) Systema antliatorum secundum ordines, genera, species. C. Reichard, Brunsvigae, 30 pp.

Fallén, F.C. (1817) Syrphici Sveciae. In: Diptera Sveciae / descripta a Carlo Frederico Fallén. Literis Berlingianis, Lundae, 62 pp. 
Farris, J.S., Albert, V.A., Källersjö, M., Lipscomb, D. \& Kluge, A.G. (1996) Parsimony jackknifing outperforms neighborjoining. Cladistics, 12, 99-124. http://dx.doi.org/10.1111/j.1096-0031.1996.tb00196.x

Flint, O.S.J., Menke, A.S., Thompson, F.C. \& Ward, R.A. (1976) The United States National Entomological Collections. Smithsonian Institution Press, Washington, D.C., 47 pp.

Fluke, C.L. (1933) Revision of the Syrphus flies of America north of Mexico (Diptera, Syrphidae, Syrphus S.L.) Part 1. Transactions of the Wisconsin Academy of Sciences, Arts and Letters, 28, 63-127.

Folmer, O., Black, M., Hoeh, W., Lutz, R. \& Vrijenhoek, R. (1994) DNA primers for amplifcation of mitochondrial cytochrome c oxidase subunit I from diverse metazoan invertebrates. Molecular Marine Biology and Biotechnology, 3, $294-299$.

Frey, R. (1915) Diptera Brachycera aus den arktischen Kustengegenden Sibiriens. Zapiski Imperatorskoi Akademii Nauk, ser. $8,19(10), 35 \mathrm{pp}$.

Frey, R. (1950) Dipterfaunan vid Tana älv i Utsjoki sommaren 1949. Notulae Entomologica, 30, 5-17.

Ghorpade, K. (1994) Diagnostic keys to new and known genera and species of Indian subcontinent Syrphini (Diptera: Syrphidae). Colemania: Insect Biosystematics, 3, 1-15.

Gibson, J.F., Kelso, S., Jackson, M.D., Kits, J.H., Miranda, G.F.G. \& Skevington, J.H. (2011) Diptera-specific polymerase chain reaction amplification primers of use in molecular phylogenic research. Annals of the Entomological Society of America, 104, 976-997. http://dx.doi.org/10.1603/AN10153

Gibson, J.F., Skevington, J.H. \& Kelso, S. (2010) Placement of Conopidae (Diptera) within Schizophora based on mtDNA and nrDNA gene regions. Molecular Phylogenetics and Evolution, 56, 91-103. http://dx.doi.org/10.1016/j.ympev.2010.03.026

Goeldlin de Tiefenau, P. (1974) Contribution a l'etude systematique et ecologique des Syrphidae (Dipt.) de la Suisse occidentale. Mitteilungen der Schweizerischen Entomologischen Gesellschaft, 47, 151-251.

Goffe, E.R. (1944) Some changes in generic nomenclture in Syrphidae (Diptera). Entomologist's Monthly Magazine, 80, 128-132.

Goot, V.S. van der (1960) Zweefvliegvangsten in de Italiaanse Alpen (Diptera, Syrphidae). Entomologische Berichten, 20(6), $105-107$.

Hajibabaei, M., deWaard, J.R., Ivanova, N.V., Ratnasingham, S., Dooh, R.T., Kirk, S.L., Mackie, P.M. \& Hebert, P.D.N. (2005) Critical factors for assembling a high volume of DNA barcodes. Philosophical Transactions of the Royal Society B, 360, 1959-1967. http://dx.doi.org/10.1098/rstb.2005.1727

Hebert, P.D.N., Ratnasingham, S. \& de Waard, J.R. (2003) Barcoding animal life: cytochrome c oxidase subunit 1 divergence among closely related species. Proceedings of the Royal Society B, 270, S96-S99.

Hine, J.S. (1922) Descriptions of Alaskan Diptera of the family Syrphidae. Ohio Journal of Science, 22, 143-147.

Huo, K.-K., Zhang, H.-J. \& Zheng, Z.-M. (2005) Two new species of Dasysyrphus (Diptera, Syrphidae) from China, with a key to species from China. Acta Zootaxonomica Sinica, 30, 847-851.

ICZN: International Commission on Zoological Nomenclature of 1972 (1972) Opinion 978: Scaeve arcuate Fallén, 1817 (Insecta, Diptera): Suppressed under the plenary powers. Bulletin of Zoological Nomenclature, 29, 9-10.

Krpac, V.T., Vujic, A., Simic, S., Radenkovic, S. \& Lazarevska, S. (2009) Revision of the genus Dasysyrphus Enderlein, 1938 (Diptera: Syrphidae) in the fauna of Macedonia. Kragujevac Journal of Science, 31, 103-108.

Linnaeus, C. (1758) Systema naturae. L. Salvii, Holmiae, 10(1), 824 pp.

Maddison, W.P. \& Maddison, D.R. (2010) Mesquite: a modular system for evolutionary analysis Version 2.73 (build 544). Available from http://mesquiteproject.org (accessed 3 February 2012)

Matsumura, S. (1918) New species of the economic Syrphidae of Japan. Journal of the College of Agriculture Hokkaido Imperial University, 8, 1-31.

Matsumura, S. \& Adachi, J. (1917) Synopsis of the economic Syrphidae of Japan (pt. III). The Entomological Magazine, Kyoto, $3,14-46$.

Meigen, J.W. (1822) Systematische Beschreibung der bekannten europaischen zweiflugeligen Insekten. Dritter Theil. SchulzWundermann, Hamm, Germany, 416 pp.

Meijere, J.C.H. de (1914) Studien über südostasiatische Dipteren. IX. Tijdschrift voor Entomologie, 57, 137-276.

Mengual, X., Ståhls, G. \& Rojo, S. (2008) First phylogeny of predatory flower flies (Diptera, Syrphidae, Syrphinae) using mitochondrial COI and nuclear 28S rRNA genes: conflict and congruence with the concurrent tribal classification. Cladistics, 24, 543-562. http://dx.doi.org/10.1111/j.1096-0031.2008.00200.x

Miller, M.A., Pfeiffer, W. \& Schwartz, T. (2010) Creating the CIPRES Science Gateway for inference of large phylogenetic trees. Proceedings of the Gateway Computing Environments Workshop (GCE), 14 Nov. 2010, New Orleans, LA, 1-8.

Mutin, V.A. \& Barkalov, A.V. (1999) Syrphidae. In: Lehr, P.A. (Ed.) Key to the Insects of the Russian Far East. Nauka Publishing House, Leningrad, pp. 655.

Neilsen, T.R. (1998) Hoverflies (Dipt., Syrphidae) in the arctic Pasvik valley, Norway. Fauna Norvegica Series B, 45, 83-92.

Nylander, J.A.A. (2004) MrModeltest v2. Program distributed by the author. Evolutionary Biology Centre, Uppsala University.

Osten Sacken, C.R. (1875) On the North American species of the genus Syrphus (in the narrowest sense). Proceedings of the Boston Society of Natural history, 18, 135-153. 
Osten Sacken, C.R. (1877) Western Diptera: Descriptions of new genera and species of Diptera from the region west of the Mississippi and especially from California. Bulletin of the United States Geological and Geographical Survey of the Territories, 3, 189-354.

Pape, T. \& Thompson, F.C. (2010a) Dasysyrphus Enderlein. Systema Dipterorum, Version 1.0. 44 work records (not peerreviewed material). Available from: http://www.diptera.org/ (Accessed 17 January 2012)

Pape, T. \& Thompson, F.C. (2010b) Dasysyrphus venustus. Systema Dipterorum, Version 1.0.1 work record (not peer-reviewed material). http://www.diptera.org/ (Accessed 15 December 2011)

Peck, L.V. (1974) New species of hover flies (Diptera, Syrphidae) in the Palearctic fauna. Entomologicheskoe Obozrenie, 53 , 903-915.

Peck, L.V. (1988) Family Syrphidae. In: Soos, A. \& Papp, L. (Eds.) Catalogue of Palaearctic Diptera. Vol.8. SyrphidaeConopidae. Akadémiai Kiadó, Budapest, Hungary, 11-230.

Penney, H.D., Hassal, C., Skevington, J.H., Abbott, K.R. \& Sherratt, T.N. (2012) A comparative analysis of the evolution of imperfect mimicry. Nature, 483, 461-464. http://dx.doi.org/10.1038/nature10961

Ratnasingham, S. \& Hebert, P.D.N. (2007) BOLD : The Barcode of Life Data System (www.barcodinglife.org). Molecular Ecology Notes, 7, 355-364.

Reemer, M. (2002) Dasysyrphus lenensis in the Netherlands (Diptera: Syrphidae). Nederlandse Faunistische Mededelingen, 17, 13-18.

Rojo, S., Gilbert, F.S., Marcos-Garcia, M.A., Nieto, J.M. \& Mier, M.P. (2003) A World Review of Predatory Hoverflies (Diptera, Syrhidae: Syrphinae) and Their Prey. CIBIO Ediciones, Alicante, Spain, 348 pp.

Ronquist, F., Huelsenbeck, J. \& Teslenko, M. (2011) Draft MrBayes version 3.2 Manual: Tutorials and Model Summaries. http://mrbayes.sourceforge.net/mb3.2_manual.pdf (2 March 2012).

Rotheray, G.E. (1993) Colour Guide to Hoverfly Larvae (Diptera, Syrphidae). Derek Whiteley, Sheffield, England, 156 pp.

Rotheray, G. \& Gilbert, F. (2011) The Natural History of Hoverflies. Forrest Text, Cardigan, UK, 319 pp.

Schiner, I.R. (1861) Fauna Austriaca. Die Fliegen (Diptera). Wien. Theil I. Heft 3/4, 185-368.

Shorthouse, D.P. (2010) SimpleMappr, an online tool to produce publication-quality point maps. Available from http:// www.simplemappr.net (Accessed 5 January 2012).

Snow, W.A. (1892) Notes and Descriptions of Syrphidae. Kansas University Quarterly, 1, 33-38.

Snow, W.A. (1895) Diptera of Colorado and New Mexico. Kansas University Quarterly, 3, 225-247.

Sorenson, M.D. \& Franzosa, E.A. (2007) TreeRot, version 3. Boston University, Boston, MA. Available from: http:// people.bu.edu/msoren/TreeRot.html (Accessed 2 March 2012)

Speight, M.C.D. (2011) Species accounts of European Syrphidae (Diptera), Glasgow, 2011. Syrph the Net Publications, Dublin, 285 pp.

Stone, A., Sabrosky, C.W., Wirth, W.W., Foote, R.H. \& Coulson, J.R. (1965) A catalog of the Diptera of America north of Mexico. U.S. Dep. Agric. Handb., Washington D.C., 1696 pp.

Stubbs, A.E. \& Falk, S. (2002) British hoverflies: an illustrated identification guide. Second edition. British Entomological and Natural History Society, 469 pp.

Stys, P. \& Moucha, J. (1962) Neue Beobachtungen und taxonomische Bemerkungen zur Syrphidenfauna des TatraNationalparks (Diptera, Syrphidae). Acta Universitatis Carolinae Biollogica, 55-72.

Swofford, D.L. (2003) PAUP*. Phylogenetic Analysis Using Parsimony (*and Other Methods) Version 4.0. Sinauer Associates, Sunderland, MA.

Thompson, F.C. (1999) A key to the genera of the flower flies (Diptera: Syrphidae) of the Neotropical Region including descriptions of new genera and species and a glossary of taxonomic terms. Contributions on Entomology, International, 3, 322-378.

Thompson, F.C. \& Nielsen, T.R. (in press) Synonymic notes on some Palaearctic species of Dasysyrphus Enderlein (Diptera: Syrphidae)

Thompson, F.C. \& Pont, A. (1994) Systematic Database of Musca Names (Diptera). Theses Zoologicae, $20,221$.

USDA, NRCS (2012) The PLANTS Database. National Plant Data Team, Greensboro, NC 27401-4901 USA. Available from http://plants.usda.gov (Accessed 9 January 2012)

van Veen, M.P. (2004) Hoverflies of Northwest Europe: Identification keys to the Syrphidae. KNNV Publishing, Utrecht, The Netherlands, $254 \mathrm{pp}$.

Verrall, G.H. (1873) Additions and correction to the list of British Syrphidae. Entmologist's Monthly Magazine, 9, 251-256, 281-286.

Violovitsh, N.A. (1975) Some new species of hover-flies (Diptera, Syrphidae) from the fauna of the USSR. Novye I Maloizvestnye Vidy Fauny Sibiri, 9, 73-89.

Vockeroth, J.R. (1969) A revision of the genera of the Syrphini (Diptera: Syrphidae). Memoirs of the Entomological Society of Canada, 62, 1-176. http://dx.doi.org/10.4039/entm10162fv

Vockeroth, J.R. (1986) Nomenclatural notes on Nearctic Eupeodes (including Metsyrphus) and Dasysyrphus (Diptera: Syrphidae). Canadian Entomologist, 118, 199-204.

http://dx.doi.org/10.4039/Ent118199-3 
Vockeroth, J.R. (1992) The flower flies of the subfamily Syrphinae of Canada, Alaska and Greenland. Canada Communications Group - Publishing, Ottawa, 456 pp.

Wahlberg, N. (2010) The Nymphalidae systematics group-molecular methods. Available from http://nymphalidae.utu.fi/ Nymphalidae/Molecular.htm (Accessed 4 February 2012)

Walker, F. (1852) Diptera. Part III, Insecta Saundersiana: or characters of undescribed insects in the collection of William Wilson Sauders, Esq., Van Voorst, London, 474 pp.

Williston, S.W. (1887) Synopsis of the North American Syrphidae. Bulletin of the United States National Museum, 31, 1-335. http://dx.doi.org/10.5479/si.03629236.31.i

Zetterstedt, J.W. (1838). Dipterologis Scandinaviae. Sect. 3: Diptera. Insecta Lapponica. Lipsiae, Voss, 477-868.

Zetterstedt, J.W. (1843). Diptera Scandinavia disposita et descripta, Officina Lundbergiana, Lundae, 2, 441-894. 